\title{
NOVOS VÍNCULOS JURÍDICOS NAS RELAÇÕES DE FAMÍLIA
}

\author{
Tese de doutorado em Direito (Direito Civil), \\ apresentada ao Departamento de Direito Civil da \\ Faculdade de Direito da Universidade de São Paulo, \\ como requisito parcial para obtenção do título de \\ Doutor, sob a orientação do Prof. Dr. Carlos Alberto \\ Dabus Maluf.
}


NUNES, JOSÉ CARLOS AMORIM DE VILHENA

Novos vínculos jurídicos nas relações de família

Tese de conclusão de curso de Doutorado

FADUSP, São Paulo, 2009, 171 p.

Tese.

Bibliografia.

1. Família 2. Vínculo 3. Entidade familiar 4. Filho 5. Filiação 
CONCEITO FINAL DA BANCA:

1.

ORIENTADOR: PROF. DR. CARLOS ALBERTO DABUS MALUF

2.

3.

4.

5. 
A

Deus,

meus pais,

meus filhos,

à vida. 
Agradeço a todos envolvidos nesse projeto, corpo docente, funcionários e colegas da Faculdade de Direito da Universidade de São Paulo, em especial meu orientador e professores, pela paciência e dedicação ímpares. 


\section{ÍNDICE DO CONTEÚDO}

INTRODUÇÃO. 8

CAPÍTULO I. A FAMÍLIA - NOVOS PARADIGMAS .............................................. 10

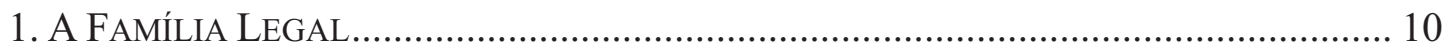

2. Os Princípios de Direito, a Constituição e as RelaÇões de Família ............... 18

2.1. PRINCÍPIO DA DIGNIDADE DA PESSOA HUMANA ……………………………….... 22

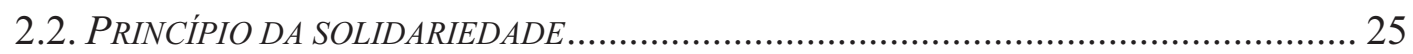

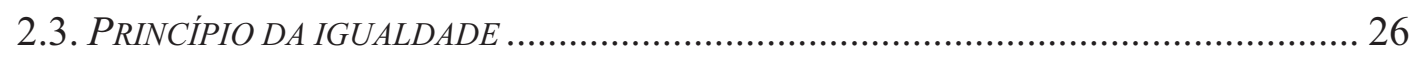

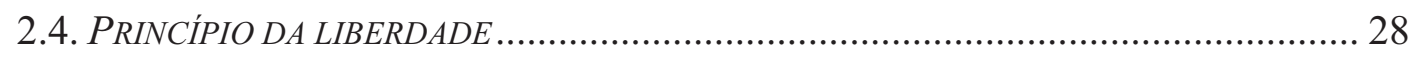

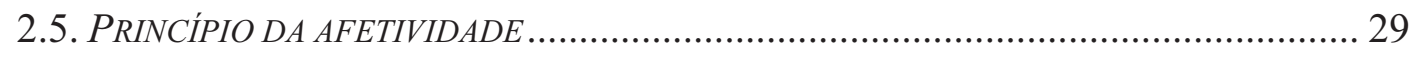

2.6. PRINCÍPIO DA CONVIVÊNCIA FAMILIAR ……………………………………....... 30

2.7. PRINCIPIO DO MELHOR INTERESSE DA CRIANÇA E DO ADOLESCENTE....................... 31

2.8. PRINCÍPIO DA SEGURANÇA JURIDICA ……………………………………......... 32

3. Avanços e Retrocessos do Direito de família na Legislação e na

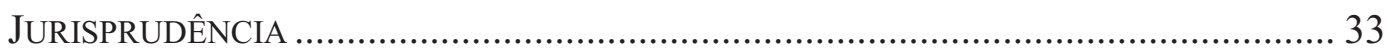

CAPÍTULO II. OS NOVOS VÍNCULOS E AS ENTIDADES FAMILIARES...... 42

1. ENTIDADES FAMILIARES. NoÇ̃̃o …………………………………………...... 42

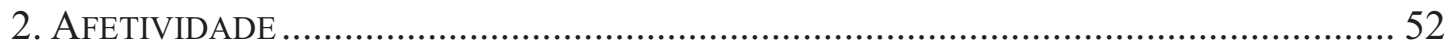

3. DiREITOS-DEVERES: A FUNÇÃo SOCIAL DA FAMÍLIA ……………………………..... 56

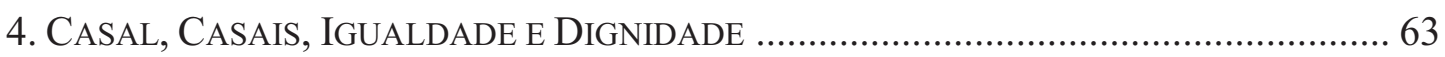

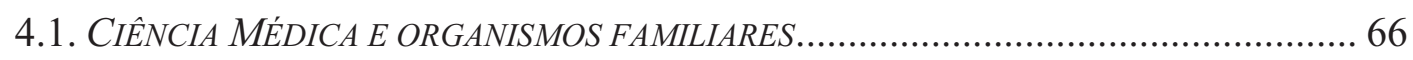

CAPÍTULO III. FILHO - UM NOVO STATUS................................................... 72

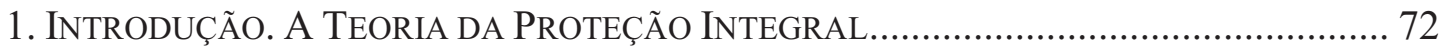

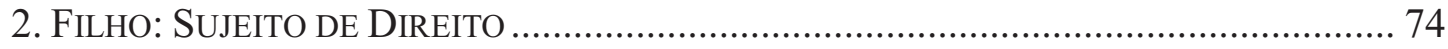

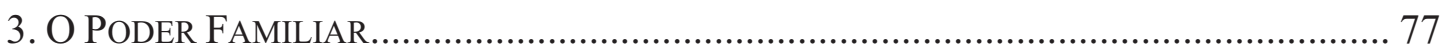

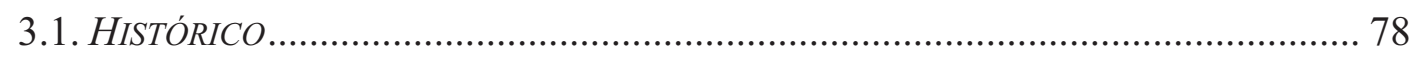

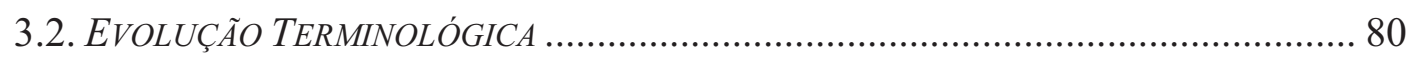

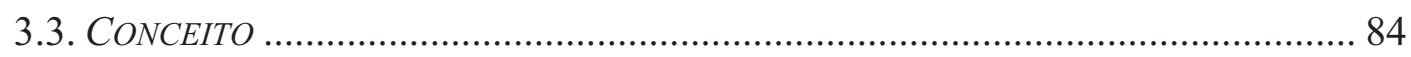

4. FILHOS, IGUALDADE E DIGNIDADE...................................................................... 87 


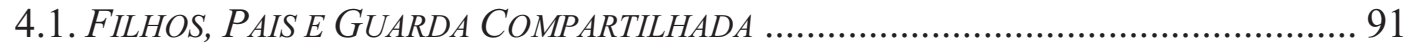

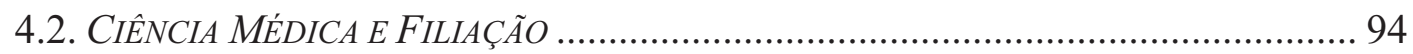

CAPÍTULO IV ......................................................................................................... 97

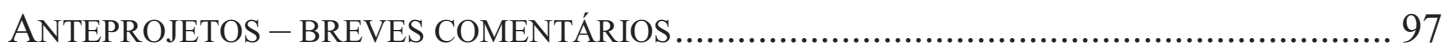

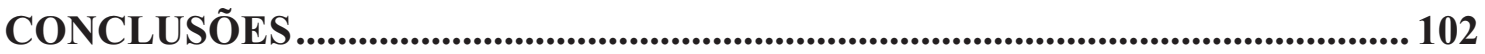

ANEXO A - LEI SOBRE A GUARDA COMPARTILHADA ................................. 109

ANEXO B - ANTEPROJETOS DE LEI SOBRE FAMÍLIA .............................. 111

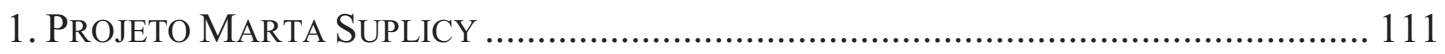

2. Projeto Clodovil Hernandes (antigo Laura Carneiro) ............................... 118

3. ProJeto CÂNDIDO VACCAREZZA …....................................................................... 122

4. Projeto SÉrgio Barradas Carneiro (Estatuto das Famílias) ...................... 138

5. Projeto Walter Brito Neto ........................................................................... 183

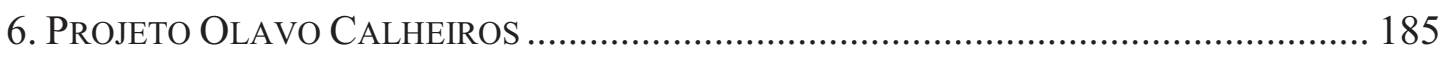

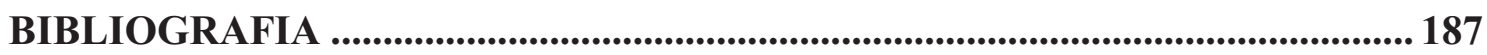

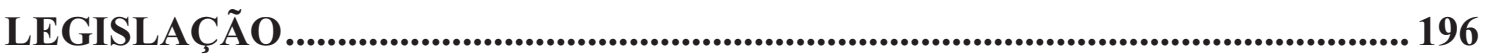

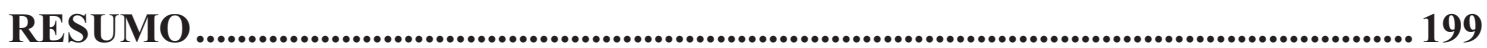

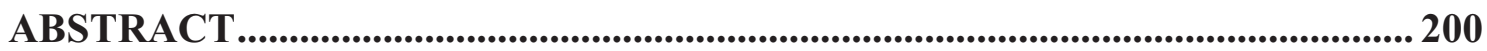

RÉSUMÉ 


\section{INTRODUÇÃO}

A família atual tem sofrido grandes transformações resultantes da mutação social, com graves reflexos nos direitos e deveres dos seus membros, porque a forma de sua constituição, outrora baseada no casamento indissolúvel e na prole então chamada "legítima", cedeu espaço a inúmeras outras, decorrentes de toda uma sorte de convivências alheias ao casamento e da progressiva equalização de direitos entre homem e mulher e entre todos os filhos.

A lei vigente não contempla, de forma explícita, novas modalidades de vínculos familiares ou filiais que não os já nomeados na Constituição de 1988 e no Código Civil.

O problema desse estado de coisas reside em que vários grupos e indivíduos, com base em princípios constitucionais gerais, estão avocando a si o direito de serem considerados como entidades familiares ou como filhos, e parte da doutrina e da jurisprudência vem aceitando essa argumentação de forma ampla e irrestrita, dando guarida a pleitos dessas minorias, todavia no perigoso vácuo criado pela ausência de uma sistematização jurídica prévia que dê estabilidade social a esse movimento.

O objetivo deste trabalho é a análise dos novos vínculos apresentados como legítimos formadores da família contemporânea, e apontar quais deles, dentro da ótica dos princípios constitucionais gerais, do afeto - como elo essencial para a sobrevivência de tal núcleo - e da sociedade democrática, são aptos a formar, no aspecto jurídico, o núcleo familiar, sem que disso resulte a perda de referência da família como "base da sociedade".

Nesse caminho, passaremos pelo estudo da família, enfocando sua formação e extinção, e da filiação, bem como dos princípios de Direito intimamente ligados ao tema, como o da dignidade da pessoa humana, da solidariedade, da afetividade, da igualdade, da liberdade, da convivência familiar e do melhor interesse da criança, bem assim do Estado Democrático de Direito e da função social da família, como meio para o alcance das conclusões sobre esse tema, em contribuição original à ciência jurídica brasileira.

Com esse desiderato, no Capítulo I, principia-se por apresentação da família, núcleo social primário, berço do poder familiar, mostrando suas antiga e nova feições, a força de seus elos e as conseqüências de sua quebra; são analisadas as 
relações familiares em face dos princípios de Direito, da Constituição, da legislação infraconstitucional, da jurisprudência e dos projetos de lei mais expressivos no assunto.

O Capítulo II traz análise dos organismos familiares sob a ótica dos novos paradigmas, sua noção, a importância da afetividade para sua sustentação, a função social da família e os direitos e deveres que emergem desse elo, as diversidades dentro do casal e entre casais, as perplexidades geradas pelas descobertas e intervenções da medicina.

No Capitulo III, prossegue-se com destaque para o novo olhar sobre os filhos e seus pais - todos esses atores com papéis modificados, tanto na família quanto no exercício do poder familiar; os poderes-deveres dos genitores dentro da família, o papel que coube antes e que cabe hoje a cada um dos integrantes do núcleo familiar e o porquê das mudanças ocorridas nas funções desses atores, enfrentando-se a questão do filho agora posto como sujeito de direito, com supedâneo na teoria da proteção integral, bem assim do choque da filiação biológica com a afetiva.

Volta-se atenção, ainda, no Capítulo IV, para o que a sociedade, por seus representantes no Legislativo, vem acenando como soluções possíveis para pacificação dos conflitos atinentes à família, tecendo-se considerações sobre os anteprojetos de lei na matéria.

Encerra-se apresentando Conclusão, em itens, visando apontar caminhos para que a nova (e tão antiga) família, com seus novos (e tão antigos) integrantes, possa continuar a ser recepcionada, não só pela lei, mas também pelo meio social, no lugar de destaque que, desde onde alcança a memória, sempre esteve ela e sempre deverá restar: - "base da sociedade". 


\title{
CAPÍTULO I. A FAMÍLIA - NOVOS PARADIGMAS
}

\author{
1. A FAMÍLIA LEGAL
}

A família tem, como sempre teve, papel primordial na sociedade.

Assim, com igual prioridade, de forma especial, deve o Direito dela ocupar-se, não para amarrá-la, engessá-la ou pô-la numa redoma, mas para reconhecê-la e ampará-la, livre de velhos conceitos e preconceitos, porque nasce ela do fato, antes que da lei. Villaça enfatiza que "ao legislador, ainda que constituinte, não cabe dizer ao povo como deve ele constituir sua família." ${ }^{1}$.

Demonstrando preocupação em frisar não ser a família uma criação da lei, mas sim uma realidade que brota da união livre dos indivíduos, Jean Carbonnier adverte que a família é um fenômeno à base de dados naturais - biológicos, psicológicos, sociológicos -; porém, que tal fenômeno foi modelado pelo Direito, e continua à espera de ser remodelado por uma política legislativa ${ }^{2}$.

E essa espera a que se refere o doutrinador francês parece que está a acontecer de forma global, pois conquanto existam inúmeras disposições internacionais apontando o rumo da família, verdade é que as legislações vão a passo pequeno na direção da elaboração de políticas legislativas eficazes para solução dos problemas que daí decorrem. A respeito, acerbas foram as críticas ao Livro do Direito de Família do então Projeto do novo Código Civil feitas por Junqueira, no artigo "Retrocesso no Direito de Família"3.

O Brasil não é exceção no descompasso existente entre a realidade social e a legislação vigente, valendo mencionar a observação de Georgette Nacarato Nazo sobre o fato de viver o país "uma anomia indesejável", patente a existência de inúmeras anomalias no campo do Direito positivo, sendo que "na esfera do Direito

\footnotetext{
${ }^{1}$ ÁlVARO VILlAÇA AZEVEDO, Comentários ao Código Civil-artigos 1711 a 1783, vol. 19, São Paulo, Saraiva, 2003.

2 "La famille est un phénomène à base de données biologiques, psychologiques, sociologiques - de données naturelles, en somme, que nous livrent des sciences; mais il a été modelé par le droit, et il est toujours en attente d'être remodelé par une politique législative.". La famille, l'enfant, le couple, Droit Civil, t. 2 , $21^{\text {a }}$ ed., Paris, PUF, 2002, p. 7.

${ }^{3}$ ANTONIO JUNQUEIRA DE AZEVEDO, "Retrocesso no Direito de Família", in Revista da Faculdade de Direito da Universidade de São Paulo, vol. 93, 1998, p. 111-114.
} 
de Família e dos Direitos Sociais, particularmente da igualdade de direitos e obrigações do homem e da mulher, continuam a subsistir discriminações injustificadas." ${ }^{4}$.

Por isso, uma nova visão da questão, contemporânea, se faz necessária, pois do lugar onde se examina agora o conceito de família, já não se enxerga mais o conceito clássico, oriundo do Direito romano, em virtude da distância abismal que entre eles se formou.

Ressaltam a tremenda evolução grandes estudiosos do assunto, como Caio Mário da Silva Pereira ${ }^{5}$, Sílvio Rodrigues ${ }^{6}$ e José Reinaldo de Lima Lopes.

Esse último destaca que, embora natural a união de homem e de mulher, isso não significa que a forma como se apresenta essa união, em diferentes povos e diverso tempo, seja idêntica, pois o uso continuado de uma palavra não determina que seu significado permaneça imutável ao longo da História ${ }^{7}$.

Se, nos primórdios da humanidade, a família matriarcal teve seu lugar, sucedida pela patriarcal - que vingou por séculos e ainda deita raízes nos costumes dos povos -, hodiernamente a quase unanimidade das leis a enfoca como alicerce dos agrupamentos sociais, a exemplo da Constituição brasileira que a declara, expressamente, "base da sociedade" (artigo 226, caput, da Constituição Federal).

Nessa ordem de idéias, a lei civil brasileira veio sendo constantemente alterada, primeiramente para valorização da mulher casada, mediante a edição de diplomas legais como a Lei 4121/62 (Estatuto da Mulher Casada) e a Lei 6515/77

\footnotetext{
${ }^{4}$ Igualdade de direitos nas relações familiares: lei e a prática no Brasil, in Cadernos Liberais - Em homenagem a Washington de Barros Monteiro, n. 95, Brasília, Instituto Tancredo Neves, 1990, p. 35.

${ }^{5}$ Reconhecimento de paternidade e seus efeitos, Rio de Janeiro, Forense, 1997.

${ }^{6}$ A posição da mulher no direito vigente e no projetado - Estudos de Direito Civil, São Paulo, RT, 1979.

${ }^{7}$ Pela sua força e interesse, transcreve-se a idéia: "O que não falar da história da família? Nada mais natural, dizem alguns, do que a união de homem e mulher. Sim, mas em termos. Que os homens sejam atraídos pelas mulheres e vice-versa e que desta atração mútua surjam amores e filhos, podese dizer que é uma regularidade da natureza. Mas que o 'casamento' ou o 'matrimônio' sejam por isto mesmo sempre a mesma coisa em toda parte e em todo o tempo é uma afirmação que um historiador não pode fazer. O casamento em Roma, por exemplo, não criava família. A família romana é uma unidade produtiva, os pais de família comandam os outros membros e tornam-se gerentes de um fundo patrimonial. O modelo de família que conhecemos é outro, a família é uma unidade de consumo, não de produção, sobretudo na família operária, um subsistema previdenciário. Da regular união de homem e mulher e do uso continuado da palavra família podemos pensar muita coisa mas temos de estar atentos para o fato de que a continuidade do uso da palavra pode esconder a descontinuidade das práticas.", in O Direito na História - lições introdutórias, São Paulo, Max Limonad, 2000, p. 20-21.
} 
(Lei do Divórcio) e, mais recentemente, para proteger a família surgida fora do casamento, como nos casos da Carta Constitucional de 1988, das Leis 8971/94 e 9278/96 (sobre União estável) e do Código Civil (Lei 10.406/02). Indo mais além, a Lei 11.340/06 (Lei Maria da Penha - para coibir a violência doméstica e familiar contra a mulher), conceitua a família, "para os efeitos desta Lei", como sendo "a comunidade formada por individuos que são ou se consideram aparentados, unidos por laços naturais, por afinidade ou por vontade expressa" (art. 5, inciso II), acrescentando, mais, no $\S$ único do referido dispositivo que "as relações pessoais enunciadas neste artigo independem de orientação sexual".

No campo do exercício do poder familiar, deve ser destacada a recente lei sobre guarda compartilhada - Lei 11.698/08 - que a define como sendo a responsabilização conjunta e o exercício de direitos e deveres do pai e da mãe que não vivam sob o mesmo teto, concernentes ao poder familiar dos filhos comuns.

Mas, pergunta-se, terão sido suficientes, oportunas e adequadas tais modificações legislativas?

Com certeza podemos dizer que não. Rui Geraldo Camargo Viana doutrina que a nova ordem social está conduzindo à "civilização" do casamento e da família, ou seja, esses elementos migram da ordem social, do alcance das normas de Direito Público, passando a formar blocos de interesses individuais soberanos, fora da esfera de intervenção do Estado $^{8}$.

Sem resposta adequada a esse movimento contínuo, o sistema tradicional legal passa a valer-se de micro-sistemas, com proliferação de leis esparsas, como no caso do Estatuto da Mulher Casada, da Lei do Divórcio, da Lei da União Estável, a Lei Maria da Penha e a Lei da Guarda Compartilhada, apenas para repetir as mais importantes já antes mencionadas, entre tantas outras que espocam de tempos em tempos, ao sabor da vontade e conveniência do legislador.

Mas, mesmo ante a constatação de que grassa o conservadorismo nos nossos Legislativo, Executivo e Judiciário, sendo, inquestionavelmente, o casamento, ainda, privilegiado em confronto com os outros meios de união e de constituição da família (bastando, para tanto, comparar o número de artigos dedicados ao casamento

\footnotetext{
${ }^{8}$ A família - in Rui Geraldo Camargo Viana e Rosa Maria de Andrade Nery (org.), Temas Atuais de Direito Civil na Constituição Federal, São Paulo, RT, 2000, p. 18.
} 
e à união estável no Código Civil e os direitos que vêm sendo dados, nos julgados, à viúva e à ex-mulher, em confronto com os reconhecidos à companheira, em situações assemelhadas), a verdade é que "o concubinato é hoje uma realidade social, econômica e jurídica, que a lei não consegue mais desconhecer." .

E, com essa premissa, propõe-se, aqui, o estudo de mecanismos lógicojurídicos que possam atender à citada nova realidade, evitando, de um lado, as conservadoras armadilhas da exacerbada ideologia da família patriarcal e matrimonializada, ainda vigente e, no outro extremo, aquelas outras, contemporâneas, da família global, a abarcar todos os seres humanos.

Essa "família humana" é referida por José da Cruz Policarpo, que argumenta ser ténue a consciência da responsabilidade de todos por todos e de que o Universo é "casa comum", nas suas riquezas e potencialidades, património de toda a humanidade.

Destaca que a afirmação do "destino universal dos bens", feita por João Paulo II, relativiza os direitos das sociedades e dos Estados, porque lhes aumenta a responsabilidade na busca do "bem-comum" universal e esta consciência de unidade de uma só "família humana", acentua o conhecimento da diversidade e da diferença, que devem ser valorizadas e não ignoradas, na busca da harmonia global ${ }^{10}$.

Sérgio Resende de Barros afirma, no tema, consistir o afeto, além de um laço interno (entre familiares), um laço externo (entre as famílias) capaz de compor todas as famílias em uma só humanidade, a "família humana universal"11.

Como lembrado na lição de Sebastião Luiz Amorim e Euclides Benedito de Oliveira, "a atual Carta reconhece, pois, ao lado da família legítima, resultante da união legal pelo casamento, a família de fato, oriunda de união estável (uma das formas de concubinato). Estende-lhe a proteção, não só com relação aos

\footnotetext{
${ }^{9}$ SEBASTIÃO JOSÉ ROQUE, Direito de Família; São Paulo, Ícone, 1994, p. 215.

${ }^{10}$ JOSÉ DA CRUZ POLICARPO. Globalização, último desafio de harmonia, in Revista Vida Católica, $\mathrm{n}^{\mathrm{o}}$ 21, $3^{\mathrm{a}}$ série, ano VII, Lisboa, Setembro/Dezembro de 2005, tópico III, item 17.2, disponível [on line] http://www.patriarcado-lisboa.pt/vidacatolica/vcnum21/3_17_Artigo_Revista ECONOMIA.doc [10-02-09]

${ }^{11}$ Expressão utilizada por SÉRGIO RESENDE DE BARROS em seu artigo "Direitos Humanos $e$ Direito de Familia", disponível [on line] in http://www.srbarros.com.br/ artigos.php?TextID=85 [26-01-2004].
} 
contraentes, como também aos filhos, já que lhes garante iguais direitos e qualificações, proibindo discriminações relativas à origem da filiação." ${ }^{2}$.

Mas a humanidade e, como parte dela, a sociedade brasileira, desejam mais.

Adverte o filósofo contemporâneo francês Luc Ferry que "vivemos, sem tomar consciência nem medir seus efeitos, uma formidável revolução do espírito”, revolução essa capitaneada pela família moderna e pelo casamento por amor - um vínculo tornado, primeiramente, ideal e, por fim, regra das sociedades atuais inovação que alterou profundamente o cotidiano dos indivíduos, deslocando o "sagrado" - antes representado pela "Divindade, hierarquias sociais aristocráticas, Nação, Pátria, ideais revolucionários” - para a própria humanidade, a nova "encarnação" do sagrado ${ }^{13}$.

Esse processo de "civilização", de "privatização", de "sacralização", por que passam a família e o casamento, afastando-se do poder de intervenção do Estado para conquistarem forma livre, de acordo com interesses individuais, é inevitável, embora haja contramarcha de alguns setores, que teimam em legislar sobre assuntos que não deveriam ser objeto de normatização, pelo menos não da forma como atualmente acontece.

Analisando a inquietante questão, Junqueira manifesta temor de que, como sucedeu com o Direito Romano, toda a beleza e toda a força do sistema jurídico brasileiro, em especial o Direito Civil, venha a perder a sua significação para a maior parte das pessoas, "afastando-se, assim, do presente e da vida"14.

A família, todavia, mesmo tendo forma livre e existência natural, necessita seja regrado o complexo de direitos e deveres que dela nasce, para que, a

\footnotetext{
${ }^{12}$ Concubinato, companheiros: novos rumos, in Teresa Arruda Alvim (coord.), Repertório de jurisprudência e doutrina sobre Direito de Família - aspectos constitucionais, civis e processuais, vol. 2, São Paulo, RT, 1995, p. 72-73.

${ }^{13}$ Famílias, amo vocês: política e vida privada na era da globalização, tradução Jorge Bastos, Rio de Janeiro, Objetiva, 2008, p. 20.

${ }^{14}$ ANTONIO JUNQUEIRA DE AZEVEDO lança, mais, a questão: "Irá o Direito Civil, indagamos qual nova Cassandra, caminhar solenemente para a História, para aí permanecer? Ou, em hipótese um pouco melhor perderá ele aquele seu caráter, que nos ensinaram, de Direito comum em relação aos outros ramos do Direito, tornando-se refúgio de especialistas?", in $O$ Direito Civil tende a desaparecer?, Revista dos Tribunais, vol. 472, fev. 1975, p. 15.
} 
par dos elos particulares à união de fato, seja formado vínculo de responsabilidade legal, "indispensável à segurança dos conviventes e de sua prole"15.

Não se deve perder de vista, porém, que se podendo dar apoio legal à voz pública - quando identificada como inafastável e correta em determinado assunto -, não se pode pretender o inverso, a saber, nenhuma lei se torna, só por assim o querer seu criador, vox populi.

Todo cuidado é necessário, dessa forma, na manutenção e/ou reforma do arcabouço jurídico, a processar-se dentro de uma visão política que deve ser mais que simplesmente pragmática.

Mesmo nos pensadores mais abertos ao novo encontramos afirmação da necessidade de defesa dos valores vigentes e tradições, no que de bom e útil neles se contenha, resistindo-se aos apelos fáceis do politicamente correto e dimensionandose "os efeitos de um século de desconstrução sobre a erosão dos valores tradicionais e também sobre a liberação de novos princípios de sentidos" $"$.

As constantes mudanças sociais provocam perplexidades que nos impulsionam em diferentes direções, a mais comum e imediata, própria da natureza humana, no sentido de rejeitá-las, buscando soluções no presente e no passado, sob ótica tradicionalista, fundamentalista; outra, mais lenta, consiste no progressivo entendimento do porquê de tais transformações, com aceitação e incorporação daquelas tidas como razoáveis e aplicáveis àquela determinada sociedade.

Um dos vetores dessas mudanças é o Estado, em diferentes graus de força - conforme assuma papel liberal, intervencionista ou árbitro-regulador -, bem assim os grupos de excluídos que, ao atingirem dimensão insustentável, provocam importantes e inevitáveis transformações, por vezes a custa de sangue. "A isso somase o fenômeno da urbanização em megalópoles, mudanças na tradicional divisão de tarefas e papéis entre sexos, alterações profundas nas relações de família e de vizinhança. $" 17$.

\footnotetext{
${ }^{15}$ ÁLVARO VILLAÇA AZEVEDO, Do concubinato ao casamento de fato, Belém, CEJUP, 1986, p. 13.

${ }^{16}$ Famílias, amo... cit. (nota 13 supra), p. 28.

${ }^{17}$ O Direito na História cit. (nota 7 supra), p. 17.
} 
Delineia-se, a par desses fatores, uma revolução da intimidade, cujos efeitos não podem ser antecipadamente previstos, tendo como sua bandeira e principal arma o sentimento e como sua grande causa a pessoa.

Realização na vida privada, na atualidade, é o verdadeiro e primordial objetivo das pessoas; o afeto, sob suas diversas formas, os laços conjugais, assim amplamente entendidos, os liames paterno-filiais, o trabalho que enriqueça material e espiritualmente, os momentos de felicidade e infelicidade mutuamente vivenciados, todos esses aspectos sobrepõe-se a quaisquer questões de Estado, agora colocado como um auxiliar da vida privada, "um simples instrumento a serviço do brilho e do sucesso da vida das pessoas" $"$.

Devemos, entretanto, saber resistir aos falsos encantos e facilidades trazidos e expostos, de forma exacerbada, pela globalização liberal, que vem pondo por terra um dos pilares de realização democrática - o poder do coletivo, criador, transformador - eis que nos deparamos com um universo totalmente fora de nosso controle, "desprovido de sentido, na dupla acepção do termo: simultaneamente privado de significado e de direção",19, caos ao qual tentamos, sem sucesso, por cobro, mediante utilização dos recursos técnicos postos, em profusão e com custos cada vez mais acessíveis, à nossa disposição.

Entregar-nos, porém, pura e simplesmente à técnica, estatísticas e resultados ditados por computador, significa aceitarmos um processo sem propósito e de objetivo incerto, apartado da necessária consciência coletiva em prol de um ideal, de uma causa comum.

A respeito, de ser lembrado o exemplo da ficção científica (cada vez mais científica e menos ficcional), onde robôs - aos quais o mundo teria sido entregue para guarda - passaram a identificar no homem a razão da degeneração global e, de conseqüência, concluíram que a eliminação da raça humana seria a solução técnica e adequada a questão de como bem cumprir a tarefa de defender o planeta.

Assim também as soluções dos problemas da família não podem ser determinadas puramente por técnicas científicas, como as de mapeamento do DNA (do inglês: deoxyribonucleic acid, em português: ácido desoxirribonucleico,

\footnotetext{
${ }^{18}$ Familias, amo... cit. (nota 13 supra), p. 24.

${ }^{19}$ LUC FERRY, Aprender a Viver: filosofia para os novos tempos, Rio de Janeiro, Objetiva, 2007, p. 240.
} 
responsável pela transmissão das características hereditárias de cada espécie de ser vivo), de inseminação artificial ou de transformação da aparência sexual externa das pessoas, ou por uma ampliação simplista da concepção de direitos humanos (uma vez que já se fala, com seriedade, até sobre direitos "humanos" dos animais).

Aliás, há uma "Resolução dos Direitos dos Animais", proclamada em 27 de janeiro de 1978, na UNESCO, que em seu art. 14, letra "b", reza que "os direitos dos animais devem ser defendidos por leis, como os direitos do homem", e doutrinadores os defendendo, como Peter Singer e Tom Regan. No Brasil, o tema foi recentemente tratado por Heron José de Santana Gordilho, em artigo intitulado "Direito Animal: a legitimidade de ser parte ${ }^{20}$.

O computador de um registro civil não teria a menor dificuldade em aceitar e incluir, como cônjuge, genitor ou filho de uma pessoa, um cão ou um gato, por exemplo.

Mas, por acaso, teria a consciência coletiva acima citada igual facilidade?

Conhecidos são casos recentes de doação de fortunas para animais domésticos ${ }^{21} \mathrm{e}$, na Índia, há notícias de casamentos de cachorros com meninas ${ }^{22}$, com objetivos de purificação.

Essas circunstâncias, conquanto verdadeiras, nos obrigam a aceitá-las como boas e úteis para a sociedade em que vivemos?

A técnica é, na verdade, uma "racionalidade instrumental",23, uma vez que nos indica a melhor maneira de alcançar um objetivo, porém, ela jamais estabelece por si mesma tal objetivo.

Desse modo, não é o fato de haver opiniões técnicas, favoráveis ou não, sobre assuntos como legalização de união homoafetiva; permissão de adoção de crianças por pares homossexuais; permissão de mudança de gênero de sexo no registro civil e seguinte pleito de casamento civil; reconhecimento de constituição de vínculo familiar no fato da pessoa haver habitado por anos a mesma casa da família e

\footnotetext{
${ }^{20}$ PETER SINGER (Practical Ethics, 2nd edition, Cambridge: Cambridge University Press, 1993); TOM REGAN (Jaulas vazias - encarando o desafio dos Direitos Animais, Lugano, São Paulo, 2006); HERON JOSÉ DE SANTANA GORDILHO, "Direito Animal: a legitimidade de ser parte", Jornal Carta Forense, São Paulo, ed. 70, mar. 2009, p. 32-33.

${ }^{21} \mathrm{http} / / /$ noticias.terra.com.br/popular/interna/0,,OI279429-EI1141,00.html, [04/02/09].

${ }^{22} \mathrm{http}: / /$ www.terra.com.br/istoe/1608/1608semana_2.htm, [04/02/09].

${ }^{23}$ Aprender... cit. (nota 19 supra), p. 248.
} 
dela ter recebido apoio, respeito e consideração; imposição de deveres familiares a quem tenha se utilizado indevidamente de gametas doados para fertilizações destituídas de base familiar que as justifique; que resolve a questão sobre estar a sociedade apta, pronta e disposta a acolher, em caráter de normalidade (no sentido de norma jurídica), tais situações.

Em voto na Corte Suprema da Argentina, o juiz Boggiano, em processo envolvendo pedido da parte autodenominada "Comunidade Homossexual Argentina", argumenta, em contraposição ao de a luta contra a discriminação encerrar um lado moral positivo, que "poder-se-ia chegar a uma situação na qual tantas minorias reclamassem tolerância que já não poderia existir nenhuma maioria. A democracia requer um substrato de valores comuns. E a desintegração desses valores pode conduzir à erosão da coesão da sociedade"24.

É sobre esses ao mesmo tempo difíceis e fascinantes temas que passaremos a tratar, utilizando-nos, sem renegar o necessário uso combinado do pragmatismo e do humanismo, de uma visão filosófica mais ampla em espectro, pois que é a sociedade igualmente ampla na sua formação, certo que os princípios democráticos devem ser, sempre, intimamente ligados à noção de maioria, sendo essa, no fim das contas, quem dita as regras, a começar das Cartas Constitucionais, conforme ensina Bobbio, ao afirmar que "o único modo de se chegar a um acordo quando se fala de democracia, entendida como contraposta a todas as formas de governo autocrático, é o de considerá-la caracterizada por um conjunto de regras (primárias ou fundamentais) que estabelecem quem está autorizado a tomar as decisões coletivas e com quais procedimentos" ${ }^{25}$.

\section{Os PRINCÍPIOS DE DiREITO, A CONSTITUIÇÃo E As RELAÇÕES DE FAMÍlia}

O sistema organizacional e hierárquico da família, assim como o exercício do poder familiar, foram profundamente alterados, sendo seguro e

\footnotetext{
${ }^{24}$ CSJN, “Comunidad Homosexual Argentina”, L. L. 1991-E-679.

${ }^{25}$ NORBERTO BOBBIO, O Futuro da Democracia; uma defesa das regras do jogo, Rio de Janeiro, Paz e Terra, 1986, p. 18.
} 
relevante afirmar, na esteira do pensamento de Orlando Gomes ${ }^{26}$, terem dado lugar a uma nova aliança, fundada sobre o sentimento de mútuo afeto.

Assim é que, no despertar de um novo século, a família desempenha, cada vez mais, papel primordial na formação do indivíduo que, do seu seio, deve partir apto a ser célula independente que gerará novo núcleo natural e fundamental da sociedade $^{27}$, sadio e producente.

Desde a metade do século passado, quando se multiplicaram as formas aceitas de relacionamento sexual dos indivíduos e os meios de constituição e desconstituição dos relacionamentos - a começar pela instituição do divórcio em vários países, passando pela solidificação da família monoparental (inclusive a originada de inseminação artificial) e mesmo regulamentando-se, agora, agrupamentos que tem como núcleo pessoas do mesmo sexo -, o Direito de Família vêm sofrendo constantes adaptações e modificações, premidas pelo choque de anseios dos tradicionais e novos segmentos sociais, como ressalta Georgette Nacarato Nazo ao discorrer sobre a igualdade de direitos nas relações familiares ${ }^{28}$.

A partir de 2001, a Holanda permite o casamento civil de pessoas do mesmo sexo, sendo seguida por Bélgica, Espanha, Canadá, porção dos Estados Unidos (Massachusetts e Connecticut) e Inglaterra, onde legislação com esse objetivo foi aprovada em 05 de dezembro de 2005, a qual foi dada ampla visibilidade por Sir Elton John, conhecido artista inglês que fez questão de manifestar publicamente sua intenção de ser dos primeiros a exercer o direito à nova modalidade de união legal. Com denominações de "união de fato", "união civil”, "parceria", "parceria registrada", "convivência registrada", entre outras, há leis similares, com diversas nuances (como, por exemplo, impedimento à adoção), em Portugal, França, Alemanha, Hungria, Suíça, Dinamarca, Suécia, Noruega, Islândia, Austrália, Nova

\footnotetext{
${ }^{26}$ Direito de Família, $14^{\mathrm{a}}$ ed., atualizada por Humberto Theodoro Júnior, Rio de Janeiro, Forense, 2002.

${ }^{27}$ Nos termos do artigo XVI, n.3, da Declaração Universal dos Direitos Humanos da Organização das Nações Unidas, de 1948, "a família é o núcleo natural e fundamental da sociedade e tem direito à proteção da sociedade e do Estado.".

${ }^{28}$ Igualdade cit. (nota 4 supra) p. 35-36.
} 
Zelândia, África do Sul, porção dos Estados Unidos (New Jersey e Vermont) e, no continente sul-americano, a Argentina ${ }^{29}$.

Nessa medida, no interesse da preservação dos vínculos de família, os direitos e deveres das pessoas que, nesse ambiente, interagem e as formas de serem exercidos tornam-se temas de sumo interesse jurídico, devendo ser objeto de profunda reflexão e pesquisa quanto à maneira de solução dos conflitos deles gerados.

Dentro do contexto constitucional de 1988, foram deixados de lado vários conceitos já não apropriados à realidade vigente, prevalecendo outros, inspirados na Constituição de Weimar, entre eles o da igualdade entre homem e mulher e entre filhos, nos vários campos do Direito ${ }^{30}$.

Passados dois séculos do ideal revolucionário francês (liberdade, igualdade e fraternidade), a Constituição brasileira elegeu a liberdade, a justiça e a solidariedade como objetivos maiores, no intuito de se alcançar a plena realização da sociedade (art. $3^{\circ}, \mathrm{I}$, da $\mathrm{CF}$ ) e tais devem ser norte na aplicação do Direito rumo à concreção dos valores da família.

Emergem, a plena força, os princípios constitucionais, lembrados em primeiro plano pelos doutrinadores contemporâneos, no grupo dos fundamentais, os da dignidade da pessoa humana e da solidariedade, sendo colocados, na categoria dos princípios gerais, os da igualdade (visto em conjunto com o direito à diferença), da liberdade, da afetividade, da convivência familiar e do melhor interesse da criança ${ }^{31}$, aos quais se acrescenta, sem distinção por grupos, o do pluralismo das entidades familiares (esse tido por alguns como princípio específico), o da proteção integral a crianças, adolescentes e idosos (versão estendida do melhor interesse da criança,

\footnotetext{
${ }^{29}$ Conforme dados obtidos em estudo de DANIEL BORILLO, professor da Universidade de Paris X e pesquisador associado do Centre National de La Recherche Scientifique (CNRS), denominado " $O$ indivíduo homossexual, o casal de mesmo sexo e as famílias homoparentais: análise da realidade jurídica francesa no contexto internacional", in Revista da Faculdade de Direito de Campos, Ano VI, n. 7, dezembro de 2005, p. 104-106.

${ }^{30}$ ANTONIO JUNQUEIRA DE AZEVEDO destaca a importância dessa mudança, dizendo que "si on laisse de côté les aspects formels, il faut dire que le sens substantiel des grands changements dans le droit de famille brésilien, dans les dernières décennies, c'est de rendre plein le príncipe de l'égalité, soit celle de l'homme et de la femme (dans toutes leurs relations, personnelles ou patrimoniales), soit celle des enfants entre eux-mêmes.". L'ordre public dans les relations de famille, in Maria Helena Diniz (coord.), Atualidades jurídicas, São Paulo, Saraiva, 1999, p. 59.

${ }^{31}$ PAULO LUIZ NETTO LÔBO, Famílias, São Paulo, Saraiva, 2008, p. 37.
} 
antes citado), e o da proibição de retrocesso social, além de também se mencionar, no tema, a monogamia, não como "um princípio do direito estatal de família", mas como "regra restrita à proibição de múltiplas relações matrimonializadas, constituidas sob a chancela do Estado ${ }^{, 32}$.

Mas as setas apontando os destinos do Direito de Família estão longe de indicar um só e certo caminho; como adverte Humberto Theodoro Júnior, não há, no Direito, princípio algum, ainda que de ordem constitucional, que possa ser considerado absoluto, ante a relatividade própria à sistemática dos princípios de Direito. Esclarece o mencionado autor que "os princípios, na sua essência não traduzem preceitos mas, sim, valores, os quais, por natureza, são elásticos, sem contornos e limites precisos, e exercem muito mais sua função no terreno da hermenêutica do que no campo das normas, estas, sim, encarregadas de traçar regras claras e precisas sobre o comportamento dos sujeitos de Direito ${ }^{\text {,33. }}$.

A desconstrução dos valores antes consagrados e definidos, iniciada no século XX e que continua no presente, deixa desnorteada a ordem jurídica contemporânea que, desvalida de critérios sólidos para garantia da sua eficácia e coerência, pulveriza-se em microssistemas que não guardam, entre si, a necessária harmonia, e contém, ademais, estrutura por demais genérica, estendendo a limites indesejáveis a atividade complementar do julgador, abalando a confiança do cidadão, por desprezar um dos princípios constitucionais supremos, o da segurança jurídica ${ }^{34}$ que, de nossa parte, teremos o cuidado de, somando-o aos antes mencionados, também considerar.

Isso porque, quando a chamada força normativa constitucional se transmuta de supletiva em principal e - através das entrelinhas de leis esparsas repletas de cláusulas gerais - se faz sentir com pujança, a aterrar o berço do Direito

\footnotetext{
${ }^{32}$ MARIA BERENICE DIAS, Manual de Direito das Famílias, $4^{\text {a }}$ ed. rev., atual. e ampl., São Paulo, RT, 2007, p. 57-69.

${ }^{33}$ A onda reformista do Direito Positivo e suas implicações com o princípio da segurança jurídica, in Revista de Doutrina da $4^{a}$ Região, n. 14, Porto Alegre, EMAGIS, set. 2006, disponível [on line] in http://www.revistadoutrina.trf4.jus.br/artigos/edicao014/Humberto_Junior.htm [16/02/2009].

${ }^{34}$ HUMBERTO THEODORO JÚNIOR, a respeito, alinhava que "aproximando-se de meras declarações de valores (indefinidos e indefiniveis), essa conduta inaceitável, e por isso mesmo, injustificável do legislador, deixa o indivíduo (cuja dignidade diz estar tutelando) entregue à sanha e aos azares de quem detém o poder de julgar as condutas individual e social", in $A$ onda... cit. (nota 33, supra).
} 
comum - o Código Civil -, necessário se torna preservar a legalidade como garantia fundamental, pondo-se a salvo, como alerta Humberto Theodoro Júnior, de abstrações e formulações ambíguas.

Incisivo, o citado jurista afirma que, na atualidade, "Direito não é mais sinônimo de lei, e norma ou preceito não mais se distingue dos princípios. Assim, em nome de pretensos princípios, que muitas vezes não se sabe se existem realmente nem de onde foram extraídos, se cria todo um clima de permissividade para o operador do Direito. Totalmente descompromissado com a lei ditada pelo poder legiferante instituido, o aplicador do Direito procura a regra a aplicar no caso concreto onde bem lhe convier, ou onde bem entender, pois fora do preceito explícito da lei, sempre haverá algum raciocínio, algum argumento, alguma justificação para explicar qualquer tipo de decisão"35.

Aliás, Kant professa que "em suma, ninguém é capaz de determinar, por um princípio qualquer e com plena segurança, o que realmente lhe faria feliz; para isso seria necessária a onisciência"36 e, convenhamos, embora alguns pensem poder se assenhorear de tal saber, nenhum ser humano é dele detentor.

Feita essa breve digressão, é momento de se comentar os antes propalados princípios contidos na Carta Magna.

\subsection{PRINCÍPIO DA DIGNIDADE DA PESSOA HUMANA}

Inicia-se pelo princípio fundamental mais festejado, o da dignidade da pessoa humana, presente no artigo $1^{\circ}$, inciso III, da Constituição Federal e explicitamente repetido em vários outros, no capítulo da família, da criança, do adolescente e do idoso devendo ser mencionados os artigos $226, \S 7^{\circ}$ (que estabelece o princípio da dignidade da pessoa humana como fundamento do planejamento familiar), 227, caput (que reza ter a criança e o adolescente, com absoluta prioridade,

\footnotetext{
${ }^{35}$ A onda... cit. (nota 33, supra).

${ }^{36}$ IMMANUEL KANT. Fundamentação da metafísica dos costumes e outros escritos, trad. Leopoldo Holzbach, São Paulo, Martin Claret, 2003, p. 49.
} 
entre outros, direito à dignidade, a ser assegurado pela família, pela sociedade e pelo Estado) e 230 (que estabelece que a família, a sociedade e o Estado têm o dever, entre outros, de amparar as pessoas idosas, defendendo sua dignidade).

Interessante notar, desde logo, que o Código Civil de 2002 não menciona esse princípio em nenhum momento, a confirmar o acerto das inúmeras críticas sofridas pelo novo e já velho regramento civil, inclusive quanto ao desrespeito, não só à Constituição, mas também aos tratados e convenções internacionais já assinados pelo Brasil.

Considerado um princípio maior, universal, podemos denominá-lo um "princípio continente", ou seja, aquele que traz em si todos os outros, o que é, de certa forma, fator indicativo da sua essência e da dos demais nele contidos.

É Kant, mais uma vez, quem nos dá caminhos para a intelecção desse primeiro princípio, explicando que "no reino dos fins, tudo tem ou um preço ou uma dignidade. Quando uma coisa tem preço, pode ser substituida por algo equivalente; por outro lado, a coisa que se acha acima de todo o preço, e por isso não admite qualquer equivalência, compreende uma dignidade"37.

A idéia do pensador é tão interessante quanto útil, pois põe à mostra o real valor a ser buscado no princípio, na norma, na lei, um "valor interno", obtido por construção jurídica calcada na "moralidade" e na "humanidade enquanto capaz de moralidade", que resulta em uma regra simultaneamente própria e universal, uma regra que, por conter um "valor incondicional", terá o respeito de todos, ganhando vida, "autonomia ... o fundamento da dignidade da natureza humana e de toda a natureza racional" 38 .

Mas, mesmo com essas considerações, permanecem inúmeras dificuldades a serem transpostas, pois os conceitos de moralidade e de humanidade são fluidos, e, assim, como a água ou o ar se amoldam ao recipiente que os contenha, também a moralidade e a humanidade têm a forma das sociedades que as contêm.

\footnotetext{
${ }^{37}$ Fundamentação... cit. (nota 36 supra), p. 65.

${ }^{38}$ Fundamentação... cit. (nota 36 supra), p. 66.
} 
Como se identificar quais são as ações dotadas de valor superior, merecedor do respeito coletivo, dentro da realidade da específica sociedade na qual se realizam, é tarefa que demanda longa observação e amadurecimento dessas ações, a fim de que seja possível eleger, entre elas, quais devem, ou não, ser erigidas à categoria de dever.

Reconhecer dignidade em toda e qualquer circunstância, no campo do Direito, equivale a indignificar o próprio princípio distinguidor, tornando-o uma inutilidade, mera retórica, como pouco antes apontado. É o efeito, na designação de Ricardo Luis Lorenzetti, da "inflação" de direitos fundamentais ${ }^{39}$.

Sérgio Resende de Barros ministra lição no sentido de que muito se tem discorrido sobre direitos humanos, de forma ideológica e demagógica, sem se definir, em verdade, no que se constituem tais direitos; mas que são "poderes-deveres de todos para com cada um e de cada um para com todos, visando realizar a essência humana em todas as existências humanas, concretizar o ser humano em todos os indivíduos humanos, segundo os padrões de dignidade do momento histórico"40.

Talvez (e nem mesmo o fim deste trabalho poderá me fazer retirar essa condicional) uma pista de que nos aproximamos de uma aceitável definição aplicável ao Direito para dignidade da pessoa humana esteja na denominação que acima utilizamos - "princípio continente" - um princípio que, contendo todos os demais, é deles interdependente, deles necessita para ser suficientemente identificado, datado, compreendido e valorado, dentro do chamado "juízo de ponderação de interesses opostos".

Professa Lorenzetti que “... não há princípios absolutos. Há princípios que dão a impressão de sê-lo, como o da dignidade da pessoa, e contudo estão submetidos ao juízo de ponderação" 41 .

\footnotetext{
${ }^{39} \mathrm{O}$ citado autor, a propósito, afirma ser “.... simples redigir uma lei, uma Constituição ou um tratado, conferindo direitos, estes, porém, ao serem demasiadamente abundantes, se desvalorizam. O efeito deste fenômeno é ... a ineficácia.", in Fundamentos do Direito Privado, São Paulo, RT, 1998, p. 162.

${ }^{40}$ Direitos humanos da família: dos fundamentais aos operacionais. In: GROENINGA, Giselle Câmara; PEREIRA, Rodrigo da Cunha (coords.). Direito de familia e psicanálise. São Paulo: Imago, 2003, p. 143-154.

${ }^{41}$ Fundamentos... cit. (nota 39 supra), p. 427.
} 
E assim é porque não se vislumbra, no âmbito do Direito, razão útil para se discutir sobre dignidade da pessoa humana fora do contexto social em que aplicado o propalado princípio, da mesma forma que não haveria porque se debater sobre o significado de um quadro, se dele fossem retiradas todas as cores e formas, restando apenas a tela branca que a elas dava suporte.

Porém, presente desde 1948 em diversas declarações de direitos da Organização das Nações Unidas e colocado como princípio fundante na Carta Constitucional brasileira de 1988, é dever do operador do Direito jurisdicizar o conceito nascido filosófico, para que ele tenha aplicação prática efetiva, com a cautela de evitar-se o individualismo exacerbado, infirmador dos interesses da coletividade, pois, "o próprio Direito posto não é somente norma. O Direito é sistema, e sistema de $2^{a}$ ordem, porque é instrumento da sociedade criado com a função de prevenir e dirimir conflitos ... em que "sistema" é entendido como um conjunto de elementos que evoluem e interagem de modo relativamente uniformecomo o sistema solar, na Astronomia, ou as células, na Biologia",42.

\subsection{PRINCÍPIO DA SOLIDARIEDADE}

Vem o segundo princípio fundamental, da solidariedade, esculpido no inciso I, do artigo $3^{\circ}$, da Constituição Federal e, assim como o da dignidade da pessoa humana, nela inaugura presença como princípio jurídico, estando esses dois intimamente ligados.

Espraia-se por diversos outros artigos, interessando-nos, em especial, os artigos 226 (solidariedade familiar), 227 (solidariedade à criança, ao adolescente e aos portadores de deficiência) e 230 (solidariedade às pessoas idosas), todos do capítulo VII, tocante à família, à criança, ao adolescente e ao idoso.

\footnotetext{
${ }^{42}$ ANTONIO JUNQUEIRA DE AZEVEDO, O Direito ontem e hoje. Crítica ao neopositivismo constitucional e à insuficiência dos direitos humanos, Revista do Advogado, ano XXVIII, $n^{\circ}$ 99, São Paulo, AASP, setembro de 2008, p. 12-13.
} 
É uma relação de responsabilidade que vincula o indivíduo à vida, aos interesses e às responsabilidades de um grupo social, de uma nação, ou da própria humanidade.

Como dever imposto à família, realiza-se através da comunhão de vida de cônjuges e companheiros, bem como do cuidado desses com a prole - até que essa alcance a emancipação plena - e de todos esses entre si, durante toda a sua existência, extensivo tal dever a outros entes (como avós, netos, tios, sobrinhos, padrastos, madrastas etc.).

Sem prejuízo, é também dever da sociedade e do Estado socorrer tanto a entidade familiar como cada um de seus membros, com a finalidade de preservar o núcleo primário que a Constituição estabelece como base da sociedade e, nesse prisma, podemos classificar a solidariedade como um "sentimento interessado".

Essa, aliás, a visão de família posta no preâmbulo da Convenção Internacional sobre os Direitos da Criança, de 1989, que, como grupo fundamental da sociedade e ambiente natural para o crescimento e bem-estar de todos os seus membros, e em particular das crianças, deve receber a proteção e assistência necessárias a fim de poder assumir plenamente suas responsabilidades dentro da comunidade.

\subsection{PRINCÍPIO DA IGUALDADE}

Passando ao campo dos princípios gerais, surge o da igualdade, no artigo $5^{\circ}$, caput, da Carta Constitucional, logo minudenciado no inciso I do referido artigo (igualdade entre homens e mulheres) e, no capítulo VII, nos artigos 226, § $5^{\circ}$ (que estabelece igualdade no exercício de direitos e deveres referentes à sociedade conjugal, pelo homem e pela mulher) e $227, \S 6^{\circ}$ (que estipula igualdade entre os filhos havidos ou não da relação de casamento, ou por adoção).

Isonomia, enquanto estado daqueles que são governados pelas mesmas leis, é algo desejável e mesmo necessário. Contudo, há situações em que não é 
suficiente, ou mesmo adequada, a aplicação fria do princípio isonômico, como lembrado por Rui Barbosa, na sua "Oração aos moços": "A regra da igualdade não consiste senão em quinhoar desigualmente aos desiguais, na medida em que se desigualam. Nesta desigualdade social, proporcionada à desigualdade natural, é que se acha a verdadeira lei da igualdade. O mais são desvarios da inveja, do orgulho, ou da loucura. Tratar com desigualdade a iguais, ou a desiguais com igualdade, seria desigualdade flagrante, e não igualdade real. Os apetites humanos conceberam inverter a norma universal da criação, pretendendo, não dar a cada um, na razão do que vale, mas atribuir o mesmo a todos, como se todos se equivalessem." ${ }^{43}$.

Relativizar a igualdade, porém, é tarefa das mais espinhosas e perigosas, porque quando se percebe a ausência de paradigmas aplicáveis a uma determinada questão, tende-se a trazer, como solução, respostas dadas pela lei a hipóteses por vezes pouco ou nada similares, lendo-se onde nada há escrito e escrevendo-se onde nada mais cabe ser dito.

Em nome da analogia, criam-se dragões doutrinários e jurisprudenciais que passam a sobrevoar o castelo do Direito, querendo lançar suas chamas destruidoras para aniquilar os pilares seculares do conhecimento jurídico, monstruosidades que só podem ser detidas pela lança segura da ordem constitucional democrática.

Longe das iniqüidades, deve sobreviver o verdadeiro espírito da igualdade, só inteligível mediante leitura conjunta com os demais aqui tratados, ainda que alguns não apreciem o exercício dos direitos-deveres decorrentes da vida em sociedade $^{44}$.

\footnotetext{
${ }^{43}$ Oração aos moços; edição popular anotada por Adriano da Gama Kury, 5a. ed. - Rio de Janeiro, Fundação Casa de Rui Barbosa, 1997, p. 26.

${ }^{44} O$ Direito... cit. (nota 42 supra), p. 13.
} 


\subsection{PRINCÍPIO DA LIBERDADE}

Também no artigo $5^{\circ}$, caput, encontra-se o princípio da liberdade, assim como, mais especificamente, nos artigos 226, § $7^{\circ}$ (liberdade de planejamento familiar) e 227, caput (que reza ter a criança e o adolescente, com absoluta prioridade, entre outros, direito à liberdade, a ser assegurado pela família, pela sociedade e pelo Estado).

Tal princípio, historicamente trazido na célebre trilogia revolucionária francesa cunhada por Rousseau (Liberté, Egalité, Fraternité) e consagrado a partir da Declaração de Direitos do Homem, vem tendo seu conceito reengendrado desde o Iluminismo, para alcançar agora uma amplitude até pouco tempo inimaginável, colocando o Direito, como aponta Junqueira, no papel de "coordenar, organizar e limitar as liberdades, justamente para garantir a liberdade individual"45.

Ensina o citado jurista que "com a idéia de sistema de $2^{a}$ ordem, o Direito incorpora-se a toda a vida social, o sistema maior, e passa a se justificar não somente pela lei do maior número, mas, via interpretação, por todo um ... 'processo de argumentação sensivel ao que é socialmente útil' - dando mais legitimidade à própria Constituição e às leis em geral".

Dessa forma, a liberdade de formação, manutenção e extinção do núcleo familiar sem quaisquer interferências estranhas aos seus membros passa a ser considerada direito quase absoluto; sofre, todavia, como os princípios antes elencados, a força moderadora integrativa do próprio sistema que lhe dá sustentação.

Em abono, a prudente lição de Lorenzetti, de que “... os conflitos entre os princípios e valores intra-sistemáticos são tratados mediante uma análise da capacidade argumentativa de cada um, que se denomina juízo de ponderação"46.

E, embora hoje possa ser formada família sem a necessidade do vínculo matrimonial, reconhecidas mesmo outras entidades familiares fora do casamento, a

\footnotetext{
${ }^{45}$ Manual... cit. (nota 32 supra), p. 61.

${ }^{46}$ Fundamentos... cit. (nota 39 supra), p. 428.
} 
verdade é que ainda há restrições importantes (como nos casos encontrados no Código Civil, artigos 1574 e seu $\S$ único, e 1580, $\S 2^{\circ}$, que estipulam prazo para separação consensual e divórcio, bem como estabelecem possível sua recusa judicial; e 1641, inciso II, que impõe regime de separação de bens ao nubente maior de 60 anos), conquanto apontadas como inconstitucionais por vários doutrinadores ${ }^{47}$.

Dentro deste princípio, deve ser lembrado polêmico direito fundamental de quarta geração dele derivado, o "direito de ser diferente", surgido do processo de diferenciação de um indivíduo em relação ao outro, como nos debates atinentes à homossexualidade e à mudança de sexo ${ }^{48}$.

\subsection{PRINCÍPIO DA AFETIVIDADE}

A afetividade é, na atualidade, o princípio jurídico mais estudado, mencionado e utilizado nas construções das relações de família, embora estando apenas implícito na ordem constitucional, como nos artigos $226, \S 4^{\circ}$ (reconhecimento da família monoparental como entidade familiar) e 227, caput (garantia à criança e ao adolescente da convivência familiar), e seu $\S 6^{\circ}$ (equiparação dos filhos havidos ou não da relação de casamento, ou por adoção).

Não se deve confundi-lo com o afeto, fato psicológico ${ }^{49}$, ou o direito ao afeto, "o primeiro dos direitos humanos operacionais da família" "50; trata-se a afetividade de uma verdadeira presunção que gera deveres decorrentes dos vínculos familiares formados através "das relações socioafetivas e da comunhão de vida, com primazia sobre as considerações de caráter patrimonial ou biológico" ${ }^{\text {, }}$, como se encontra, por exemplo, nos artigos 229 (dever mútuo de assistência entre pais e filhos) e 230 (dever familiar de amparo aos idosos) da Constituição Federal, deveres

\footnotetext{
${ }^{47}$ Entre eles PAULO LUIZ NETTO LÔBO, in Famílias cit. (nota 31 supra), p. 47, e MARIA BERENICE DIAS, in Manual... cit. (nota 32 supra), p. 61.

${ }^{48}$ RICARDO LUIS LORENZETTI, desde 1998, assim o classifica, cf. Fundamentos... cit. (nota 39 supra), p. 154.

${ }^{49}$ Conforme adverte PAULO LUIZ NETTO LÔBO, in Famílias cit. (nota 31 supra), p. 48.

${ }^{50}$ Direitos Humanos... cit. (nota 11 supra).

${ }^{51}$ Famílias cit. (nota 31 supra), p. 47.
} 
esses impostos sem consideração sobre existência de amor ou afeição entre tais pessoas.

Ele integra e complementa os conceitos, antes expostos, dos dois princípios fundantes, da dignidade e da solidariedade.

Podemos mesmo nos utilizar do termo "afetividade" para adjetivar os dois princípios fundamentais acima citados, de forma a trazê-los ao campo específico do Direito de família, que se traduziriam em "dignidade afetiva da pessoa humana" e em "solidariedade afetiva", representativos da prevalência do valor da pessoa humana sobre os valores materiais, patrimoniais, nas relações de família.

\subsection{PRINCÍPIO DA CONVIVÊNCIA FAMILIAR}

Prevista no art. 227, caput, da Carta Magna, a convivência familiar mostra-se no efetivo e constante contato entre pessoas unidas por laços de comunhão de vida, revelados por identidade de relações socioafetivas, de parentesco - seja ele natural ou não - e de moradia.

O suporte material do lar, da casa, "asilo inviolável do indivíduo", conforme estabelece o artigo $5^{\circ}$, inciso XI, da Constituição Federal, embora não essencial, permite o exercício da vida em família na sua plenitude, individualizando e protegendo a entidade familiar, de modo a propiciar constante e perene convívio, em clima solidário e de afeto.

O direito à convivência familiar é norteador não só da família nuclear e matrimonial, mas daquela resultante do desenlace conjugal, onde não só os pais, mas os irmãos, avós e tios, entre outros, possam ter assegurada a continuidade da intimidade de que desfrutavam entre si, devendo o Estado, nesse particular, produzir ações afirmativas efetivas e céleres, de modo a garantir, em especial, "o melhor interesse da criança e do adolescente" - abaixo tratado - dentro do sempre lembrado entrelaçamento de princípios. 
Sem a pretensão de delimitar ou esgotar o rol de princípios constitucionais norteadores do Direito de família, nomeamos, afinal, o do melhor interesse da criança, ligado à teoria da proteção integral, com assento nos artigos 227, caput e seu $\S 6^{\circ}$, da Constituição Federal.

A necessidade de proporcionar à criança uma proteção especial foi enunciada na Declaração de Genebra de 1924 sobre os Direitos da Criança e na Declaração dos Direitos da Criança adotada pela Assembléia Geral em 20 de novembro de 1959, e reconhecida na Declaração Universal dos Direitos Humanos, no Pacto Internacional de Direitos Civis e Políticos (em particular nos Artigos 23 e 24), no Pacto Internacional de Direitos Econômicos, Sociais e Culturais (em particular no Artigo 10) e nos estatutos e instrumentos pertinentes das Agências Especializadas e das organizações internacionais que se interessam pelo bem-estar da criança, além de estar, a partir de 1990, prevista no ECA, como, em capítulo a seguir, se minudenciará.

Anote-se, em começo, não nos parecer correta a postura de se querer incluir os idosos e mesmo as pessoas portadoras de deficiência - ou, como denominam alguns, portadoras de necessidades especiais - em igual nível de tratamento ao da criança e do adolescente, pois, conquanto existam garantias constitucionais expressamente asseguradas a tais pessoas, não se pode olvidar que os interesses da criança e do adolescente têm, na inafastável expressão constitucional, "absoluta prioridade".

Como mais à frente se verá, no Capítulo III da presente tese, a criança e o adolescente passam a ser sujeitos de direito, reescrita a história do pátrio poder, até mudado seu nome - para poder familiar - tudo para se deixar sublinhado o novo papel dos pais e dos filhos, esses últimos devendo ter prioritário tratamento pelo Direito. 


\subsection{PRINCÍPIO DA SEGURANÇA JURIDICA}

O princípio da segurança vem ombreado, no preâmbulo da Constituição Federal, a vários daqueles nos tópicos antecedentes nomeados, além de expresso no art. 5 $5^{\circ}$, caput, da Carta Constitucional, merecendo, assim, igual destaque e consideração.

O Estado Democrático de Direito tem sua intelecção fundeada nos princípios constitucionais, e sendo um deles o da segurança, presta-se esse a controlar o desenfreado desejo de reformas sem uma prévia e detida reflexão sobre suas conseqüências no ordenamento jurídico.

As renovações de ocasião ou de moda, que podem resultar inócuas por deixarem inalterada a substância das normas ou, pior, resultar desestabilizadoras do sistema jurídico, devem ser ativamente repudiadas e combatidas.

A confiança das pessoas na segurança jurídica, a certeza de que a lei é o que se lê nela e não o que se diz dela, constitui elemento fundamental do Estado de Direito, pois representa sua evolução de um sistema formal para "um sistema que contém exigências materiais" ${ }^{, 52}$.

Canotilho, de forma irretocável, conceitua o princípio em comento, como o direito que os indivíduos têm "de poder contar com o fato de que aos seus atos ou às decisões públicas concernentes a seus direitos, posições ou relações jurídicas fundadas sobre normas jurídicas válidas e em vigor, se vinculem os efeitos previstos e assinados por estas mesmas normas"

Dessa maneira respeitado o princípio da segurança jurídica, por ele serão evitados abusos na edição de leis "abertas", repletas de cláusulas gerais bem ao gosto dos que se arvoram no papel de "boca da lei", trazendo instabilidade ao ordenamento jurídico; será evitado que "o juiz se torne legislador; e o que é pior, legislador ex

\footnotetext{
${ }^{52}$ BERTRAND MATHIEU, Relatório na XV $\mathrm{X}^{\mathrm{a}}$ Mesa Redonda Internacional de Aix-en-Provence, sobre o tema "Constitution et sécurité-juridique", set/1999, in Annuaire Internacional de Justice Constitutionnelle, XV, 1999, Paris, Economica, 2000, p. 155-156.

${ }^{53}$ Direito Constitucional e Teoria da Constituição, $3^{\text {a }}$ Ed. Coimbra, Almedina, 1999, p. 250.
} 
post facto, pois a lei só será dita em seu conteúdo completo e definitivo depois de consumado o fato sobre que irá incidir," ${ }^{54}$.

Como os demais, contudo, não representa valor absoluto, cabendo ao legislador, então, operar a conciliação entre os diferentes imperativos, norteando-se pelas regras já lembradas nesse trabalho e que, ainda algumas vezes, serão necessariamente repetidas, porque inerente seu constante exercício às soluções apresentadas ao cerne do problema.

\section{Avanços e Retrocessos do Direito de Família na Legislação e na JURISPRUDÊNCIA}

O Direito de Família que primeiro aportou dos além-mares no nosso continente foi o trazido pelos portugueses, com suporte no Direito canônico, patriarcal, e viveu durante o período colonial e imperial.

Com as Ordenações do Reino, que faziam remissão, em matéria de família, ao citado direito religioso, marcaram-se tempos de domínio da Igreja sobre a vida privada das pessoas, incumbido o sacerdote, em caráter oficial, dos registros de nascimento, casamento e morte. A Consolidação das Leis Civis, elaborada pelo advogado Teixeira de Freitas entre 1855 (ano de sua contratação pelo governo) e 1858 (ano da entrega do trabalho) é a primeira empreita tendente à organização da legislação até então existente sobre as relações de família (entre várias outras matérias ali tratadas), dirigida a primeira seção aos direitos pessoais nas relações de família, dividida essa em partes, a saber, o casamento, o pátrio poder, e o parentesco, complementada pela instituições supletivas da tutela e da curatela.

A passagem do Império à República pouco modificou a situação, pois, conquanto proclamada a laicidade do Estado e, conseguintemente, do Direito de Família, vigoraram, então, expressões que hoje são apenas história, como casamento indissolúvel, filhos legítimos e ilegítimos, chefe da família (em relação ao homem) e

${ }^{54}$ A onda... cit. (nota 33 , supra). 
auxiliar (quanto à mulher), mas que duraram por muitos anos, até que fossem quebradas as barreiras do patriarcalismo por novos ideais e idéias, com o Estatuto da Mulher Casada, de 1962, a Lei do Divórcio, de 1977 e a Constituição Federal de 1988, marco supremo da revolução das instituições de família.

Assim, no correr do tempo, foi a família ocupando diferentes funções (de cunho religioso, político, econômico e procriativo), e continua ela tendo destacado espaço na sociedade, assumindo nova função, de solidariedade, ninho que acolhe e preserva o indivíduo hígido para enfrentar as vicissitudes da vida atual.

Deixadas longe foram as preocupações de ordem patrimonial que a inspiravam, para se deitar olhos nos aspectos pessoais da relação de família.

O Código Civil de 1916 e seu autoritarismo na questão da família foram soterrados pela igualdade trazida pela Constituição de 1988, uma radical mudança de paradigmas, passando a imperar a dignidade da pessoa humana, a solidariedade e a igualdade na formação dos conceitos basilares do assunto.

Tudo isso vem se realizando não sem encontrar forte resistência gerada por uma herança patriarcal intensa e um posicionamento religioso hermético que só agora vem sendo abrandado na tentativa de se diminuir a fuga de fiéis excluídos mercê de separação, divórcio, controle familiar, apenas para citar os motivos mais comuns, entre tantos outros - do pleno exercício de sua fé.

Dentro desse quadro, pode-se lembrar que, até passado não tão longínquo, o país não contava com a dissolução do vínculo do casamento (que, aliás, foi alcançada de forma progressiva, sempre por conta da luta contra as correntes contrárias), obrigando a inúmeras uniões serem formadas fora da proteção legal, e abraçava norma que impedia ao cônjuge casado registrar filho havido fora do casamento no seu nome.

Sanções cíveis e criminais foram estabelecidas para quem tivesse a coragem de assumir a realidade de nova família, bem como gerar filhos sem a benção da lei, tudo em defesa da família patrimonializada, com resquícios até hoje. 
Maria Berenice Dias, na questão, escreve que "a tentativa de perpetuar a família fez o casamento indissolúvel e, mesmo depois do divórcio, ainda o Estado resiste em dissolvê-lo. Impõe prazos e tenta punir culpados. O interesse na preservação da família matrimonializada é tão grande que até 2005 o adultério era crime. A bigamia ainda é. O Estado se imiscui de tal maneira na intimidade do casal que impõe o dever de fidelidade (Cód. Civil, art. 1.566, I). Considera o adultério como justa causa para a separação (Cód. Civil, art. 1.573, I), e o reconhecimento da culpa do infiel faz com que ele perca o nome de casado (Cód. Civil, art. 1.578). Alimentos, só recebe o quanto baste para sobreviver (Cód. Civil, art. 1.704, parágrafo único)." $" 55$.

Sob inspiração liberal individualista - que se faz presente na maioria dos códigos do Ocidente -, nosso código civil ainda realça sobremaneira o aspecto patrimonial, muitas vezes sobrepondo-o ao pessoal, como se verifica do exame de vários artigos, como os atinentes às causas suspensivas do casamento, às autorizações de casamento, aos impedimentos matrimoniais, à dissolução da sociedade conjugal e do casamento e sua partilha de bens, à filiação, ao regime de bens, à tutela e curatela, entre outros.

Não se pretende negar, por lógico e evidente, ao Direito de Família a função de tutela, também, dos direitos de caráter assistencial e patrimonial a ele atinentes. O que se espera, contudo, é que a questão patrimonial não mais seja preponderante, pois o sentimento geral aponta no sentido de que o Direito de Família deva ser, dos direitos civis, o de caráter mais pessoal, favorecendo a função da família como centro de formação pessoal e afetiva do indivíduo.

Dentro dessa perspectiva, vem a jurisprudência se inclinando no sentido de considerar com maior peso argumentos antes relegados a segundo plano, como a preponderância do aspecto afetivo sobre o biológico; a efetiva concreção do superior interesse da criança em questões como adoção, guarda e alimentos; a importância da afetividade nas relações entre indivíduos e os laços dessa decorrentes; a questão do direito à individualidade, à intimidade, ao afeto e a felicidade dentro da convivência familiar, tudo com objetivo de ofertar resposta às perplexidades ainda existentes na

\footnotetext{
${ }^{55}$ Bem feito! Quem manda ser mulher?, disponível [on line] in http://www.mundolegal.com.br/? FuseAction=Artigo_Detalhar\&did=26674 [06/01/2009].
} 
matéria, pois que se insiste em enxergar interesses econômicos subjacentes a maioria dos pleitos, com tendência, então, de dar-se solução padrão às questões, resolvendose apenas o lado material do problema, tratando-se como secundários, ou até inexistentes, aqueles que afetam, de forma direta e importante, a dignidade das pessoas envolvidas.

Posicionamentos jurisprudenciais recentes, entretanto, dão mostra de que um consenso está longe de ser alcançado, pois enquanto uma Câmara do Tribunal de Justiça do Estado de São Paulo decide, de forma unânime, incabível o reconhecimento de direitos previdenciários a par homossexual, posto "inconstitucional qualquer projeto que vise equiparar a entidade familiar à união de lésbicas e pederastas" ${ }^{" 56}$, outra julga, também de forma unânime, que tais direitos devem ser reconhecidos, porquanto "inaceitável a alegação de que o artigo 226 da Constituição Federal diz respeito somente à união entre homem e mulher. Essa interpretação é isolada, restritiva. Há que ser observado, como já ilustrado, os princípios constitucionais da igualdade e da dignidade da pessoa humana"57.

Outra não é a situação em caso de dirimir-se sobre a possibilidade de existência de união estável homoafetiva - com conseqüente julgamento da mesma perante Vara de Família -, encontrando-se julgados aduzindo que "como a união entre duas pessoas do mesmo sexo não é considerada em nosso ordenamento jurídico como casamento e nem como união estável e, portanto, não possui nenhuma ligação como o Direito de Família, afasta-se a competência da Vara Especializada, devendo o processo ser apreciado por uma das varas cíveis da comarca" ${ }^{\text {"58 }}$, inclusive mencionando precedente do $\operatorname{STJ}^{59}$ e, de outro modo, há acórdão afirmando a

\footnotetext{
${ }^{56}$ APELAÇÃO CÍVEL COM REVISÃO n 425.148-5/2-00, da Comarca de São Paulo, em que é Apelante ASSOCIAÇÃO DE INCENTIVO A EDUCAÇÃO E SAÚDE DE SÃO PAULO, sendo Apelados IPESP - INST. PREV. DO ESTADO DE SÃO PAULO e IPREM - INST. PREV. DO MUNICÍPIO DE SAO PAULO, rel. ALBERTO ZVIRBLIS, 05/10/2006.

${ }^{57}$ APELAÇÃO CÍVEL COM REVISÃO n ${ }^{822.918-5 / 1-00, ~ d a ~ C o m a r c a ~ d e ~ S a ̃ o ~ V i c e n t e, ~ e m ~ q u e ~ e ́ ~}$ apelante PAULO ROBERTO RODRIGUES sendo apelado INSTITUTO DE PREVIDÊNCIA DOS SERVIDORES MUNICIPAIS DE SÃO VICENTE, rel. MARREY UINT, 02/12/2008.

${ }^{58}$ CONFLITO DE COMPETÊNCIA $n^{\circ} 158.232-0 / 7-00$, da Comarca de SÃO PAULO, em que é suscitante MM. JUIZ DE DIREITO DA $3^{\text {a }}$ VARA DA FAMÍLIA E SUCESSÕES DE PIRACICABA sendo suscitado MM. JUIZ DE DIREITO DA $3^{\text {a }}$ VARA CÍVEL DE PIRACICABA, rel. Moreira de Carvalho, v. u., 03/11/2008.

${ }^{59}$ Do seguinte teor: "A união entre homossexuais juridicamente não existe nem pelo casamento, nem pela união estável, mas pode configurar sociedade de fato, cuja dissolução assume contornos econômicos, resultantes da divisão do patrimônio comum, com incidência do Direito das
} 
competência da vara especializada, uma vez que "além da peculiaridade de se tratar de casal homossexual, diante da aparente ausência de regulamentação da espécie, devem os lidadores do Direito estabelecer parâmetro com aquele constituído por parceiros heterossexuais, tendo-se como base os princípios constitucionais da

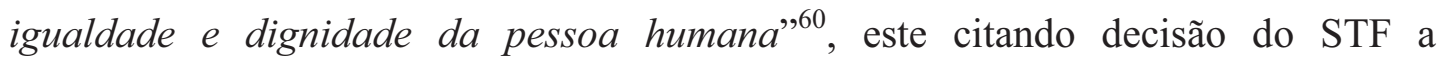
respeito $^{61}$.

Divergências ocorrem, igualmente, na questão da filiação, como, por exemplo, no choque entre a verdade biológica e a socioafetiva, havendo, em favor dessa última, vários julgados decidindo que nesses casos, o que prevalece não é a verdade biológica, mas a socioafetiva, porquanto a pessoa que teve reconhecida a paternidade passa a gozar do estado de filho, que não the pode ser retirado simplesmente por ato unilateral do pai registral, como se o ato fosse de mero capricho, o reconhecimento é irrevogável e irretratável, pois caracterizada uma adoção. Em verdade, apenas nas hipóteses de o filho desejar estabelecer a verdade biológica é que a jurisprudência tem admitido a revogação do reconhecimento levado a efeito ${ }^{62}$.

Em sentido contrário, em defesa daquela primeira, outros salientam que "embora esse ora apelante admitisse haver voluntariamente reconhecido a paternidade do apelado, com cuja genitora ele (recorrente) se casara (folhas 26) após esse nascimento (folhas 7), e em que pese então consciente de que não fosse o pai, é caso desse provimento do recurso porque devem sobrelevar os princípios da veracidade e da legitimidade do registro público"63.

Obrigações" (REsp 502.995/RN, rel. Ministro Fernando Gonçalves, quarta turma, julgado em 26.04.2005, DJ 16.05.2005 p. 353).

${ }^{60}$ APELAÇÃO CÍVEL SEM REVISÃO no 552.574-4/4-00, da Comarca de São Paulo, em que é apelante F. A. D. V. sendo apelada A. D. G., rel. CAETANO LAGASTRA, 12/03/2008.

${ }^{61} \mathrm{O}$ aresto menciona que "até mesmo o Supremo Tribunal Federal acenou para que a questão se dirija ao Direito de Família; ao julgar a Medida Cautelar na Ação Direta de Inconstitucionalidade 3300 - Distrito Federal, em 03/02/2006, onde o Ministro CELSO DE MELLO afirmou que a união homossexual deve ser reconhecida como uma entidade familiar e não apenas como 'sociedade de fato'."' (nota 60 supra).

${ }^{62}$ APELAÇÃO CÍVEL COM REVISÃO n 534.955-4/1-00, da Comarca de Jundiaí, em que é apelante G. F. S. sendo apelado L. C. F. S., menor representado por sua mãe, rel. JOAQUIM GARCIA, 08/10/2008.

${ }^{63}$ APELAÇÃO CÍVEL COM REVISÃO no 532.832-4/6-00, da Comarca de BARUERI, em que é apelante M.D.V. sendo apelados R.M.V. (menor representado por sua mãe), rel. ENCINAS MANFRE, 11/12/2008. 
Diverso não se mostra o quadro no âmbito legislativo, onde os debates no assunto são incessantes.

O Deputado Clodovil Hernandes, baseado em anterior proposta da Deputada Laura Carneiro, apresentou projeto de lei onde seguindo uma tendência mundial de tolerância em relação às diferenças, procura-se atender reivindicação dos grupos homossexuais com vistas a integrá-los no ordenamento jurídico e caminhar para a eliminação de preconceitos em razão da orientação sexual.

Tal projeto obteve, do relator Deputado Maurício Trindade, voto desfavorável onde se ressalta que embora as relações patrimoniais entre pessoas do mesmo sexo sejam cada vez mais comuns e as relações homossexuais sejam aceitas há algum tempo, os companheiros ou companheiras não podem constituir família, no tradicional e exato termo em que ser assenta nossa sociedade.

Pondera que um contrato para fins patrimoniais, de união civil ou de sociedade de fato, por não estar vedado pela Constituição Federal ou pela lei infraconstitucional, pode ser perfeitamente pactuado entre quem quer que seja sem que haja necessidade de alteração da legislação em vigor ${ }^{64}$.

Também o Deputado Cândido Vaccarezza traz projeto de lei fazendo um diagnóstico da legislação em vigor e reproduzindo neste projeto os conceitos que se harmonizam com as reivindicações sociais atuais sobre este tema. Esclarece que a resistência no reconhecimento de unidades familiares constituídas por relações homoafetivas é justificada, por muitos, com o argumento jurídico de que a legislação utilizou os termos "homem" e "mulher" para definir os sujeitos da relação. Dá nova redação ao conceito de união estável, mantendo a exigência da publicidade, estabilidade e objetivo de constituição familiar, mas definindo os sujeitos da relação como "pessoas capazes", englobando as relações entre homossexuais e heterossexuais.

E, tendo sido mais incisivo em questões de alto dissenso, recebeu extenso voto divergente do relator, Deputado José Linhares, este enfatizando que, embora a Constituição Federal tenha determinado que a lei facilitaria a conversão da união

\footnotetext{
${ }^{64}$ O Projeto de Lei 580/07 e respectivo voto constam, na íntegra, do Anexo B, sob n. 2, desta.
} 
estável em casamento, jamais foi intenção do Constituinte equipará-la ao instituto do casamento. Sublinha que o projeto propõe o reconhecimento da união estável entre duas pessoas capazes, não fazendo qualquer distinção entre o homem e a mulher, podendo então a união estável ser reconhecida entre homem que vive com homem ou entre mulher que convive com outra mulher e que tal proposição contraria o texto constitucional, porque a Constituição só reconhece a união estável entre o homem e a mulher como entidade familiar, segundo está expresso no $\S 3^{\circ}$ do art. 226 da Lei Maior, destacando que a Carta Magna não reconhece como entidade familiar a união estável existente entre mulher com mulher ou entre homem com homem. Aponta ser relevante, ainda, que a Constituição Federal só poderá ser modificada através de emenda constitucional ou por outra Constituição, e nunca por lei complementar e só este fato já é o bastante para reconhecer a ilegalidade do projeto de lei em comento.

Mereceu, também, voto em separado do Deputado Pepe Vargas (a favor do projeto de lei em referência), que procurou responder aos óbices do relator, aduzindo que "é verdade que a Constituição Federal só poderá ser modificada através de emenda constitucional ou por outra Constituição, mas no caso em tela, conforme já mencionado, não se trata de modificação, mas sim de regulamentação da matéria. Quando o nobre relator afirma que a proposição contraria o texto constitucional, porque a constituição só reconhece a união estável entre o homem e a mulher como entidade familiar, comete um deslize quanto à interpretação da letra da lei”.

Aduz que a Constituição Federal na realidade não exclui, expressamente, a proteção das relações homoafetivas, apenas omitindo a regulamentação, o que evidencia o pensamento Kelseniano no sentido de que "tudo o que não está expressamente proibido, está, implicitamente permitido", abrindo uma lacuna para interpretação analógica do artigo, devendo seguir a hermenêutica de um sistema de normas e princípios constitucionais fundamentais.

Argumenta que no reconhecimento da união estável como entidade familiar não se deve excluir tais princípios; nesse sentido, a Constituição Federal consagra como fundamento do Estado Democrático do Direito a dignidade da pessoa humana; como objetivo, a construção de uma sociedade livre, justa e solidária, sem 
preconceitos de sexo e de quaisquer formas de discriminação; e como princípios fundamentais os direitos de liberdade e igualdade.

Conclui que, portanto, as pessoas sejam elas do mesmo sexo, são livres para atender a sua opção sexual, bem como a constituição de entidade familiar através de união homoafetivas, desde que se vislumbre na vida em comum os pressupostos de notoriedade, publicidade, fidelidade, e sinais explícitos de uma verdadeira comunhão de vida.

O Deputado Manoel Ferreira, igualmente, ofertou voto em separado (contra o mesmo projeto de lei), argumentando que "esta tal Proposta, sobre ser imoral, do nosso ponto de vista, ferindo-se os mais comezinhos princípios éticos de nossa sociedade, e também os bons costumes tão veementemente defendidos pelo novel Código Civil, está eivada de inconstitucionalidade, afronta de modo vergonhoso a Lex Fundamentalis do País. A união estável, permitida pelo art. 226, $\S 3^{\circ}$ de nossa Magna Carta, em nenhum momento pode ser tida como a união entre pessoas do mesmo sexo" ${ }^{\text {65 }}$.

Vê-se, dessa forma, que o debate sobre o futuro do Direito de Família está longe de se encerrar, parecendo, ao contrário, infindável, pois, a cada instante, novas questões e hipóteses são levantadas, antes mesmo de se descobrir um caminho confiável para se alcançar os desígnios de justiça desejados pela sociedade, constantemente abrindo-se trilhas alternativas e atalhos, nem sempre seguros e de destino incerto, onde mergulham em sonhos os que se sentem desassistidos pelo Direito.

Nossa tarefa, na presente tese, é a de mapear as estradas existentes e apontar qual delas está apta a cumprir a missão de conduzir a sociedade ao seu almejado destino, dentro das melhores condições de equilíbrio entre o veículo a ser utilizado (no caso, a Constituição e as leis infraconstitucionais), a distância a ser percorrida (pela percepção de quais situações sociais estão mais, ou menos, próximas de transformarem-se em imperativos autorizantes) e velocidade a ser empregada (aqui entendida como o tempo necessário para que as mudanças se façam de forma natural e segura, dentro do respeito à lei), sinalizando o trajeto com os princípios

\footnotetext{
${ }^{65}$ O Projeto de Lei 674/07 e respectivos votos constam, na íntegra, do Anexo B, sob n. 3, desta.
} 
constitucionais que, a cada etapa da jornada, estarão a ditar o ritmo e a maneira para ser vencido cada trecho sem qualquer acidente que possa vitimar a sociedade.

Cumpre lembrar que nem sempre efetuar modificações no veículo, adotar caminho mais curto ou imprimir maior rapidez no percurso são propícios a nos conduzir, com sucesso, ao fim da empreita, certo que na obediência aos sinais existentes reside a principal garantia de que isso aconteça.

Isto posto, é hora de seguir, para tratamento específico dos temas "os novos vínculos e as entidades familiares" e "filho - um novo status", com emprego dos paradigmas até aqui assentados. 


\section{CAPÍTULO II. OS NOVOS VÍNCULOS E AS ENTIDADES FAMILIARES}

\section{ENTIDADES FAMILIARES. NOÇÃO}

Por entidades familiares - denominação da Constituição Federal (art. 226) e do Código Civil (art. 1723) -, entende-se, sem discussão, hodiernamente, aquelas decorrentes do casamento e da união estável entre homem e mulher, com ou sem filhos, e aquelas formadas por um dos pais e seus filhos (família monoparental).

Contudo, há um grande número de pessoas que, ligadas por laços afetivos estáveis e publicamente exercidos e reconhecidos, clama por que lhes seja dada a mesma proteção legal já concedida ao grupo acima mencionado, batendo-se o Direito por encontrar resposta a tais situações fáticas cada vez mais recorrentes no dia-a-dia da sociedade.

Assim é que parentes (que não os pais) ou outras pessoas ligadas entre si pela afetividade e não unidas por interesses preponderantemente econômicos (como irmãos órfãos ou abandonados, avós e netos, tios e sobrinhos, padrinhos e afilhados, padrastos e enteados, filhos de criação, indivíduos do mesmo sexo ligados também no aspecto sexual, concubinos, indivíduos de qualquer sexo ligados em caráter estável sem aspecto sexual e até alguns - poucos, é certo - afetuosamente ligados a seus animais de estimação) querem ver reconhecida a tutela seus direitos pela ordem jurídica vigente.

É verdade que a constituição de família não deve ser considerada subjetivamente, mas, antes, tendo-se em conta vários fatores objetivos de formação; caso contrário, ao invés de se proteger tão importante organismo da sociedade o estaríamos colocando em condição de banalização e, conseqüentemente, de aniquilação dos valores nele contidos. 
Há estudos sobre a concepção que o indivíduo tem de família, sendo, nesse campo, o teste do desenho da família bastante difundido entre os psicólogos, onde se busca investigar as relações familiares.

A grande referência do teste do desenho da família é Louis Corman ${ }^{66}$, estudioso francês, pai da morfopsicologia ${ }^{67}$, que propõe que a pessoa desenhe uma família, dentro da maior liberdade para projetar seus estados afetivos, seus desejos, temores atrações e repulsa, propondo um questionário para que o analisando interprete seu desenho, definindo personagens e papéis, identificando os elementos que compõem aquela família.

Muitos estudos sobre o teste do desenho da família estão calcados em interpretações clássicas complexas e mecanismos de defesa, assim como outros testes projetivos. O teste do desenho da família busca o conhecimento do indivíduo e da sua família e a relação que mantém com a mesma no que diz respeito a aspectos conscientes e inconscientes.

Pesquisas procuraram, através dele, observar se determinada amostra apresentaria, nos desenhos, uma família real, isto é, aquela em que efetivamente inseridos os participantes, ou uma família imaginária, como gostariam que a deles fosse. Os testes foram aplicados em pessoas com idades entre 18 a 30 anos, de ambos os sexos, de diversas classes sociais. Os resultados apontaram que 62,5\% da amostra constitui-se de representação gráfica de uma família imaginária, enquanto que apenas $37,5 \%$ dela representa a família real, daí concluindo-se que os sujeitos expressam suas famílias de forma muito diferente daquelas em que estão, na verdade, inseridos $^{68}$.

Ora, se o próprio indivíduo tem grande dificuldade de se posicionar perante o conceito que tem de família ideal e da sua família real, tateando os

${ }^{66}$ O teste do desenho de família, Mestre Jou, São Paulo, 1979.

${ }^{67}$ Segundo a Wikipédia em francês, é o ramo da psicologia segundo o qual cada um de nós é o resultado de uma interação entre o fluir das forças que interiormente o animam e a pressão sobre ele exercida pelo meio exterior, in HTTP://fr.wikipedia.org/wiki/Morphopsychologie, tradução livre do aluno.

${ }^{68}$ FABIO BELLONI, A referência que se tem de família, painel apresentado no I Congresso Latinoamericano da Psicologia, São Paulo, 2005, in http://www.ulapsi.org/cdrom/espanhol/autor_4.php? uid=929\&tipo=PESQ\&codigo=460 [12/03/2009]. 
psicólogos na procura de desvendar o insondável interior da pessoa humana através dos mais diversos meios técnicos, como o conhecido teste acima citado, que não dizer dos legisladores e operadores do Direito (juízes, promotores, advogados), quando instados a, em nome do grupo de indivíduos chamado sociedade, dizer no que se constituem as entidades familiares.

Essa dificuldade se assoma na medida em que o denominado "pluralismo" das entidades familiares faz-se plural não só pelas várias hipóteses da realidade da vida, mas também por todas aquelas outras contidas no inconsciente do indivíduo e, dessa forma, sendo impossível, em nome tão só da isolada aplicação do princípio da dignidade da pessoa humana, reconhecer-se todos os tipos de família porventura imaginados ou imagináveis, necessário se faz delimitar o conceito.

E tal delimitação deve ser alcançada pelo uso do antes já mencionado equilíbrio entre o humanismo, o pragmatismo, e as tensões sociais, numa visão que denominaremos "humanista pragmática ampliada", a saber, humanista porque, na tarefa, ter-se-á em consideração preferencial os interesses e direitos primordiais da pessoa humana; pragmática porquanto não se perderá de vista, para consecução de sucesso na empreita, a conveniência, oportunidade, possibilidade e viabilidade da interpretação e/ou implementação de princípios e normas; e ampliada, por pretender ser, nos seus objetivos, de caráter preponderantemente inclusivo.

Várias são as condições que devem estar presentes para permitir a identificação de um grupo como entidade familiar, entre elas o convívio social (o grupo familiar deve assim apresentar-se e ser visto dentro da sociedade), a efetividade dos liames familiares (não podendo assim ser considerados grupos hipotéticos, virtuais, indeterminados, esporádicos, de afeto livre), e a afetividade (aqui englobadas a "dignidade afetiva da pessoa humana" e a "solidariedade afetiva", antes mencionadas, representativas da prevalência do valor da pessoa humana sobre os valores materiais, patrimoniais, nas relações de família).

Qualquer grupo que pretenda ser considerado como família deve ser formado com tal objetivo, não se incluindo aí relações de amizade, de coleguismo, de sentimento religioso, de auxílio moral e/ou social, de fins eróticos ou, na 
denominação de Sérgio Resende de Barros - em seu artigo "A monetarização do afeto" - de "afeto sexual" 69 .

E mesmo que por qualquer motivo superveniente venha o agrupamento a perder quaisquer das características que lhe concederam identidade familiar (pelo fim da solidariedade, da comunhão de vida, do afeto), a família, como entidade perene que é, permitirá que cada um dos indivíduos, ainda que em fragmentos, seja reconhecido como pertencente àquele determinado grupo familiar, inclusive e em especial para a garantia dos direitos-deveres decorrentes desse liame.

Esse, aliás, um dos objetivos do regramento constitucional ao impor como dever à família, à sociedade e ao Estado o cuidado de seus membros (em especial crianças, idosos e deficientes), certo que a família referida na Carta Constitucional é aquela considerada na sua formação original, inclusive para o fim de assistência no caso de iniciar-se processo de sua desintegração, até para estancá-lo e, se possível, revertê-lo ou, quando não, minorar seus efeitos.

Há uma verdadeira relação de interdependência da família, enquanto grupo social diferenciado, e cada uma das pessoas humanas que a constituem, enquanto membros de uma entidade familiar específica, indo contra o espírito da Constituição Federal colocar a entidade familiar como mero instrumento de realização egoística do indivíduo.

O reconhecimento social de um agrupamento como entidade familiar não pode se dar por um capricho individualista de pessoas que jamais tiveram intenção de agir como parte de um todo, embora exigindo que o todo os considere como parte dele integrante.

Devem ser evitadas as arapucas armadas por aqueles que, sem se importar com o peso a ser suportado em decorrência da condição de pilar social (pois que é a família base da sociedade), desejam obrigar, aos que o assim fazem, suportarem,

\footnotetext{
${ }^{69}$ In Revista do Instituto de Pesquisas e Estudos da Instituição Toledo de Ensino, Bauru, n. 33, dez. 2001 a mar. 2002, p. 465.
} 
mais, a carga adicional decorrente da excessiva e desmedida ampliação do conceito de entidade familiar àqueles agrupamentos não perfeitamente identificados com ela.

Os preceitos constitucionais não podem ser objeto de tergiversação, ora válidos, ora inválidos (ou, como na interpretação de alguns doutrinadores, indeterminados, abertos, dúcteis, adaptáveis ${ }^{70}$, quando se trata de justificar o rompimento de todas as linhas sociais democraticamente traçadas, dos quais, respeitosamente, temos que discordar, ainda que em parte).

Nosso posicionamento é de que, ainda que tocados por ares liberais e de compreensão e solidariedade humana, temos que respeitar o sentimento da maioria da sociedade, que vive sob regras por ela mesma impostas, e que somente com a utilização de instrumento legal equivalente podem ser parcial ou totalmente modificadas.

Vamos trabalhar uma situação concreta muito comum, com objetivo de melhor situarmos nossa posição no assunto.

Todos nós temos noções de higiene social e de regras básicas a serem obedecidas em todos os locais públicos para a necessária satisfação das necessidades fisiológicas.

Pois bem, há banheiros masculinos e femininos, separados, em todo e qualquer local público ou de acesso público. O que motiva sua criação apenas para os dois mencionados sexos e o que impede seu uso sem observância das suas especiais destinações? Não seria tal sistema discriminatório, excludente, ofensivo à dignidade da pessoa humana? Não se deveria dar prioridade à necessidade premente do desafogo fisiológico sobre regras sociais de convivência? Não seria justo exigir a criação de um terceiro banheiro (ou um quarto, ou quinto etc.), para as pessoas que não se sentem incluídas quer em uma quer em outra das denominações sexuais existentes?

\footnotetext{
${ }^{70}$ Como se encontra, por exemplo, em PEDRO LUIZ NETTO LÔBO, Famílias cit. (nota 31 supra), p.
} 61. 
De fato, há regras impostas pela sociedade, que entende, pela maioria, ser suficiente a oferta de banheiros separados para pessoas do sexo masculino e feminino, necessária mesmo para se evitar promíscuo contato de crianças, que do serviço se utilizem, com adultos do sexo oposto, e mesmo a importuna exposição da intimidade de homens e mulheres entre si, sem que assim seja do seu desejo, em nada confortando à coletividade eventual "interpretação inclusiva" que permita uso misto dos sanitários públicos.

E veja-se ser conceito social tão arraigado que mesmo os estabelecimentos comerciais, embora não obrigados a tal, procuram oferecer dessa mesma forma esse serviço essencial.

Ainda que para alguns pareça estranha ou mesmo forçada a abordagem, há vários projetos de lei, nos âmbitos municipal, estadual e federal tratando do assunto, e os argumentos utilizados nas respectivas justificações ligam diretamente e sem rodeios os temas. Há, por exemplo, projeto do vereador Augusto Serra, de São Luis do Maranhão, que pretende criar banheiros para gays e transexuais em espaços públicos da capital maranhense, aduzindo que "vamos acolher esta classe social. Estamos observando uma grande tendência para o casamento de pessoas do mesmo sexo, então, cada vez que a sociedade avança as leis têm que acompanhar" ${ }^{71}$.

Na esfera federal, projeto de lei sob n. 1565/07, de autoria da Deputada Andreia Zito, nele apensos mais quatro projetos posteriores tratando da mesma matéria, que dispõe sobre a obrigatoriedade de banheiros públicos em agências bancárias, obteve voto favorável do relator Deputado Simão Sessim, onde é utilizado argumento que, sem maior esforço, já se pode antever qual seja - oferecer aos usuários "um mínimo de dignidade, na forma de instalações sanitárias adequadas", estabelecendo o substitutivo ofertado pelo referido relator que "os banheiros ... deverão ser separados por sexo".

Assim se constata que a sociedade e seus representantes, a par do que queiram fazer valer a minoria e a doutrina de vanguarda, pensam e agem, a começar

\footnotetext{
${ }^{71}$ In http://www.acapa.com.br/site/noticia.asp? codigo $=680,[13-03-2009]$
} 
das mais primitivas necessidades humanas, dessa maneira. Há pudores sociais, há regras sexuais de convivência, há a preocupação moral, com inevitáveis reflexos legais, quanto aos conceitos formadores da consciência coletiva.

Muitos rumos da humanidade foram e continuam a ser dados por exemplos tirados da vida. O indivíduo, como ser social, procura portar-se como o homem médio, e a sociedade dele também espera que assim o faça.

E o homem médio nasce e cresce numa família com pais e irmãos, rodeado por outros parentes, cresce orientado para interagir positivamente com o grupo familiar, dele recebendo e a ele prestando suporte, até adquirir independência financeira suficiente para ter sua própria casa, cônjuge e prole, enfim, constituir um novo núcleo familiar, na perpetuação de um círculo virtuoso que mantém viva a própria sociedade.

Há hipóteses diferentes da descrita? É lógico que há várias, mas isso não obriga à sociedade tratar de todas elas, ou melhor, ainda que tenha todo indivíduo direito à análise seus interesses, isso não quer dizer que todo pleito é passível de ser acolhido legalmente pela sociedade.

Eventual recepção de hipóteses não elencadas na lei deve ser buscada através de instrumentos legislativos adequados, como, por exemplo, a Proposta de Emenda à Constituição (PEC) apresentada pelo Senador Sérgio Cabral, que tomou o n. 70/2003, com objetivo de alterar o parágrafo $3^{\circ}$ do artigo 226 , da Constituição Federal, para permitir a união estável entre casais homossexuais, proposta essa que, entretanto, foi retirada pelo autor, em 05/10/2006, com arquivamento do processo.

Já o Ministro Celso de Mello, do STF, destacou, na ADI 3300 MC/DF, em 03/02/2006, processo extinto sem julgamento de mérito proposto pela Associação Parada do Orgulho Gay - que postulava inconstitucionalidade da definição legal de união estável contida nas normas vigentes -, ser "relevantíssima questão constitucional" a discussão sobre o reconhecimento da legitimidade constitucional das uniões homossexuais e de sua qualificação como entidade familiar, que deveria 
ser tratada, contudo, segundo o citado ministro, via ADPF, razão, aliás, da extinção decretada.

E, atualmente, no assunto, corre perante o Supremo Tribunal Federal Argüição de Descumprimento de Preceito Fundamental (ADPF), sob n. 25832, com entrada em 27/02/2008, em que são argüintes o Governador do Estado do Rio de Janeiro e argüidos os Tribunais de Justiça dos Estados e a Assembléia Legislativa do Estado do Rio de Janeiro, tendo como interessados admitidos a Conectas Direitos Humanos, o Escritório de Direitos Humanos do Estado de Minas Gerais, o Grupo Gay da Bahia, o Grupo de Estudos em Direito Internacional da Universidade Federal de Minas Gerais, o Centro de Referência de Gays, Lésbicas, Bissexuais, Travestis, Transexuais e Transgêneros do Estado de Minas Gerais, o Centro de Luta pela Livre Orientação Sexual, a Associação de Travestis e Transexuais de Minas Gerais, o Grupo Arco-Íris de Conscientização Homossexual, a Associação Brasileira de Gays, Lésbicas, Bissexuais, Travestis e Transexuais e o Instituto Brasileiro de Direito de Família, cujo desfecho, entretanto, está distante.

Assim, enquanto não apreciada ou modificada a matéria nos âmbitos legislativo ou judiciário, continua a dignidade da pessoa humana sendo trazida como elemento vital na análise da questão. Mas não deve ela vir só, pois também merece igual destaque a dignidade das pessoas humanas em um agrupamento (ou seja, a dignidade da sociedade).

Resta, então, decidir o que fazer quando se dá o inevitável confronto de tais dignidades e, desde logo, aponto ser correto afirmar que um conjunto de dignidades prevalece sobre a dignidade de um só, ou de uma minoria, merecendo menção, em abono da conclusão ora tirada, posições doutrinárias quanto à solução a ser dada na ocorrência de conflito de normas constitucionais.

Canotilho, enfrentando a questão, inicia distinguindo entre concorrência e colisão de direitos fundamentais, sendo que se dá a primeira quando um comportamento do mesmo titular preenche os pressupostos de fato de vários direitos fundamentais. Por sua vez, "considera-se existir uma colisão autêntica de direitos fundamentais quando o exercício de um direito fundamental por parte do seu titular 
colide com o exercício do direito fundamental por parte de outro titular. Aqui não estamos perante um cruzamento ou acumulação de direitos (como na concorrência de direitos), mas perante um 'choque', um autêntico conflito de direitos" ${ }^{\text {,72. }}$.

Nessa última hipótese, o constitucionalista luso adverte sobre " $a$ necessidade de as regras do direito constitucional de conflitos deverem construir-se com base na harmonização de direitos, e, no caso, de isso ser necessário, na prevalência (ou relação de prevalência) de um direito ou bem em relação a outro (D1 P D2). Todavia, uma eventual relação de prevalência só em face das circunstâncias concretas se poderá determinar, pois só nestas condições é legítimo dizer que um direito tem mais peso do que o outro (D1 P D2)C, ou seja, um direito (D1) prefere (P) outro (D2) em face das circunstâncias do caso (C),73.

Recentemente, o Supremo Tribunal Federal pronunciou-se sobre o assunto, em rumoroso caso envolvendo cantora mexicana aqui detida aguardando extradição, que teria sido estuprada por agentes públicos e engravidado na prisão.

Fez-se, ali, ponderação dos valores constitucionais contrapostos, quais sejam, o direito à intimidade e à vida privada da extraditanda, e o direito à honra e à imagem dos servidores e da Polícia Federal como instituição - atingidos pela declaração de a extraditanda haver sido vítima de estupro carcerário, divulgada pelos meios de comunicação -, negando-se, então, pedido da presa no sentido de ser impedida a coleta de material de sua placenta, após o parto, para exame de DNA, afirmando-se a prevalência do esclarecimento da verdade quanto à participação dos policiais federais na alegada violência sexual, levando-se em conta, ainda, que o exame de DNA acontecerá sem invasão da integridade física da extraditanda ou de seu filho ${ }^{74}$.

Todas essas considerações são de molde a nos obrigar a uma detida reflexão sobre quais grupos e pessoas efetivamente podem ser considerados incluídos na expressão constitucional “entidade familiar", passando longe dos caminhos fáceis,

\footnotetext{
${ }^{72}$ Direito Constitucional... cit. (nota 53 supra), p.1189 e 1191.

${ }^{73}$ Direito Constitucional... cit. (nota 53 supra), p. 1194.

${ }^{74}$ RCL 2.040-DF, rel. Min. Néri da Silveira, 21.2.2002, Informativo n. 257, do STF.
} 
de um lado, da simples e pura aceitação de nela incluir todos os detentores de direitos fundamentais, indistintamente (até porque, como antes dito, mesmo aos animais estão sendo eles conferidos) e, de outro, da absoluta negativa a qualquer grupo que não aqueles literalmente elencados na Constituição brasileira.

E lançando olhos, então, sobre a sociedade atual, reconhecemos nela a família matrimonial (a mais comum, padrão, de casados), a informal (de conviventes em união estável), a monoparental (formada por um dos pais e seus filhos); a anaparental (sem pais), e a pluriparental (também denominada reconstituída, recomposta, ou mosaico, formada por novos enlaces em que pelo menos um dos envolvidos tem prole anterior).

Merecem menção, igualmente, as relações concubinárias (decorrentes de relacionamentos concomitantes) e as homoafetivas (entre pessoas do mesmo sexo) que, conquanto nesse estudo não sejam consideradas como entidades familiares, são reconhecidas para geração de vários efeitos legais, conforme, aliás, vem se decidindo nas instâncias superiores ${ }^{75}$.

Firmando o que já foi dito, constata-se que o Código Civil de 1916 nasceu como norma fundante do Direito Privado (assim como seu sucessor, de 2002, pretendeu ser), mas sua desatualização provocou o surgimento de microssistemas, que terminaram por minar a articulação interna desses códigos, a isso se somando o novo conteúdo trazido na Constituição de 1988 e nos tratados internacionais, a reclamar reestrutura e reorganização lógica do sistema, em especial na questão das entidades familiares.

Os direitos fundamentais são, nessa tarefa, como anota Lorenzetti, "piso mínimo inderrogável'. Porém, como competem entre si, esta colisão requer uma visão ampliada, capaz de fazer-nos escolher os mais adequados entre os de possível aplicação, bem como a formação de uma base suficiente para dar efetividade a esses,

\footnotetext{
${ }^{75}$ Sobre concubinato, entre vários, dois julgados do STJ, 4 ${ }^{\mathrm{a}}$ T. : REsp 229.069/SP, rel. Min, Fernando Gonçalves, j. 26/04/2005; e REsp 303.604/SP, rel. Min. Aldir Passarinho Junior, DJU 23/06/2003); sobre união homossexual, entre outros, TJRS, $7^{\text {a }}$ Câm. Civ., AC 70001388982, rel. Des. José Carlos Teixeira Giorgis, j. 14/03/2001.
} 
a fim de, não serem reduzidos a "meras declarações", do que necessitam "ser compatibilizados com a ordem social",76.

E, nesse passo, surge, como lupa, a afetividade.

\section{AfETIVIDADE}

Parece elementar que o sentimento de afeto esteja presente, como elo, entre casais e entre genitores e seus filhos.

Contudo, o estudo da ideologia da família patriarcal, de herança romana, como originariamente concebida, mostra situação diversa. Nela, a cidadania plena concentrava-se na pessoa do paterfamilias, dotado de direitos exclusivos e absolutos, devendo-lhe estrita obediência a mulher e os filhos. O espaço privado familiar era imune à intervenção pública, nele dando-se subjugação e abusos contra seus integrantes.

A idéia de que o agrupamento familiar tinha como função principal a manutenção da sua força econômica, como forma de perenizá-lo, ditava as diretrizes do comportamento do chefe da família.

Tal modelo, conquanto mitigado nos seus exageros pelo cristianismo, foi adotado amplamente por todas as sociedades, que passaram a ver a família nuclear como sua base, tratando o indivíduo desengajado de sua família como um desafortunado destituído de direitos. A visão biológica e patrimonialista do núcleo familiar se fez e se faz, nesses tempos, fortemente presente.

Nessa medida, em contraponto, passa-se a falar em repersonalizar a família, ou seja, lançar olhos à sua raiz antropocêntrica ${ }^{77}$ - trazer de volta a importância do indivíduo às relações de família, dentro do inigualável elo do afeto.

Esse fenômeno, da "repersonalização do direito, é acatado integralmente por nossa ordem jurídica. Não se precisa ir longe para verificá-lo. Basta notar que o

\footnotetext{
${ }^{76}$ Fundamentos... cit. (nota 39 supra), p. 280.

${ }^{77}$ LUC FERRY anota que “. .. a filosofia moderna é uma filosofia do 'sujeito', um humanismo, e até mesmo um antropocentrismo, quer dizer, no sentido etimológico, uma visão do mundo que coloca o homem (anthropos, em grego) - e não o cosmos ou a divindade - no centro de tudo.", in Aprender... cit. (nota 19 supra), p. 164.
} 
legislador constitucional estabeleceu que a dignidade da pessoa humana é um dos fundamentos da República." ${ }^{, 78}$.

O tema "repersonalização", aliás, não deve ser confundido com o da discussão entre personalização e institucionalização da família, questão essa atinente ao debate sobre constituir a família pessoa jurídica especial ou instituição, tratada por Rui Geraldo Camargo Viana em estudo a respeito do assunto onde, após apresentar os posicionamentos existentes, confessa que "como se vê, tal qual a esfinge, permanece a família como conceito indecifrado pelo Direito."79.

De qualquer forma, como pondera Paulo Luiz Netto Lôbo, não é questão de importância atribuir-se personalidade jurídica à família, para os efeitos pretendidos pelo Direito ${ }^{80}$. Qualquer que seja o enfoque (sujeito de direito não personalizado; parte de ofício; personalidade incompleta; simples capacidade de direito processual ou legitimação), o importante é reconhecer à família, na forma da novel ordem constitucional, responsabilidade jurídica pelos deveres que tem perante seus membros.

Por isso mesmo, contemporaneamente, em atenção ao princípio da dignidade da pessoa humana, tenta-se, com inúmeras dificuldades, estabelecer um equilíbrio entre o público e o privado, com maior intervenção do Estado na garantia dos direitos fundamentais, especialmente no concernente à família, embora a realidade que encontremos no meio social seja, ainda, de grande desrespeito ao indivíduo, em especial ao menor, mercê de uma renitente cultura de séculos.

Nos primórdios da humanidade, os laços que uniam os membros de uma família eram principalmente afetivos, construídos sob o primado da liberdade e do desejo e tais razões voltaram a ter importância social superior àquelas de ordem puramente biológica, matrimonial e patrimonial, na esteira das perplexidades que brotam, a cada momento, dos avanços científicos no campo da inseminação artificial, onde um indivíduo pode ter, geneticamente, elo natural com múltiplos geradores envolvidos no processo, a par do elo legal com outros tantos que não necessariamente os seus reprodutores, assim como quanto às cirurgias de

\footnotetext{
${ }^{78}$ EROUTHS CORTIANO JÚNIOR, O Direito de Família no projeto do Código Civil, in Arruda Alvim Wambier e Eduardo de Oliveira Leite (coord.), Repertório de doutrina sobre Direito de Família-aspectos constitucionais, civis e processuais, vol. 4, São Paulo, RT, 1999, p. 230.

${ }^{79}$ A família cit. (nota 8 supra) p. 40-48.

${ }^{80}$ A repersonalização das relações de família, in Revista Brasileira de Direito de Família, Ano VI, n. 24, Porto Alegre, Síntese, jun-jul 2004, p. 155.
} 
modificação externa da aparência sexual e pedidos de mudança de nome e sexo no registro de nascimento e suas conseqüências nas ligações afetivas tanto heterossexuais quanto homossexuais.

Os doadores de sêmen e óvulos, as mães "de aluguel", as técnicas de clonagem, a incrível possibilidade de reprodução a partir de células de duas mulheres ou da implantação de embrião em órgão masculino que passaria a fazer o papel de útero, e homens e mulheres que têm sua fisiologia sexual alterada, deixaram de ser temas de livros e filmes de terror ou de ficção científica para fazerem parte da nossa realidade, com geração e transformação de seres humanos sujeitos de direitos e obrigações, dos quais deve ocupar-se a lei de forma satisfatória, na missão de lhes definir quem são eles, quem são seus pais, qual é a sua família, ou, antes, garantirlhes o próprio direito à personalidade.

Naturalmente, no estrito âmbito desta pesquisa não caberá falar, em minúcias, de todos esses tormentosos aspectos, alguns citados e comentados, porém, como forma de se destacar a importância que passou a ter o elemento afetivo no estabelecimento da ligação entre indivíduos e entre pais e filhos.

Seria como negar a luz ignorar a existência de pessoas do mesmo sexo vivendo em caráter estável, solidário, com comunhão de vidas e interligadas por afeto mútuo, merecendo tal realidade uma resposta efetiva do legislador e do operador do Direito.

Também não mais parece adequado serem considerados pais aqueles simplesmente assim determinados biologicamente, mas sim deve atentar-se à existência de um especial elo ligando tais pessoas à do filho, formado esse elo por um particular desejo de terem consigo a prole, de repartirem com ela, com qualidade, o período de tempo disponível para usufruto nos atos da vida particular, de participarem ativamente da solução dos problemas comuns da vida do filho, na criação, educação, saúde e lazer, com objetivo de formar aquele indivíduo para o mundo.

Em suma, é desejável ampla intimidade familiar, na acepção mais pura da palavra; devem procurar os integrantes de um casal, os pais, os filhos, ter dentro de si, no seu íntimo, a vontade, a certeza, o prazer de poderem contar uns com os outros, deve existir amor. 
Silvana Maria Carbonera aborda com propriedade o assunto em artigo específico, onde conclui que "o vínculo jurídico, representado pelo casamento, passou a ser insuficiente para manter duas pessoas juntas. $"{ }^{\prime}$.

Destaca Sérgio Resende de Barros que “o direito ao amor é a máxima expressão do direito ao afeto. O amor é a substância e a culminância do afeto. Não se desenvolve um sem o outro. O mais puro afeto é o amor. O amor faz do indivíduo um ser humano. Identifica os entes humanos, uns com os outros, tão fortemente, que gera em todos nós a solidariedade humana, que é a única força capaz de construir dignamente - a humanidade em toda a humanidade, a partir de seu grupo inicial: a família. E repita-se: não só construir, mas assegurar a humanidade construida, o que é o fim próprio dos direitos humanos. ${ }^{\prime 82}$.

Não podemos olvidar, contudo, que, conquanto fator de importância, não é essencial o amor para dar liga à massa que une de forma permanente o grupo familiar. Pueril, aliás, seria fulcrar a questão toda nesse sentimento e simplesmente aguardar que dali brotasse, íntegra, a entidade familiar.

A formação de um grupo familiar exige coisa diversa. Clama, sim, por uma "afetividade especializada",83, uma relação socioafetiva socialmente reconhecida, com caráter estável e comunhão de vida, a par dos tradicionais elos patrimoniais e biológicos também eventualmente presentes.

Através dela se alcança e se justifica a verdadeira igualdade entre homem e mulher e entre filhos e por ela se realizam os mais altos desígnios da entidade familiar, pois a afetividade "é dever imposto aos pais em relação aos filhos e destes em relação àqueles, ainda que haja desamor ou desafeição entre eles" e entre cônjuges e companheiros, enquanto estiverem essas pessoas unidas "com objetivo de constituição de família", cessando somente com a morte, a perda do poder familiar ou o desenlace do casal, nesse último caso restando efeitos "como a prestação de alimentos e o dever de segredo sobre a intimidade e a vida privada" ${ }^{84}$.

É árdua tarefa que toca aos operadores do Direito a de exercer a defesa da integridade da família, propiciando os meios jurídicos necessários à formação sadia

\footnotetext{
${ }^{81}$ O papel jurídico do afeto nas relações de família, in Luiz Edson Fachin (coord.), Repensando fundamentos do Direito Civil brasileiro contemporâneo, Rio de Janeiro, Renovar, 2000, p. 297.

${ }^{82}$ Direitos Humanos... cit. (nota 11 supra), negritos do original.

${ }^{83}$ Famílias cit. (nota 31 supra), p. 48.

${ }^{84}$ Famílias cit. (nota 31 supra), p. 48-49.
} 
dos vínculos familiares, bem como sua manutenção quando as atribulações da vida os vêm pôr em risco.

E a igualdade constitucionalmente implantada entre homem e mulher e entre filhos, a repersonalização da família ${ }^{85}$ e o prestígio ao princípio da afetividade são, seguramente, instrumentos úteis e necessários ao alcance de tal desiderato.

Porém, ser família, como antes já lembrado, não é um privilégio, do qual resultam apenas regalias legais; é, certamente, um conjunto de direitos-deveres determinados pela sociedade ao estabelecer àquela, expressamente, como função, ser sua base, assunto que será, na seqüência, enfrentado.

\section{DiREITOS-DEVERES: A FUNÇÃO SOCIAL DA FAMÍLIA}

A formação de um núcleo familiar, como é evidente, não traz para os seus membros somente as benesses advindas do reconhecimento social desse grupo como tal, mas também obrigações legais naqueles aspectos em que se espera devam seus integrantes interagir de modo a propiciar o que de melhor a cada um dos indivíduos que ali estão em relação de interdependência, não só liberando o Estado de excessivo assistencialismo, como também exercendo em plenitude seu papel de unidade de renda e de consumo, mantendo-se através do trabalho individualizado de seus membros, cumprindo, assim, suas tarefas de se fazer reconhecida como tal perante a sociedade (função institucional), ser geradora de condições de vida do grupo familiar (função socioeconômica), de ser referência (valor) para aquele grupo de indivíduos entre si (função afetiva especializada).

Tanto no campo material quanto no espiritual, as funções das entidades familiares se fazem indispensáveis, destacando-se "a função de espaço de afetividade e da tutela da realização da personalidade das pessoas que as integram; em outras

\footnotetext{
85، A família, ao converter-se em espaço de realização da afetividade humana e da dignidade de cada um de seus membros, marca o deslocamento da função econômico-político-religiosa-procracional para essa nova função. Essas linhas de tendência enquadram-se no fenômeno jurídico-social denominado repersonalização das relações civis, que valoriza o interesse da pessoa humana mais do que suas relações patrimoniais. O anacronismo da legislação sobre família revelou-se em plenitude com o despontar dos novos paradigmas das entidades familiares. O advento do Código Civil de 2002 não pôs cobro ao descompasso da legislação, pois várias de suas normas estão fundadas nos paradigmas passados e em desarmonia com os princípios constitucionais referidos". A repersonalização... cit. (nota 80 supra) p. 54-55.
} 
palavras, o lugar dos afetos, da formação social onde se pode nascer, ser, amadurecer e desenvolver os valores da pessoa." $"$

A liberdade, a justiça e a solidariedade, estampadas no artigo $3^{\circ}$, inciso I, da Constituição Federal, são seguros indicativos do caminho que deve trilhar o grupo que pretenda intitular-se como familiar, a par dos vínculos de sangue, de direito e de afeto que possam existir.

Esses princípios constitucionais, entre outros - como antes tivemos oportunidade de analisar - são exaustivamente utilizados pela atual doutrina para justificar a mais ampla conceituação de entidade familiar.

Igual importância, contudo, não é dada à expressão "base da sociedade", empregada na Constituição para definir a família, não se encontrando na doutrina uma análise mais aprofundada do que isso efetivamente signifique em termos de identificação de um grupo como tal, preferindo os autores dar destaque para "direitos fundamentais", "direitos humanos", "princípios constitucionais" e outros do gênero, ficando relegada a impar função de "base da sociedade" à categoria de um distintivo constitucional sem maior relevância na conceituação própria.

Nossa visão do assunto é, nesse passo, diversa.

Temos convicção de que, além dos importantes fatores, sempre mencionados, da dignidade da pessoa humana, da solidariedade, da igualdade, da liberdade, da afetividade, o fator de conformação social está indissoluvelmente ligado ao conceito de entidade familiar e deve ele ser levado em consideração para se alcançar - não só por elementos jurídico-filosóficos, mas também por dados concretos do que seja essa "base da sociedade" - um conceito jurídico útil de entidade familiar.

Para tal fim, é mister fazer, ainda que de forma sucinta, análise dos últimos dados estatísticos atinentes à população brasileira, em especial no que toca à família.

Várias modificações vêm sendo observadas, nos últimos censos demográficos do IBGE, nas condições de reprodução da população, com diminuição da fecundidade e da mortalidade infantil e adulta; no aumento do percentual de

\footnotetext{
${ }^{86}$ Famílias cit. (nota 31 supra), p. 60.
} 
idosos, proporcionado por melhores condições de vida e saúde; nos padrões de relacionamento entre os membros da família; e no papel da mulher dentro e fora do espaço doméstico.

A história dos censos, que começa em 1872, quando realizado o pioneiro, e que alcança até o último, do ano de 2000, assim como a recente síntese de indicadores sociais do IBGE, de $2008^{87}$, apontam para um país ainda hoje com quase 90\% da população de religião católica ou evangélica, que passa por progressivo envelhecimento populacional (cuja pirâmide etária, até 2050, estará praticamente invertida), com taxa de fecundidade decrescente.

Informa-se que a família "unipessoal" (pessoas vivendo sozinhas) representa, no universo familiar, 11,1\%; a família “com parentesco" 88,6\% (considerada a consangüinidade, sendo quase metade dessa com filhos); e a família "sem parentesco" apenas $0,3 \%$ do total.

Das famílias com filhos menores de 16 anos, 78,2\% são de casais, e $21,8 \%$ monoparentais (dessas últimas 90,2\% sendo monoparentais femininas).

A taxa de nupcialidade legal denota crescimento, superando índices de dez anos atrás, apontando o casamento ainda como a forma mais utilizada na formação da família, sendo que, nesse conjunto, os casamentos exclusivamente entre solteiros vêm declinando, na mesma proporção em que aumentam aqueles entre solteiros, viúvos e divorciados e entre esses últimos.

No desenlace, as separações consensuais são $76 \%$ e as judiciais $24 \%$ do total, sendo que a guarda dos filhos é atribuída à mãe em $90 \%$ dos casos.

Esses dados mostram claramente que a família, embora passando por efetivas transformações, não é exatamente aquela que as interpretações mais liberais pretendem fazer crer esteja cristalizada, antes se percebendo que o casamento entre homem e mulher permanece amplamente prestigiado, dentro de uma visão religiosa predominantemente cristã, com formação principal dentro de vínculos de consangüinidade, representando avanço a aceitação dos divorciados para novo enlace legal.

\footnotetext{
${ }^{87}$ Síntese de Indicadores Sociais, uma análise das condições de vida da população brasileira 2008, in Estudos \& Pesquisa, Informação demográfica e socioeconômica n. 23, IBGE, Rio de Janeiro, 2008.
} 
Indica, outrossim, que o Estado deve passar a se preocupar com o constante declínio da taxa de fertilidade e conseqüente aumento da idade populacional que, em alguns anos, causarão problemas nos setores econômicos, previdenciários e de saúde; deve ser dada atenção, igualmente, ao aumento do número de famílias monoparentais que, pela própria estrutura, demanda maior assistência governamental.

É dever do Estado, igualmente, continuar dando instrumentos de proteção à mulher separada e divorciada com filhos, pois é essa quem continua principal responsável pela prole ao fim da vida em comum do casal.

Essas constatações da realidade da sociedade brasileira devem dar o tom das políticas públicas a serem adotadas quanto à fixação da conceituação legal das entidades familiares, e quanto ao estabelecimento dos direitos e deveres a elas tocantes.

Já se faz longe o tempo dos feudos e a função social da propriedade está hoje bem compreendida, ainda que muitas desinteligências ainda aconteçam na aplicação das leis sobre o tema.

Pergunta-se quanto tempo levará até que se aceite a função social da família, deixando-se de tratá-la como um feudo fechado pertencente a grupos que, nele, podem fazer o que entenderem melhor.

Reduzir a entidade familiar a um núcleo duro, impermeável, sem interligação com a sociedade que, como base, deve sustentar, é decretar a morte da família ou, no menos, abrir campo para que a sociedade termine por eleger para si outra base de sustentação.

A entidade familiar é, sem dúvida, ponto de referência do indivíduo, onde ele nasce, cresce, desenvolve a afetividade e se socializa (através do aprendizado moral e intelectual).

Mas é mais que isso; continua, inegavelmente, a ter importância econômica, pelo apoio material entre seus membros e pela transferência patrimonial hereditária; e, embora relativizada em sua essência, permanece, além de porto seguro para a plena satisfação afetiva e sexual, como eficiente centro de procriação, onde aos indivíduos ali nascidos são garantidos os acima citados meios materiais e 
espirituais postos a seu serviço, até que tenham forças próprias para constituir novo núcleo familiar.

Negar à entidade familiar o exercício tais direitos-deveres é como querer defender que a propriedade possa ser de utilizada sem qualquer preocupação social, deixando a terra infértil, improdutiva, por escolha própria dos que ali vivem, ou dando a ela destinação diversa daquela esperada e legalmente imposta pela sociedade.

Antônio Chaves leciona que a "união de dois seres é muito mais complexa do que parece à primeira vista, revelando-se base e origem de um instituto também ético, jurídico, social, e até mesmo político, o mais importante de todos, pois é nessa união que o Estado assenta a sua base, como célula fundamental da própria continuidade de seus componentes" ${ }^{\prime \prime}$.

Prestar especial enfoque à entidade familiar não significa, naturalmente, retirar aos indivíduos, vistos individualmente, quaisquer direitos fundamentais (ou humanos, como se queira), mas indica que, dentro de uma ordem social, há eleição de prioridades e imposição de regras para garantir o seu alcance.

A Constituição, no seu artigo 226, caput, combinado com seu $\S 3^{\circ}$, estabeleceu como requisito necessário ao reconhecimento de união estável como entidade familiar a diversidade de sexo do par, certo que, quanto ao casamento, sequer cogitou o constituinte de 1988 ser preciso destacar, nesse âmbito maior, igual exigência, tal parecia ser a sua obviedade.

É o que se extrai, aliás, da simples leitura conjunta do caput e parágrafo citados, da qual resulta, ainda, a clara conclusão de que a "família" referida na cabeça do artigo é a decorrente do "casamento" (mencionado no parágrafo), essa merecendo a original "especial proteção do Estado", sendo que se estendeu a referida proteção especial à união estável, através de expresso reconhecimento dessa também como entidade familiar.

Todavia, passados mais de vinte anos da promulgação da nossa Carta, já se levantam muitas vozes contra tal norma, apontada, em especial pelos baluartes da

\footnotetext{
${ }^{88}$ Falsidade ideológica decorrente do registro de filhos alheios como próprios - Pode a sociedade punir um ato cuja nobreza exalça?, in Revista da Faculdade de Direito, vol. LXXII, 2º . Fasc., 1977, p. 87.
} 
família homoafetiva, como violadora dos princípios fundamentais contidos na própria Lei Magna.

Porém, ainda que aceitáveis - para discussão acadêmica - os argumentos liberatórios, fato inafastável é o de que não cabe, no Direito brasileiro, declaração de inconstitucionalidade de norma constitucional, em obediência ao princípio da unidade hierárquico-normativa da Constituição, devendo ser os eventuais choques de dispositivos resolvidos através do exercício da já citada "relação de prevalência",89 entre os direitos envolvidos, por ponderação e concordância entre esses.

Não se podendo cogitar, então, de normas constitucionais originárias inconstitucionais, é decorrência o afastamento das teses que, por tal ângulo, visam fulminar os dispositivos legais, tanto constitucionais quanto infraconstitucionais, que atribuem determinados direitos (e deveres, lembre-se) expressamente ao casal formado por pessoas de distintos sexos (como nos artigos 226, $\S \S 3^{\circ}$ e $5^{\circ}$, da Constituição Federal e 1517, caput, 1565, caput, 1567, caput, 1642, caput e 1689, caput, todos do Código $\mathrm{Civil}^{90}$ ), pelo menos até que obtenham seus defensores o apoio de $3 / 5$ do Congresso Nacional.

Enquanto tal não ocorre, é justo garantir aos grupos de indivíduos que não se enquadram na definição legal de entidade familiar respeito às suas destacadas dignidade, igualdade e liberdade, reconhecendo suas ligações afetuosas através dos regramentos já existentes - da sociedade de fato - e, embora não recepcionados pelo Direito de Família, a eles sejam garantidos direitos de natureza patrimonial (que já vem a eles sendo dados por aplicação analógica da Súmula 380, do STF, mesmo caminho trilhado, por longo período, pelos então chamados "concubinos"), bem

${ }^{89}$ Direito Constitucional... cit. (nota 53 supra), p. 1194.

${ }^{90}$ Art. 226 - A família, base da sociedade, tem especial proteção do Estado.

... $\S \mathbf{3}^{\mathbf{0}}$ - Para efeito da proteção do Estado, é reconhecida a união estável entre o homem e a mulher como entidade familiar, devendo a lei facilitar sua conversão em casamento.

$\ldots \S \mathbf{5}^{\circ}$ - Os direitos e deveres referentes à sociedade conjugal são exercidos igualmente pelo homem e pela mulher.

Art. 1.517. O homem e a mulher com dezesseis anos podem casar, exigindo-se autorização de ambos os pais, ou de seus representantes legais, enquanto não atingida a maioridade civil.

Art. 1.565. Pelo casamento, homem e mulher assumem mutuamente a condição de consortes, companheiros e responsáveis pelos encargos da família.

Art. 1.567. A direção da sociedade conjugal será exercida, em colaboração, pelo marido e pela mulher, sempre no interesse do casal e dos filhos.

Art. 1.642. Qualquer que seja o regime de bens, tanto o marido quanto a mulher podem livremente:

Art. 1.689. O pai e a mãe, enquanto no exercício do poder familiar:

$\ldots$ 
assim de ordem previdenciária (conforme já lhes vem sendo reconhecido através da Instrução Normativa INSS/DC 118, de 14/04/2005, publicada no DOU de 18/04/2005, que, em seu artigo 30 dispõe que o companheiro ou a companheira homossexual de segurado inscrito na providência passa a integrar o rol dos dependentes, tendo direito à pensão por morte e ao auxílio-reclusão).

Bastante divulgado, de outra parte, o Projeto de Lei 1151/95, de autoria da então Deputada Federal Marta Suplicy, que visa instituir a parceria civil registrada entre pessoas do mesmo sexo e aguarda há anos andamento, retirado que foi da pauta em 2001 por acordo de lideranças, e agora conta com o requerimento $n^{\circ} 1447 / 2007$, do Deputado Celso Russomanno, que solicita sua reinclusão na ordem do dia, pedido esse, por sua vez, que também já aguarda há quase dois anos apreciação, do que se pode ter noção das imensas dificuldades enfrentadas pelo tema (ainda que, para não padecer de inconstitucionalidade no nascedouro, sequer se tenha nele ventilado estender possibilidade de se reconhecer como entidade familiar o arranjo entre homossexuais) ${ }^{91}$.

Resta citar as relações concubinárias, também por alguns sendo pretendido elevá-las à categoria de entidades familiares, em nome - sempre dela - da dignidade da pessoa humana, tendo em conta os próprios companheiros e filhos eventualmente oriundos dessa relação.

Ainda uma vez é nosso entendimento, respeitados os contrários, que vivemos numa sociedade que erigiu a monogamia ao status de "quase-princípio", através da proibição da multiplicidade de relações matrimoniais, ante o patente interesse do Estado em garantir forma estável à família, pois, nunca é demasiado dizer, toda construção depende, para manter-se íntegra, de base estável, e a melhor construção social se funda na mais sólida base familiar.

Como recordamos em outros temas, aqui também é de se mencionar que alguns povos e religiões permitem a poligamia, como os mulçumanos e os mórmons.

Acaso se aplicaria a esses o princípio da dignidade da pessoa humana, caso viessem, com suas famílias, fixar residência em meio à sociedade brasileira, com necessário reconhecimento de entidade familiar a todos? Não seria, também,

\footnotetext{
${ }^{91}$ O Projeto de Lei 1151/95 e seu substitutivo constam, na íntegra, do Anexo B, sob n. 1, desta.
} 
flagrante discriminação de ordem de raça e credo a não aceitação dos princípios inspiradores da formação de tais grupos?

Por óbvio, as respostas a todas essas indagações são negativas, por consistirem as hipóteses em franco desrespeito à função social da família brasileira.

\section{CASAl, Casais, Igualdade E Dignidade}

O tema da igualdade e da dignidade é de ser visto sob dois ângulos, interno e externo, em relação à entidade familiar.

A igualdade e a dignidade entre um casal é matéria que de há muito vem sendo, paulatinamente, introduzida na lei, no correr dos tempos surgindo regramentos que, mais e mais, vem procurando eliminar diferenças de tratamento entre homem e mulher nas mais diversas funções, inclusive as familiares.

Já tratamento igual e digno para os diferentes tipos de casais é questão que ainda encontra grande resistência, pois as uniões em que qualquer dos envolvidos não esteja legalmente apto ao casamento, mais especificamente concubinos e homossexuais, são clara e abertamente discriminadas, tanto pelo sistema legal vigente como pela maioria da sociedade, que a esses negam direitos, muitas vezes sequer reconhecendo neles vínculo passível de preservação.

É tarefa do doutrinador e do legislador, afastando-se da moral, por vezes hipócrita, que rege a vida social, encontrar resposta razoável aos problemas que vem surgindo da realidade gritada pelas novas relações entre indivíduos e que não é mais tão insignificante, em números, a ponto de poder ser placidamente ignorada, como vinha sendo até então.

Se há pessoas assumindo firme posição perante o meio social, deve, da mesma corajosa forma, o Direito posicionar-se a respeito.

Obtempera, a propósito, Antonio Junqueira de Azevedo, em dura crítica ao então Projeto do Código Civil, que "dizia Bergson que o progresso moral se verifica quando um povo, depois de viver sob determinada orientação, não quer mais voltar à anterior. O Projeto retrocede aos tempos anteriores à Constituição; será que as mudanças no Direito de Família feitas em 1988 não foram bem-aceitas 
pelo povo brasileiro ou será que são os senadores que estão alienados da nossa realidade? " 92 .

E, embora se pondo claramente contra o reconhecimento da união homossexual como família, propõe solução intermediária, por entender injustas várias situações de fato que hoje ocorrem entre pessoas dessa natureza, discorrendo que “considerando que, no livro 'Do Direito de Família' do Código Civil, há um título que não trata da família, e sim, do que Clóvis Bevilacqua chamava de institutos complementares (tutela, curatela, ausência), o Projeto nele poderia prever, num capitulo sobre relações pessoais, algumas disposições dando atendimento às pessoas que morem juntas." 93 .

No mesmo sentido, encontramos a lição de Euclides de Oliveira que, lastreado no teor da Constituição, das leis de união estável e do Código Civil, afirma que as relações homossexuais não se adéquam ao modelo de união estável, mas reconhece que são "realidade social de notória extensão", reclamando resposta do sistema jurídico para satisfação dos seus "correlatos direitos"

Lorenzetti, no tema, acrescenta ser o matrimônio uma instituição legal que aponta a organização social e, nessa função, impõe condições consideradas razoáveis pelo legislador, requisitos e impedimentos por ele citados (e aqui não reproduzidos, uma vez que o referido autor menciona aqueles atinentes ao código civil argentino, que, anote-se, são bastante similares aos do brasileiro ${ }^{95}$ ), enfeixando que "com respeito à não identidade dos sexos, foi tão óbvio que nem sequer foi considerado expressamente" ${ }^{96}$.

Ademais, o problema transborda os contornos da esfera íntima, que pertence com exclusividade ao indivíduo, onde se situa, na feliz expressão de Jean Carbonnier, o non droit $^{97}$ - lugar em que não penetram as objeções do Estado -, indo atingir outra esfera, a privada, essa de natural e necessária intervenção estatal, porque com efeitos que repercutem sobre toda a sociedade, como a concessão de direitos previdenciários e trabalhistas e auxílios à família em diversos níveis (a exemplo de

\footnotetext{
${ }^{92}$ Retrocesso... cit. (nota 3 supra), pág. 114.

${ }^{93}$ Retrocesso... cit. (nota 3 supra), pág. 114.

${ }^{94}$ União estável - Do concubinato ao casamento - Antes e depois do novo Código Civil, $6{ }^{\mathrm{a}}$ Ed., São Paulo, Método, 2003, p. 126.

${ }^{95}$ No nosso código civil os impedimentos situam-se no artigo 1521, incisos I a VII.

${ }^{96}$ Fundamentos... cit. (nota 39 supra), p. 499.

${ }^{97}$ Flexible droit, 10 a ed., Paris, L.G.D.J., 2001.
} 
subvenções para moradia, licenças por nascimento de prole, licença para aleitamento materno, bolsa-família, entre tantos outros).

Por isso, o legislador vem considerando que as relações homossexuais, embora aceitas em termos, não devem ser acolhidas no âmbito da lei, pois como as entidades familiares têm "especial proteção do Estado", subsidiadas mediante diversas políticas públicas, foi escolha da sociedade, através de seus representantes, dar tal proteção exclusivamente a casais heterossexuais, certo que " $o$ fato de $o$ legislador decidir promover alguns bens e não outros não é discriminatório. Pode inclusive proteger a união de pessoas de igual sexo mediante normas de intensidade menor" $" 98$.

Idêntico raciocínio vale para o concubinato, cuja existência, de início execrada, vem, no tempo, perdendo o caráter de crime e progredindo em direitos, mas não pode, nem deve, ser considerado forma de entidade familiar, por lhe faltar justamente, nas palavras de João Baptista Villela, a "idéia de compromisso".

Acrescenta, no tema, o nomeado jurista que tal ocorre "não só aqui, de resto, senão em todo o direito de família, que expressa difusamente a crise do amor. E a crise do amor, com já se disse, é, no fundo, a crise da responsabilidade pessoal e social, pois amar, sob quaisquer de suas formas, é essencialmente ser capaz de responder" $" 99$.

Mais, ainda: valendo-se da sábia advertência de Lorenzetti, devemos entender que "estes processos têm um ritmo histórico, que ao Direito não corresponde modificar, mas à sociedade, pois deve atingir um nível de consenso necessário para admitir normas de subsídio a condutas privadas" $" 100$.

No que concerne aos grupos formados por parentes que não os pais e filhos e outras pessoas afetivamente interdependentes (irmãos, avós, netos, tios, sobrinhos, companheiros sem interesse sexual ou patrimonial), já há simples resposta da lei, através dos institutos da guarda, tutela e curatela, conforme seja a hipótese, certo que, caso não enquadrado em qualquer das espécies legais, não se poderá considerar, em tese, o grupo como familiar, a não ser em casos peculiares e para fins

\footnotetext{
${ }^{98}$ Fundamentos... cit. (nota 39 supra), p. 500.

${ }^{99}$ Liberdade e Família, in Revista da Faculdade de Direito da UFMG, vol. III, n. 2, UFMG, Belo Horizonte, 1980, p. 17-18.

${ }^{100}$ Fundamentos... cit. (nota 39 supra), p. 500.
} 
específicos, como, aliás, já vem reconhecendo a jurisprudência ${ }^{101}$, a exemplo das exceções concedidas para as uniões homoafetivas e concubinárias.

Esse conjunto de argumentos, respaldados na mais respeitada doutrina, são os que entendemos necessários, úteis e suficientes a reafirmar nossa convicção de que as entidades familiares que hoje estão a merecer a especial proteção estatal constitucionalmente garantida são aquelas expressamente mencionadas no Texto Maior, ressalvado, entretanto, o direito a que determinados grupos, em presentes determinados requisitos, sejam conferidos direitos, não, porém, na extensão e intensidade pleiteadas.

As entidades familiares assim propriamente consideradas é que merecem, agora, ser analisadas dentro de um novo conjunto paradigmático, descabidas as sujeições paternalistas e patrimonialistas do indivíduo para que se faça sua inclusão na família, colocados os direitos-deveres do grupo familiar a serviço da humanização do vínculo ali existente.

E essa humanização deve ser alcançada através da afetividade, não como uma palavra mágica proferida sem conseqüências, mas como um norte nas atitudes das pessoas que vivenciam a relação familiar.

Surge, assim, uma nova família - formada pelo tradicional e bem conhecido grupo social de homem, mulher e filhos, contudo, revisitado em princípios e revigorado em direitos e deveres, tudo para que sejam atendidos os atuais anseios e necessidades individuais e sociais.

\subsection{CIÊNCIA MÉDICA E ORGANISMOS FAMILIARES}

O Direito de Família não costuma ser uma ciência de invenções. Antes, trabalha tendo em conta o fato e sua dimensão social, pois passa o fato a ter interesse na medida de seus efeitos na sociedade e da necessidade de seu regramento, para que

\footnotetext{
101“'Os irmãos solteiros que residem no imóvel comum constituem uma entidade familiar e por isso o apartamento onde moram goza de proteção de impenhorabilidade, prevista na Lei $n$. 8009/90, não podendo se penhorado na execução de dívida assumida por um deles" (STJ, REsp 159.851-SP, 1998).
} 
atinja uma determinada finalidade ou não venha a ferir o conjunto de interesses do grupo social no qual ocorre.

Assim, não se espera, do Direito de Família, que venha ele a criar uma nova espécie de vida, uma nova raça, um novo sexo, enfim, um novo indivíduo, até porque o indivíduo existe antes do Direito e, inclusive, é o Direito que depende da associação de mais de um indivíduo para que possa, então, surgir como ciência e instrumento de pacificação dos conflitos oriundos desse relacionamento.

O homem solitário não necessita do Direito e sobrevive perfeitamente na anomia.

Isso não ocorre, entretanto, a exemplo de outras ciências exatas, com a medicina. Nela, o campo de criação é vasto, a cada dia surgindo novas técnicas de manipulação da vida, tirando-se e colocando-se órgãos, alterando-se as estruturas celulares, utilizando-se partes de animais para reconstituição de seres humanos, dopando e estimulando o cérebro para que lembre ou esqueça, acorde ou adormeça, segundo a necessidade da eliminação da dor física e espiritual.

E mesmo o homem sozinho precisa valer-se dessa ciência para preservar sua higidez física e mental.

Assim, como seria de se esperar, o choque, o encontro dos fatos da ciência médica com o Direito de Família é sempre repleto de perplexidades.

Nessa questão, dois fatos recentes são merecedores de destaque.

O primeiro é o caso de par formado por duas mulheres lésbicas, Adriana Tito Maciel e Munira Khalil El Ourra, que vivem juntas em Carapicuiba, cidade do Estado de São Paulo, sendo que Adriana sofre de endometriose, doença que já the custou um ovário e ameaça seu útero, sendo aconselhada pelo ginecologista a ter um filho, pois a gravidez reduziria seu problema de forma significativa, tendo acolhido a proposta médica, sob incentivo de Munira ${ }^{102}$.

Entre a possibilidade de reprodução por meio natural e artificial, deram as parceiras preferência a esse último, procurando um especialista em reprodução humana assistida do Hospital Santa Joana para a inseminação artificial. Nesse passo,

\footnotetext{
${ }^{102} \mathrm{In}$ http:// revistaepoca.globo.com /Revista /Epoca /0,,ERT64032-15228-64032-3934,00.html, [23/03/2009].
} 
nova dificuldade descoberta: Adriana, em virtude da anterior extirpação de um dos ovários, já não tinha óvulos aptos ao processo de fecundação in vitro.

Munira, então, dispôs-se a fornecer os óvulos, que seriam fecundados e implantados em Adriana, o que, afinal, foi feito, com duplo sucesso, propiciando que o par de mulheres esteja aguardando gêmeos que terão características genéticas do doador anônimo (escolhido aquele que mais se aproximou das características físicas de Adriana) e de Murina, gestados por Adriana.

Mas não é só. Adriana e Munira, agora, pretendem registro das crianças que nascerão como filhos naturais de ambas, sendo patrocinadas nesse pleito pela advogada Maria Berenice Dias, desembargadora aposentada e conhecida defensora das causas das minorias, inclusive com importantes obras a respeito, algumas inclusive citadas nesta tese, questão inédita nas lides forenses, pelo que se tem notícia.

É verdade que já há alguns casos de pares homossexuais que conseguiram ser aceitos para adotar, como em Ribeirão Preto, onde João Amâncio e Edson Paulo Torres, que vivem juntos há dezessete anos, receberam quatro irmãos (dois meninos e duas meninas, entre seis e doze anos) em adoção.

Outros, além da adoção, tiveram deferida a inclusão do nome de ambos no registro da criança adotada, como no caso do par homossexual masculino Vasco Pedro da Gama e Dorival Pereira Júnior, de Catanduva, no interior do Estado de São Paulo, cujos nomes constam, agora, do assento de nascimento da menor Teodora. Note-se, entretanto, que no assento desse nascimento ficará para sempre constando tal circunstância - inclusão de nomes dos pais em virtude de adoção - ainda que em segredo oficial somente desvendável por determinação judicial de emissão de certidão de inteiro teor ${ }^{103}$.

Mas Adriana e Munira pretendem algo bem diverso, a saber, que a lei reconheça a hipótese de seres humanos poderem ter duas mães biológicas, em decorrência sendo seus nomes originariamente como genitoras, o que, em breve, será objeto de decisão judicial.

\footnotetext{
${ }^{103}$ In http://oglobo.globo.com /sp/mat /2009/01/15 /casal-homossexual-adota-4-irmaos-em-ribeiraopreto-720372646.asp, [23/03/2009].
} 
O segundo caso a ser comentado é de um casal residente nos Estados Unidos, de contornos ainda mais instigantes e difíceis.

Thomas Beatie, hoje com trinta e quatro anos, nasceu transexual, com características duplas e dúbias (genitália ambivalente e portador de sistema reprodutor feminino), foi registrado como mulher no nascimento, sob o nome de Tracy Lagondino, e assim viveu, até que efetuou, há dez anos, cirurgia para fixação de seu sexo como masculino, com mastectomia (retirada das mamas) e terapia com hormônios masculinos, preservando, todavia, seus órgãos reprodutores internos femininos -, sendo considerado, então, em procedimento judicial, legalmente homem e mudado seu nome, celebrando, após, casamento com Nancy, com quem já tinha relacionamento anterior à sobredita intervenção cirúrgica.

O casal pretendia filhos; porém, Nancy, após sofrer um aborto, em 2007, teve que submeter-se a uma histerectomia (ablação do útero), não mais podendo engravidar, anotando-se que, por casamento anterior, Nancy é mãe de duas filhas.

Aqui, então, a novidade. Thomas, ante a impossibilidade absoluta de Nancy gerar novos filhos, resolveu, em acordo com sua mulher, ele próprio gerá-los, uma vez que manteve íntegros os seus órgãos reprodutores internos (que, lembre-se são femininos).

Assim, o casal, valendo-se de material obtido em banco de esperma, iniciou série de tentativas, a primeira resultando gravidez de Thomas, de trigêmeos, todavia ectópica (com fixação do embrião fora da cavidade uterina), com perda dos embriões e de uma de suas trompas. Na segunda, contudo, houve sucesso, estando Thomas agora novamente grávido (grávida?) de uma menina, como pode ser constatado em exame de ultra-sonografia realizado ao vivo, em sensacionalista matéria, no programa de televisão da apresentadora Oprah Winfrey.

Indagações sobre quem é a "mãe" dessa criança, se tem ela duas mães, ou se foi mesmo gerada por um ser humano "masculino" - cônjuge-homem dotado de útero - com a "colaboração psicológica e afetiva" do cônjuge-mulher destituída de útero, são perguntas - é dever confessar - de quase impossível satisfatória resposta, pelo menos não à luz do Direito atual.

Vistos os dois casos (e ainda outros mencionados no corpo), parece-nos ter a ciência fugido do controle dos princípios éticos e morais comuns, para atrever- 
se na satisfação dos desejos individuais de forma eudemonista, onde procedimentos médicos transformam-se em varinha de condão que trará plena felicidade àqueles que a ela se submeterem, de forma absolutamente empírica, afastando-se, dessa maneira, dos mais altos desígnios da arte médica.

A forma como tem se sucedido os fatos do mundo lembram o enredo do célebre livro de H. G. Wells, inclusive transformado em filme, intitulado "A ilha do Dr. Moreau", onde cientista, no afã de obter integração genética entre homens e animais, se isola numa ilha para realizar seus experimentos, tema em torno do qual gravita toda uma discussão sobre religião, ética científica, behaviorismo (corrente que apresenta a Psicologia como um ramo puramente objetivo e experimental das ciências naturais, cuja finalidade seria, então, prever e controlar o comportamento de todo e qualquer indivíduo) e evolução.

Paolo Vercellone, jurista romano, mostrando enorme preocupação com os arroubos da ciência na questão da procriação artificial, aduz que "há um fato certo, isto é, na Terra não se pode mais brincar de liberdade ilimitada de cada um fazer o que quer. Não podemos mais correr certos riscos. E esta necessidade da compreensão da liberdade de agir no interesse da coletividade é, aliás, uma idéia compartilhada pelos homens conscientes. Parece, portanto, necessário que a outros e não aos próprios cientistas (ou aos industriais que estão por trás deles) seja atribuida a tarefa de proibir ou de limitar, de fazer um exame, uma avaliação do impacto ambiental mesmo, e sobretudo, para estas inovações, que não se refiram apenas à natureza externa, mas, diretamente, à humanidade "104.

É grande, aliás, a lista de espetaculares visionários (videntes?), como Michelangelo Buonarroti, Julio Verne e Isaac Asimov, além de H. G. Weels, já citado, que vaticinaram em suas obras, com espantosa precisão, o futuro além deles.

Resta saber, diante de tal quadro, se a sociedade está de acordo em fazer parte do elenco das obras legislativas e jurídicas que, nesses nossos tempos, estão sendo para ela escritas por doutrinadores, legisladores e juristas de patente visão póscontemporânea.

\footnotetext{
${ }^{104}$ As novas famílias, in Direitos de Família e do Menor - inovações e tendências, Del Rey Belo Horizonte, 1992, p. 34.
} 
As biografias de Michelangelo reportam que, após ter ele executado sua estátua Moisés, bateu violentamente com o martelo no joelho da obra e gritou: “Perché non parli?” (“- Porque não falas?”).

Desse fato devemos retirar que mesmo os gênios - que não são tantos, por vezes, perdem a noção da dimensão de sua obra, esquecem que têm limitações e que seus trabalhos, por mais que admirados sejam, não são perfeitos, mas apenas uma eterna tentativa de imitação da natureza.

Os experts do Direito estão, a cada dia, trabalhando na criação de argumentação legal que justifique todas as novas entidades como familiares e, ao final de cada tarefa, parece também gritarem à sua obra: “- porque não falas?”.

Porque, pedindo vênia para responder com a frase com a qual abrimos esse tópico, o Direito de Família não costuma ser uma ciência de invenções. 


\section{CAPÍTULO III. FILHO - UM NOVO STATUS}

\section{Introdução. A Teoria da Proteção Integral}

Toda proteção concerne diretamente a um valor protegido.

Assim, essencial ao desvendamento das questões atinentes à relação entre pais e filhos a percepção sobre qual o valor principal que se pretende proteger, qual o interesse em jogo: se é quanto a algo que toca tão só aos pais, ou se há um alcance maior, que transcende mesmo ao poder familiar.

E o véu que cobre o debate é retirado pela teoria da proteção integral, que teve início no fim do primeiro quarto do século passado, em âmbito mundial, na Declaração de Genebra, teoria essa abraçada definitivamente, em nosso Direito, pela Constituição vigente e pelo artigo $1^{\circ}$ do Estatuto da Criança e do Adolescente.

Regras de proteção especial para a criança e o adolescente vêm sendo criadas e têm evoluído através dos tempos. Em 1924, a Declaração de Genebra começou apontando "a necessidade de proporcionar à criança uma proteção especial", ao passo que a Declaração Universal dos Direitos do Homem, das Nações Unidas (Paris, 1948) menciona o "direito a cuidados e assistência especiais". Veio, então, a $1^{\text {a }}$ Declaração dos Direitos da Criança, de 1959.

Indo nesse sentido, seguiram-se os Pactos Internacionais relativos aos Direitos Civis e Políticos e aos Direitos Econômicos, Sociais e Culturais, votados pela Assembléia Geral das Nações Unidas em 16 de dezembro de 1966 e que entraram em vigor, no âmbito internacional, em 1976; a Convenção Americana sobre os Direitos Humanos (Conferência de San José da Costa Rica, 1969) que reza, em seu artigo 19, que "toda criança tem direito às medidas de proteção que na sua condição de menor requer, por parte da família, da sociedade e do Estado".

Seguem-se a Resolução 3.318 (XXIX), de 14 de dezembro de 1974, quando se fez a Declaração sobre a proteção das Mulheres e das Crianças em períodos de guerra e urgência; as Regras Mínimas das Nações Unidas para a Administração da Justiça da Infância e da Juventude - Regras de Beijing (Resolução 40/33 da Assembléia-Geral, de 29 de novembro de 1985); a Resolução 41/85, de 03 
de dezembro de 1986, com a Declaração sobre Princípios Sociais e Jurídicos aplicáveis à proteção e ao bem-estar dos menores; as Diretrizes das Nações Unidas para a Prevenção da Delinqüência Juvenil - Diretrizes de Riad (Assembléia Geral da ONU, novembro de 1990); bem como As Regras Mínimas das Nações Unidas para a Proteção dos Jovens Privados de Liberdade (Assembléia Geral da ONU, novembro de 1990), alicerces de sustentação para novas ordens no campo do Direito e da Justiça, em âmbito internacional, fundadas na nobreza e dignidade da criança.

A Convenção sobre o Direito da Criança, aprovada pela AssembléiaGeral das Nações Unidas em 20 de novembro de 1989 o foi, no Brasil, pelo Congresso Nacional brasileiro, em 14 de setembro de 1990, através do Decreto Legislativo 28, ratificado pelo Decreto 99.710 de 21 de novembro de 1990, que promulgou a Convenção, transformando-a em lei interna, cristalizando a doutrina da proteção integral devida à criança e ao adolescente. Nesse mesmo ano, entra em vigor a Lei Federal no 8.069, de 13 de julho de 1990 - o Estatuto da Criança e do Adolescente ${ }^{105}$.

Emerge desse sólido bloco de determinações ter o poder familiar a proteção da infância por vocação e o interesse do menor por finalidade, não podendo, assim, haver dúvida quanto à posição a ser adotada na solução dos conflitos gerados do poder familiar - preservar, antes de tudo, a pessoa do filho, pondo-o a salvo dos malefícios decorrentes do dissenso dos pais, caso for até excepcionando o poder familiar.

Deve o Estado, na defesa das prerrogativas da criança e do adolescente, incentivar e promover, cada vez mais, a releitura dinâmica dos direitos parentais, para que se configurem ideologicamente ao superior interesse do menor.

É fundamental direito da criança e do adolescente trilhar o caminho até a idade adulta amparado por tanto melhores quanto possíveis garantias materiais e morais, de modo a obter verdadeira e integral independência como indivíduo.

Devem restar os representantes de nosso futuro, definitivamente, livres de castigos e outros abusos físicos e psicológicos, em especial os sexuais, flagelo que ainda nos dias de hoje atinge nossa sociedade no âmago, a família, pois as estatísticas

\footnotetext{
${ }^{105}$ Sobre o rol das disposições internacionais acima, confira-se GEORGETTE NACARATO NAZO, Adoção Internacional: valor e importância das convenções internacionais vigentes no Brasil, in Revista da Faculdade de Direito da Universidade de São Paulo, vol. 92, São Paulo, 1997, p. 305.
} 
apontam que essas abomináveis práticas ocorrem, principalmente, dentro do recesso das moradias, casas de horror e sofrimento tal que nos recusamos a denominar de lares $^{106}$.

A criança e o adolescente são os novos interlocutores da família, têm voz e vez, deixaram de ser a força de trabalho interna do grupo familiar para, sob a ótica de uma saudável liberdade, serem sujeitos de direito autônomos, responsáveis e solidários.

\section{Filho: SuJeITO DE DiREITO}

Hoje não há mais dúvida sobre o predomínio da posição de dar figura de sujeito de direito à pessoa do filho, agora não mais mero objeto da discussão material, como no passado, mas indivíduo com interesses maiores - naturais, materiais, morais, sociais e afetivos -, como, aliás, a sociedade determinou, através da sua ordem constitucional, nos termos do artigo 227 da Constituição Federal ${ }^{107}$, sob inspiração das idéias gerais contidas nos mais importantes textos internacionais sobre o tema, a exemplo do artigo $3^{\circ}$ da Convenção das Nações Unidas relativa aos direitos da Criança, de 20 de novembro de 1989, onde se encontra que o interesse superior da criança deve ser de consideração primordial no debate da questão familiar.

Como sustenta Luiz Edson Fachin "os filhos não são (nem poderiam ser) objeto da autoridade parental. Em verdade, constituem um dos sujeitos da relação derivada da autoridade parental, mas não são sujeitos passivos, e sim no sentido de serem destinatários do exercício deste direito subjetivo, na modalidade de uma dupla realização de interesses do filho e dos pais." 108.

\footnotetext{
${ }^{106}$ A propósito a Revista Veja, edição 2105, de 25/03/2009, traz em reportagem de capa o triste e recorrente tema "Pedofilia - Quando o inimigo é da familia".

${ }^{107}$ “É dever da família, da sociedade e do Estado assegurar à criança e ao adolescente, com absoluta prioridade, o direito à vida, à saúde, à alimentação, à educação, ao lazer, à profissionalização, à cultura, à dignidade, ao respeito, à liberdade e à convivência familiar e comunitária, além de colocá-los a salvo de toda forma de negligência, discriminação, exploração, violência, crueldade e opressão." (artigo 227, caput, da Constituição Federal).

${ }^{108}$ Elementos críticos do Direito de Família - Curso de Direito Civil, Rio de Janeiro, Renovar, 1999, p. 223 .
} 
E o filho é sujeito de direito com interesses maiores, de obrigatória defesa pelo Estado, até em detrimento do exercício do poder familiar, caso for, como se pode ver, por exemplo, nas estipulações contidas nos artigos 1584, parágrafo único e 1586 do Código Civil, no Estatuto da Criança e do Adolescente e na doutrina moderna, onde se encontra que sendo as crianças e os adolescentes "titulares de direitos subjetivos, perfeitamente definidos no Estatuto e, em conseqüência da clara definição da existência de interesses metaindividuais de que são titulares, passou a existir, com muito mais força, a possibilidade de se exigir o respeito a estes direitos, por quem tenha legítimo interesse e, também, pelo Ministério Público, perante o Judiciário." ${ }^{109}$.

Do teor do preâmbulo da Convenção sobre as relações pessoais concernentes à criança e ao adolescente, de 15 de maio de 2003, ocorrida em Strasbourg, França, vê-se menção ao reconhecimento, pelos Estados-membros, de que, conforme prevêem os diferentes instrumentos jurídicos internacionais do Conselho da Europa, o interesse superior do menor deve ter uma consideração prioritária, declarando-se os Estados-membros conscientes da circunstância de não somente os pais, mas também os filhos, serem titulares de direitos e da necessidade de se adotar novas disposições com finalidade de preservar as relações pessoais entre a criança e seus pais e outras pessoas que com ela tenham vínculo de família, tendo em conta o direito do filho de, separadamente de seus dois pais ou de um deles, exercitar regularmente as relações pessoais e o contato direto com seus dois pais, exceto se tal contrariar o interesse superior dela, criança.

O gozo de todos os direitos fundamentais inerentes à pessoa humana é garantido, de forma irrestrita, à criança e ao adolescente, na forma do artigo $3^{\circ}$ do Estatuto da Criança e do Adolescente, presentes no texto do referido estatuto, ainda, os princípios da universalidade (por atingir todas as crianças e todos os adolescentes), do devido processo legal, da prioridade absoluta (conforme expresso no artigo $4^{\circ}$, do Estatuto da Criança e do Adolescente e artigo 227 da Constituição Federal), do atendimento compartilhado (ou responsabilidade concorrente, na forma dos supracitados artigos ${ }^{110}$ ), da municipalização do atendimento e da participação popular (encontrados, esses últimos, no artigo 88 , incisos I e II, do Estatuto da

\footnotetext{
${ }^{109}$ GIOVANE SERRA AZUL GUIMARÃES, Adoção, Tutela e Guarda, São Paulo, Juarez de Oliveira, 2000, p. 4.

${ }^{110}$ Artigo 227 cit. (nota 107 supra)
} 
Criança e do Adolescente - quanto à política de atendimento da criança e do adolescente), todos tendentes a garantir à criança e ao adolescente, de forma efetiva, sua condição de especiais sujeitos de direito.

O reconhecimento do filho gera, como dito, o surgimento do poder familiar e a criança, "como conseqüencia, torna-se sujeito de vários direitos, que podem ser exigidos dos pais." "111.

Não se deve, contudo, ampliar em demasia os direitos tocantes aos filhos, esquecendo-se, em contrapartida, da existência de deveres desses em relação à pessoa dos pais, pois, quanto ao poder familiar, como lembra Roberto João Elias, “o fato de seu exercício ter em vista o interesse dos menores não afasta...o direito dos progenitores." 112 .

Não se pode perder de vista que, se a noção de supervisão paterna deu lugar à de proteção integral da prole, os pais permanecem podendo regular as relações do menor com o exterior, escolher os lugares que devem freqüentar e as amizades que podem cultivar, controlar seus meios de comunicação (postal, telefônica, eletrônica), controlar seu acesso a artes e espetáculos (leitura, exposições, cinema, teatro), eleger os tratamentos médicos mais adequados, decidir sobre sua educação, na acepção mais larga do termo, ministrando-lhes eles próprios instrução, bem como a propiciando através de institutos do gênero - nesse caso escolhendo entre a rede pública ou privada e entre os diversos tipos de ensino - incluídos elementos de ordem moral, religiosa, lingüística e étnica, tudo no exercício dos poderes expressos no artigo 1634 do Código Civil.

Podem, ainda, a título de educação, valer-se do direito de correção, afastados, evidentemente, reprimendas físicas e verbais imoderadas, maus-tratos e tratamentos humilhantes ou degradantes de qualquer espécie, com se extrai do teor dos artigos 1637 e 1638 do Código Civil.

São os genitores - ainda aqui também embasados no poder a eles conferido pelo artigo 1634 do Código Civil - que escolhem a residência dos filhos, que os autorizam a viajar, que podem reivindicá-los, inclusive com o auxílio da força

\footnotetext{
${ }^{111}$ Cf. ROBERTO JOÃo ELIAS, Pátrio Poder - Guarda dos Filhos e Direito de Visita, São Paulo, Saraiva, 1999, p. 2.

${ }^{112}$ Pátrio Poder cit. (nota 111 supra) p. 3.
} 
do Estado, se necessário, de quem os detenha ilegalmente, ou reconduzi-los ao lar, em caso de fuga.

\section{O PODER FAMILIAR}

Examinadas as mudanças ocorridas no conceito de família, ocupar-nosemos das transformações, não menos importantes e de todo correlatas, ocorridas no agora chamado "poder familiar", substituto do "pátrio poder".

Partindo do poder de vida e morte ostentado pelo paterfamilias, do Direito Romano, passando pelo advento do cristianismo, que o abranda, e por várias legislações, pelo mundo todo, que foram transformando seu antigo caráter, egoístico e centrado na pessoa do chefe de família, em um novo caráter, assistencial e protetivo do menor, chegamos à evolução final, em que o "poder" transmutou-se em "dever"113.

Pontes de Miranda, já em 1947, no seu "Tratado de Direito Privado", ensinava que "o pátrio poder moderno é o conjunto de direitos concedidos ao pai ou à própria mãe, a fim de que, graças a eles, possa melhor desempenhar a sua missão de guardar, defender e educar os filhos, formando-os e robustecendo-os para a sociedade e a vida." "114, apontando, com esse ponto de vista, caminhos para a transformação da visão clássica do tema, em meio ao rigor do Código Civil de 1916.

Esse enfoque vem, na atualidade, renovado e reforçado pela novel Carta Constitucional, no seu artigo 227, caput, e pelo Estatuto da Criança e do Adolescente (Lei 8069/90), no seu artigo $4^{\circ}$, ambos destacando ser dever da família, da comunidade, da sociedade em geral e do poder público assegurar à criança e ao adolescente, com absoluta prioridade, a efetivação dos direitos referentes à vida, à saúde, à alimentação, à educação, ao esporte, ao lazer, à profissionalização, à cultura, à dignidade, à liberdade e à convivência familiar e comunitária.

O poder familiar, dessa forma, mostra evolução e ajustamento congruente com a nova visão da família, não cabendo no renovado esquema familiar a figura do

\footnotetext{
${ }^{113}$ Cf. F. LAURENT, Principes du Droit Civil français, vol. 4, $3^{\text {a }}$ ed., Bruxelas, Bruylant-Christophe \& Cia., 1893, p. 350.

${ }^{114}$ Vol. 9, $3^{\mathrm{a}}$ ed., Rio de Janeiro, Max Limonad, 1947, p. 71.
} 
paterfamílias, pois o grupo familiar não tem mais um "chefe", com uma "auxiliar", comandando a prole, mas pais e filhos interagindo através de um conjunto de direitos e deveres mútuos, dentro dos princípios fundamentais constitucionalmente estabelecidos, como se verá.

\subsection{HISTÓRICO}

Havendo já se destacado a origem do poder familiar, então chamado pátrio poder, no Direito Natural, é certo se dizer nascido ele no primórdio da civilização, com a formação da primeira família e as ações praticadas pelos pais para que o primogênito vingasse e assim outros e outros, na infindável sucessão de atos de preservação da vida.

Contudo, é com o Direito Romano (vigente do século VIII a. C. até o século VI d. C.) que o instituto toma corpo e assim, a doutrina, de modo geral, o estabelece como marco inicial de pesquisa, até porque as raízes de tal direito tornaram-se o sustentáculo de várias legislações pelo mundo, alimentando até hoje a árvore de inúmeros sistemas jurídicos.

A patria potestas, instituto que dava poder absoluto ao paterfamilias sobre as pessoas e bens que compunham o grupo familiar, era ilimitado e duradouro. Exclusivo do varão, dava direito de vida e morte sobre a prole (ius vitae et necis), podendo vendê-la ou abandoná-la.

A respeito de sua extensão encontramos que "para ter a completa capacidade jurídica de gozo, era preciso que o sujeito, além de ser livre e cidadão romano, fosse também independente do pátrio poder. A organização familiar romana distinguia entre pessoas sui iuris (paterfamilias), independentes do pátrio poder, e pessoas alieni iuris, sujeitas ao poder de um paterfamilias. A independência do pátrio poder não tinha relação com a idade. Um recém-nascido, não tendo ascendente masculino, era independente do pátrio poder, ao passo que um cidadão 
de 70 anos, com o pai ainda vivo, era alieni iuris, isto é, sujeito, na qualidade de filiusfamilias, ao poder de seu pai." ${ }^{\prime 15}$.

Era, assim, vitalício, ao contrário do que ocorre atualmente, quando o poder familiar se encerra no momento da maioridade do filho.

Foi com o advento da Lei das XII Tábuas (século V a. C.) que passou tal poder desmedido a sofrer restrições, até chegarmos a Justiniano (século VI d. C.), quando o poder do pai encontrou limite na possibilidade de correção dos filhos.

Em outra vertente, temos os costumes germânicos a informar as diretrizes do relacionamento entre pais e filhos, costumes esses tendentes a cuidar com maior atenção e relevo dos interesses dos filhos que dos direitos do pai sobre eles, podendose apontá-los como inspiradores da teoria da proteção integral ${ }^{116}$ agora abraçada em nossa legislação.

E, a partir do período medievo, a estrutura da família, pelo mundo, passou a balizar-se por essas duas correntes: de um lado a romana - nos países onde imperava o direito escrito; de outro a germânica, onde prevalecia o direito costumeiro.

A doutrina cristã, de grande influência na modificação do pensamento desde então, aproximou e fundiu as características desses dois sistemas, apontando o direito-dever de amparo material e moral, embora sempre sofrendo resistências dos setores conservadores, como na França, onde a tradição romana, abraçada no Sul, foi temperada pela germânica, prestigiada no Norte, a respeito do que Aubry e Rau, no seu Cours de Droit Civil Français, fizeram constar não ter o legislador dado ao pátrio poder a extensão e energia que reclamavam a ordem pública e os bons costumes $^{117}$.

No Direito brasileiro, o pátrio poder foi introduzido por lei de $20 \mathrm{de}$ outubro de 1823, cópia das Ordenações do Reino, por sua vez reprodução do Direito Romano, assim permanecendo no Código Civil de 1916. Com o passar dos anos, no entanto, grandes modificações se processaram, no rumo da igualdade entre pais,

\footnotetext{
${ }^{115}$ THOMAS MARKY, Curso elementar de Direito Romano, $2^{\mathrm{a}}$ ed., São Paulo, Resenha Tributária, 1974, p. 54-55.

${ }^{116}$ Tema abordado no tópico 1 deste capítulo.

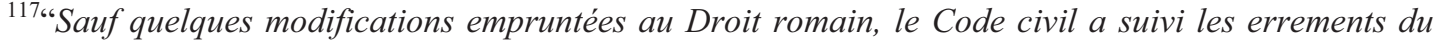
Droit coutumier. Toutefois, il n'a pas restitué à la puissance paternelle l'étendue et l'énergie que réclamaient l'ordre public et les bonnes moeurs.". t. IX, Paris, Marchal et Godde, 1917, p. 107.
} 
entre filhos e entre todos esses, podendo ser citados o Estatuto da Mulher Casada, a Lei do Divórcio, a Constituição Federal, o Estatuto da Criança e do Adolescente, o Código Civil e a Lei da Guarda Compartilhada como importantes acontecimentos legais na matéria.

\subsection{EVOLUÇÃO TERMINOLÓGICA}

Nascida a patria potestas como poder de dominação, absoluto, discricionário, foi a força contida na expressão pátrio poder, pelos tempos, amoldando-se mais ao sentido de poder de proteção, até desaguar no formato hodierno por nós conhecido.

Hoje, o pátrio poder, na forma construída pela gens romana não mais subsiste. Daí surgirem correntes pretendendo substituir a milenar expressão por outra, que talvez melhor representasse as modernas tendências do instituto.

Entre elas podemos citar, além da utilizada no código - poder familiar -, outras como poder parental, autoridade parental, responsabilidade parental, poder de proteção, função parental, poderes e deveres parentais, pátrio dever, dentre outras aventadas pelos mais diversos autores ${ }^{118}$.

E, na legislação pelo mundo, vemos o instituto assim chamado: na Itália, "poder dos genitores"119; na Alemanha, "cuidado parental"120; na Espanha, "das relações paterno-filiais" ${ }^{21}$; no Chile, "direitos e obrigações entre pais e filhos" "122; na França $^{123}$, na Suíça ${ }^{124}$ e nos Estados Unidos ${ }^{125}$, “autoridade parental”; na Bolívia, "autoridade dos pais""126; na Rússia, "direitos e a responsabilidade de pais e

\footnotetext{
${ }^{118}$ Com vasta lista a respeito: JOSÉ VIRGÍLIO CASTELO BRANCO ROCHA, O pátrio poder, $2^{\mathrm{a}}$ ed., São Paulo, LEUD, 1978, p. 35; WALDYR GRISARD FILHO, Guarda Compartilhada: um novo modelo de responsabilidade parental, São Paulo, RT, 2000, p. 31-33, entre outros.

${ }^{119}$ Código Civil italiano, Livro Primeiro, Título IX - Della potestá dei genitori.

${ }^{120}$ Código Civil alemão, Livro 4, Seção 2, Título 5 - Elterliche Sorge.

${ }^{121}$ Código Civil espanhol, Livro I, Título VII - De las relaciones paterno-filiales.

${ }^{122}$ Código Civil chileno, Livro Primeiro, Título IX - De los derechos y obligaciones entre los padres y los hijos.

${ }^{123}$ Código Civil francês, Livro Primeiro, Título IX - De l' autorité parentale.

${ }^{124}$ Código Civil suiço, Livro Segundo, Parte Segunda, Título Oitavo, Capítulo Terceiro - Dell'autorità parentale.

${ }_{125}^{12}$ Código da Georgia, 49-5-281 (3) - parental authority.

${ }^{126}$ Código de Família boliviano, Livro Terceiro, Título I - De la autoridad de los padres.
} 
filhos"127; em Portugal, "poder paternal"128; no Conselho da Europa, "responsabilidade parental"129.

O que primeiro se extrai dessas inúmeras formas de denominação é o fato da maioria delas pretender eliminar a palavra "poder" da conceituação, pois essa traria a noção de império, posse, sujeição, submissão, sentido que se quer ver afastado do instituto, conquanto alguns digam que tal palavra não traz, em si, a conotação negativa que lhe atribuem - ao contrário, retrata com acerto a parcela de controle que os pais devem ter sobre a pessoa dos filhos e o respeito e obediência por esses devidos aos genitores.

Em segundo lugar, vê-se clara a intenção de firmar-se a mãe em condições de igualdade com o pai, assim, alijando-se vocábulos que dessem a noção de que o instituto seria destinado a ser regido pelos varões da família.

Claude Colombet, explicando a modificação de expressões na França, esclarece que a autoridade parental substituiu, em 1970, o poder paternal: mudança de palavras e mudança de espírito; a fórmula que evoca os direitos e deveres dos pais em relação a seus filhos merecia ser alterada: a idéia de poder evocava a de dominação, que não convém mais às nossas sociedades atuais; a atribuição paternal excluía a mãe, o que não era conforme com a noção de igualdade figurante entre os nossos princípios gerais do Direito; a evolução mesmo da concepção do casamento com derivação da idéia de proteção para a de associação, resultante do número cada vez mais elevado de mulheres que têm uma atividade profissional - devia necessariamente provocar uma modificação nos relacionamentos parentais: a idéia de chefe da família não se justificava mais; um novo grande princípio devia ser escrito $^{130}$.

\footnotetext{
${ }^{127}$ Código de Familia russo, Divisão IV - Ïđàâà è îáy̆çàilîñòè điäèòåe̊åé è äåòåé.

${ }^{128}$ Código Civil português, Livro IV, Título III, Seção II.- Poder paternal

${ }^{129}$ Convenção sobre as relações pessoais concernentes aos menores, Strasbourg, 15 de maio de 2003, Preâmbulo - responsabilité parentale.

${ }^{130}$ "L'autorité parentale a remplacé, en 1970, la puissance paternelle: changement de mots et changement d'esprit; la formule qui évoque les droits et les devoirs des parents à l'egard de leurs enfants méritait d'être modifiée: l'idée de puissance évoquait la domination, qui ne convient plus dans nos sociétés actuelles; l'attribution paternelle excluait la mère, ce qui n'etait pas conforme à la notion d'égalite figurant parmi nos príncipes géneraux du droit; l'évolution même de la conception du mariage - avec un glissement de l'idée de protection vers celle d'association, résultant $d u$ nombre de plus en plus élevé de femmes ayant une activité prefessionnelle - devait nécessairement entraîner une modification dans les rapports parentaux: l'idée de chef de la famille ne se justifiait plus; un nouveau grand principe devait être écrit.". La famille - Collection Droit Fondamental Droit Civil, $5^{\text {a }}$ ed., Paris, PUF, 1997, p. 255 - tradução do doutorando.
} 
Porém, as inovações também são alvo de críticas. Quando se fala em “autoridade parental", por exemplo, objeta-se que o termo "parental" é por demais aberto, dando margem a elastérios como querer incluir os demais ascendentes na relação, ou mesmo os descendentes mais velhos.

Aliás, essa a posição do supracitado doutrinador, nos termos da lei francesa, apontando que enquanto os textos anteriores a 1970 continuavam silentes sobre o conteúdo exato da autoridade parental no que toca à pessoa da criança, a lei esforçou-se em precisar os direitos e deveres dos pais, bem como os direitos excepcionais que podem ser reconhecidos a terceiros - avós ou outras pessoas ${ }^{131}$.

Ao termo "paternal", do Código Civil português, também se faz restrições, mas é de se dizer que "paternal", no sentido lato, derivado de patres, significa o colegiado de pai e mãe.

Por fim, o termo utilizado pelo atual Código Civil brasileiro também mereceu objeções, uma vez que julgado inadequado denominar-se o instituto de “poder familiar", na medida em que, além de mantida a designação "poder" cabendo nesse ponto a repetição das críticas acima elencadas, a adjetivação "familiar" seria incabível, posto que as prerrogativas do referido "poder" diriam respeito a pais e filhos e não à família como um todo.

Silvio Rodrigues indica estar o legislador, no Código Civil, "pecando gravemente ao mais se preocupar em retirar da expressão a palavra 'pátrio', por relacioná-la impropriamente ao pai (quando recentemente já lhe foi atribuido aos pais e não exclusivamente ao genitor), do que cuidar para incluir na identificação o seu real conteúdo, que, antes de poder, como visto, representa uma obrigação dos pais, e não da família, como sugere o nome proposto." ${ }^{132}$.

Vale citar que há vários países onde permanece vivo o uso uniforme da expressão "pátrio poder", como na Argentina ${ }^{133}$, na Venezuela ${ }^{134}$, no Uruguai ${ }^{135}$ e em

\footnotetext{
131، “alors que les textes antérieurs à 1970 restaient muets sur le contenu exact de l'autorité parentale en ce qui a trait à la personne de l'enfant, la loi s'est efforcée de préciser les droits et devoirs des parents, ainsi que les droits exceptionnels qui peuvent être reconnus à des tiers-grands-parents ou autres personnes.". La famille cit. (nota 133 supra) p. 257 - tradução do doutorando.

${ }^{132}$ Direito Civil, vol. 6, $27^{\mathrm{a}}$ ed., São Paulo, Saraiva, 2002, p. 397.

${ }^{133}$ Código Civil argentino, Livro Primeiro, Título 3 - De la patria potestad.

${ }^{134}$ Código Civil venezuelano, Livro Primeiro, Título VII - De la patria potestad.

${ }^{135}$ Código Civil uruguaio, Livro Primeiro, Título VIII - De la patria potestad.
} 
Porto Rico ${ }^{136}$, além do que em muitos outros, embora incluídas novas formas de menção ao instituto, constata-se a concomitante utilização da tradicional, não só em legislações esparsas, mas também nos próprios textos principais sobre o assunto, como, por exemplo, nos casos do artigo 243 do Código Civil chileno e do artigo 154 do Código Civil espanhol, países antes mencionados no rol daqueles em que se fez introduzir novas denominações ao poder-dever aqui objeto de análise.

Melhor, talvez, tivesse sido mantido o nome clássico - "pátrio poder" -, já assimilado pela doutrina, jurisprudência e todos os operadores do Direito, além do que constante de inúmeros outros textos legais ainda vigentes, até porque a extensão, alcance, direitos e deveres compreendidos no instituto em nada restariam abalados por tal manutenção; alternativamente, eleger-se a expressão franco-americana "autoridade parental" - ante ser patente fonte de inspiração para as novas idéias no tema - como representativa do poder-dever presente no instituto e da indicação de seus respectivos titulares - os pais $-{ }^{137}$.

Curioso anotar que, no artigo 932 do Código Civil, o legislador fez constar a expressão "sob sua autoridade", quanto ao poder dos pais em relação aos filhos, em substituição à anterior "sob seu poder", contida no artigo 1521 do Código Civil de 1916, do qual é cópia, à exceção do detalhe apontado, o que não se justifica, ante a adoção da rubrica "poder familiar", no Capítulo V, do Subtítulo II, do Título I, do Livro IV, do Código Civil, além do que indica acolhimento, ainda que parcial, da tese sustentada por parcela dos doutrinadores quanto à melhor adequação da designação "autoridade parental", como acima mencionado, já que a "autoridade" ali constante é a autoridade dos pais, ou seja, "autoridade parental".

\footnotetext{
${ }^{136}$ Código Civil porto-riquenho, 31 L.P. R.A. sec. 591 - Patria potestad.

${ }^{137}$ Essa a posição externada por SILMARA JUNY CHINELATO, em comentário ao artigo 1630, do Código Civil, onde esclarece que "O projeto de Código Civil com o texto aprovado pela Câmara dos Deputados consignava, ainda, no art. 1658, a expressão 'pátrio poder', que foi alterada para 'poder familiar' pela Emenda n. 279 do Senado Federal. Em que pese a ponderação do legislador no sentido de ser exercido 'em conjunto por ambos os cônjuges em razão do casal e da prole', não me parece tenha sido uma substituição feliz nem própria. Poder familiar sugere ampliação de titulares detentores de um 'poder' bastante esvaziado de conteúdo. A evolução do instituto do pátrio poder, mais centrado em deveres, bem demonstra a impropriedade da expressão 'poder'. $O$ adjetivo 'familiar' também não me parece oportuno. O poder-dever, ou, mais propriamente, a autoridade, é dos pais, por isso parental, e não 'familiar'. Família indica conceito lato que ultrapassa a pessoa dos pais. Por tais razões considero duplamente imprópria a expressão 'poder familiar'. Não é poder e não é familiar. Melhor seria a expressão 'autoridade parental', que indica a tônica interativa e de diálogo entre poderes e deveres e limita os titulares verdadeiros a quem a autoridade compete: os pais, e não a família.". In Comentários ao Código Civil-artigos 1591 a 1710, vol. 18, São Paulo, Saraiva, 2004, p. 219.
} 


\subsection{CONCEITO}

Previsto no Capítulo V, do Subtítulo II, do Título I, do Livro IV, do Código Civil (artigos 1630 a 1638), o agora legalmente denominado poder familiar, chamado pelas leis anteriores pátrio-poder (vide Capítulo VI, do Título V, do Livro I, do Código Civil de 1916, artigos 379 a 395; e artigo 21, da Lei 8069/90 - Estatuto da Criança e do Adolescente), vem sendo objeto de incessantes estudos.

Foram deslocadas as questões "Do usufruto e da administração dos bens de filhos menores" para o Subtítulo II, do Título II, que trata de direito patrimonial (artigos 1689 a 1693 do Código Civil), a indicar a preocupação do legislador de separar, do trato das questões atinentes aos interesses pessoais do menor, aquelas outras questões concernentes aos seus interesses patrimoniais.

Bem antes da atual conformação constitucional dada ao assunto, renomados juristas, da estirpe de Lafayette Rodrigues Pereira e Clóvis Beviláqua, destacavam o exclusivo poder conferido pela lei anterior ao pai, sobre a pessoa e os bens do filho, poder esse já apontado, contudo, como "de uma amplitude que se nos afigura hoje odiosa"138, até porque "esta nobre missão a natureza confiou-a ao pai e à mãe... a instituição do pátrio-poder, tal como se acha constituída pelo nosso Direito, é um invento absurdo, imaginado antes em utilidade e vantagem do pai do que em beneficio do filho." 139 .

No entanto, quase um século teve que se passar, desde as contundentes críticas de Lafayette Rodrigues Pereira à feição dada pela lei ao instituto, para que, finalmente, a lei civil viesse a contemplá-lo como em verdade pedia o seu espírito - a soma equilibrada de direitos e deveres, faculdades e necessidades, interdependentes, que deve visar sempre como resultado o crescimento completo dos seres humanos que, através deles, interajam.

\footnotetext{
${ }^{138}$ CLÓvis BEVILÁQUA, Código Civil dos Estados Unidos do Brasil comentado, vol. 2, 12 a ed., Rio de Janeiro, F. Alves, 1960, p. 279.

${ }^{139}$ LAFAYETTE RODRIGUES PEREIRA, Direitos de Família, Rio de Janeiro, Fonseca Filho, 1910, p. 233-234.
} 
O poder familiar é um direito de família puro, ou seja, traz como características a irrenunciabilidade, a imprescritibilidade, o direito de proteção, a temporariedade e a indisponibilidade ${ }^{140}$.

Sobre o porquê da indisponibilidade em matéria de Direito de Família, Carlos Alberto Dabus Maluf ensina que a transação tem por objeto somente direitos patrimoniais de caráter privado - regra que encontramos no art. 841 do Código Civil, "daí a ilicitude e a inadmissibilidade de transação atinente a assuntos relativos...à legitimidade ou dissolução do casamento; à guarda dos filhos; ao pátrio poder...Alguns dos direitos contidos no direito de família são indisponíveis, seja porque a lei veda a disponibilidade deles, seja porque, mesmo a permitindo em certos casos, impõe-lhe limites. Interessam não apenas à pessoa como tal, mas à família, à sociedade e ao Estado."141.

Hodiernamente, encontramos diversas definições do poder familiar, tais como "o complexo de direitos e deveres concernentes ao pai e a mãe, fundado no Direito Natural, confirmado pelo Direito Positivo e direcionado ao interesse da família e do filho menor não emancipado, que incide sobre a pessoa e patrimônio deste filho e serve como meio para o manter, proteger e educar" ${ }^{142}$; "o conjunto de faculdades encomendadas aos pais, como instituição protetora da menoridade, com o fim de lograr o pleno desenvolvimento e a formação integral dos filhos, seja físico, mental, moral, espiritual e social ${ }^{143}$. Para alcançar tal desiderato impõe-se ainda aos pais satisfazerem outras necessidades dos filhos, notadamente de indole afetiva, pois o conjunto de condutas pautado no artigo 384 do Código Civil ${ }^{144}$, o é em caráter mínimo, sem excluir outros que evidenciem aquela finalidade."145; "o conjunto de direitos e deveres atribuídos aos pais, em relação à pessoa e aos bens

\footnotetext{
${ }^{140}$ Pátrio Poder cit. (nota 111 supra), p. 107.

${ }^{141}$ A transação no Direito Civil e no Processo Civil, $2^{\mathrm{a}}$ ed., São Paulo, Saraiva, 1999, p. 65-66.

${ }^{142}$ JOSÉ ANTÔNIO DE PAULA SANTOS NETO, Do pátrio poder, São Paulo, RT, 1994, p. 55.

${ }^{143} \mathrm{Na}$ forma do disposto no artigo $3^{\circ}$, da Lei 8069/90, Estatuto da Criança e do Adolescente, que assim reza: "A criança e o adolescente gozam de todos os direitos fundamentais inerentes à pessoa humana, sem prejuizo da proteção integral de que trata esta lei, assegurando-se-lhes, por lei ou por outros meios, todas as oportunidades e facilidades, a fim de lhes facultar o desenvolvimento físico, mental, moral, espiritual e social, em condições de liberdade e dignidade.".

${ }^{144}$ Código Civil de 1916, atual artigo 1634 do Novo Código Civil.

${ }^{145}$ Guarda Compartilhada cit. (nota 118 supra) p. 27.
} 
dos filhos não emancipados, tendo em vista a proteção destes...É o munus público, imposto pelo Estado, aos pais, a fim de que zelem pelo futuro de seus filhos."146.

Tais posicionamentos doutrinários e legais atendem, aliás, ao disposto nos artigos 5 $5^{\circ}$, I, 226 e 227 da Constituição Federal, aos quais, diga-se, adequou-se o então Projeto do atual Código Civil, que mantinha, até pouco antes de sua aprovação, expressões como "pátrio-poder”, “filhos legítimos, legitimados, legalmente reconhecidos e adotivos".

Esses autores contemporâneos, de escolas e formação algo diferentes, tiveram seus conceitos escolhidos para análise porque, conquanto tenham pontos comuns, cada qual traz elementos julgados essenciais, não contidos nos demais.

Assim é que, no tradicional livro de Sílvio Rodrigues, vemos acentuada a característica de intervenção do Estado na relação de família; enquanto Waldyr Grisard Filho, em sua obra, destaca a "índole afetiva" que deve permear essa mesma relação; encontrando na de José Antonio de Paula Santos Neto menção ao Direito Natural ou, como lembra Rui Geraldo Camargo Viana, os "fundamentos metajurídicos", que também integram o Direito de Família, "a saber: a moral, a religião, os costumes, tudo a formar a indivisível trama que compõe o 'non-droit', segundo a dicção de Carbonnier." 147.

Disso resulta, usando as palavras de Waldyr Grisard Filho sobre o assunto, um "cipoal doutrinário" $" 148$, onde os operadores do Direito lutam por encontrar uma unidade de pensamento e ação, que preserve o equilíbrio e coexistência das forças da natureza, da lei e do sentimento, presentes de forma indiscutível no tema, assente, a esta altura, que o novo cerne da questão é o filho menor e não seus pais.

Sintetizando e dando contribuição aos pensamentos acima expostos, definimos o poder familiar como um conjunto de direitos e deveres ligados entre si de forma indissolúvel, existentes entre pais e filhos, tendentes a manter a organização

\footnotetext{
${ }^{146}$ Direito Civil cit. (nota 132 supra) p. 349.

${ }^{147}$ A familia cit. (nota 8 supra) p. 50.

${ }^{148}$ Guarda Compartilhada cit. (nota 118 supra) p. 27.
} 
natural, material, moral, social e afetiva da família, com ênfase na proteção integral da prole e mediante o auxílio solidário da sociedade e do Estado ${ }^{149}$.

\section{FiLhos, Igualdade E Dignidade}

Filiatio, termo do latim que sempre representou o enlace de pais e filhos, o laço de parentesco, de dependência, entre eles existente, assumiu, nos tempos atuais, conteúdo mais amplo e complexo, ante as inúmeras possibilidades de fíliação abarcadas pelo conceito.

À filiação biológica, primeira de todas, vieram juntar-se uma infinidade de outras, chamadas não biológicas, de início restringidas em seu alcance, depois estendidas a tal nível que, hodiernamente, já não há mais espaço para distinção entre filhos biológicos e não biológicos, garantida a igualdade de todos, indistintamente, pela Carta Maior ${ }^{150}$, de resto repetida, em reforço, no código civil ${ }^{151}$.

A par dessa realidade, continuam existindo problemas relacionados à origem do indivíduo que, como pessoa humana repleta de marcas indeléveis, desde as mais simples constatáveis - como as características físicas, até aquelas presentes no seu DNA, tem o direito e mesmo a necessidade de saber a identidade de seus geradores, pois dessas decorre uma série de fatores que irão influir e compor a sua própria, nos aspectos pessoal e social.

Assim é que a fixação da cidadania, a escolha de um determinado tratamento médico, a possibilidade de uma união entre duas pessoas, entre tantas hipóteses imagináveis, são influenciadas pelo conhecimento que o indivíduo tem de si mesmo.

Para a criança, especialmente, a plena identificação dos seus pais, dos responsáveis pelo exercício do poder familiar e da concreção dos direitos-deveres ali contidos, é de suma importância, conquanto cada vez mais distantes estejam os critérios puramente biológicos dos jurídicos, na fixação da filiação.

\footnotetext{
${ }^{149}$ Conforme o contido na dissertação de mestrado do doutorando, "Guarda compartilhada - evolução do conceito dentro do novo sistema jurídico brasileiro", com a qual obteve o grau de mestre em Direito, na área de Direito Civil, em 2005, na FADUSP.

${ }^{150} \mathrm{Na}$ forma do artigo $227, \S 6^{\circ}$, da Constituição Federal.

${ }^{151}$ Conforme regra do artigo 1596, do Código Civil.
} 
Sendo livre a escolha de ter filhos, bem como dos métodos utilizados na consecução (biológico ou não biológico), uma vez que estabelecido no artigo 226, § $7^{\circ}$, da Constituição, ser o planejamento familiar livre decisão do casal, passa, contudo, a ser dever do responsável (ou responsáveis) pela escolha positiva dispensar igual tratamento de qualidade a tantos filhos quantos venha (ou venham) a ter, em conformidade com o artigo 227, caput, da Carta Constitucional.

Todos os princípios elencados no capítulo de abertura desta tese são plenamente aplicáveis na garantia da concreção dos direitos-deveres decorrentes da filiação.

A igualdade entre filhos, a primeira sempre mencionada, tem tal status em virtude de ter vencido as resistências de malsinadas expressões até duas décadas utilizadas para adjetivar "espécies" de filhos, entre elas, "legítimos", "naturais", "legitimados", "reconhecidos", “adotivos", "ilegítimos" (nas diversas variações, como "espúrios", "incestuosos", "bastardos", "adulterinos”, “de fora”, "sacrílegos", também chamados "de coito danado" "152).

Os princípios da dignidade da pessoa humana, da liberdade, da solidariedade, da afetividade, da convivência familiar, do melhor interessa da criança e do adolescente e da segurança jurídica, vem em socorro daqueles que desejam satisfação dos mais diversos interesses, como os ligados à identidade, à personalidade, à saúde e à cidadania, entre outros.

A filiação socioafetiva, patenteada na adoção legal, na chamada “adoção à brasileira” e na concepção por inseminação artificial heteróloga, não mais é objeto de contestação social, a par dos inúmeros problemas jurídicos que a circundam (como é o caso de ações onde se discute o efeito de arrependimento posterior ou alegado vício legal pelo pai, assim como o repúdio do filho adotado à(s) pessoa(s) do(s) adotante(s), mesmo antes de completar a maioridade), e o reconhecimento do vínculo filial através da figura da posse do estado de filho vem ganhando cada vez mais adeptos.

\footnotetext{
${ }^{152}$ AURÉLIO BUARQUE DE HOLANDA FERREIRA, Dicionário Aurélio, versão eletrônica 5.0, São Paulo, Positivo, 2009.
} 
Para Maria Berenice Dias "os vínculos de filiação não podem ser buscados na realidade biológica, e a definição da paternidade está condicionada à identificação da posse do estado de filho"153.

João Batista Villela afirma, na questão, que "a verdadeira paternidade não é um fato da biologia, mas um fato da cultura. Está antes no devotamento e no serviço do que na procedência do sêmen"154.

O tema da guarda de filhos vem sendo tratado preponderantemente sob a ótica do melhor interesse da criança, relegados a segundo plano os interesses e direitos dos pais, se necessários sacrificados em função da obtenção do mais favorável resultado aos filhos.

O Superior Tribunal de Justiça tem, com constância, interpretado a lei em favor da proteção ao vínculo filial, como nos casos em que se reconheceu válida a pretensão desses, substituindo o pai, em investigar a filiação deste, junto ao avô (relação avoenga), dirigindo a lide contra os referidos herdeiros, especialmente em face da nova Constituição (STJ, REsp 269 - RS, Rel. Min. Waldemar Zveiter, DJU, 7 de junho de 1990; REsp 603883 - RS, Rel. Min. Carlos Alberto Menezes Direito, DJU, 20 de junho de 2005) e de ser considerada possível adoção póstuma ainda que não haja procedimento iniciado pelo falecido, desde que demonstrada a vontade de adotar e laços de afetividade em vida (STJ, REsp 823384 - RJ, Rel. Min. Nancy Andrighi).

A regra restritiva do artigo 1619, do Código Civil, que estipula que o adotante tenha que ser pelo menos dezesseis anos mais velho que o adotado também vem sendo combatida, lembrando-se casos de uniões entre mulheres mais velhas mães de filhos menores de anterior relacionamento - e homens mais novos (por exemplo, com trinta, quinze, e vinte e oito anos, respectivamente), resultando diferença etária insuficiente à adoção legal, ficando privados os envolvidos, ainda que sob a capa de entidade familiar, de regularizar a situação dos menores que se encontram na sua responsabilidade.

\footnotetext{
${ }^{153}$ Filiação homoafetiva, in Afeto, Ética, Família e o Novo Código Civil Brasileiro - Anais do IV Congresso Brasileiro de Direito de Família, Del Rey, Belo Horizonte, 2004, p. 394.

${ }^{154}$ Repensando o Direito de Família, in Anais do I Congresso Brasileiro de Direito de Família, IBDFAM, Belo Horizonte, 1999, p. 27.
} 
Por evidente, é de se anotar as hipóteses em que a paternidade, ainda que sob vínculos de sangue e dentro da família legal, é de ser afastada judicialmente, como no caso do austríaco Josef Fritzl, de 73 anos de idade, que manteve a filha Elisabeth Fritzl presa no porão de sua casa por 24 anos e a estuprou repetidas vezes, digno de triste menção, em virtude de seus efeitos.

Desaguou a tresloucada prática no nascimento de sete filhos, dos quais três viveram o tempo de suas vidas em cárcere privado, juntamente com a mãe, sendo que um quarto, gêmeo, faleceu ainda no cárcere, e outros três foram "abandonados" pelo pai, pouco após o nascimento, à porta de sua própria residência, a seguir acolhidos como filhos de Josef e sua mulher, que também tinham filhos comuns.

O julgamento, em Sankt Pölten, na Áustria, resultou em pena de prisão perpétua ao réu, mas o aprisionamento vitalício do abjeto ser não apagará, certamente, a monstruosidade que praticou contra sua filha e filhos-netos, também tornados irmãos-sobrinhos, que gerarão, num futuro próximo, tios-primos, todos parentes numa cadeia de maldade que, infelizmente, se protrairá, em efeitos, por várias gerações ${ }^{155}$.

Outros ângulos da questão se abrem pela análise de famoso caso brasileiro, envolvendo Vilma Martins Costa, uma mulher que raptou, em 1979 e 1986, dois recém-nascidos em maternidades, primeiro uma menina - que chamou Roberta, e depois um menino, nomeado Osvaldo, registrando-os e criando-os por vários anos como se filhos seus e de seu marido Osvaldo fossem, quando, na verdade, Aparecida e Pedro (nomes dados pelos pais legais biológicos) eram filhos, respectivamente, de Francisca Maria e seu agora falecido marido e de Maria Auxiliadora e Jairo.

Desmascarada em 2002, Vilma, no entanto, não perdeu o afeto daqueles que criou como se filhos seus fossem, os quais, aliás, declararam publicamente continuar considerando-a como sua verdadeira mãe, em especial Pedro (ou Osvaldo) que, à época menor de idade, preferiu continuar na companhia de Vilma, no que contou com a anuência dos pais legais naturais, por acordo firmado em encontro de todos, tudo transmitido em cadeia nacional de televisão.

\footnotetext{
${ }^{155}$ Veja on line, in http://blogs.abril.com.br/irrecuperavel/2009/03/josef-fritzl-condenado-prisaoperpetua.html.
} 
Contudo, Vilma foi processada pelos crimes cometidos e, no fim de 2003, presa, indo Pedro finalmente residir com seus pais biológicos ${ }^{156}$.

Toda essa situação não foi impedimento, conforme reportagem com ele efetuada em 2005, para que Pedro - ao que parece definitivamente ambientado à sua nova família - continue, porém, referindo-se com carinho a Vilma e Osvaldo (falecido marido dela) e afirmando que ambos permanecerão para sempre também como seus pais ${ }^{157}$.

Esse conjunto de fatores nos leva a concluir que, em matéria de filhos, filiação, deve sempre prevalecer a regra de ouro do melhor interesse da criança e adolescente, com respaldo na teoria da proteção integral, expressamente prevista no Estatuto da Criança e do Adolescente, sendo a solução por critérios biológicos ou socioafetivos possibilidades, mas não imposições, entre as hipóteses que se mostrem para análise.

Resta colocar uma ressalva a plena igualdade constitucional entre filhos: a do filho indigno, em relação aos demais, excluído que fica da sucessão, a teor do artigo 1814, do Código Civil, a comprovar que, tão logo a regra se posta, a exceção também se mostra..

\subsection{FILHOS, PAIS E GUARDA COMPARTILHADA}

Da aplicação dos preceitos constitucionais brasileiros (repisados, entre outros, ser a família base da sociedade; terem homem e mulher igualdade de direitos, assim como não haver distinção entre filhos; ser obrigação da família e do Estado o asseguramento dos direitos fundamentais à criança e ao adolescente, em especial o da convivência familiar), decorre a obrigação do legislador e dos operadores do Direito de, ao se depararem com o fato irreversível da ruptura de um relacionamento em que há filhos, cuidarem para que tais dispositivos sejam obedecidos, seja na confecção de leis regulamentadoras das formas de dissolução e seus consectários, seja na aplicação de ditas leis.

\footnotetext{
${ }^{156}$ Veja on line, in http://veja.abril.com.br/190203/p_070.html.

${ }^{157}$ Veja on line, in http://veja.abril.com.br/020305/auto_retrato.html.
} 
As normas legais brasileiras não impedem aos pais, hoje, estipulação livre sobre o tema da guarda de filhos, apenas dando limites a essa liberdade dentro do interesse do menor que, se entendido pelo Estado, na pessoa do juiz, como não suficientemente resguardado, poderá ser objeto de intervenção, em atendimento ao princípio da proteção integral.

Todavia, nosso legislador é fértil e inquieto: desse modo, desde o advento do novo Código Civil, não poderiam faltar alguns projetos de lei, como se seguiram, específicos sobre guarda compartilhada, que resultaram na edição da Lei Ordinária sob $n^{\circ}$ 11.698, de 13 de junho de 2008, publicada no DOU de 16 de junho de 2008, com vigência a partir de 16 de agosto de 2008 - A Lei da Guarda Compartilhada, a seguir brevemente comentada ${ }^{158}$.

De início, vê-se repetido, na redação final da lei, o mesmo erro técnico, dos projetos de origem: de se colocar definição de instituto dentro do texto legal, o que impede o exercício de exegese, tão salutar e necessário, principalmente no campo do Direito de Família, extremamente sensível a mudanças sociais.

Aliás, incompreensível a lógica utilizada para se lançar, nos projetos e na lei, definição de guarda compartilhada, se, antes, num dos votos em separado da Câmara, propugna a Deputada Jandira Feghali que "no campo do direito de família, a norma legal deve ser aberta de maneira a contemplar sempre o caso concreto e ao contemplar um caso de guarda de filhos a regra de ouro é sempre o interesse dos filhos. E esse interesse deve ser estudado caso a caso, devendo o juiz utilizar-se de mecanismos técnicos para tal como os estudos social e psicológico.”.

Não bastasse, a definição lançada é uma má definição. Fala-se da guarda compartilhada como "a responsabilização conjunta e o exercício de direitos e deveres do pai e da mãe", quando aceitável seria dizer "a responsabilidade conjunta ... dos pais", pois qualquer que seja o tipo de guarda não se presta ele somente a "responsabilizar" os pais, mas sim a dar a eles responsabilidades, coisa algo diversa. Ademais, é conservadora, ao mencionar "pai" e "mãe" e não a genérica expressão "pais", afastando de sua abrangência, ao menos em tese, a grupo formado por homossexuais e seus filhos.

\footnotetext{
${ }^{158} \mathrm{O}$ texto integral da Lei de Guarda Compartilhada está contido no Anexo A da presente tese.
} 
Insistindo-se na colocação de conceitos na lei, com deficientes definições de guarda unilateral e compartilhada, inclui, ademais, fatores sobremaneira subjetivos como se apurar "objetivamente" qual dos pais revela "mais aptidão para propiciar...afeto...saúde...segurança...educação".

Decreta-se, ainda, que a partir da vigência da lei haverá apenas dois tipos de guarda - unilateral ou compartilhada, o que, à evidência, não corresponde à realidade, posto que bem conhecida uma multiplicidade de tipos de guarda, não sendo correta a utilização de expressões que já contém, dentro delas, conceitos assentados e de há muito utilizados pela doutrina e jurisprudência, em outro sentido, mais amplo e sem qualquer respeito à técnica jurídica e, pior, à vontade dos pais e o interesse da criança, hoje contemplados no Código Civil.

Coloca, de forma indireta, ainda, o genitor não guardião no inferior papel de "supervisionar os interesses dos filhos", contrariando, nesse passo, o expresso teor dos artigos 1632 e 1634, do Código Civil, de maior abrangência.

Abre aos pais, também, a nefasta possibilidade de ser requerida "por qualquer deles" a guarda compartilhada, litigiosa, e mesmo de ser ela "decretada" pelo juiz sem que haja pedido ou mesmo intenção manifestados nesse sentido, quando até a mais atual e liberal jurisprudência tem entendido não ser tal juridicamente possível $^{159}$.

Não bastasse, utiliza-se a "redução de prerrogativas...inclusive...de convivência com o filho" como fator de punição ao genitor, sem atinar que deve sempre prevalecer o interesse superior em jogo, do menor, além do que indevida a colocação do exercício do poder familiar como "prerrogativa", do que, certamente, não se trata.

E, entre tantas palavras, nada se disse a respeito da guarda física, a guarda de fato; não esclareceu, enfim, se a posse habitual dos filhos estaria ressalvada do compartilhamento.

Ainda uma vez, restou, para o entendimento do sentido das palavras como colocadas no texto, socorrermo-nos do teor do voto em separado da antes referida deputada Jandira Feghali, que acompanha a inicial proposta da Câmara, lá se

\footnotetext{
${ }^{159}$ Apelação Cível No 70007455926, Oitava Câmara Cível, Tribunal de Justiça do RS, Relator: Rui Portanova, julgado em 18/12/2003.
} 
encontrando que " a expressão 'guarda compartilhada' poderia ser confundida com 'guarda alternada', o que acarretaria um entendimento de que a guarda dos filhos se daria em formato que resultaria numa falta de estabilidade para os filhos de pais separados, no que diz respeito à sua própria casa ... no modelo de guarda compartilhada ou conjunta, apesar da criança residir com um dos pais, deve-se garantir uma convivência ampliada com ambos os genitores, responsáveis pela educação da criança.”. Pena que a lei não tenha ficado clara como o é a exposição de motivos dos projetos de origem.

No mais, só faz repetir, inutilmente, em outra ordem, o já contido no novo Código Civil.

A nova lei, por todos esses aspectos, me parece equivocada e desnecessária, certo que gerará necessidade de novos esforços doutrinários e jurisprudenciais para uma interpretação adequada de texto tão carente de técnica, e resultará em risco de perda do valioso acervo jurídico que já existe assentando o tema, uma vez que, como já explanado, o ordenamento atual não veda (e nem os anteriores vedavam, diga-se) acordo contendo guarda compartilhada. Apenas são enxergadas restrições nos casos judiciais, de litígio, até porque o espírito do compartilhamento não se coaduna com tais hipóteses, muito menos se for imposto aos pais.

\subsection{CIÊNCIA MÉDICA E FILIAÇÃO}

Qualquer pessoa que tenha tido algum contato com o Direito de Família já terá ouvido falar das presunções pater is est, mater semper certa est e exceptio plurium concubentium entre as mais conhecidas na matéria.

Tais presunções, criadas para resolver questões jurídicas que se apresentavam por vezes intransponíveis, vieram a ser profundamente questionadas após o advento das novas técnicas da ciência para descoberta da filiação biológica, a ponto de se desprezar como legal qualquer outro fundamento que não aquele imposto pelo determinismo científico da genética. 
Porém, as mesmas técnicas científicas, logo depois, trouxeram novas perplexidades e a necessidade de se recorrer a também novas presunções, ainda uma vez para solver dilemas para os quais o Direito não tem, ainda, satisfatória resposta.

No assunto, José Fernando Simão aduz que "no embate entre a parentalidade biológica (DNA) e a socioafetiva (afeto), nada está decidido. Em se tratando de erro do pai, prevalece o aspecto biológico e vence o DNA. Entretanto, se houver reconhecimento voluntário de filho alheio, o pai não poderá negar a paternidade, sob pena de agredir a boa-fé objetiva, como norma ética de conduta. Prevalece o afeto sobre o DNA"160.

Assim é que o artigo 1597, do Código Civil, estabelece presumirem-se concebidos na constância do casamento os filhos havidos por fecundação artificial homóloga, mesmo que falecido o marido (inciso III); os havidos a qualquer tempo, quando se tratar de embriões excedentários, decorrentes de concepção artificial homóloga (inciso IV); e os havidos por inseminação artificial heteróloga, desde que com prévia autorização do marido (inciso V).

Um primeiro problema é o decorrente da utilização de gametas e embriões excedentários envolvendo pessoa falecida.

No caso do homem, a utilização do sêmen, após sua morte, só pode ser autorizada ao cônjuge sobrevivente se assim havia, em vida, expressamente autorizado o consorte, até em obediência ao mandamento constitucional que estabelece ser o planejamento familiar livre decisão do casal.

No caso da mulher, seus óvulos fecundados, igualmente, só poderão ser implantados em útero alheio (a conhecida "barriga de aluguel), se assim por ela consentido e, mais, nessa hipótese, somente podendo ser a cedente do útero parente colateral até o segundo grau da mãe genética, conforme norma ética consubstanciada na Resolução n. 1358, de 1992, do Conselho Federal de Medicina.

Outra questão, que se mistura, de certa forma, com a anterior, é a gerada pelos artigos 1601 e 1608, ambos do Código Civil, que rezam, o primeiro, ser imprescritível a impugnação de paternidade; o segundo, que a mãe pode refutar a maternidade provando falsidade do termo de nascimento, dessa combinação podendo

\footnotetext{
${ }^{160}$ Parentalidade: o duelo DNA $x$ afeto - parte II, in Carta Forense, São Paulo, ed. 67, dez/2008, p. 17.
} 
mesmo haver hipótese de filhos de ninguém, ou seja, indivíduos biologicamente gerados, mas sem (ou destituídos de) ascendentes juridicamente reconhecidos.

Luiz Edson Fachin escreve sobre esses, que designa "não filhos", observando que, no caso, “criou-se, assim, uma espécie de suspensão permanente nas relações jurídicas paterno-filiais e materno-filiais", advertindo, porém, que "essa migração dos filhos excluídos por ilegitimidade para os não filhos nisso que vem se chamando de complexa pós-modernidade não pode conduzir à filiação por eleição ou escolha"161.

Nesse momento, pertinente serem relembrados os retro citados casos dos pares homoafetivos formados por dois homens que adotaram uma menina, e outros dois que adotaram nada menos que quatro irmãos, além daquele de duas brasileiras, uma delas agora grávida de gêmeos gerados da fertilização artificial dos óvulos de seu par com sêmen de um doador desconhecido, e do transexual americano operado para fixação do caráter masculino, considerado predominante - mas sem retirada dos órgãos reprodutores internos femininos que possuía -, após legalmente reconhecido homem e casado com mulher que efetuou histerectomia, resolvendo ele (ela?) engravidar, cessando tratamento hormonal e fazendo inseminação artificial, estando grávido (grávida?) de uma menina.

Naturalmente sem prejuízo das considerações sobre a atitude dos envolvidos, incluindo os profissionais técnicos responsáveis, a verdade é que as crianças já adotadas e as outras que surgirão nenhuma culpa têm pelos reflexos de ordem ética, moral e jurídica acarretados e devem ter seus direitos imediatamente reconhecidos e integralizados.

Os princípios e teses, nesse momento ímpar em que estão em jogo os interesses da criança, hão de ceder espaço às inevitáveis soluções pontuais, autênticas tábuas de salvação cuja posse deve ser garantida à criança, justificando-se nesse embate, caso necessário, fazer perecer o Direito, para que, no húmus que se forme dos restos de tal morte, floresça, viçosa, a Justiça e dela, renasça, então, um revigorado Direito.

${ }^{161}$ O Código Civil e o desassossego da filiação, in Carta Forense, São Paulo, ed. n. 57, fev/2008, p. 48. 


\section{CAPÍTULO IV.}

\section{ANTEPROJETOS - BREVES COMENTÁRIOS}

De tudo o até aqui visto percebe-se claramente que a sociedade modificou profundamente sua ótica no que concerne ao tema da família, não mais lhe atribuindo os mesmos papéis (de procriação, político, religioso e econômico) do passado.

A revolução industrial e a marcha feminina rumo a sua total emancipação deitaram por terra os sustentáculos da sociedade patriarcal e, conseqüentemente, dos núcleos familiares nela apoiados.

$\mathrm{Na}$ atualidade, é na solidariedade, prevista constitucionalmente, que deve dar-se a convivência do grupo que pretenda se intitular como família, de forma a que seus componentes, dentro dos preceitos de justiça e liberdade, possam alcançar sua realização pessoal.

Mas, se solidariedade, justiça e liberdade são os blocos formadores do que a sociedade brasileira expressamente definiu como sendo sua base - a família -, a argamassa que os liga é uma só - o afeto -, "elemento nuclear e definidor da união familiar, aproximando a instituição jurídica da instituição social. A afetividade é o triunfo da intimidade como valor, inclusive jurídico, da modernidade." ${ }^{162}$.

E assim sendo, a família realiza, agora, um movimento de individualização, como aquele das células que, para formar um ser completo, libertam-se daquela primeira, surgida da união de gametas, e assumem identidade e função própria, ao lado de inúmeras outras que, multiplicando-se mais e mais, terminam por formar um todo só, complexo, no qual ele depende delas e elas dele, tal qual o indivíduo, a família e o Estado.

Porém, dentro de cada célula, deve restar preservado o que de mais íntimo é do ser humano - o amor, o afeto -, posto a salvo da intervenção do Estado, pois que se acha incluso, na feliz expressão de Jean Carbonnier, no non-droit ${ }^{163}$.

\footnotetext{
${ }^{162}$ Famílias cit. (nota 31 supra) p. 15.

${ }^{163}$ Flexible... cit. (nota 97 supra).
} 
Alçando-se a dignidade humana das profundezas do oceano patrimonial em que se via submersa, dá-se novo destaque ao indivíduo e ao Direito, pois esse passou a defender aquele e a seus fins, e não mais exclusivamente o valor econômico que ele possa representar.

É a reengenharia do individualismo e do humanismo, "a repersonalização ... a realização da afetividade pela pessoa no grupo familiar, no humanismo que só se constrói na solidariedade - no viver com o outro"164.

Não é por outra razão que tantos queiram ser reconhecidos como integrantes de uma família, tantos clamem por que lhes seja dada oportunidade de serem enxergados como seres sociais completos, tantos desejem ser recebidos com amor e respeito no seio da comunidade, e para ela, darem, em retribuição, o que de melhor está ao seu alcance, na infindável tarefa de transformar o mundo, pelas pessoas, num lugar digno de se viver e conviver.

E o Direito não pode estar inerme no momento de se fazerem concretos os legítimos anseios dos indivíduos, razão do que se estruturou a presente com objetivo de por a mostra as armas já existentes e à disposição para que se faça a necessária revolução social.

Entram em cena, então, os legisladores, cuja função é a de transformar em lei os anseios da sociedade, certo que, em matéria de entidades familiares e filiação há vários projetos de lei em andamento, destacando-se entre eles os dos Deputados Federais Marta Suplicy, Clodovil Hernandes, Cândido Vaccarezza, Sérgio Barradas Carneiro, Walter Brito Neto e Olavo Calheiros, a seguir, em ordem de propositura, brevemente comentados.

De início, vemos o Anteprojeto de Lei n. 1151/95 ${ }^{165}$, respeitante a parceria civil registrada entre pessoas do mesmo sexo, que evita colocar a parceria civil homossexual no mesmo pé de igualdade das entidades familiares, naturalmente como forma de se contornar uma intransponível barreira à sua aprovação, vez que a matéria é muito controvertida e a maioria do Congresso revela-se contrária a tal pretensão.

\footnotetext{
${ }^{164}$ Famílias cit. (nota 31 supra) p. 16.

${ }^{165}$ O Projeto de Lei $1151 / 95$ e seu substitutivo constam, na íntegra, do Anexo B, sob n. 1, desta.
} 
Num tom menor, procura resguardo e regulamentação dos efeitos dos atos jurídicos hoje praticados por tais parceiros (propriedade, sucessão), vedando a eles a adoção, tutela e guarda conjuntas, ainda que de prole dos contratantes, e tornando inalterado o estado civil dos mesmos durante a vigência do contrato da parceria decorrente.

É incongruente, contudo, nesse passo mostrando as reais intenções por trás dele, ao exigir, para sua confecção, declaração do estado civil, admitidos à contratação apenas solteiros, viúvos ou divorciados.

Desautoriza, de outra parte, qualquer liame de parentesco quer entre os parceiros, entre si, quer entre seus parentes, enfatizando a criação de um livro próprio, diverso do destinado às entidades familiares, para registro da parceria.

Veda a pluralidade de contratos da espécie, sob o manto de resguardo de direitos patrimoniais, mas deixa aí transparecer forma de instituição de dever de fidelidade.

Também no intento de não se aproximar da forma das entidades familiares, não prevê prazo para a duração e desconstituição do contrato, estabelecendo regra específica quanto ao tratamento dos direitos previdenciários, para distanciar-se daqueles previstos aos cônjuges e companheiros.

Estipula direitos específicos outros, como a instituição de bem de família, de direitos previdenciários, incluindo pensão por morte, direito à sucessão, em total similitude com os da companheira, preferência na curatela do parceiro, direito à naturalização decorrente da parceria, direitos habitacionais e de dependência especial para efeitos tributário, securitário e de saúde.

Por assim se estender e deixar, nas entrelinhas, abertas portas para inevitáveis interpretações, recebeu votos em separado acidamente contrários e, da forma como vazado, não se vislumbra qualquer hipótese de que seja, afinal, aprovado.

O anteprojeto de lei 580/07 $7^{166}$, do falecido Deputado Clodovil Hernandes, simples reapresentação de anterior da Deputada Laura Carneiro, bastante sucinto, é ainda mais aberto a interpretações que o anterior comentado, além de prever,

${ }^{166}$ O Projeto de Lei 580/07 e seus votos constam, na íntegra, do Anexo B, sob n. 2, desta. 
expressamente, união homoafetiva, em paralelo com a união estável; refere-se, ainda, a companheiros homossexuais, novamente utilizando-se da mesma designação dada às pessoas em união estável.

Assim, sofre de igual resistência no Congresso, além de, por mais genérico, ser tecnicamente inadequado aos fins a que se dispõe.

O anteprojeto 674/07 $7^{167}$, do Deputado Federal Cândido Vacarrezza, de forma mais incisiva, prevê que a união estável entre duas pessoas (e não mais homem e mulher) é reconhecida como entidade familiar, daí decorrendo, por coerência, instituição de direitos aos pares homossexuais iguais aos heterossexuais, obtendo longos votos favoráveis e desfavoráveis, com indicação de mesma sorte dos que o precederam - rejeição.

Já o anteprojeto do Deputado Sérgio Barradas Carneiro, sob n. 2285/07"168, que dispõe sobre o "Estatuto das Famílias" é mais elaborado e abrangente, propondo a criação de um novo subsistema, que pretende regular "os direitos e deveres no âmbito das entidades familiares".

Mas, conforme se percebe já de suas disposições gerais, é fundamentalmente voltado a "igualdade de gêneros", "respeito à diversidade de orientação sexual", instituindo parentesco pela "consangüinidade", "socioafetividade" e "afinidade".

Abre oportunidade aos pares homossexuais casarem-se, por não referir ao binômio "homem" e "mulher" nesse particular, ainda que o exija para o que desejem unirem-se estavelmente, o que constitui evidente contradição.

Como os demais, portanto, está fadado ao insucesso, não só por não se afinar com o pensamento da maioria parlamentar, como por conter, na tentativa abarcar toda uma sensível e difícil área do Direito, como é a do Direito de Família, uma série de contradições e colocações destituídas da melhor técnica.

O anteprojeto do Deputado Walter Brito Neto, que tomou o n. 3323/08 ${ }^{169}$, tem um só objetivo: "vedar a adoção por casal do mesmo sexo".

\footnotetext{
${ }^{167}$ O Projeto de Lei 674/07 e seus votos constam, na íntegra, do Anexo B, sob n. 3, desta. ${ }^{168}$ O Projeto de Lei 2285/07 e seus votos constam, na íntegra, do Anexo B, sob n. 4, desta.

${ }^{169}$ O Projeto de Lei 3323/07 consta, na íntegra, do Anexo B, sob n. 5, desta.
} 
E, conquanto sua matéria seja, ao contrário dos outros, de boa receptividade junto aos seus pares, peca ele por princípio - querer denominar, expressamente, em lei, os pares homossexuais de "casal do mesmo sexo".

Talvez algum substitutivo venha corrigir esse "deslize" do proponente, e o anteprojeto vá à frente com alguma possibilidade de aprovação.

Por fim, o anteprojeto de lei mais recente de que temos conhecimento, do Deputado Federal Olavo Calheiros, que assumiu o n. 4508/08 ${ }^{170}$, "proíbe a adoção por homossexuais", fixando de forma expressa que a adoção somente poderá ser requerida por pessoas maiores de idade e oficialmente casadas, exigida, ainda, estabilidade familiar e, sendo adotado na total rigidez, representará um enorme retrocesso no instituto da adoção, afastando os solteiros e os companheiros do direito, extremo que, igualmente, não pode ser aceito.

Esses os resumidos comentários às iniciativas legislativas atuais que, como se percebe, não têm, quer na sua estrutura, quer no seu conteúdo, a desejada técnica, o que muito esclarece, aliás, sobre a presente situação do nosso sistema jurídico, uma autêntica colcha de retalhos, onde convive um novo e já velho sistema de Código Civil com inúmeros microssistemas satélites, cuja estabilidade a todo o momento vem sendo posta à prova, em jogo de forças de resultados imprevisíveis.

\footnotetext{
${ }^{170}$ O Projeto de Lei 4508/08 consta, na íntegra, do Anexo B, sob n. 6, desta.
} 


\section{CONCLUSÕES}

1. A família compõe-se de dados naturais, não sendo criada, mas apenas formatada, pelo Direito, necessitando, por sua constante mutação, políticas legislativas que acompanhem esse movimento evolutivo.

2. A Constituição Federal confere papel destacado à família atual, estabelecendo ser ela base da sociedade. Todavia, o descompasso entre a realidade social e a legislação vigente, em matéria de família, provoca discriminações e desigualdades, devendo o modelo clássico, patrimonialista, ceder espaço a outro, baseado nos laços socioafetivos.

3. A sociedade apresenta, hoje, grupos de indivíduos não enquadrados no rol estabelecido como legal pelo Estado e este, na tentativa de ordenar tais grupos, passa a criar microssistemas para regular os conflitos, gerando instabilidades no sistema jurídico principal.

4. O Direito de Família passou a dar especial importância à preservação dos vínculos familiares, aos direitos e deveres que ligam os indivíduos entre si e com seus filhos, à formação de indivíduo apto a gerar novo núcleo familiar, para tanto promovendo a igualdade entre homem e mulher e entre todos os filhos, assumindo o casal, mutuamente os encargos da família, incluindo-se neles o exercício conjunto e equânime do poder familiar.

5. Os princípios constitucionais, à falta de normas específicas, vem em socorro dos intérpretes, na busca de soluções eficazes e coerentes para os problemas da família, com destaque aos da dignidade da pessoa humana, da solidariedade, da igualdade, da liberdade, da afetividade, da convivência familiar, do melhor interesse da criança e do adolescente e da segurança jurídica, circunstância que, contudo, provoca indevido deslocamento do debate do Direito Civil para o Direito Constitucional.

6. Os princípios constitucionais não devem ser considerados de forma isolada e absoluta na reengenharia do sistema jurídico, mas de forma interdependente e 
obedecendo ao denominado "juízo de ponderação", não podendo ser aplicados como panacéia, sob pena de, por desmedido uso, tornarem-se ineficazes, não contribuindo, assim, para a almejada evolução e interação uniforme do referido sistema.

7. A afetividade é uma presunção legal que gera deveres decorrentes dos vínculos de família formados através das relações socioafetivas e da comunhão de vida, e representa a prevalência do valor da pessoa humana sobre os valores materiais, patrimoniais, nas relações familiares, deveres esses impostos a par da existência, ou não, de amor ou afeição entre as pessoas envolvidas.

8. O princípio da segurança jurídica é, dentro do conjunto de princípios constitucionais, aquele dotado de força reguladora garantidora, ao indivíduo, da vinculação dos seus direitos, posições e relações jurídicas validamente normatizados, aos efeitos previstos nas respectivas normas legais, impedindo excessos interpretativos.

9. Na constituição do conceito da família deve se ter em consideração não só elementos subjetivos, mas também fatores objetivos, delimitadores da sua extensão, pois a aplicação do pluralismo absoluto às entidades familiares resultaria em choque com a ordem social vigente, sendo o convívio social, a efetividade dos liames familiares e a afetividade condições que devem estar presentes para a identificação do grupo como familiar.

10. Os princípios da dignidade da pessoa humana e da afetividade, vistos sob ângulo individualista, não são suficientes para justificar inclusão de grupos não previstos como entidade familiar, porque há outros direitos fundamentais sociais de igual peso em colisão com tal pretensão e, da harmonização dos direitos em conflito, na atual formatação constitucional, resultam como entidades familiares aquelas elencadas na Constituição.

11. Na família patriarcal, a idéia de agrupamento familiar tinha como função principal a manutenção da sua força econômica, como forma de perenizá-lo. Tal visão tradicional, biológica e patrimonialista, ainda hoje gera efeitos, mas, 
paulatinamente, vem dando lugar à repersonalização da família, pela volta da importância do indivíduo nas relações familiares, agora nutridas pelo afeto mútuo.

12. As conquistas científicas, em matéria de reprodução, mudaram de forma radical a visão puramente biológica da formação da família, dando lugar a liames não biologizados, afetivos e, embora a legislação brasileira não faça menção aos sentimentos de afeto e amor, é na solidez deles que deve fundar-se a estrutura familiar e através deles é que deve ser formado o indivíduo no seio da família, em atenção ao princípio da defesa da afetividade.

13. A síntese dos indicadores sociais da população brasileira de 2008 mostra que o casamento entre homem e mulher permanece amplamente prestigiado, dentro de uma visão religiosa predominantemente cristã, com formação principal dentro de vínculos de consangüinidade, representando avanço a aceitação dos divorciados para novo enlace legal, constantes o declínio da taxa de fertilidade e o aumento da idade populacional, o que, em alguns anos, causará problemas nos setores econômicos, previdenciários e de saúde, quadro que restaria agravado pela inclusão de grupos sociais dentro da esfera da especial proteção do Estado reservada à família.

14. É dever do Estado propiciar instrumentos de proteção à mulher separada e divorciada com filhos, pois é essa que continua principal responsável pela prole ao fim da vida em comum do casal, devendo ser dada atenção, igualmente, ao aumento do número de famílias monoparentais que, pela própria estrutura, demanda maior assistência governamental.

15. Reduzir a entidade familiar a um núcleo duro, impermeável, sem interligação com a sociedade que, como base, deve sustentar, seria como decretar a morte da família ou, no menos, abrir campo para que a sociedade termine por eleger para si outra base de sustentação, retirando do indivíduo o seu ponto de referência, onde ele nasce, cresce, desenvolve a afetividade e se socializa (através do aprendizado moral e intelectual), do que ficaria negada, assim, a função social da família brasileira.

16. Prestar especial enfoque à entidade familiar não significa retirar aos indivíduos, vistos individualmente, quaisquer direitos fundamentais (ou humanos, 
como se queira), mas indica que, dentro de uma ordem social, há eleição de prioridades e imposição de regras para garantir o seu alcance.

17. Não cabe, no Direito brasileiro, declaração de inconstitucionalidade de norma constitucional, em obediência ao princípio da unidade hierárquico-normativa da Constituição, devendo ser os eventuais choques de dispositivos resolvidos através do exercício de "relação de prevalência" entre os direitos envolvidos, por ponderação e concordância entre esses. Não se podendo cogitar, então, de normas constitucionais originárias inconstitucionais, é decorrência o afastamento das teses que, por tal ângulo, visam fulminar os dispositivos legais, tanto constitucionais quanto infraconstitucionais, que atribuem determinados direitos (e deveres, lembre-se) expressa e exclusivamente ao casal formado por pessoas de distintos sexos.

18. É justo garantir aos grupos de indivíduos que não se enquadram na definição legal de entidade familiar respeito às suas destacadas dignidade, igualdade e liberdade, reconhecendo suas ligações afetuosas através dos regramentos já existentes - da sociedade de fato - e, embora não recepcionados pelo Direito de Família, a eles sejam garantidos direitos de natureza patrimonial, bem assim de ordem previdenciária.

19. Afastadas do conceito de entidade familiar estão as uniões concubinárias, posto que faltante ao concubinato a idéia de compromisso e, numa sociedade que erigiu a monogamia ao status de "quase-princípio", patente o interesse do Estado em garantir forma estável à família, através da proibição da multiplicidade de relações matrimoniais.

20. As entidades familiares que hoje estão a merecer a especial proteção estatal constitucionalmente garantida são aquelas expressamente mencionadas no texto constitucional, ressalvado, entretanto, o direito a que determinados grupos, em presentes determinados requisitos, sejam conferidos direitos. As entidades familiares assim propriamente consideradas é que devem, atualmente, ser analisadas dentro de um novo conjunto paradigmático, descabidas as sujeições paternalistas e patrimonialistas do indivíduo para que se faça sua inclusão na família, colocados os direitos-deveres do grupo familiar a serviço da humanização do vínculo ali existente. 
21. O Direito de Família não costuma ser uma ciência de invenções. Antes, trabalha tendo em conta o fato e sua dimensão social, pois passa o fato a ter interesse na medida de seus efeitos na sociedade e da necessidade de seu regramento, para que atinja uma determinada finalidade ou não venha a ferir o conjunto de interesses do grupo social no qual ocorre. Assim, não se espera, do Direito de Família, que venha ele a criar uma nova espécie de vida, uma nova raça, um novo sexo, enfim, um novo indivíduo, até porque o indivíduo existe antes do Direito e, inclusive, é o Direito que depende da associação de mais de um indivíduo para que possa, então, surgir como ciência e instrumento de pacificação dos conflitos oriundos desse relacionamento.

22. Sendo a figura do filho dotada de interesses maiores - naturais, materiais, morais, sociais e afetivos, aliás, na forma contida na Constituição brasileira, é de ser considerado ele sujeito de direito, devendo o interesse superior da criança merecer consideração primordial no debate da questão familiar (teoria da proteção integral).

23. O poder familiar é o conjunto de direitos e deveres ligados entre si de forma indissolúvel, existentes entre pais e filhos, tendentes a manter a organização natural, material, moral, social e afetiva da família, com ênfase na proteção integral da prole e mediante o auxílio solidário da sociedade e do Estado.

24. Os princípios da dignidade da pessoa humana, da igualdade, da liberdade, da solidariedade, da afetividade, da convivência familiar, do melhor interessa da criança e do adolescente e da segurança jurídica, favorecem a satisfação dos mais diversos interesses filiais, como os ligados à plena equalização de direitos, à identidade, à personalidade, à saúde e à cidadania, entre outros. A filiação socioafetiva, patenteada na adoção legal, na chamada "adoção à brasileira" e na concepção por inseminação artificial heteróloga, não mais é objeto de contestação social, a par dos inúmeros problemas jurídicos que a circundam, e o reconhecimento do vínculo filial através da figura da posse do estado de filho vem ganhando cada vez mais adeptos.

25. Em matéria de filiação deve sempre prevalecer a regra de ouro do melhor interesse da criança e adolescente, com respaldo na teoria da proteção integral, expressamente prevista no Estatuto da Criança e do Adolescente, sendo a solução por 
critérios biológicos ou socioafetivos possibilidades, mas não imposições, entre as hipóteses que se mostrem para análise.

26. A guarda compartilhada pressupõe colaboração efetiva entre os pais, o que resultaria em diminuição dos conflitos, minimizando a possibilidade de ocorrência de desajustes e problemas emocionais, escolares e sociais nos filhos, além de diminuir a sensação de perda e rejeição por parte da prole. Todavia, o modelo de guarda compartilhada só funciona adequadamente com pais cooperativos, dispostos e aptos a colocarem os interesses dos filhos acima dos seus próprios; que consigam manter o mínimo diálogo e atitudes comuns nos assuntos do poder familiar, sendo erro da lei previsão de guarda compartilhada imposta.

27. A guarda compartilhada não se presta a ser instrumento juridicamente possível, dentro das modalidades de guarda legal estipuláveis em todas as separações, divórcios e dissoluções de união estável e de sociedade de fato, mas tão só naquelas em que haja consenso e um regramento mínimo que assegure as relações paterno-filiais - em atenção ao espírito da teoria da proteção integral, sendo a guarda compartilhada arquétipo ideal apenas em situações em que os envolvidos, mercê do bom senso, sequer necessitariam de regras fixas para o exercício da guarda.

28. Ainda que considerados antiéticos, imorais e ilegais alguns dos mecanismos técnicos de criação de vínculo filial, devem as crianças neles envolvidas ter seus direitos imediatamente reconhecidos e integralizados, posto que essas nesses nenhuma culpa têm pelos reflexos de ordem ética, moral e jurídica acarretados. Os princípios e teses, nesse momento ímpar em que estão em jogo os interesses da criança, hão de ceder espaço às inevitáveis soluções pontuais, autênticas tábuas de salvação cuja posse deve ser garantida à criança, justificando-se nesse embate, caso necessário, fazer perecer o Direito, para que, no húmus que se forme dos restos de tal morte, floresça, viçosa, a Justiça e dela, renasça, então, um revigorado Direito.

29. Os projetos de lei e seus substitutivos, sobre família, atualmente em tramitação no Congresso, são iniciativas legislativas equivocadas, por contrariarem a regra de não dever a lei conter conceitos sobre os institutos de que trata, nem trazer 
incoerências e inconsistências, erros esses todos constantes dos textos em tramitação, do que devem ser profundamente alterados ou rejeitados. 


\section{ANEXO A - LEI SOBRE A GUARDA COMPARTILHADA}

\section{LEI N 11.698 , DE 13 DE JUNHO DE 2008}

Altera os arts. 1.583 e 1.584 da Lei no 10.406, de 10 de janeiro de 2002 - Código Civil, para instituir e disciplinar a guarda compartilhada.

\section{O PRESIDENTE D A REPÚB LIC A}

Faço saber que o Congresso Nacional decreta e eu sanciono a seguinte Lei:

Art. $1^{\circ}$ Os arts. 1.583 e 1.584 da Lei no 10.406, de 10 de janeiro de 2002 - Código Civil, passam a vigorar com a seguinte redação:

“Art. 1.583. A guarda será unilateral ou compartilhada.

$\S 1^{\circ}$ Compreende-se por guarda unilateral a atribuída a um só dos genitores ou a alguém que o substitua (art. 1.584, $\S 5^{\circ}$ ) e, por guarda compartilhada a responsabilização conjunta e o exercício de direitos e deveres do pai e da mãe que não vivam sob o mesmo teto, concernentes ao poder familiar dos filhos comuns.

$\S 2^{\circ} \mathrm{A}$ guarda unilateral será atribuída ao genitor que revele melhores condições para exercê-la e, objetivamente, mais aptidão para propiciar aos filhos os seguintes fatores:

I - afeto nas relações com o genitor e com o grupo familiar;

II - saúde e segurança;

III - educação.

$\S 3^{\circ} \mathrm{A}$ guarda unilateral obriga o pai ou a mãe que não a detenha a supervisionar os interesses dos filhos.

$\S 4^{\circ}$ (VETADO).” (NR)

“Art. 1.584. A guarda, unilateral ou compartilhada, poderá ser: 
I - requerida, por consenso, pelo pai e pela mãe, ou por qualquer deles, em ação autônoma de separação, de divórcio, de dissolução de união estável ou em medida cautelar;

II - decretada pelo juiz, em atenção a necessidades específicas do fillho, ou em razão da distribuição de tempo necessário ao convívio deste com o pai e com a mãe.

$\S 1^{\circ} \mathrm{Na}$ audiência de conciliação, o juiz informará ao pai e à mãe o significado da guarda compartilhada, a sua importância, a similitude de deveres e direitos atribuídos aos genitores e as sanções pelo descumprimento de suas cláusulas.

$\S 2^{\circ}$ Quando não houver acordo entre a mãe e o pai quanto à guarda do filho, será aplicada, sempre que possível, a guarda compartilhada.

$\S 3^{\circ}$ Para estabelecer as atribuições do pai e da mãe e os períodos de convivência sob guarda compartilhada, o juiz, de ofício ou a requerimento do Ministério Público, poderá basear-se em orientação técnico-profissional ou de equipe interdisciplinar.

$\S 4^{\circ}$ A alteração não autorizada ou o descumprimento imotivado de cláusula de guarda, unilateral ou compartilhada, poderá implicar a redução de prerrogativas atribuídas ao seu detentor, inclusive quanto ao número de horas de convivência com o filho.

$\S 5^{\circ}$ Se o juiz verificar que o filho não deve permanecer sob a guarda do pai ou da mãe, deferirá a guarda à pessoa que revele compatibilidade com a natureza da medida, considerados, de preferência, o grau de parentesco e as relações de afinidade e afetividade." (NR)

Art. $2^{\circ}$ Esta Lei entra em vigor após decorridos 60 (sessenta) dias de sua publicação.

Brasília, 13 de junho de $2008 ; 187^{\circ}$ da Independência e $120^{\circ}$ da República.

LUIZ INÁCIO LULA DA SILVA

Luiz Paulo Teles Ferreira Barreto

José Antonio Dias Toffoli 


\section{ANEXO B - ANTEPROJETOS DE LEI SOBRE FAMÍLIA}

\section{Projeto MARTA SUPLicy}

\section{PROJETO DE LEI N ${ }^{\circ} 1.151$, DE 1995}

Da Deputada Federal Marta Suplicy

Disciplina a união civil entre pessoas do mesmo sexo e dá outras providências.

O Congresso Nacional decreta:

Art. $1^{\circ}$ - É assegurado a duas pessoas do mesmo sexo o reconhecimento de sua união civil, visando a proteção dos direitos à propriedade, à sucessão e dos demais assegurados nesta Lei.

Art. $2^{\circ}$ - A união civil entre pessoas do mesmo sexo constitui-se mediante registro em livro próprio, nos Cartórios de Registro de Pessoas Naturais.

$\S 1^{\circ}$ - Os interessados e interessadas comparecerão perante os oficiais de Registro Civil exibindo:

I - prova de serem solteiros ou solteiras, viúvos ou viúvas, divorciados ou divorciadas;

II - prova de capacidade civil plena;

III - instrumento público de contrato de união civil.

$\S 2^{\circ}$ - O estado civil dos contratantes não poderá ser alterado na vigência do contrato de união civil.

Art. $3^{\circ}$ - O contrato de união civil será lavrado em Ofício de Notas, sendo livremente pactuado. Deverá versar sobre disposições patrimoniais, deveres, impedimentos e obrigações mútuas.

Parágrafo único - Somente por disposição expressa no contrato, as regras nele estabelecidas também serão aplicadas retroativamente, caso tenha havido concorrência para formação do patrimônio comum.

Art. $4^{\circ}$ - A extinção da união civil ocorrerá:

I - pela morte de um dos contratantes;

II - mediante decretação judicial.

Art. $5^{\circ}$ - Qualquer das partes poderá requerer a extinção da união civil:

I - demonstrando a infração contratual em que se fundamenta o pedido; 
II - alegando desinteresse na sua continuidade.

$\S 1^{\circ}$ - As partes poderão requerer consensualmente a homologação judicial da extinção da união civil.

$\S 2^{\circ}$ - O pedido judicial de extinção da união civil, de que tratam o inciso II e o $\S 1^{\circ}$ deste artigo, só será admitido após decorridos 2 (dois) anos de sua constituição.

Art. $6^{\circ}$ - A sentença que extinguir a união civil conterá a partilha dos bens dos interessados, de acordo com o disposto no instrumento público.

Art. $7^{\circ}-\mathrm{O}$ registro de constituição ou extinção da união civil será averbado nos assentos de nascimento e casamento das partes.

Art. $8^{\circ}$ É crime, de ação penal pública condicionada à representação, manter o contrato de união civil a que se refere esta lei com mais de uma pessoa, ou infringir o $\S 2^{\circ}$ do art. $2^{\circ}$

Pena - detenção de 6 (seis) meses a 2 (dois) anos.

Art. $9^{\circ}$ - Alteram-se os artigos da Lei 6.015, de 31 de dezembro de 1973, que passam a vigorar com as seguintes redações:

"Art. 33 - Haverá em cada cartório os seguintes livros, todos com trezentas folhas cada um:

(...)

III - B - Auxiliar - de registro de casamento religioso para efeitos civis e contratos de união civil entre pessoas do mesmo sexo.

Art. 167 - No Registro de Imóveis, além da matrícula, serão feitos:

I - o registro:

(...)

35 - dos contratos de união civil entre pessoas do mesmo sexo que versarem sobre comunicação patrimonial, nos registros referentes a imóveis ou a direitos reais pertencentes a qualquer das partes, inclusive os adquiridos posteriormente à celebração do contrato.

II - a averbação:

(...)

14 - das sentenças de separação judicial, de divórcio, de nulidade ou anulação do casamento e de extinção de união civil entre pessoas do mesmo sexo, quando nas respectivas partilhas existirem imóveis ou direitos reais sujeitos a registro." 
Art. 10 - O bem imóvel próprio e comum dos contratantes de união civil com pessoa do mesmo sexo é impenhorável, nos termos e condições regulados pela Lei 8.009, de 29 de março de 1990.

Art. 11 - Os artigos 16 e 17 da Lei 8.213, de 24 de julho de 1991, passam a vigorar com a seguinte redação:

"Art. $16(\ldots)$

$\S 3^{\circ}$. Considera-se companheiro ou companheira a pessoa que, sem ser casada, mantém com o segurado ou com a segurada, união estável de acordo com o parágrafo $3^{\circ}$ do art. 226 da Constituição Federal, ou união civil com pessoa do mesmo sexo nos termos da lei.

Art. 17 (...)

$\S 2^{\circ}$. O cancelamento da inscrição do cônjuge e do companheiro ou companheira do mesmo sexo se processa em face de separação judicial ou divórcio sem direito a alimentos, certidão de anulação de casamento, certidão de óbito ou sentença judicial, transitada em julgado".

Art. 12 - Os artigos 217 e 241 da Lei 8.112, de 11 de dezembro de 1990, passam a vigorar com a seguinte redação:

"Art. 217. (...)

c) a companheira ou companheiro designado que comprove a união estável como entidade familiar, ou união civil com pessoa do mesmo sexo, nos termos da lei.

(...)

Art. 241. (...)

Parágrafo único. Equipara-se ao cônjuge a companheira ou companheiro, que comprove a união estável como entidade familiar, ou união civil com pessoa do mesmo sexo, nos termos da lei."

Art. 13 - No âmbito da Administração Pública, os Estados, os Municípios e o Distrito Federal disciplinarão, através de legislação própria, os benefícios previdenciários de seus servidores que mantenham a união civil com pessoa do mesmo sexo.

Art. 14 - São garantidos aos contratantes de união civil entre pessoas do mesmo sexo, desde a data de sua constituição, os direitos à sucessão regulados pela Lei $n^{0} 8.971$, de 28 de novembro de 1994.

Art. 15 - Em havendo perda da capacidade civil de qualquer um dos contratantes de união civil ente pessoas do mesmo sexo, terá a outra parte a preferência para exercer a curatela. 
Art. 16 - O inciso I do art. 113 da Lei 6.815, de 19 de agosto de 1980 passa a vigorar com a seguinte redação:

"Art. 113. (...)

I - ter filho, cônjuge, companheira ou companheiro de união civil ente pessoas do mesmo sexo, brasileiro ou brasileira".

Art. 17 - Esta Lei entra em vigor na data de sua publicação.

Art. 18 - Revogam-se as disposições em contrário.

Sala das Sessões, em 26 de outubro de 1995

Deputada Marta Suplicy

SUBSTITUTIVO ADOTADO PELA COMISSÃO DO PROJETO DE LEI No 1.151 , DE 1995

Disciplina a parceria civil registrada entre pessoas do mesmo sexo e dá outras providências.

O Congresso Nacional decreta:

Art. $1^{\circ}$ - É assegurado a duas pessoas do mesmo sexo o reconhecimento de sua parceria civil registrada, visando a proteção dos direitos à propriedade, à sucessão e dos demais assegurados nesta Lei.

Art. $2^{\circ}$ - A parceria civil registrada entre pessoas do mesmo sexo constitui-se mediante escritura pública e respectivo registro em livro próprio, nos Cartórios de Registro Civil de Pessoas Naturais na forma que segue:

$\S 1^{\circ}$ - Os interessados comparecerão perante os Oficiais de Registro, apresentando os seguintes documentos:

I - declaração de serem solteiros, viúvos, ou divorciados;

II - prova de capacidade civil absoluta, mediante apresentação de certidão de idade ou prova equivalente;

III - instrumento público de contrato de parceria civil.

$\S 2^{\circ}$ - Após a lavratura do contrato a parceria civil deve ser registrada em livro próprio no Registro Civil de Pessoas Naturais.

$\S 3^{\circ}$ - O estado civil dos contratantes não poderá ser alterado na vigência do contrato de parceria civil registrada. 
Art. $3^{\circ}$ - O contrato de parceria civil será lavrado em Ofício de Notas, sendo livremente pactuado e versando sobre disposições patrimoniais, deveres, impedimentos e obrigações mútuas.

$\S 1^{\circ}$ - Somente por disposição expressa no contrato, as regras nele estabelecidas também serão aplicadas retroativamente, caso tenha havido concorrência para formação do patrimônio comum.

Art. $4^{\circ}$ - A extinção da parceria civil ocorrerá:

I - pela morte de um dos contratantes;

II - mediante decretação judicial.

III - de forma consensual, homologada pelo juiz.

Art. $5^{\circ}$ - Qualquer das partes poderá requerer a extinção da parceria civil registrada:

I - demonstrando a infração contratual em que se fundamenta o pedido;

II - alegando desinteresse na sua continuidade.

Art. $6^{\circ}$ - A sentença que homologar ou decretar a extinção da parceria civil registrada conterá a partilha dos bens dos interessados, de acordo com o disposto no instrumento público.

Art. $7^{\circ}$ - É nulo de pleno direito o contrato de parceria civil registrada feito com mais de uma pessoa, ou quando houver infração ao $\S 2^{\circ}$ do art. $2^{\circ}$ desta Lei.

Parágrafo único - Ocorrendo a infração mencionada no caput, seu autor comete o crime de falsidade ideológica, sujeitando-se às penas do art. 299 do Decreto-Lei $\mathrm{n}^{\circ}$ 2848, de 7 de dezembro de 1940.

Art. $8^{\circ}$ - Alteram-se os artigos 29, 33 e 167, da Lei 6.015, de 31 de dezembro de 1973, que passam a vigorar com as seguintes redações:

“Art. 29 - Serão registrados no registro civil de pessoas naturais:

(...)

IX - os contratos de parceria civil registrada entre pessoas do mesmo sexo.

$\S 1^{\mathrm{o}}$ - Serão averbados:

(...)

g) a sentença que homologar ou decretar a extinção da parceria civil registrada entre pessoas do mesmo sexo.

Art. 33 - Haverá em cada cartório os seguintes livros:

(...)

VII - E - de registro de contratos de parceria civil registrada entre pessoas do mesmo sexo. 
Art. 167 - No Registro de Imóveis, além da matrícula, serão feitos:

I - o registro:

(...)

35 - dos contratos de parceria civil registrada entre pessoas do mesmo sexo que versarem sobre comunicação patrimonial, nos registros referentes a imóveis ou a direitos reais pertencentes a qualquer das partes, inclusive os adquiridos posteriormente à celebração do contrato.

II - a averbação:

$(\ldots)$

14 - das sentenças de separação judicial, de divórcio, de nulidade ou anulação do casamento e de extinção de parceria civil registrada entre pessoas do mesmo sexo, quando nas respectivas partilhas existirem imóveis ou direitos reais sujeitos a registro."

Art. $9^{\circ}$ - O bem imóvel próprio e comum dos contratantes de parceria civil registrada entre pessoas do mesmo sexo é impenhorável, nos termos e condições regulados pela Lei 8.009, de 29 de março de 1990.

Art. 10 - Registrado o contrato de parceria civil de que trata essa Lei, o parceiro será considerado beneficiário do Regime Geral de Previdência Social, na condição de dependente do segurado.

Parágrafo único. A extinção do contrato de parceria civil implica o cancelamento da inscrição a que se refere o caput deste artigo.

Art. 11 - O parceiro que comprove a parceria civil registrada será considerado beneficiáro da pensão prevista no art. 217 , I, da Lei $\mathrm{n}^{\circ} 8112$, de 11 de dezembro de 1990.

Art. 12 - No âmbito da Administração Pública, os Estados, os Municípios e o Distrito Federal disciplinarão, através de legislação própria, os benefícios previdenciários de seus servidores que mantenham parceria civil registrada com pessoa do mesmo sexo. Art. 13 - São garantidos aos contratantes de parceria civil registrada entre pessoas do mesmo sexo, desde a data de sua constituição, os direitos à sucessão, nas seguintes condições:

I - o parceiro sobrevivente terá direito, enquanto não contratar nova parceria civil registrada, ao usufruto da metade dos bens do de cujus, se houver filhos deste; 
II - o parceiro sobrevivente terá direitos, desde que não firme novo contrato de parceria civil registrada, ao usufruto da quarta parte dos bens do de cujus, se não houver filhos, embora sobrevivam ascendentes;

III - na falta de descendentes e ascendentes, o parceiro sobrevivente terá direito à totalidade da herança;

IV - se os bens deixados pelo autor da herança resultarem de atividade em que haja colaboração do parceiro, terá o sobrevivente direito à metade dos bens.

Art. 14 - O art. 454, da Lei 3071 , de $1^{\circ}$ de janeiro de 1916, passa a vigorar acrescido do $\S 3^{\circ}$, com a redação que se segue, passando o atual $\S 3^{\circ}$ a $\S 4^{\circ}$ :

“Art. $454 \ldots$

(...)

$\S 3^{\circ}$ - Havendo parceria civil registrada com pessoa do mesmo sexo, a esta se dará a curatela.".

Art. 15 - O art. 113 da Lei 6815, de agosto de 1980, passa a vigorar com a seguinte redação:

“Art. $113 \ldots$

(...)

VI - ter contrato de parceria civil registrada com pessoa de nacionalidade brasileira.".

Art. 16 - É reconhecido aos parceiros o direito de composição de rendas para aquisição da casa própria e todos os direitos relativos a planos de saúde e seguro de grupo.

Art. 17 - Será admitido aos parceiros a inscrição como dependentes para efeitos de legislação tributária.

Art. 18 - Esta Lei entra em vigor na data de sua publicação.

Art. 19 - Revogam-se as disposições em contrário.

Sala da Comissão, em 10 de dezembro de 1996

Deputada Maria Elvira - Presidenta

Deputado Roberto Jefferson - Relator 
PROJETO DE LEI N. 580, DE 2007

do Deputado Federal Clodovil Hernandes

Altera a Lei 10.406, de 10 de janeiro de 2002 - Código Civil, para dispor sobre o contrato civil de união homoafetiva.

O Congresso Nacional decreta:

Art. 1. ${ }^{\circ}$ Esta Lei altera a Lei 10.406, de 10 de janeiro de 2002, para dispor sobre o contrato de união homoafetiva.

Art. 2. ${ }^{\circ}$ Acrescente à Lei 10.406 , de 10 de janeiro de 2002, o seguinte capítulo e respectivo artigo:

\section{Capitulo XVIII-A}

Do contrato de união homoafetiva

Art. 839-A. Duas pessoas do mesmo sexo poderão constituir união homoafetiva por meio de contrato em que disponham sobre suas relações patrimoniais.

Parágrafo único. É assegurado, no juízo cível, o segredo de justiça em processos relativos a cláusulas do contrato de união homoafetiva.

Art. 4. ${ }^{\circ}$ Acrescente ao art. 1790 da Lei 10.406, de 10 de janeiro de 2002, o seguinte parágrafo:

Parágrafo único. As disposições desse artigo, aplica-se, no que couber, aos companheiros homossexuais.

Art. 5. ${ }^{\circ}$ Esta lei entra em vigor na data de sua publicação.

\section{JUSTIFICAÇÃO}

Por outro lado, seguindo uma tendência mundial de tolerância em relação as diferenças, procura-se com esse projeto atender reivindicação dos grupos homossexuais com vistas a integrá-los no ordenamento jurídico e caminhar para a eliminação de preconceitos em razão da orientação sexual. Esse projeto tem como antecedente minuta elaborada pelos notáveis familiaristas e professores: Fernando Malheiros F. ${ }^{\circ}$ (RS), Paulo Lins e Silva (RJ), Roberto Rodrigues Alves (DF), Segismundo Gontijo (JG) e Sérgio Marques da Cruz (SP), a pedido da então Deputada Laura Carneiro, quando Presidente da Comissão de Família e Seguridade 
Social, para apresentar o Projeto de Lei 309/2007, que foi arquivado na legislatura anterior. Com a publicação da Lei 10.406, de 10 de janeiro de 2002 - Código Civil, as sugestões relativas à união perderam quase que totalmente a oportunidade, com exceção do dispositivo que está sendo apresentado com o objetivo de atender ao comando constitucional. Porém, a parte relativa à união civil homoafetiva continua na agenda política. Essas são as razões pelo qual conclamo meus Pares a votar pela aprovação desse projeto. Sala das Sessões, em de de 2007. Deputado Clodovil Hernandes

APÊNDICE 1-I: PROJETO DE LEI N`, DE 2006 (ARQUIVADO) da Deputada Laura Carneiro

Altera a Lei 10.406, de 10 de janeiro de 2002 - Código Civil, para dispor sobre o contrato civil de união homoafetiva.

O Congresso Nacional decreta:

Art. 1. ${ }^{\circ}$ Esta Lei altera a Lei 10.406, de 10 de janeiro de 2002, para dispor sobre o contrato de união homoafetiva.

Art. 2. ${ }^{\circ}$ Acrescente à Lei 10.406 , de 10 de janeiro de 2002, o seguinte capítulo e respectivo artigo.

Capitulo XVIII-A

Do contrato de união homoafetiva

Art. 839-A. Duas pessoas do mesmo sexo poderão constituir união homoafetiva por meio de contrato em que disponham sobre suas relações patrimoniais.

Parágrafo único. É assegurado, no juízo cível, o segredo de justiça em processos relativos a cláusulas do contrato de união homoafetiva.

Art. 3. ${ }^{\circ}$ Acrescente ao art. 1790 da Lei 10.406, de 10 de janeiro de 2002, o seguinte parágrafo:

Parágrafo único. As disposições desse artigo, aplicam-se, no que couber, aos companheiros homossexuais.

Art. 4. ${ }^{\circ}$ Esta lei entra em vigor na data de sua publicação. 
Seguindo uma tendência mundial de tolerância em relação as diferenças, procura-se com esse projeto atender reivindicação dos grupos homossexuais com vistas a integrá-los no ordenamento jurídico e caminhar para a eliminação de preconceitos em razão da orientação sexual. Esse projeto tem como antecendente minuta elaborada pelos notáveis familiaristas e professores: Fernando Malheiros F. ${ }^{\circ}$ (RS), Paulo Lins e Silva (RJ), Roberto Rodrigues Alves (DF), Segismundo Gontijo (JG) e Sérgio Marques da Cruz (SP), a nosso pedido, quando Presidente da Comissão de Família e Seguridade Social, para apresentar substitutivo a outros projetos em tramitação na Casa. Reconhecer aos homossexuais a aplicação do princípio da dignidade humana e da proibição de qualquer forma de preconceito é a razão pelo qual conclamo meus Pares a votar pela aprovação desse projeto. Sala das Sessões, em de de 2006. Deputada Laura Carneiro

\section{APÊNDICE 1-II: COMISSÃO DE SEGURIDADE SOCIAL E FAMÍLIA} PROJETO DE LEI No 580, DE 2007

Altera a Lei 10.406, de 10 de janeiro de 2002 - Código Civil, para dispor sobre o contrato civil de união homoafetiva.

Autor: Deputado CLODOVIL HERNANDES

Relator: Deputado MAURÍCIO TRINDADE

\section{I - RELATÓRIO}

Pela presente proposta, o Deputado Clodovil Hernandes pretende acrescentar ao Código Civil uma espécie de contrato entre parceiros homossexuais dispondo sobre suas relações patrimoniais e o segredo de justiça no Juízo Cível nas demandas que envolvam esse tipo de contrato. Alega na defesa de sua Proposição que: "Por outro lado, seguindo uma tendência mundial de tolerância em relação as diferenças, procura-se com esse projeto atender reivindicação dos grupos homossexuais com vistas a integrá-los no ordenamento jurídico e caminhar para a eliminação de preconceitos em razão da orientação sexual...”. A esta Comissão de Seguridade Social e Família compete analisar o mérito da proposta, sendo a apreciação conclusiva (art. 24, II do Regimento Interno). No prazo, não foram apresentadas emendas. É o Relatório. 
A Proposição, a nosso ver, não se apresenta oportuna. Embora as relações patrimoniais entre pessoas do mesmo sexo sejam cada vez mais comuns e as relações homossexuais sejam aceitas há algum tempo, os companheiros ou companheiras não podem constituir família, no tradicional e exato termo em que ser assenta nossa sociedade. Um contrato para fins patrimoniais, de união civil ou de sociedade de fato, por não estar vedado pela Constituição Federal ou pela lei infraconstitucional, pode ser perfeitamente pactuado entre quem quer que seja sem que haja necessidade de alteração da legislação em vigor. Princípio basilar na interpretação da lei é aquele que reza: o que não está proibido pela norma legal, pode ser realizado por qualquer um, independentemente de sexo, raça, credo, etc. As relações patrimoniais entre pessoas do mesmo sexo ou não que vivam em união podem ser livremente pactuadas pelos interessados. Deste modo a Proposição sob comento não pode ser acolhida. Nosso voto é, portanto, pela rejeição do Projeto de Lei $n^{\circ} 580$, de 2007. Sala da Comissão, em de de 2008. Deputado Maurício Trindade. Relator 
PROJETO DE LEI N. ${ }^{\circ}$ 674, DE 2007

do Deputado Federal Cândido Vaccarezza

Regulamenta o artigo $226 \S 3^{\circ}$ da Constituição Federal, união estável, institui o divórcio de fato.

O Congresso Nacional decreta:

DA UNIÃO ESTAVEL

Art. $1^{\circ}$ - É reconhecida como entidade familiar a união estável, pública, continua e duradoura, entre duas pessoas capazes, estabelecida com o objetivo de constituição familiar.

Parágrafo único Não será reconhecida como entidade familiar a união estável constituída por companheiro que mantenha simultaneamente casamento ou união estável reconhecida formalmente, com terceiro (a).

DO ESTADO CIVIL

Art. $2^{\circ} \mathrm{O}$ Estado civil das pessoas em união estável é o de Consorte.

Parágrafo Único- Companheiros e consortes são denominações para identificar os sujeitos da união estável, podendo os termos serem utilizados indistintamente.

Art. $3^{\circ}$-São direitos e deveres iguais dos consortes :

I- respeito, lealdade e consideração mútuos;

II- Assistência moral e material recíproca;

III- Guarda, sustento e educação dos filhos comuns.

Art.4 $4^{\circ}$ - Os consortes poderão, de comum acordo e a qualquer tempo, requerer a conversão da união estável em casamento, por requerimento ao Oficial do Registro Civil da circunscrição de seu domicilio.

DA PROVA DA UNIÃO

Art. $5^{\circ}$. São instrumentos hábeis comprobatórios do estado civil de consorte:

I- Escritura pública de declaração de união estável;

II- Declaração conjunta de Imposto de Renda;

III- Declaração judicial;

IV- Outros meios idôneos de prova. 
Parágrafo Único- A existência única de um dos itens do presente artigo é suficiente para o reconhecimento do estado civil de consorte.

\section{DA DISSOLUÇÃO DA UNIÃO ESTÁVEL}

Art.6 $6^{\circ}$ A união estável é extinta:

I- Pela livre e espontânea vontade dos companheiros;

II- Pela morte de um dos consortes;

III- Pelo divórcio de fato;

IV- Pela sentença judicial.

\section{DO DIVORCIO DE FATO}

Art. $8^{\circ}$ - O Divórcio de fato consiste na ruptura, por mais de cinco anos, da vida em comum dos integrantes de relação conjugal ou de união estável.

Art.9 - O Divórcio de fato:

I- extingue de pleno direito a sociedade familiar;

II- dissolve o casamento;

III- dissolve a união estável.

IV- põe termo aos deveres de coabitação, de fidelidade recíproca e ao regime de bens;

V- não modifica o direito e deveres dos pais em relação aos filhos;

VI- não extingue o direito de alimentos

\section{DOS ALIMENTOS}

Art. 10- Dissolvida a união estável são devidos os alimentos ao consorte que dele necessitar.

Parágrafo único: A obrigação de prestar alimentos transmite-se aos herdeiros do devedor.

\section{DO PARENTESCO}

Art.11- Cada consorte é aliado aos parentes do outro pelo vinculo da afinidade $\S 1^{\circ}$ - o parentesco por afinidade limita-se aos ascendentes, aos descendentes e aos irmãos do consorte

$\S 2^{\circ}$ - na linha reta, a afinidade não se extingue com a dissolução da união estável.

\section{DO REGIME DE BENS}

Art.12- Os bens móveis e imóveis adquiridos por um ou por ambos os companheiros, na constância da união estável e a titulo oneroso, são considerados fruto do trabalho e 
da colaboração comum, passando a pertencer a ambos, em condomínio e em partes iguais, salvo estipulação contrária em contrato escrito.

Parágrafo único- Não se aplica o caput deste artigo em relação aos móveis e imóveis adquiridos exclusivamente através do produto de bens pertencente aos companheiros anteriormente a união; caso em que a propriedade será definida na mesma proporção da participação patrimonial de cada um dos consortes.

Art. 13- As benfeitorias realizadas em bens particulares de cada companheiro, só serão comunicáveis se o bem principal também o for.

Art. 14- Os bens adquiridos anteriormente a união estável e os indicados no art.1659 e 1661 do Código Civil ( lei....)não são comunicáveis.

Art. 15- A administração do patrimônio comum dos consortes compete a ambos, salvo estipulação contrária em contrato escrito.

\section{DO DIREITO SUCESSÓRIO}

Art.16- Dissolvida a união estável por morte de um dos consortes o sobrevivente participará da sucessão do companheiro como herdeiro necessário .

$\S 1^{\circ}$ - Para efeito de direitos sucessórios o consorte é equiparado, no que couber, a figura do cônjuge.

Art.17- O consorte sobrevivente terá direito, enquanto não constituir nova união, ao usufruto do imóvel destinado à residência da família.

Art. 18- Toda a matéria relativa a união estável é de competência do juízo da Vara da Família assegurado o segredo de justiça.

\section{DISPOSIÇÕES FINAIS}

Art.19- O caput do art.1723 da Lei 10.406, de 10 de janeiro de 2002, passa a ter a seguinte redação:

“Art.1723- É reconhecida como entidade familiar a união estável, pública, continua e duradoura, entre duas pessoas capazes,estabelecida com o objetivo de constituição familiar".

Art.20- Acrescente-se ao art.1571 da Lei 10.406, de 10 de janeiro de 2002, inciso V com a seguinte redação:

"Art. 1571-...

$\cdots$

V - pelo divórcio de fato."

Art. 21- Esta lei entra em vigor na data da sua publicação 
Art. 22- Revoga-se a Lei n. ${ }^{\circ} 9.278$ de 10 de maio de 1996, e a Lei n' 8.971 , de 29 de dezembro de 1994.

\section{JUSTIFICATIVA}

A constituição de 1988 em seu artigo 226 §3º acolheu a união estável como uma figura jurídica representativa da família. Em decorrência deste primeiro reconhecimento surgiram dois novos diplomas legais, a Lei 8971/94 e a Lei 9278/96. Em 2003 o Código Civil introduziu no Livro IV- Do Direito de Família o Título IIIDa União Estável, sepultando o tratamento original dado a estas relações, ligado ao Direito das Obrigações, e consolidando a união estável como unidade familiar. Apesar deste reconhecimento constitucional e infraconstitucional, muitas lacunas jurídicas continuam a existir, além de interpretações conflitantes sobre preceitos normatizados. A primeira lacuna preenchida pelo projeto consiste na definição do estado civil daqueles que vivem em união estável; o projeto em seu art. $2^{\circ}$ estabelece o estado civil de Consorte. Procuramos também responder uma demanda da sociedade referente à crescente união envolvendo sujeitos que são casados juridicamente, mas estão separados de fato há anos de seus conjugues e vem a estabelecer nova união com terceira pessoa. As questões patrimoniais e sucessórias envolvidas em casos como estes não são simples e, muitas vezes, por falta de previsão legal, o Judiciário é forçado a reconhecer a segunda relação como concubinato, embasado em fundamentos formais, distanciando-se da verdadeira justiça. O divorcio de fato, conceito jurídico novo introduzido neste projeto, objetiva amparar o judiciário para responder a situações como esta. A necessidade do lapso temporal de cinco anos para constituição do Divorcio de fato se deve ao respeito e harmonização com o disposto no art.1642, inc. V do Código Civil- onde é autorizado ao cônjuge, de casal separado de fato há mais de cinco anos, a reivindicar os bens comuns doados ou transferidos pelo outro cônjuge ao concubino. E o cuidado de não suplantar, com uma figura jurídica mais informal, a separação e o divorcio judicial. A falta de sistematização e harmonização dos conceitos regulados pelas Leis $n^{\circ}{ }^{\circ}$ 9.278/96 e $\mathrm{n}^{\circ}$ 8.971/94 resulta em uma crescente utilização do judiciário para o reconhecimento da união estável, de sua característica como entidade familiar, e definição de direitos patrimoniais e sucessórios decorrentes. Fizemos um diagnóstico da legislação em vigor e reproduzimos neste projeto os conceitos que se harmonizam com as reivindicações sociais atuais sobre este tema. A resistência no 
reconhecimento de unidades familiares constituídas por relações homoafetivas é justificada, por muitos, com o argumento jurídico de que a legislação utilizou os termos "homem" e "mulher" para definir os sujeitos da relação. Demos nova redação ao conceito de união estável, mantendo a exigência da publicidade, estabilidade e objetivo de constituição familiar, mas definimos os sujeitos da relação como "pessoas capazes", englobando as relações entre homossexuais e heterossexuais. A Lei 9278/96 ao determinar a revogação "das leis em contrário" sem especificar a revogação da Lei 8971/94, que determinava para o reconhecimento da relação a necessidade de convivência pelo período especifico de cinco anos, criou a celeuma jurídica referente a necessidade ou não de lapso temporal de 5 anos para o reconhecimento da união estável. A dispensa do lapso temporal é reconhecida por grande parte da doutrina e jurisprudência, mas não impede julgados desfavoráveis exigindo o prazo de cinco anos e nem mesmo a construção legislativa; a Lei Estadual nº7672/82, do Estado do Rio Grande do Sul, exige, para concessão do beneficio de pensão por morte à companheira (o), comprovação de convivência "more uxório" de mais de cinco anos.

Tivemos o cuidado de inserir no projeto todos os conceitos determinados nas leis anteriores, mas a revogamos expressamente para que não paire dúvidas sobre a aplicação dos dispositivos. Objetivamos com a aprovação do projeto colaborar na harmonização e definição dos conceitos envolvendo esta "nova" instituição familiar e dar respaldo jurídico a relações afetivas consolidadas, que já venceram tabus sociais, mas ainda enfrentam resistências institucionais. Sala das sessões em, Deputado Federal Cândido Vaccarezza

\section{APÊNDICE 2-I: COMISSÃO DE SEGURIDADE SOCIAL E FAMÍLIA}

PROJETO DE LEI No 674, DE 2007

Regulamenta o Art. 226, $\S 3^{\circ}$, da Constituição Federal, união estável, institui o divórcio direto.

Autor: Deputado CÂNDIDO VACCAREZZA

Relator: Deputado JOSÉ LINHARES

\section{I - RELATÓRIO}

Trata-se de Projeto de Lei de autoria do Senhor Deputado Federal Cândido Vaccarezza (PT-SP), propondo a regulamentação do artigo 226, § $3^{\circ}$, da Constituição 
Federal, que dispõe sobre o reconhecimento da união estável entre o homem e a mulher como entidade familiar. O projeto propõe o reconhecimento da união estável não somente entre o homem e a mulher, mas entre duas pessoas capazes, independentemente de serem homens e mulheres. Ou seja, propõe que o Estado reconheça como entidade familiar a união estável de homem com mulher, de homem com homem ou de mulher com mulher. Além disso, propõe a criação de uma figura jurídica nova denominada de "divórcio de fato" para dissolver a união estável, cuja ruptura persistir por mais de cinco anos. Em seus 22 (vinte e dois) artigos, o projeto dispõe sobre a definição de união estável, sobre o estado civil das pessoas em união estável, sobre a prova da união estável, sobre a dissolução da união estável, sobre o divórcio de fato, sobre os alimentos que podem ser requeridos na união estável, sobre o parentesco entre as pessoas que assim vivem, sobre o regime de bens e sobre o direito sucessório na união estável. Propõe, ainda, a revogação da Lei $n^{\circ}$ 9.278, de 10 de maio de 1996, e da Lei no 8.971, de 29 de dezembro de 1994, que tratam da união estável. No prazo regimentalmente previsto foi apresentada uma Emenda, de autoria do Deputado Antônio Bulhões. Sua intenção é reafirmar que entidade familiar é a união estável, pública, contínua e duradoura entre homem e mulher. Em apenso há o Projeto de Lei 1149/2007, do Deputado Maurício Trindade, que acresce parágrafo único ao Art. 1723, da lei 10.406, de 10 de janeiro de 2002 - Código Civil, para prever que da união estável se faria prova plena tão só com a escritura pública lavrada na qual os companheiros declaram sua existência. A justificativa faz notar que tal norma seria necessária porque é preciso desburocratizar a prova da união estável, para combater as excessivas exigências de órgãos da administração pública e entidades privadas para reconhecer sua existência. É o Relatório.

\section{II - VOTO DO RELATOR}

Cabe a esta Comissão a análise do mérito dos Projetos e sob a óptica da família as proposições não merecem prosperar, pois é flagrantemente inconstitucional ao propor a modificação do art. 226, $\S 3^{\circ}$, da Constituição Federal de 1988, através de Lei Complementar. Embora a Constituição Federal tenha determinado que a lei facilitaria a conversão da união estável em casamento, jamais foi intenção do Constituinte equipará-la ao instituto do casamento. Veja que o projeto propõe o reconhecimento da união estável entre duas pessoas capazes, não fazendo qualquer distinção entre o homem e a mulher, podendo então a união estável ser reconhecida entre homem que vive com homem ou entre mulher que convive com outra mulher. 
A proposição contraria o texto constitucional, porque a Constituição só reconhece a união estável entre o homem e a mulher como entidade familiar, segundo está expresso no $\S 3^{\circ}$ do art. 226 da Lei Maior. A Carta Magna não reconhece como entidade familiar a união estável existente entre mulher com mulher ou entre homem com homem. Relevante ainda é que a Constituição Federal só poderá ser modificada através de emenda constitucional ou por outra Constituição, e nunca por lei complementar. Só este fato já é o bastante para reconhecer a ilegalidade do presente projeto de lei. O projeto ainda ofende o Código Civil Brasileiro, que só reconhece, em seu artigo 1.723, como entidade familiar, a união estável entre o homem e a mulher. Ou seja, o Diploma Civil não reconhece como entidade familiar a união de homem com homem ou de mulher com mulher. As relações mantidas entre pessoas do mesmo sexo denominam-se relações homossexuais, mas não constituem união estável. Os conflitos decorrentes dessas sociedades podem ser dirimidos em juízos cíveis e não em varas de família. Vê-se, ainda, que o projeto também contraria a Declaração Universal dos Direitos do Homem porque esta também só reconhece a entidade familiar constituída por homem e mulher. No Artigo XVI diz a Declaração Universal: 1) "Os homens e mulheres maior de idade, sem qualquer restrição de raça, nacionalidade ou religião, têm o direito de contrair matrimônio e fundar uma família. Gozam de iguais direitos em relação ao casamento, sua duração e sua dissolução". Se por um lado a união estável é tão comum em nossa sociedade que mereça reconhecimento e proteção legal, por outro lado a criação de um Estatuto próprio, com regras amplas e cada vez maior facilidade de comprovação, acabaria por desestimular o casamento, justamente ao contrário da determinação constitucional. A regulamentação da união estável deve ser mínima, permanecendo como é hoje, senão estaremos prejudicando o instituto do casamento, que é a base da família e da sociedade. Também não se pode acolher a proposição por ser contrária à família brasileira, uma vez que as relações homeoafetivas não devem ser equiparadas às uniões entre homem e mulher. Somente a estas, que são as uniões naturais e consentâneas com a moral e tradição da sociedade brasileira, é que a lei de família deve regular. Não vemos também qualquer benefício no chamado divórcio de fato. $\mathrm{O}$ divórcio já existe há 30 anos em nossa legislação e não precisa ser trazido ao campo da união estável. Não deve haver alargamento de suas hipóteses, que devem permanecer aquelas elencadas na Constituição Federal. Mais uma vez, não há necessidade e traz insegurança social a supressão das formalidades da legislação 
atual, que já são mínimas. Acreditamos que não seja necessária a Emenda apresentada ao Projeto, em vista que, já é especificada pelo nosso Código Civil, a união estável entre o homem e a mulher, assim como na Constituição Federal. Desse modo, rejeitamos a Emenda do Deputado Antônio Bulhões. Por último, julgamos ser desnecessária a norma da proposição em apenso, pelos motivos supra elencados, não seja benéfico trazer ainda mais facilidades para a união estável. Diante do exposto, o nosso voto é pela rejeição do Projeto de Lei n 674, de 2007, bem como ao Projeto de Lei $n^{\circ} 1.149$, de 2007, apensado. Sala da Comissão, em de de 2007. Deputado JOSÉ LINHARES Relator

\section{APÊNDICE 2-II: COMISSÃO DE SEGURIDADE SOCIAL E FAMÍLIA}

PROJETO DE LEI N. 674, DE 2007

Regulamenta o artigo 226, $\S 3^{\circ}$ da Constituição Federal, união estável, institui o divórcio direto.

Autor: Deputado Cândido Vaccareza.

Relator: Deputado José Linhares.

VOTO EM SEPARADO DO DEPUTADO PEPE VARGAS

\section{I - RELATÓRIO}

O Projeto de Lei em destaque institui o divórcio de fato, estabelece o estado civil das pessoas em união estável como o de Consorte, altera a Lei no 10.406, de 2002 (Novo Código Civil) e revoga as Leis ${ }^{\circ}$ s 8.971, de 1994 e 9.278, de 1996.

A proposição é sujeita à apreciação conclusiva pelas comissões, sendo distribuído às Comissões de Seguridade Social e Família e à Comissão de Constituição e Justiça e Cidadania. No âmbito da Comissão de Seguridade Social e Família, competente para analisar o mérito da matéria, foi designado o Deputado José Linhares como relator. Em seu parecer o nobre parlamentar rejeita o Projeto de Lei 674/2007, bem como o PL 1.149, de 2007, apensado. É o relatório.

II - VOTO

Ora, diferentemente do que assevera o nobre Deputado Relator, entendemos que a aprovação do vertente projeto tem o mérito de colaborar para a harmonização e definição dos conceitos envolvendo a instituição familiar, além de dar respaldo jurídico às relações afetivas consolidadas, que já venceram tabus sociais. Desse modo, refutamos a argumentação de que o Projeto de Lei tem vício de 
constitucionalidade, por ter sido proposta a modificação do art. $226, \S 3^{\circ}$, da Constituição Federal através de Lei Complementar. Na realidade, a intenção não é modificar o referido artigo e sim regulamentar e preencher lacunas existentes no ordenamento jurídico quanto ao reconhecimento da união estável como entidade familiar, conforme o constituinte originário previu: "Para efeito da proteção do Estado, é reconhecida a união estável entre o homem e a mulher como entidade familiar, devendo a lei facilitar sua conversão em casamento". Equivoca-se o relator ainda quando diz que a matéria foi proposta por Projeto de Lei Complementar. $\mathrm{Na}$ verdade, trata-se na realidade de projeto de lei, haja vista que as matérias objeto de lei complementar estão taxativamente definidas na Constituição Federal, o que não ocorre na espécie. Porém, a Carta Magna reserva a regulamentação do reconhecimento da união estável como entidade familiar através de lei, procedimento devidamente adotado quando da apresentação da matéria através de projeto de lei, não padecendo, assim, o PL 674/2007 de inconstitucionalidade. É verdade que a Constituição Federal só poderá ser modificada através de emenda constitucional ou por outra Constituição, mas no caso em tela, conforme já mencionado, não se trata de modificação, mas sim de regulamentação da matéria. Quando o nobre relator afirma que a proposição contraria o texto constitucional, porque a constituição só reconhece a união estável entre o homem e a mulher como entidade familiar, comete um deslize quanto à interpretação da letra da lei. A Constituição Federal na realidade não exclui, expressamente, a proteção das relações homoafetivas, apenas omitindo a regulamentação, o que evidencia o pensamento Kelsiano "tudo o que não está expressamente proibido, está, implicitamente permitido", abrindo uma lacuna para interpretação analógica do artigo, devendo seguir a hermenêutica de um sistema de normas e princípios constitucionais fundamentais. No reconhecimento da união estável como entidade familiar não se deve excluir tais princípios Nesse sentido, a Constituição Federal consagra como fundamento do Estado Democrático do Direito a dignidade da pessoa humana; como objetivo, a construção de uma sociedade livre, justa e solidária, sem preconceitos de sexo e de quaisquer formas de discriminação; e como princípios fundamentais os direitos de liberdade e igualdade. Portanto, as pessoas sejam elas do mesmo sexo, são livres para atender a sua opção sexual, bem como a constituição de entidade familiar através de união homoafetivas, desde que se vislumbre na vida em comum os pressupostos de notoriedade, publicidade, fidelidade, e sinais explícitos de uma verdadeira comunhão de vida. Vale ressaltar 
que a Constituição Federal deve ser interpretada de acordo com a realidade social, conforme entendimento do jurista Juarez Freitas: "A Constituição Federal há de sempre ser interpretada, pois somente por meio da conjugação da letra do texto com as características históricas, políticas, ideológicas do momento, se encontrará o melhor sentido da norma jurídica, em confronto com a realidade sociopolíticoeconômico e almejando sua plena eficácia.”. É nesse quadro que os Tribunais Superiores vem decidindo que as uniões homoafetivas são reconhecidas como entidade familiar, a exemplificar: EMENTA: UNIAO HOMOSSEXUAL. RECONHECIMENTO. PARTILHA DO PATRIMONIO. MEACAO PARADIGMA. Não se permite mais o farisaísmo de desconhecer a existência de uniões entre pessoas do mesmo sexo e a produção de efeitos jurídicos derivados dessas relações homoafetivas. Embora permeadas de preconceitos, são realidades que o Judiciário não pode ignorar, mesmo em sua natural atividade retardatária. Nelas remanescem conseqüências semelhantes às que vigoram nas relações de afeto, buscando - se sempre a aplicação da analogia e dos princípios gerais do direito, relevados sempre os princípios constitucionais da dignidade humana e da igualdade. Desta forma, o patrimônio adquirido na constância do relacionamento deve ser partilhado como na união estável, paradigma supletivo onde se debruça a melhor hermenêutica. Apelação Provida, em parte, por maioria, para assegurar a divisão do acervo entre os parceiros. (Apelação Cível No 70001388982, Sétima Câmara Cível, Tribunal de Justiça do RS, Relator: José Carlos Teixeira Giorgis, Julgado em 14/03/2001); EMENTA: "É possível o processamento e o reconhecimento de união estável entre os homossexuais, ante os princípios fundamentais insculpidos na Constituição Federal que vedam qualquer discriminação, inclusive quanto ao sexo, sendo descabida discriminação quanto à união homossexual e é justamente agora, quando uma onda renovadora se estende pelo mundo, com reflexos acentuados em nosso País, destruindo preconceitos arcaicos, modificando conceitos e impondo a serenidade científica da modernidade no trato das relações humanas, que as posições devem ser marcadas e amadurecidas, para que os avanços não sofram retrocesso e para que as individualidades e as coletividades, possam andar seguras na tão almejada busca da felicidade, direito fundamental de todos. Apelação provida". (TJRS, 8 $8^{\text {a }}$ Câmara Cível, APC 598362 655. Rel. Des. José Siqueira Trindade, j. 1/03/00); EMENTA: APELAÇÃO. UNIÃO HOMOSSEXUAL. RECONHECIMENTO DE UNIÃO ESTÁVEL. PARTILHA. Embora reconhecida 
na parte dispositiva da sentença a existência de sociedade de fato, os elementos probatórios dos autos indicam a existência de união estável. PARTILHA. A união homossexual merece proteção jurídica, porquanto traz em sua essência o afeto entre dois seres humanos com o intuito relacional. Caracterizada a união estável, impõe-se a partilha igualitária dos bens adquiridos na constância da união, prescindindo da demonstração de colaboração efetiva de um dos conviventes, somente exigidos nas hipóteses de sociedade de fato. NEGARAM PROVIMENTO. (Segredo de Justiça) (Apelação Cível No 70006542377, Oitava Câmara Cível, Tribunal de Justiça do RS, Relator: Rui Portanova, Julgado em 11/09/2003); Reconhecimento da união estável homossexual pelo Tribunal Superior Eleitoral: "Ementa: REGISTRO DE CANDIDATO. CANDIDATA AO CARGO DE PREFEITO. RELAÇÃO ESTÁVEL HOMOSSEXUAL COM A PREFEITA REELEITA DO MUNICÍPIO. INELEGIBILIDADE. ART. $14, \S 7^{\circ}$, DA CONSTITUIÇÃO FEDERAL. Os sujeitos de uma relação estável homossexual, à semelhança do que ocorre com os de relação estável, de concubinato e de casamento, submetem-se à regra de inelegibilidade prevista no art. $14, \S 7^{\circ}$, da Constituição Federal. Recurso a que se dá provimento. Decisão: O Tribunal, por unanimidade, conheceu do recurso e lhe deu provimento, nos termos do voto do relator. (ACÓRDÃO 24564 VISEU - PA 01/10/2004 Relator(a) GILMAR FERREIRA MENDES Relator(a) designado(a) Publicação PSESS - Publicado em Sessão, Data 01/10/2004). E conclui da seguinte maneira: "atribuir-se tratamento diferenciado aos jurisdicionados homossexuais seria um desrespeito ao analisado princípio da igualdade. Nesse sentido, seria um absurdo aceitar que o Poder Judiciário fechasse seus olhos não só para as modificações de nossa sociedade, como para a Constituição Federal que rege nossa nação. Buscando na "falta de legislação expressa" razão suficiente para julgar injustamente fatos que ocorrem entre "minorias sociais" que já são constantemente discriminadas". Assim sendo, a vontade do legislador deve estar em consonância com a pretensão da sociedade, adaptando e regulamentando, através da realidade social que está inserida, as relações homossexuais, deixando de lado o conservadorismo, os padrões sociais ultrapassados e o preconceito. Quanto ao que se refere à criação de um Estatuto Próprio, com estabelecimento do estado civil de "Consorte" para os que vivem em união estável, com regras amplas e com maior facilidade de comprovação, ao contrário do que acredita o nobre relator, o estatuto possibilitará maior segurança jurídica na relações de união estável, vez que foram definidas as obrigações e 
responsabilidades entre os consortes, seja no que concerne nas questões patrimoniais, sucessórias, alimentos ou parentesco. Em linhas gerais: não será reconhecida a união estável na qual um dos parceiros mantiver, simultaneamente, casamento ou outra união estável; declaração de imposto de renda conjunta será considerada comprovante de união estável; os bens móveis e imóveis adquiridos por um ou por ambos os companheiros durante a união estável pertencerão aos dois consortes em partes iguais, exceto quando houver contrato definindo em contrário; encerrada a união estável por morte de um dos consortes, o sobrevivente terá os mesmos direitos de cônjuge à herança; e enquanto não constituir nova união, o consorte sobrevivente terá direito ao usufruto do imóvel destinado à residência da família. A instituição do divórcio de fato visa a simplificação do procedimento de extinção da sociedade familiar, da dissolução do casamento e da união estável, resguardado o direitos e deveres em relação aos filhos, e os direitos de alimentos. Após cinco anos de interrupção do casamento ou da união estável entre o casal ,automaticamente, fica instituído o divórcio de fato. A criação deste novo conceito jurídico facilitará a vida do cidadão, por se tratar de um procedimento simples e não oneroso. Nessa perspectiva e com vistas a estabelecer um tratamento legal da matéria mais consentâneo com o atual momento de amadurecimento social e político da população brasileira, é que apresentado o vertente Voto em Separado, cuja única finalidade é no sentido de integrar a realidade social através da regulamentação de uma nova instituição familiar, razão pela qual contamos com o apoio de nossos pares para a aprovação desse PL. Sala da Comissão, em de dezembro de 2007. PEPE VARGAS Deputado Federal - PT/RS

\section{APÊNDICE 2-III: COMISSÃO DE SEGURIDADE SOCIAL E FAMÍLIA} PROJETO DE LEI Nº 674, DE 2007

Regulamenta o art. 226, § 3, da Constituição Federal, união estável, institui o divórcio direto.

Autor: Deputado CÂNDIDO VACAREZZA

Relator: Deputado JOSÉ LINHARES

VOTO EM SEPARADO DO DEPUTADO PASTOR MANOEL FERREIRA

O Projeto de Lei, ora atacado, institui o divórcio de fato, estabelece o estado civil das pessoas, inclusive homossexuais, em união estável como o de consorte, altera a Lei 
$\mathrm{n}^{\mathrm{o}}$ 10.406, de 2002 (Novo Código Civil) e revoga as Leis $\mathrm{n}^{\circ} \mathrm{s} 8.971$, de 1994 e 9.278, de 1996. A proposição é sujeita à apreciação conclusiva pelas comissões, sendo distribuído às Comissões de Seguridade Social e Família e à Comissão de Constituição e Justiça e Cidadania.

VOTO

Não podemos concordar de nenhum modo com a proposição que ora estamos analisando. No mérito, a Proposição não merece acolhida de forma alguma. Como já disse um Deputado em outro momento, "Forças das trevas têm-se tornado mais audaciosas nos tempos que correm. A violência; a criminalidade; o afrouxamento dos valores morais e éticos; a proliferação das drogas intoxicantes; a mudança de rumos nas entidades familiares; a busca desenfreada por amealhar mais recursos econômicos, empregando-se a máxima maquiavélica de que os fins justificam os meios e por isso empregam-se todos os artifícios imagináveis e muita vez escusos; são sintomas de que a degradação humana é oriunda das forças ignorantes das trevas. Não é mais possível àqueles que têm fé em Deus, invocado como Protetor no frontispício da Constituição Federal de 1988, e na vida póstuma aceitar inermes e inertes à derrocada e destruição moral da humanidade. As doenças que têm aparecido são uma resposta dos céus para que a humanidade se recomponha e acerte o seu próprio rumo, que é a eternidade e o progresso do espírito. Nada acontece ao acaso. Olhamos o universo maravilhados perante a sua harmonia e matematicidade, o que demonstra a existência de um Ser Superior a reger sem erros toda a criação e o seu destino, e horrorizamo-nos quando vemos quererem transformar aqui na terra esta harmônica e maravilhosa obra num charco de vícios humanos. Havemos de progredir não só intelectual, mas moralmente. É o caso de estimular comportamentos antinaturais para pousar de liberal ou se é o caso de ajudar essas pessoas a encontrar o caminho de sua efetiva realização como homem ou como mulher, utilizando-se de meios científicos para corrigir as anomalias, ou ainda, se é, ou não, o caso de abrir precedentes para uma avalanche de reivindicações similares, que irão tumultuar o nosso sistema jurídico, e, mais ainda, a formação moral das novas gerações, estimulando tendências que de modo algum irão contribuir para a felicidade verdadeira dos interessados. Contraria, a proposta, os mais evidentes princípios de moral inerentes ao nosso povo, que o repudia. É infamante, pois ofensivo à dignidade da pessoa humana, princípio basilar da República. $\mathrm{O}$ amolecimento, a pusilanimidade, dos princípios éticos e morais têm levado, através da História, à 
degeneração e ao desaparecimento de povos que eram tidos como fortes. Pode-se dizer, parodiando Camões que disse "que um fraco rei fez fraca a forte gente", que um fraco projeto pode fazer fraca a forte gente de nosso País. Há ofensa à família constituída, quer de fato quer de direito. A nossa Carta Política, ao permitir que ao concubinato fosse facilitada a sua conversão em casamento, quis prestigiar o casamento entre pessoas de sexos diversos, não dando azo a que fosse institucionalizada a união homossexual, com as garantias do casamento. É claro o dispositivo constitucional, insculpido no artigo 226, $\S 3^{\circ}$, que "para efeito da proteção do Estado, é reconhecida a união estável entre homem e a mulher como entidade familiar...", qualquer alteração que refuja destes termos expressos é inconstitucional e deve ser tida como nula. E esta tal Proposta, sobre ser imoral, do nosso ponto de vista, ferindo-se os mais comezinhos princípios éticos de nossa sociedade, e também os bons costumes tão veementemente defendidos pelo novel Código Civil, está eivada de inconstitucionalidade, afronta de modo vergonhoso a Lex Fundamentalis do País. A união estável, permitida pelo art. 226, $\S 3^{\circ}$ de nossa Magna Carta, em nenhum momento pode ser tida como a união entre pessoas do mesmo sexo. Forças das trevas têm-se tornado mais audaciosas nos tempos que correm. A violência; a criminalidade; o afrouxamento dos valores morais e éticos; a proliferação das drogas intoxicantes; a mudança de rumos nas entidades familiares; a busca desenfreada por amealhar mais recursos econômicos, empregando-se a máxima maquiavélica de que os fins justificam os meios e por isso empregam-se todos os artifícios imagináveis e muita vez escusos; são sintomas de que a degradação humana é oriunda das forças ignorantes das trevas. Não é mais possível àqueles que têm fé em Deus e na vida póstuma aceitar inermes e inertes à derrocada e destruição da humanidade. As doenças que têm aparecido são uma resposta dos céus para que a humanidade se recomponha e acerte o seu próprio rumo, que é a eternidade e o progresso do espírito. Nada acontece ao acaso. Olhamos o universo maravilhados perante a sua harmonia e matematicidade, o que demonstra a existência de um Ser Superior a reger sem erros toda a criação e o seu destino, e horrorizamonos quando vemos quererem transformar, aqui na Terra, esta harmônica e maravilhosa obra num charco de vícios humanos. Havemos de progredir não só intelectual, mas moralmente. Adotar o sistema de união sexual entre pessoas do mesmo sexo, com o intuito de lhes garantir prazeres contrários aos fins da vida, que é a evolução e dignificação do espírito, é o mesmo que liberar o consumo de 
entorpecentes para que os viciados sintam o prazer da própria destruição física e moral. No Livro "gênesis", um dos pilares do Pentateuco de Moisés, este, após falar da criação por Deus do Universo, diz-nos que: "Deus disse: façamos o homem à nossa imagem e semelhança, e que ele submeta os peixes do mar, os pássaros do céu, os animais grandes, toda a terra e todos os animais pequenos que rastejam sobre a terra! Deus criou o homem à sua imagem, criou-os macho e fêmea.". Também, no Evangelho de São Matheus, Jesus Cristo, depois de ser instado pelos fariseus a respeito do que ele pensava sobre o adultério lhes disse: "Não lestes que o Criador, no princípio os fez homem e mulher e que disse: Eis por que o homem deixará seu pai e sua mãe e se ligará à mulher, e os dois se tornarão uma só carne? Assim eles não são mais dois, mas uma só carne. Não separe, pois, o homem o que Deus uniu". Alguns se levantarão e dirão, então, que não pode haver o divórcio, segundo os princípios cristãos. Entretanto basta ver, por uma análise mesmo que perfunctória que o Cristo diz que não deve o homem separar o que Deus uniu, logo o que o homem uniu por interesse ou qualquer outro motivo fútil deve ser desunido. Não iremos aqui tratar do episódio de Sodoma e Gomorra que foram castigadas por exercerem as práticas sexuais mais díspares, e por demais conhecidas, como todos têm ciência. $\mathrm{Na} 1^{\mathrm{a}}$ Epístola aos Coríntios São Paulo nos diz, no Capítulo $6^{\circ}$, versículos 9 e 10 que: "Então, não sabeis que os injustos não herdarão o Reino de Deus? Não vos enganeis a este respeito! Nem os devassos, nem os idólatras, nem os adúlteros, nem os efeminados, nem os pederastas, nem os ladrões, nem os gananciosos, nem os beberrões, nem os caluniadores, nem os rapaces herdarão o Reino de Deus.". Não que estes seres imperfeitos não poderão herdar um dia o Reino de Deus, mas que eles só o conseguirão depois de quebrarem os grilhões que os acorrentam à vida efêmera na terra, onde colocam o coração e, portanto, o seu tesouro, como o diz simbolicamente Jesus Cristo, pois tudo o que aprisiona o homem à esta é empecilho à felicidade espiritual. Como é fácil de notar, o homossexualismo não é bem-vindo para a comunidade cristã, que baseia seus princípios nos livros sagrados. A Igreja Protestante em seus mais variados segmentos é contra a prática homossexual, por atentatória dos fundamentos cristãos, e atentatória contra a própria Natureza. A Igreja Católica também se baseia nos mesmos e a repudia visceralmente. Onde, pois, encontrar argumentos para aprovar tão esdrúxula, estapafúrdia e imoral proposta, senão no que há de mais vil da condição humana: o caos moral e ético vivido pela sociedade em decadência, que diga-se "en passant", constitui-se de uma 
minoria barulhenta que em virtude disso faz-se parecer em grande número? Por todo o exposto, o nosso voto é pela inconstitucionalidade e no mérito pela rejeição dos PL $n^{\circ}$ 674, de 2007. Sala da Comissão, em de de 2008. Deputado PASTOR MANOEL FERREIRA 
PROJETO DE LEI N. 2285, DE 2007

do Dep. Sérgio Barradas Carneiro

Dispõe sobre o Estatuto das Famílias.

TÍTULO I - DAS DISPOSIÇÕES GERAIS ARTS. $1^{\circ}$ A $9^{\circ}$

TÍTULO II - DAS RELAÇÕES DE PARENTESCO ARTS. 10 A 14 TÍTULO III - DAS ENTIDADES FAMILIARES ARTS. 15 A 69 CAPÍTULO I - DAS DISPOSIÇÕES COMUNS ARTS. 15 A 20 CAPÍTULO II - DO CASAMENTO ARTS. 21 A 62 SEÇÃO I - DA CAPACIDADE PARA O CASAMENTO ART. 23 SEÇÃO II - DOS IMPEDIMENTOS ARTS. 24 A 25

SEÇÃO III - DAS PROVAS DO CASAMENTO ARTS. 26 A 27 SEÇÃO IV - DA VALIDADE DO CASAMENTO ARTS. 28 A 34 SEÇÃO V - DOS EFEITOS DO CASAMENTO ARTS. 35 A 37

SEÇÃO VI - DOS REGIMES DE BENS ARTS. 38 A 53 SUBSEÇÃO I - DISPOSIÇÕES COMUNS ARTS. 38 A 44 SUBSEÇÃO II - DO REGIME DE COMUNHÃO PARCIAL ARTS. 45 A 50 SUBSEÇÃO III - DO REGIME DA COMUNHÃO UNIVERSAL ARTS. 51 A 52

SUBSEÇÃO IV - DO REGIME DE SEPARAÇÃO DE BENS ART. 53 SEÇÃO VII - DO DIVÓRCIO E DA SEPARAÇÃO ARTS. 54 A 62 SUBSEÇÃO I - DO DIVÓRCIO ARTS. 54 A 56 SUBSEÇÃO II - DA SEPARAÇÃO ARTS. 57 A 58 SUBSEÇÃO III - DISPOSIÇÕES COMUNS AO DIVÓRCIO E À SEPARAÇÃO ARTS. 59 A 62 CAPÍTULO III - DA UNIÃO ESTÁVEL ARTS. 63 A 67 CAPÍTULO IV - DA UNIÃO HOMOAFETIVA ART. 68 CAPÍTULO V - DA FAMÍLIA PARENTAL ART. 69 TÍTULO IV - DA FILIAÇÃO ARTS. 70 A 103 CAPÍTULO I - DISPOSIÇÕES GERAIS ARTS. 70 A 77 
CAPÍTULO II - DA ADOÇÃO ARTS. 78 A 86

CAPÍTULO III - DA AUTORIDADE PARENTAL ARTS. 87 A 95

CAPÍTULO IV - DA GUARDA DOS FILHOS E DO DIREITO DE CONVIVÊNCIA ARTS. 96 A 103

TÍTULO V - DA TUTELA E DA CURATELA ARTS. 104 A 114 CAPÍTULO I - DA TUTELA ARTS. 104 A 108 CAPÍTULO II - DA CURATELA ARTS. 109 A 114 TÍTULO VI - DOS ALIMENTOS ARTS. 115 A 121 TÍTULO VII - DO PROCESSO E DO PROCEDIMENTO ARTS. 122 A 266 CAPÍTULO I - DISPOSIÇÕES GERAIS ARTS. 122 A 137 CAPÍTULO II - DO PROCEDIMENTO PARA O CASAMENTO ARTS. 138 A 163 SEÇÃO I - DA HABILITAÇÃO ARTS. 138 A 145 SEÇÃO II - DO SUPRIMENTO DE CONSENTIMENTO PARA O CASAMENTO ART. 146

SEÇÃO III - DA CELEBRAÇÃO ARTS. 147 A 152

SEÇÃO IV - DO REGISTRO DO CASAMENTO ARTS. 153 A 154 SEÇÃO V - DO REGISTRO DO CASAMENTO RELIGIOSO PARA EFEITOS CIVIS ARTS. 155 A 161 SEÇÃO VI - DO CASAMENTO EM IMINENTE RISCO DE MORTE ARTS. 162 A 163 CAPÍTULO III - DO RECONHECIMENTO DA UNIÃO ESTÁVEL E DA UNIÃO HOMOAFETIVA ARTS. 164 A 167 CAPÍTULO IV - DA DISSOLUÇÃO DA ENTIDADE FAMILIAR ARTS. 168 A 177

SEÇÃO I - DA AÇÃO DE DIVÓRCIO ARTS. 168 A 172 SEÇÃO II - DA SEPARAÇÃO ARTS. 173 A 177 CAPÍTULO V - DOS ALIMENTOS ARTS. 178 A 207 SEÇÃO I - DA AÇÃO DE ALIMENTOS ARTS. 178 A 192 SEÇÃO II - DA COBRANÇA DOS ALIMENTOS ARTS. 193 A 207

CAPÍTULO VI - DA AVERIGUAÇÃO DA FILIAÇÃO. ARTS. 208 A 210 CAPÍTULO VII - DA AÇÃO DE INVESTIGAÇÃO DE PATERNIDADE ARTS. 211 A 219 CAPÍTULO VIII - DA AÇÃO DE INTERDIÇÃO ARTS. 220 A 243 
CAPÍTULO IX - DOS PROCEDIMENTOS DOS ATOS EXTRAJUDICIAIS ARTS. 244 A 266

SEÇÃO I - DO DIVÓRCIO ARTS. 245 A 249

SEÇÃO II - DA SEPARAÇÃO ARTS. 250 A 253

SEÇÃO III - DO RECONHECIMENTO E DA DISSOLUÇÃO DA UNIÃO ESTÁVEL E HOMOAFETIVA ARTS. 254 A 258 SEÇÃO IV - DA CONVERSÃO DA UNIÃO ESTÁVEL EM CASAMENTO ARTS. 259 A 262 SEÇÃO V - DA ALTERAÇÃO DO REGIME DE BENS ARTS. 263 A 266 TÍTULO VIII - DAS DISPOSIÇÕES FINAIS E TRANSITÓRIAS ARTS. 267 A 274

O Congresso Nacional decreta:

\section{TÍTULO I}

\section{DAS DISPOSIÇÕES GERAIS}

Art. 1. ${ }^{\circ}$ Este Estatuto regula os direitos e deveres no âmbito das entidades familiares. Art. 2. ${ }^{\circ} \mathrm{O}$ direito à família é direito fundamental de todos.

Art. 3. ${ }^{\circ}$ É protegida como família toda comunhão de vida instituída com a finalidade de convivência familiar, em qualquer de suas modalidades.

Art. $4 .^{\circ}$ Os componentes da entidade familiar devem ser respeitados em sua integral dignidade pela família, pela sociedade e pelo Estado.

Art. 5. ${ }^{\circ}$ Constituem princípios fundamentais para a interpretação e aplicação deste Estatuto a dignidade da pessoa humana, a solidariedade familiar, a igualdade de gêneros, de filhos e das entidades familiares, a convivência familiar, o melhor interesse da criança e do adolescente e a afetividade.

Art. $6 .^{\circ}$ São indisponíveis os direitos das crianças, dos adolescentes e dos incapazes, bem como os direitos referentes ao estado e capacidade das pessoas.

Art. 7. ${ }^{\circ}$ É dever da sociedade e do Estado promover o respeito à diversidade de orientação sexual.

Art. $8 .^{\circ}$ A lei do país em que tiver domicílio a entidade familiar determina as regras dos direitos das famílias.

Parágrafo único. Não se aplica a lei estrangeira se esta contrariar os princípios fundamentais do direito brasileiro das famílias. 
Art. 9. ${ }^{\circ}$ Os direitos e garantias expressos nesta lei não excluem outros decorrentes do regime e dos princípios adotados na Constituição, nos tratados e convenções internacionais.

TÍTULO II

DAS RELAÇÕES DE PARENTESCO

Art. 10. O parentesco resulta da consangüinidade, da socioafetividade ou da afinidade.

Art. 11. São parentes em linha reta as pessoas que estão umas para com as outras na relação de ascendentes e descendentes.

Art. 12. São parentes em linha colateral ou transversal, até o quarto grau, as pessoas provenientes de um só tronco, sem descenderem uma da outra.

Art. 13. Contam-se, na linha reta, os graus de parentesco pelo número de gerações, e, na colateral, também pelo número delas, subindo de um dos parentes até ao ascendente comum, e descendo até encontrar o outro parente.

Art. 14. Cada cônjuge ou convivente é aliado aos parentes do outro pelo vínculo da afinidade.

$\S 1 .^{\circ} \mathrm{O}$ parentesco por afinidade limita-se aos ascendentes, aos descendentes e aos irmãos do cônjuge ou convivente.

$\S 2 .^{\circ}$ A afinidade se extingue com a dissolução do casamento ou da união estável, exceto para fins de impedimento à formação de entidade familiar.

TÍTULO III

DAS ENTIDADES FAMILIARES

CAPÍTULO I

DAS DISPOSIÇÕES COMUNS

Art. 15. É dever da entidade familiar assegurar à criança, ao adolescente e ao idoso que a integrem, com absoluta prioridade, o direito à vida, à saúde, à alimentação, à educação, ao lazer, à profissionalização, à cultura, à dignidade, ao respeito, à liberdade e à convivência familiar e comunitária, além de colocá-los a salvo de toda forma de negligência, discriminação, exploração, violência, crueldade e opressão.

Art. 16. As pessoas integrantes da entidade familiar têm o dever recíproco de assistência, amparo material e moral, sendo obrigadas a concorrer, na proporção de suas condições financeiras e econômicas, para a manutenção da família.

Art. 17. Qualquer pessoa integrante da entidade familiar tem legitimidade para defendê-la em juízo ou fora dele. 
Art. 18. A gestão dos interesses comuns da entidade familiar incumbe aos integrantes civilmente capazes, de comum acordo, tendo sempre em conta o interesse de todos os que a compõem.

Art. 19. A escolha do domicílio da entidade familiar é decisão conjunta das pessoas que a integram, observados os interesses de todo o grupamento familiar.

Parágrafo único. Admite-se a pluralidade domiciliar para as entidades familiares.

Art. 20. O planejamento familiar é de livre decisão da entidade familiar, competindo ao Estado propiciar recursos educacionais e financeiros para o exercício desse direito, vedado qualquer tipo de coerção por parte de instituições privadas ou públicas.

\section{CAPÍTULO II}

\section{DO CASAMENTO}

Art. 21. O casamento é civil e produz efeitos a partir do momento em que os nubentes manifestam a vontade de estabelecer o vínculo conjugal e a autoridade os declara casados.

Art. 22. O casamento religioso submete-se aos mesmos requisitos exigidos para o casamento civil e produz efeitos a partir da data de sua celebração.

Parágrafo único. O casamento religioso, para ter validade

e equiparar-se ao casamento civil, precisa ser levado a registro no prazo de noventa dias de sua celebração.

\section{SEÇÃO I}

\section{DA CAPACIDADE PARA O CASAMENTO}

Art. 23. Para o casamento das pessoas relativamente incapazes é necessária autorização de ambos os pais, ou de seus representantes legais.

$\S 1 .^{\circ}$ Havendo divergência entre os pais é assegurado a qualquer deles recorrer a juízo.

$\S 2 .^{\circ}$ Até a celebração do casamento os pais ou representantes legais podem revogar justificadamente a autorização.

$\S 3 .^{\circ}$ A denegação da autorização, quando injusta, pode ser suprida judicialmente.

\section{SEÇÃO II}

\section{DOS IMPEDIMENTOS}

Art. 24. Não podem casar:

I - os absolutamente incapazes;

II - os parentes na linha reta sem limitação de grau; 
III - os parentes na linha colateral até o terceiro grau, inclusive;

IV - os parentes por afinidade em linha reta;

$\mathrm{V}-$ as pessoas casadas.

Art. 25. Os impedimentos podem ser opostos, até o momento da celebração do casamento, por qualquer pessoa.

Parágrafo único. Se o celebrante, ou o oficial de registro, tiver conhecimento da existência de algum impedimento, será obrigado a declará-lo.

SEÇÃO III

\section{DAS PROVAS DO CASAMENTO}

Art. 26. O casamento prova-se pela certidão do registro civil.

$\S 1 .^{\circ}$ Justificada a falta ou perda do registro, é admissível qualquer outra prova.

$\S 2 .^{\circ} \mathrm{O}$ registro é levado a efeito no cartório do respectivo domicílio, ou, em sua falta, no cartório da cidade em que passarem a residir.

$\S 3 .^{\circ} \mathrm{Na}$ dúvida entre as provas favoráveis e contrárias, julga-se pelo casamento, se os cônjuges, cujo casamento se impugna, vivam ou viveram na posse do estado de casados.

Art. 27. Quando a prova da celebração legal do casamento resultar de processo judicial, o registro da sentença no cartório do registro civil produz efeitos desde a data do casamento.

\section{SEÇÃO IV}

\section{DA VALIDADE DO CASAMENTO}

Art. 28. É nulo o casamento contraído:

I - pela pessoa absolutamente incapaz;

II - com infringência aos impedimentos legais.

III - por procurador, se revogada a procuração antes da celebração do casamento.

Art. 29. A ação de nulidade do casamento pode ser promovida por qualquer interessado ou pelo Ministério Público.

Art. 30. É anulável o casamento:

I - dos relativamente incapazes;

II - por erro essencial quanto à pessoa do outro cônjuge, anterior ao casamento;

III - em virtude de coação;

IV - do incapaz de consentir ou manifestar, de modo inequívoco, o consentimento, no momento da celebração; 
$\mathrm{V}$ - por incompetência da autoridade celebrante, salvo se tiver havido registro do casamento.

Art. 31. O casamento do relativamente incapaz, quando não autorizado por seu representante legal, pode ser anulado em até cento e oitenta dias:

I - pelo menor, após adquirir maioridade;

II - por seus representantes legais a partir da celebração do casamento.

Art. 32. Não se anula o casamento quando os representantes legais do incapaz assistiram a celebração ou, por qualquer modo, manifestaram sua aprovação.

Art. 33. O prazo para ser intentada a ação de anulação do casamento é de cento e oitenta dias, a contar da data da celebração.

Art. 34. Embora anulável ou mesmo nulo, o casamento em relação aos cônjuges e a terceiros produz todos os efeitos até o trânsito em julgado da sentença.

Parágrafo único. A nulidade ou anulação do casamento dos pais não produz efeitos em relação aos filhos.

SEÇÃO V

DOS EFEITOS DO CASAMENTO

Art. 35. O casamento estabelece comunhão plena de vida, com base na igualdade de direitos e deveres dos cônjuges.

Art. 36. As relações pessoais entre os cônjuges devem obedecer aos deveres de lealdade, respeito e assistência, tendo ambos responsabilidade pela guarda, sustento e educação dos filhos.

Art. 37. A direção da sociedade conjugal é exercida, pelos cônjuges, em colaboração, sempre no interesse da família e dos filhos.

$\S 1 .^{\circ}$ Os cônjuges são obrigados a concorrer, na proporção de seus bens e dos rendimentos do seu trabalho, para o sustento da família e a educação dos filhos, qualquer que seja o regime de bens.

$\S 2 .^{\circ}$ Se qualquer dos cônjuges estiver impedido ou inabilitado, o outro exerce com exclusividade a direção da família, cabendo-lhe a administração dos bens.

SEÇÃO VI

DOS REGIMES DE BENS

SUBSEÇÃO I

DISPOSIÇÕES COMUNS

Art. 38. Podem os nubentes estipular, quanto aos seus bens, o que lhes aprouver. 
$\S 1 .^{\circ}$ Os nubentes, mediante declaração ao oficial de registro civil, podem escolher qualquer dos regimes de bens estabelecidos neste Estatuto.

$\S 2 .^{\circ}$ Não havendo declaração, vigora o regime da comunhão parcial de bens.

$\S 3 .^{\circ}$ Mediante escritura pública os nubentes podem estipular regime de bens não previsto neste Estatuto, desde que não contrarie suas regras e princípios.

$\S 4 .^{\circ} \mathrm{O}$ regime de bens começa a produzir efeitos na data do casamento e cessa com o fim da comunhão de vida.

$\S 5 .^{\circ}$ Com a separação de fato cessa a responsabilidade de cada um dos cônjuges para com as dívidas que vierem a ser contraídas pelo outro.

Art. 39. É admissível a alteração do regime de bens, mediante escritura pública, promovida por ambos os cônjuges, assistidos por advogado ou defensor público, ressalvados os direitos de terceiros.

$\S 10^{\circ}$ A alteração não dispõe de efeito retroativo.

$\S 2 .^{\circ}$ A alteração produz efeito a partir da averbação no assento de casamento.

Art. 40. Independentemente do regime de bens, qualquer dos cônjuges pode livremente:

I - administrar e alienar os bens particulares, exceto os bens móveis que guarnecem a residência da família;

II - praticar os atos de disposição e administração necessários ao desempenho de sua profissão;

III - reivindicar os bens comuns, doados, gravados ou transferidos pelo outro cônjuge sem o seu consentimento;

IV - demandar a resolução dos contratos de fiança e doação, realizados pelo outro cônjuge.

$\S 1 .^{\circ}$ As ações fundadas nos incisos III e IV competem ao cônjuge prejudicado e a seus herdeiros.

$\S 2 .^{\circ} \mathrm{O}$ terceiro prejudicado tem direito regressivo contra o cônjuge que realizou o negócio jurídico, ou contra os seus herdeiros.

Art. 41. Pode o cônjuge, independentemente da autorização do outro:

I - comprar, ainda que a crédito, o necessário à manutenção da família;

II - obter, por empréstimo, as quantias que tais aquisições possam exigir.

Parágrafo único. As dívidas contraídas para os fins deste artigo obrigam solidariamente ambos os cônjuges. 
Art. 42. Nenhum dos cônjuges pode, sem autorização do outro, exceto no regime da separação:

I - vender, doar, permutar, dar em pagamento, ceder ou gravar de ônus real os bens comuns;

II - pleitear, como autor ou réu, acerca desses bens ou direitos;

III - prestar fiança.

Parágrafo único. Cabe o suprimento judicial do consentimento quando um dos cônjuges o denegue sem motivo justo, ou lhe seja impossível concedê-lo.

Art. 43. A anulação dos atos praticados sem outorga, sem consentimento, ou sem suprimento do juiz, pode ser demandada pelo cônjuge a quem cabia concedê-la, ou por seus herdeiros, até um ano da homologação da partilha.

Art. 44. Quando um dos cônjuges não puder exercer a gestão dos bens que the incumbe, cabe ao outro:

I - gerir os bens, comuns ou não;

II - alienar os bens móveis comuns;

III - alienar os imóveis e os bens móveis, comuns ou não, mediante autorização judicial.

\section{SUBSEÇÃO II}

DO REGIME DE COMUNHÃO PARCIAL

Art. 45. No regime de comunhão parcial, comunicam-se:

I - os bens adquiridos na constância do casamento, inclusive as economias derivadas de salários, indenizações, verbas trabalhistas rescisórias e rendimentos de um só dos cônjuges;

II - os bens adquiridos por fato eventual, com ou sem o concurso de trabalho ou despesa;

III - os bens recebidos por doação, herança ou legado, em favor de ambos os cônjuges;

IV - as pertenças e as benfeitorias em bens particulares de cada cônjuge;

$\mathrm{V}$ - os frutos dos bens comuns, ou dos particulares de cada cônjuge, percebidos na constância do casamento, ou pendentes quando cessada a vida em comum.

Art. 46. Excluem-se da comunhão:

I - os bens que cada cônjuge possuir ao casar, e os que lhe sobrevierem, na constância do casamento, por doação ou sucessão, e os subrogados em seu lugar; 
II - os bens adquiridos com valores exclusivamente pertencentes a um dos cônjuges ou em sub-rogação dos bens particulares;

III - as obrigações anteriores ao casamento, salvo se reverterem em proveito comum;

IV - as obrigações provenientes de ato ilícito, salvo reversão em proveito do casal;

$\mathrm{V}$ - os bens cuja aquisição tiver por título causa anterior ao casamento;

VI - os bens de uso pessoal, os livros e instrumentos de profissão.

$\S 1 .^{\circ}$ Os instrumentos de profissão incluem-se na comunhão quando houver a participação do outro na sua aquisição.

$\S 2 .^{\circ}$ Presumem-se adquiridos na constância do casamento os bens móveis, quando não provado que o foram em data anterior.

Art. 47. A gestão do patrimônio comum compete a ambos os cônjuges.

§ 1.o É necessária a anuência de ambos os cônjuges para os atos, a título gratuito, que impliquem cessão do uso ou gozo dos bens comuns.

$\S 2$.o Em caso de malversação dos bens comuns, ou de outra hipótese similar, pode ser atribuída a gestão a apenas um dos cônjuges ou antecipada a partilha.

Art. 48. Os bens da comunhão respondem pelas obrigações contraídas por qualquer dos cônjuges para atender aos encargos da família, às despesas de gestão e às decorrentes de imposição legal.

Art. 49. A gestão dos bens constitutivos do patrimônio particular compete ao cônjuge proprietário, salvo estipulação diversa.

Art. 50. As dívidas, contraídas por qualquer dos cônjuges na administração e em benefício de seus bens particulares, não obrigam os bens comuns.

Parágrafo único. As dívidas contraídas por qualquer dos cônjuges obrigam os bens do outro na razão do proveito que houver auferido.

SUBSEÇÃO III

\section{DO REGIME DA COMUNHÃO UNIVERSAL}

Art. 51. O regime de comunhão universal importa a comunicação de todos os bens presentes e futuros dos cônjuges e de suas dívidas.

Art. 52. São excluídos da comunhão:

I - os bens doados ou herdados com a cláusula de incomunicabilidade e os subrogados em seu lugar;

II - as dívidas anteriores ao casamento, salvo se reverterem em proveito comum;

III - as obrigações provenientes de ato ilícito; 
IV - os bens de uso pessoal, os livros e instrumentos de profissão.

$\S 1 .^{\circ}$ Os instrumentos de profissão entram na comunhão se foram adquiridos com esforço do outro cônjuge.

$\S 2 .^{\circ}$ A incomunicabilidade não se estende aos frutos, quando se percebam ou vençam durante o casamento.

\section{SUBSEÇÃO IV}

\section{DO REGIME DE SEPARAÇÃO DE BENS}

Art. 53. O regime da separação de bens importa incomunicabilidade completa dos bens adquiridos antes e durante o casamento.

Parágrafo único. Os bens ficam na administração exclusiva do respectivo cônjuge, que os poderá livremente alienar ou gravar de ônus real.

SEÇÃO VII

DO DIVÓRCIO E DA SEPARAÇÃO

\section{SUBSEÇÃO I}

\section{DO DIVÓRCIO}

Art. 54. O divórcio dissolve o casamento civil.

$\S 1 .^{\circ} \mathrm{O}$ divórcio direto se dá após a separação de fato por mais de dois anos.

$\S 2 .^{\circ}$ A separação de fato se configura quando cessa a convivência entre os cônjuges, ainda que residindo sob o mesmo teto.

Art. 55. O divórcio pode ser litigioso ou consensual.

Parágrafo único. O divórcio consensual pode ser judicial ou extrajudicial.

Art. 56. A separação de fato põe termo aos deveres conjugais e ao regime de bens.

\section{SUBSEÇÃO II}

DA SEPARAÇÃO

Art. 57. É facultado aos cônjuges pôr fim à sociedade conjugal, mediante separação judicial ou extrajudicial.

$\S 1 .^{\circ}$ A iniciativa da separação pode ser de um ou de ambos os cônjuges.

$\S 2 .^{\circ}$ A separação de corpos pode ser deferida pelo juiz antes ou no curso do processo.

$\S 3 .^{\circ}$ A separação de corpos põe termo aos deveres conjugais e ao regime de bens.

Art. 58. Após um ano da separação de corpos ou da separação judicial ou extrajudicial, o divórcio pode ser requerido por um ou por ambos os cônjuges. 
Art. 59. No divórcio e na separação são necessário:

I - definir a guarda e a convivência com os filhos menores ou incapazes;

II - dispor acerca dos alimentos;

III - deliberar sobre a manutenção ou alteração do nome adotado no casamento; e

IV - descrever e partilhar os bens.

Parágrafo único. A partilha de bens pode ser levada a efeito posteriormente.

Art. 60. O divórcio e a separação não modificam os direitos e deveres dos pais em relação aos filhos.

Art. 61. O pedido de divórcio ou de separação compete exclusivamente aos cônjuges. Parágrafo único. Quando um dos cônjuges estiver acometido de doença mental ou transtorno psíquico, somente é possível o divórcio ou a separação judicial, devendo o incapaz ser representado por curador, ascendente ou irmão.

Art. 62. O divórcio e a separação consensuais podem ser realizados por escritura pública, com a assistência de advogado ou defensor público:

I - não tendo o casal filhos menores ou incapazes; ou

II - quando as questões relativas aos filhos menores ou

incapazes já se encontrarem judicialmente definidas.

CAPÍTULO III

DA UNIÃO ESTÁVEL

Art. 63. É reconhecida como entidade familiar a união estável entre o homem e a mulher, configurada na convivência pública, contínua, duradoura e estabelecida com o objetivo de constituição de família.

Parágrafo único. A união estável constitui estado civil de convivente, independentemente de registro, o qual deve ser declarado em todos os atos da vida civil.

Art. 64. A união estável não se constitui:

I - entre parentes na linha reta, sem limitação de grau;

II - entre parentes na linha colateral até o terceiro grau, inclusive;

III - entre parentes por afinidade em linha reta.

Parágrafo único. A união formada em desacordo aos impedimentos legais não exclui os deveres de assistência e a partilha de bens.

Art. 65. As relações pessoais entre os conviventes obedecem aos deveres de lealdade, respeito e assistência recíproca, bem como o de guarda, sustento e educação dos filhos. 
Art. 66. Na união estável, os conviventes podem estabelecer o regime jurídico patrimonial mediante contrato escrito.

$\S 1 .^{\circ} \mathrm{Na}$ falta de contrato escrito aplica-se às relações patrimoniais, no que couber, o regime da comunhão parcial de bens.

$\S 2 .^{\circ}$ A escolha do regime de bens não tem efeito retroativo.

Art. 67. A união estável pode converter-se em casamento, mediante pedido formulado pelo casal ao oficial de registro civil, no qual declarem que não têm impedimentos para casar e indiquem o regime de bens que passam a adotar, dispensada a celebração.

Parágrafo único. Os efeitos da conversão se produzem a partir da data do registro do casamento.

\section{CAPÍTULO IV}

\section{DA UNIÃO HOMOAFETIVA}

Art. 68. É reconhecida como entidade familiar a união entre duas pessoas de mesmo sexo, que mantenham convivência pública, contínua, duradoura, com objetivo de constituição de família, aplicando-se, no que couber, as regras concernentes à união estável.

Parágrafo único. Dentre os direitos assegurados, incluem-se:

I - guarda e convivência com os filhos;

II - a adoção de filhos;

III - direito previdenciário;

IV - direito à herança.

CAPÍTULO V

DA FAMÍLIA PARENTAL

Art. 69. As famílias parentais se constituem entre pessoas com relação de parentesco entre si e decorrem da comunhão de vida instituída com a finalidade de convivência familiar.

$\S 1 .^{\circ}$ Família monoparental é a entidade formada por um ascendente e seus descendentes, qualquer que seja a natureza da filiação ou do parentesco.

$\S 2 .^{\circ}$ Família pluriparental é a constituída pela convivência entre irmãos, bem como as comunhões afetivas estáveis existentes entre parentes colaterais.

TÍTULO IV

DA FILIAÇÃO

CAPÍTULO I 


\section{DISPOSIÇÕES GERAIS}

Art. 70. Os filhos, independentemente de sua origem, têm os mesmos direitos e qualificações, proibidas quaisquer designações e práticas discriminatórias.

Art. 71. A filiação prova-se pelo registro de nascimento.

$\S 1 .^{\circ}$ Os pais devem registrar os filhos no prazo de trinta dias do nascimento.

$\S 2 .^{\circ}$ Também se prova a filiação por qualquer modo admissível em direito, quando houver posse de estado de filho.

Art. 72. Os filhos não registrados podem ser reconhecidos pelos pais, conjunta ou separadamente.

$\S 1 .^{\circ} \mathrm{O}$ reconhecimento dos filhos é feito:

I - por documento particular ou escritura pública;

II - por testamento, ainda que incidentalmente manifestado;

III - por manifestação direta e expressa perante o juiz, mesmo que o reconhecimento não haja sido o objeto único e principal do ato que o contém.

$\S 2 .^{\circ} \mathrm{O}$ ato de reconhecimento deve ser levado ao registro de nascimento.

$\S 3 .^{\circ} \mathrm{O}$ reconhecimento pode preceder o nascimento do filho ou ser posterior ao seu falecimento, se ele deixar descendentes.

$\S 4 .^{\circ} \mathrm{O}$ reconhecimento não pode ser revogado, nem mesmo quando feito em testamento.

$\S 5 .^{\circ}$ São ineficazes a condição e o termo apostos ao ato de reconhecimento.

Art. 73. Presumem-se filhos:

I - os nascidos durante a convivência dos genitores à época da concepção;

II - os havidos por fecundação artificial homóloga, desde que a implantação do embrião tenha ocorrido antes do falecimento do genitor;

III - os havidos por inseminação artificial heteróloga, desde que realizada com prévio consentimento livre e informado do marido ou do convivente, manifestado por escrito, e desde que a implantação tenha ocorrido antes do seu falecimento.

Art. 74. O filho registrado ou reconhecido pode impugnar a paternidade, desde que não caracterizada a posse do estado de filho em relação àquele que o registrou ou o reconheceu.

Parágrafo único. $\mathrm{O}$ filho maior não pode ser registrado ou reconhecido voluntariamente sem o seu consentimento.

Art. 75. O filho não registrado ou não reconhecido pode, a qualquer tempo, investigar a paternidade ou a maternidade, biológica ou socioafetiva. 
Parágrafo único. A sentença que julgar procedente a investigação produz os mesmos efeitos do reconhecimento voluntário.

Art. 76. Cabe ao marido, ao convivente ou à mulher o direito de impugnar a paternidade ou a maternidade que lhe for atribuída no registro civil.

$\S$ 1. ${ }^{\circ}$ Impugnada a filiação, se sobrevier a morte do autor os herdeiros podem prosseguir na ação.

$\S 2 .^{\circ}$ Não cabe a impugnação da paternidade ou maternidade:

I - em se tratando de inseminação artificial heteróloga, salvo alegação de dolo ou fraude;

II - caso fique caracterizada a posse do estado de filho.

Art. 77. É admissível a qualquer pessoa, cuja filiação seja proveniente de adoção, filiação socioafetiva, posse de estado ou de inseminação artificial heteróloga, o conhecimento de seu vínculo genético sem gerar relação de parentesco.

Parágrafo único. $\mathrm{O}$ ascendente genético pode responder por subsídios necessários à manutenção do descendente, salvo em caso de inseminação artificial heteróloga.

CAPÍTULO II

DA ADOÇÃO

Art. 78. A adoção deve atender sempre ao melhor interesse do adotado e é irrevogável.

Parágrafo único. A adoção de crianças e adolescentes é regida por lei especial, observadas as regras e princípios deste Estatuto.

Art. 79. A adoção atribui a situação de filho ao adotado, desligando-o de qualquer vínculo com os pais e parentes consangüíneos, salvo quanto aos impedimentos para o casamento e a união estável.

Parágrafo único. Mantêm-se os vínculos de filiação entre o adotado e o cônjuge, companheiro ou parceiro do adotante e respectivos parentes.

Art. 80. Não podem adotar os ascendentes e os irmãos do adotando.

Art. 81. Tratando-se de grupo de irmãos, devem prioritariamente ser adotados por uma mesma família, preservados os vínculos fraternos.

Parágrafo único. Somente é admitido o desmembramento mediante parecer técnico indicativo da inexistência de laços afetivos entre os irmãos, ou se a medida atender aos seus interesses.

Art. 82. A morte dos adotantes não restabelece o parentesco anterior.

Art. 83. O adotado pode optar pela substituição ou adição do sobrenome do adotante. 
Art. 84. As relações de parentesco se estabelecem entre o adotado e o adotante e entre os parentes deste.

Art. 85. A adoção obedece a processo judicial.

$\S 1^{\circ}$ A adoção pode ser motivadamente impugnada pelos pais.

§ $2 .^{\circ}$ É indispensável a concordância do adotando.

Art. 86. Os efeitos da adoção começam a partir do trânsito em julgado da sentença, exceto se o adotante vier a falecer no curso do procedimento, caso em que terá força retroativa à data do óbito.

CAPÍTULO III

DA AUTORIDADE PARENTAL

Art. 87. A autoridade parental deve ser exercida no melhor interesse dos filhos.

$\S 1 .^{\circ}$ Compete a autoridade parental aos pais; na falta ou impedimento de um deles, o outro a exerce com exclusividade.

$\S 2 .^{\circ} \mathrm{O}$ filho tem o direito de ser ouvido, nos limites de seu discernimento e na medida de seu processo educacional.

$\S 3 .^{\circ}$ Aos pais incumbe o dever de assistência moral e material, guarda, educação e formação dos filhos menores.

Art. 88. A dissolução da entidade familiar não altera as relações entre pais e filhos.

Art. 89. Compete aos pais:

I - representar os filhos até dezesseis anos e assisti-los, após essa idade, até atingirem a maioridade;

II - nomear-lhes tutor por testamento ou documento particular.

Art. 90. Extingue-se a autoridade parental:

I - pela morte dos pais ou do filho;

II - pela emancipação;

III - pela maioridade;

IV - pela adoção;

V - por decisão judicial.

Art. 91. Constituindo os pais nova entidade familiar, os direitos e deveres decorrentes da autoridade parental são exercidos com a colaboração do novo cônjuge ou convivente ou parceiro.

Parágrafo único. Cada cônjuge, convivente ou parceiro deve colaborar de modo apropriado no exercício da autoridade parental, em relação aos filhos do outro, e representá-lo quando as circunstâncias o exigirem. 
Art. 92. Os pais, no exercício da autoridade parental, são gestores dos bens dos filhos.

Parágrafo único. Não podem os pais alienar, ou gravar de ônus real os imóveis dos filhos, nem contrair, em nome deles, obrigações que ultrapassem os limites da simples administração, salvo por necessidade ou evidente interesse da prole, mediante prévia autorização judicial.

Art. 93. Sempre que no exercício da autoridade parental colidir o interesse dos pais com o do filho, a requerimento deste ou do Ministério Público, o juiz deve nomearlhe curador especial.

Art. 94. Perde por ato judicial a autoridade parental aquele que não a exercer no melhor interesse do filho, em casos como assédio ou abuso sexual, violência física e abandono material, moral ou afetivo.

$\S 1 .^{\circ}$ A perda da autoridade parental não implica a cessação da obrigação alimentar dos pais e nem afeta os direitos sucessórios do filho.

$\S 2 .^{\circ}$ Os pais que perdem a autoridade parental também perdem os direitos sucessórios em relação ao filho.

Art. 95. É possível, no melhor interesse do filho, o restabelecimento da autoridade parental por meio de decisão judicial.

CAPÍTULO IV

DA GUARDA DOS FILHOS E DO DIREITO À CONVIVÊNCIA

Art. 96. A guarda dos filhos e o direito à convivência devem ser definidos nos casos de:

I - separação dos pais;

II - divórcio;

III - invalidade do casamento;

IV - dissolução da união estável e da união homoafetiva;

$\mathrm{V}$ - os pais não coabitarem.

Art. 97. Não havendo acordo entre os pais, deve o juiz decidir, preferencialmente, pela guarda compartilhada, salvo se o melhor interesse do filho recomendar a guarda exclusiva, assegurado o direito à convivência do não guardião.

Parágrafo único. Antes de decidir pela guarda compartilhada, sempre que possível, deve ser ouvida equipe multidisciplinar e utilizada a mediação familiar.

Art. 98. Os filhos não podem ser privados da convivência familiar com ambos os pais, quando estes constituírem nova entidade familiar. 
Art. 99. O não-guardião pode físcalizar o exercício da guarda, acompanhar o processo educacional e exigir a comprovação da adequada aplicação dos alimentos pagos.

Art. 100. O direito à convivência pode ser estendido a qualquer pessoa com quem a criança ou o adolescente mantenha vínculo de afetividade.

Art. 101. Quando a guarda é exercida exclusivamente por um dos genitores é indispensável assegurar o direito de convivência com o não-guardião.

Parágrafo único. $\mathrm{O}$ direito à convivência familiar pode ser judicialmente suspenso ou limitado quando assim impuser o melhor interesse da criança.

Art. 102. As disposições relativas à convivência familiar dos filhos menores estendem-se aos maiores incapazes.

Art. 103. Verificando que os filhos não devem permanecer sob a guarda do pai ou da mãe, o juiz deve deferir a guarda a quem revele compatibilidade com a natureza da medida, de preferência levando em conta o grau de parentesco e relação de afetividade.

Parágrafo único. Nesta hipótese deve ser assegurado aos pais o direito à convivência familiar, salvo se não atender ao melhor interesse da criança.

TÍTULO V

DA TUTELA E DA CURATELA

CAPÍTULO I

DA TUTELA

Art. 104. As crianças e os adolescentes são postos em tutela quando a nomeação for feita pelos pais em testamento ou documento particular, produzindo efeitos com a morte ou perda da autoridade parental.

Art. 105. É ineficaz a nomeação de tutor pelo pai ou pela mãe que, ao tempo de sua morte, não exercia a autoridade parental.

$\S 1 .^{\circ}$ Nomeado mais de um tutor sem indicação de precedência, entende-se que a tutela foi atribuída ao primeiro, e que os outros lhe sucederão pela ordem de nomeação.

$\S 2$. $^{\circ}$ É possível a instituição de dois tutores quando constituem uma entidade familiar.

Art. 106. Quem institui um menor de idade herdeiro, ou legatário seu, pode nomearlhe curador especial para os bens deixados, ainda que o beneficiário se encontre sob a autoridade parental, ou tutela. 
Art. 107. Na falta de tutor nomeado pelos pais ou no caso de recusa, o órfão deve ser colocado em família substituta, nos termos da legislação especial.

Art. 108. O tutor deve se submeter às mesmas regras da autoridade parental, sob pena de destituição judicial do encargo.

\section{CAPÍTULO II}

\section{DA CURATELA}

Art. 109. Rege-se o instituto da curatela pelo princípio do melhor interesse do curatelado.

Art. 110. Estão sujeitos à curatela:

I - os que, por enfermidade ou deficiência mental, não tiverem o necessário discernimento para a prática dos atos da vida civil;

II - os que, mesmo por causa transitória, não puderem exprimir a sua vontade;

III - os ébrios habituais, os viciados em tóxicos, e os que, por deficiência mental, tenham discernimento reduzido;

IV - os excepcionais sem desenvolvimento mental completo.

Art. 111. É nomeado curador, preferencialmente:

I - o cônjuge, o convivente ou o parceiro do interdito;

II - o ascendente ou o descendente que se demonstrar mais apto.

Parágrafo único. Na falta das pessoas mencionadas neste artigo, compete ao juiz a escolha do curador.

Art. 112. Não pode ser curador:

I - quem não tem a livre administração de seus bens;

II - quem tem obrigações para com curatelado, ou direitos contra ele;

III - o inimigo do curatelado;

IV - o condenado por crime contra a família;

$\mathrm{V}$ - o culpado de abuso em curatela anterior.

Art. 113. Quem esteja impossibilitado ou limitado no exercício regular dos atos da vida civil pode requerer que lhe seja dado curador para cuidar de seus negócios ou bens.

Parágrafo único. O pedido pode ser formulado por quem tenha legitimidade para ser nomeado curador.

Art. 114. O curador tem o dever de prestar contas de sua gestão de dois em dois anos. TÍTULO VI

DOS ALIMENTOS 
Art. 115. Podem os parentes, cônjuges, conviventes ou parceiros pedir uns aos outros os alimentos de que necessitem para viver com dignidade e de modo compatível com a sua condição social.

$\S 1$. $^{\circ}$ São devidos os alimentos quando o alimentando não tem bens suficientes a gerar renda, nem pode prover, pelo seu trabalho, à própria mantença.

$\S 2 .^{\circ}$ Os alimentos devem ser fixados na proporção das necessidades do alimentando e dos recursos do alimentante.

$\S 3 .^{\circ}$ Os alimentos devidos aos parentes são apenas os indispensáveis à subsistência, quando o alimentando der causa à situação de necessidade.

$\S 4 .^{\circ}$ Se houver acordo, o alimentante pode cumprir sua obrigação mediante o fornecimento de moradia, sustento, assistência à saúde e educação.

Art. 116. O direito a alimentos é recíproco entre pais e filhos, e extensivo a todos os parentes em linha reta, recaindo a obrigação nos mais próximos em grau, uns em falta de outros, e aos irmãos.

Parágrafo único. A maioridade civil faz cessar a presunção de necessidade alimentar, salvo se o alimentando comprovadamente se encontrar em formação educacional, até completar vinte e cinco anos de idade.

Art. 117. Se o parente que deve alimentos em primeiro lugar não estiver em condições de suportar totalmente o encargo, serão chamados a concorrer os de grau imediato.

$\S 1$ 1. $^{\circ}$ Sendo várias as pessoas obrigadas a prestar alimentos, todas devem concorrer na proporção dos respectivos recursos.

$\S 2 .^{\circ}$ A responsabilidade alimentar entre parentes tem natureza complementar quando o parente de grau mais próximo não puder atender integralmente a obrigação.

Art. 118. Se, fixados os alimentos, sobrevier mudança da situação financeira do alimentante, ou na do alimentando, pode o interessado requerer a exoneração, a redução ou majoração do encargo.

Art. 119. A obrigação alimentar transmite-se ao espólio, até o limite das forças da herança.

Art. 120. O crédito a alimentos é insuscetível de cessão, compensação ou penhora.

Art. 121. Com o casamento, a união estável ou a união homoafetiva do alimentando, extingue-se o direito a alimentos.

$\S 1 .^{\circ}$ Com relação ao alimentando, cessa, também, o direito a alimentos, se tiver procedimento indigno, ofensivo a direito da personalidade do alimentante. 
$\S 2 .^{\circ}$ A nova união do alimentante não extingue a sua obrigação alimentar.

TÍTULO VII

DO PROCESSO E DO PROCEDIMENTO

CAPÍTULO I

DISPOSIÇÕES GERAIS

Art. 122. Os processos, nas relações de família, orientam-se pelos princípios da oralidade, celeridade, simplicidade, informalidade, fungibilidade e economia processual.

Parágrafo único. As ações previstas neste Estatuto têm preferência de tramitação e julgamento.

Art. 123. As ações decorrentes deste Estatuto são da competência das Varas de Família e os recursos devem ser apreciados por Câmaras Especializadas em Direito de Família dos Tribunais de Justiça, onde houver.

$\S 1 .^{\circ}$ Enquanto não instaladas varas e câmaras especializadas, as ações e recursos serão processados e julgados nas varas e câmaras preferenciais, a serem indicadas pelos tribunais.

$\S 2 .^{\circ}$ As varas e câmaras especializadas ou com competência preferencial devem ser dotadas de equipe de atendimento multidisciplinar e de conciliadores.

Art. 124. As ações pertinentes às relações de família podem tramitar em segredo de justiça, quando for requerido justificadamente pelas partes.

Art. 125. As medidas de urgência podem ser propostas durante o período de férias forenses e devem ser apreciadas de imediato.

Art. 126. Nas questões decorrentes deste Estatuto, a conciliação prévia pode ser conduzida por juiz de paz ou por conciliador judicial.

Parágrafo único. Obtida a conciliação, o termo respectivo é submetido à homologação do juiz de direito competente.

Art. 127. As ações relativas ao mesmo núcleo familiar devem ser distribuídas ao mesmo juízo, ainda que não haja identidade de partes.

Art. 128. Em qualquer ação e grau de jurisdição deve ser buscada a conciliação e sugerida a prática da mediação extrajudicial, podendo ser determinada a realização de estudos sociais, bem como o acompanhamento psicológico das partes.

Art. 129. A critério do juiz ou a requerimento das partes, o processo pode ficar suspenso enquanto os litigantes se submetem à mediação extrajudicial ou a atendimento multidisciplinar. 
Art. 130. O Ministério Público deve intervir nos processos judiciais em que houver interesses de crianças, adolescentes e incapazes.

Art. 131. É das partes o ônus de produzir as provas destinadas a demonstrar suas alegações, competindo ao juiz investigar livremente os fatos e ordenar de ofício a realização de quaisquer provas.

Parágrafo único. Inverte-se o ônus da prova, ficando o encargo probatório a quem contrapõe interesse indisponível de criança, adolescente e incapaz.

Art. 132. O juiz pode adotar em cada caso a solução mais conveniente ou oportuna para atender o direito das partes, à luz dos princípios deste Estatuto.

Art. 133. Em todas as ações pode ser concedida a antecipação de tutela, bem como cumuladas medidas cautelares.

Parágrafo único. A apreciação do pedido liminar ou da tutela antecipada não depende da prévia manifestação do Ministério Público.

Art. 134. Na inexistência de prova inequívoca, ou não se convencendo da verossimilhança das alegações, para a apreciação da medida liminar, o juiz pode designar audiência de justificação, a ser realizada no prazo máximo de dez dias.

$\S 1 .^{\circ}$ A requerimento do autor, a audiência de justificação pode realizar-se sem a intimação do réu, caso haja a possibilidade de sua presença comprometer o cumprimento da medida.

$\S 2 .^{\circ} \mathrm{O}$ autor pode comparecer acompanhado de no máximo três testemunhas.

$\S 3 .^{\circ}$ Apreciado o pedido liminar, com a ouvida do Ministério Público, deve o juiz designar audiência conciliatória.

$\S 4$ 4 $^{\circ}$ Da decisão liminar cabe pedido de reconsideração, no prazo de cinco dias.

$\S 5 .^{\circ} \mathrm{Da}$ decisão que aprecia o pedido de reconsideração cabe agravo de instrumento.

Art. 135. Nas ações concernentes às relações de família deve o juiz designar audiência de conciliação, podendo imprimir o procedimento sumário.

Art. 136. Não obtida a conciliação, as partes podem ser encaminhadas a estudo psicossocial ou a mediação extrajudicial.

Parágrafo único. Cabe ao juiz homologar o acordo proposto pelo conciliador ou mediador com assistência dos advogados ou defensores públicos.

Art. 137. Aplicam-se subsidiariamente as disposições processuais constantes na legislação ordinária, e especial.

CAPÍTULO II

DO PROCEDIMENTO PARA O CASAMENTO 


\section{SEÇÃO I}

\section{DA HABILITAÇÃO}

Art. 138. A habilitação para o casamento é feita perante o oficial do Registro Civil da residência de qualquer dos nubentes.

Art. 139. O pedido de habilitação deve ser formulado por ambos os nubentes, ou por procurador com poderes especiais, mediante declaração da inexistência de impedimento para o casamento.

Parágrafo único. O pedido deve ser acompanhado dos seguintes documentos:

I - certidão de nascimento ou documento equivalente;

II - comprovação do domicílio e da residência dos nubentes;

III - declaração de duas testemunhas, parentes ou não, que atestem conhecê-los e afirmem não existir impedimento para o casamento;

IV - em caso de casamento anterior, certidão de óbito do cônjuge falecido, registro da sentença de divórcio ou da anulação do casamento;

$\mathrm{V}$ - havendo necessidade de autorização, documento firmado pelos pais, pelos representantes legais ou ato judicial que supra a exigência.

Art. 140. O oficial deve extrair edital, que permanecerá afixado durante quinze dias nas circunscrições do Registro Civil da residência de ambos os nubentes.

Art. 141. É dever do oficial do Registro esclarecer aos nubentes a respeito dos fatos que podem ocasionar a invalidade do casamento, bem como sobre os diversos regimes de bens.

Art. 142. Os impedimentos devem ser opostos por escrito e instruídos com as provas do fato alegado, ou com a indicação do lugar onde as provas possam ser obtidas.

Art. 143. O oficial do Registro deve apresentar aos nubentes ou a seus representantes a oposição.

Parágrafo único. Pode ser deferido prazo razoável para a prova contrária aos fatos alegados.

Art. 144. Verificada a inexistência do fato impeditivo para o casamento, será extraído o certificado de habilitação.

Art. 145. A eficácia da habilitação será de noventa dias, a contar da data em que foi extraído o certificado.

SEÇÃO II

DO SUPRIMENTO DE CONSENTIMENTO PARA O CASAMENTO 
Art. 146. Recusando um dos pais ou o representante a autorização para o casamento do relativamente incapaz, cabe ao outro pedir o suprimento judicial do consentimento.

$\S 1 .^{\circ}$ Recusada a autorização, o procedimento pode ser intentado pelo Ministério Público ou curador especial nomeado pelo juiz.

$\S 2 .^{\circ}$ Quem recusar a autorização, deve justificar a recusa no prazo de cinco dias.

$\S 3 .^{\circ} \mathrm{O}$ juiz pode determinar a realização de audiência ou a produção de provas, devendo decidir em até cinco dias.

\section{SEÇÃO III}

\section{DA CELEBRAÇÃO}

Art. 147. O casamento deve ser celebrado pelo juiz de paz em dia, hora e lugar previamente agendados.

Parágrafo único. Na falta do juiz de paz, é competente a autoridade celebrante na forma da organização judiciária de cada Estado.

Art. 148. A solenidade é realizada na sede do cartório, ou em outro local, com toda a publicidade, a portas abertas, e na presença de pelo menos duas testemunhas, parentes ou não dos nubentes.

Art. 149. Presentes os nubentes, as testemunhas e o oficial do Registro, o juiz de paz, ouvindo dos nubentes a afirmação de que pretendem casar por livre e espontânea vontade, os declarará casados, em nome da lei.

Art. 150. A celebração do casamento será imediatamente suspensa se algum dos nubentes:

I - recusar a solene afirmação da sua vontade;

II - declarar que sua manifestação não é livre e espontânea;

III - mostrar-se arrependido.

Parágrafo único. O nubente que der causa à suspensão do ato não poderá retratar-se no mesmo dia.

Art. 151. Um ou ambos os nubentes podem ser representados mediante procuração outorgada por instrumento público, com poderes especiais e com o prazo de noventa dias.

$\S 1 .^{\circ}$ A revogação da procuração somente pode ocorrer por escritura pública e antes da celebração do casamento.

$\S 2 .^{\circ}$ Celebrado o casamento, sem que a revogação chegue ao conhecimento do mandatário, o ato é inexistente, devendo ser cancelado. 
Art. 152. O casamento de brasileiro, celebrado no estrangeiro, perante a autoridade consular, deve ser registrado em cento e oitenta dias, a contar do retorno de um ou de ambos os cônjuges ao Brasil.

Parágrafo único. O registro deve ser feito no cartório do domicílio dos cônjuges em que residiam ou onde passarão a residir.

\section{SEÇÃO IV}

\section{DO REGISTRO DO CASAMENTO}

Art. 153. Celebrado o casamento, o oficial lavra o assento no livro de registro devendo constar:

I - os nomes, nacionalidade, data e lugar do nascimento, profissão e residência dos cônjuges;

II - os nomes, nacionalidade, data de nascimento dos pais, consignando o falecimento de algum deles;

III - a data e cartório que expediu o certificado de habilitação;

IV - os nomes, nacionalidade e domicílio das testemunhas;

V - o regime de bens do casamento e a identificação da escritura do pacto antenupcial;

VI - o nome que os cônjuges passam a usar.

Art. 154. O assento do casamento é assinado pelo juiz de paz, os cônjuges e por duas testemunhas.

\section{SEÇÃO V}

\section{DO REGISTRO DO CASAMENTO RELIGIOSO PARA EFEITOS CIVIS}

Art. 155. Os nubentes habilitados para o casamento podem casar perante autoridade ou ministro religioso.

Art. 156. O assento do casamento religioso, subscrito pela autoridade ou ministro que o celebrar, pelos nubentes e por duas testemunhas, deve conter os mesmos requisitos do registro civil.

Art. 157. A autoridade ou ministro celebrante deve arquivar a certidão de habilitação que lhe foi apresentada, devendo, nela, anotar a data da celebração do casamento.

Art. 158. No prazo de trinta dias, a contar da celebração, qualquer interessado pode apresentar o assento do casamento religioso ao cartório do registro civil que expediu o certificado de habilitação.

$\S 1 .^{\circ} \mathrm{O}$ oficial deve proceder ao registro do casamento no prazo de vinte e quatro horas. 
§ 2. ${ }^{\circ}$ Se o documento referente à celebração do casamento religioso omitir algum requisito, a falta deve ser suprida por declaração de ambos os cônjuges, tomada por termo pelo oficial.

Art.159. Do assento devem constar a data da celebração, o lugar e o culto religioso.

Art. 160. O casamento religioso, celebrado sem a prévia habilitação perante o oficial de registro civil, pode ser registrado no prazo noventa dias, mediante requerimento dos cônjuges, com a prova do ato religioso e os demais documentos exigidos para a habilitação do casamento.

Parágrafo único. Processada a habilitação, o oficial procede ao registro do casamento religioso, devendo atender aos mesmos requisitos legais.

Art. 161. O casamento produz efeitos a contar da celebração religiosa.

SEÇÃO VI

DO CASAMENTO EM IMINENTE RISCO DE MORTE

Art. 162. Quando algum dos nubentes estiver em iminente risco de morte, não obtendo a presença do juiz de paz, pode o casamento ser celebrado na presença de quatro testemunhas, que não tenham com os nubentes relação de parentesco.

Art. 163. Realizado o casamento, devem as testemunhas comparecer perante o cartório do registro civil mais próximo, dentro de dez dias, devendo ser tomada a termo a declaração de:

I - que foram convocadas por parte do enfermo;

II - que este parecia em perigo de morte, mas apresentava plena capacidade para manifestar sua vontade;

III - que, em sua presença, declararam os nubentes, livre e espontaneamente, receberse em casamento.

$\S 1 .^{\circ}$ Autuado o pedido e tomadas as declarações a termo, o oficial do registro civil deve proceder as diligências para verificar se os nubentes podiam ter-se habilitado, colhendo a manifestação do sobrevivente, em quinze dias.

$\S 2 .^{\circ}$ Comprovada a inexistência de impedimentos, o oficial procederá ao registro no livro do Registro dos Casamentos.

$\S 3 .^{\circ} \mathrm{O}$ casamento produz efeitos a partir da data da celebração.

$\S 4 .^{\circ}$ Serão dispensadas estas formalidades se o enfermo convalescer e ambos ratificarem o casamento na presença do juiz de paz e do oficial do registro.

$\S 5 .^{\circ}$ Neste caso fica dispensada a habilitação para o casamento.

CAPÍTULO III 


\section{DO RECONHECIMENTO DA UNIÃO ESTÁVEL E DA UNIÃO HOMOAFETIVA}

Art. 164. É facultado aos conviventes e aos parceiros, de comum acordo, requerer em juízo o reconhecimento de sua união estável ou da união homoafetiva.

Art. 165. Dissolvida a união, qualquer dos conviventes ou parceiros pode ajuizar a ação de reconhecimento de sua existência.

Parágrafo único. Na petição inicial deve a parte autora:

I - identificar o período da convivência;

II - indicar o regime da guarda dos filhos;

III - comprovar a necessidade de alimentos ou declarar que deles não necessita;

IV - indicar o valor dos alimentos necessários à mantença dos filhos;

$\mathrm{V}$ - descrever os bens do casal e apresentar proposta de divisão.

Art. 166. A ação deve ser instruída com o contrato de convivência, se existir, e a certidão de nascimento dos filhos.

Parágrafo único. A descrição dos bens do casal e a proposta de partilha é facultativa.

Art. 167. Ao receber a petição inicial, o juiz deve apreciaro pedido liminar de alimentos provisórios e designar audiência conciliatória.

Parágrafo único. A sentença deve fixar os termos inicial e final da união.

CAPÍTULO IV

DA DISSOLUÇÃO DA ENTIDADE FAMILIAR

SEÇÃO I

DA AÇÃO DE DIVÓRCIO

Art. 168. A ação de divórcio pode ser intentada por qualquer um dos cônjuges ou por ambos.

$\S 1^{\circ}$ O cônjuge acometido de doença mental ou transtorno psíquico será representado por curador, ascendente ou irmão.

$\S 2 .^{\circ}$ A inicial deverá ser acompanhada da certidão de casamento e certidão de nascimento dos filhos.

Art. 169. Não tendo havido prévia separação, deve a inicial:

I - indicar a data da separação de fato;

II - identificar o regime de convivência com os filhos menores;

III - declinar a dispensa dos alimentos ou a necessidade de um dos cônjuges de percebê-los;

IV - indicar o valor dos alimentos necessários à mantença dos filhos. 
Art. 170. Ao receber a inicial, o juiz deve apreciar o pedido liminar de alimentos provisórios.

Art. 171. Havendo filhos menores ou incapazes, deverá ser designada audiência conciliatória.

Art. 172. No divórcio consensual, não existindo filhos menores ou incapazes, ou estando judicialmente decididas as questões a eles relativas, é dispensável a realização de audiência.

\section{SEÇÃO II}

\section{DA SEPARAÇÃO}

Art. 173. Qualquer dos cônjuges pode propor a ação de separação.

Art. 174. Qualquer dos cônjuges, conviventes ou parceiros pode propor a ação de separação de corpos.

$\S 1 .^{\circ}$ A parte autora pode pleitear, justificadamente, sua permanência no lar ou requerer o afastamento da parte-ré.

$\S 2 .^{\circ}$ Havendo alegação da prática de violência doméstica, aplica-se a legislação especial.

Art. 175. Na inicial da ação de separação deve a parte autora:

I - indicar o regime de convivência com os filhos menores;

II - declarar que dispensa alimentos ou comprovar a necessidade de percebê-los;

III - indicar o valor dos alimentos necessários à mantença dos filhos.

Parágrafo único. A ação deve ser instruída com a certidão de casamento ou contrato de convivência, se existir, e a certidão de nascimento dos filhos.

Art. 176. Ao receber a petição inicial, o juiz deve apreciar o pedido de separação de corpos e decidir sobre os alimentos.

Parágrafo único. Não evidenciada a possibilidade de risco à vida ou a saúde das partes e dos filhos, o juiz pode designar audiência de justificação ou de conciliação para decidir sobre a separação de corpos.

Art. 177. Comparecendo a parte-ré e concordando com a separação de corpos, pode a ação prosseguir quanto aos pontos em que inexista consenso.

CAPÍTULO V

DOS ALIMENTOS

SEÇÃO I

DA AÇÃO DE ALIMENTOS

Art. 178. Na ação de alimentos, o autor deve: 
I - comprovar a obrigação alimentar ou trazer os indícios da responsabilidade do alimentante em prover-lhe o sustento;

II - declinar as necessidades do alimentando;

III - indicar as possibilidades do alimentante.

Art. 179. Ao despachar a inicial, o juiz deve fixar alimentos provisórios e encaminhar as partes à conciliação, ou designar audiência de instrução e julgamento.

$\S 1 .^{\circ}$ Os alimentos provisórios são devidos e devem ser pagos desde a data da fixação.

$\S 2 .^{\circ}$ Quando da citação, deve o réu ser cientificado da incidência da multa de $10 \%$, sempre que incorrer em mora de quinze dias.

Art. $180 \mathrm{Se}$ o devedor for funcionário público, civil ou militar, empregado da iniciativa privada, perceber rendimentos provenientes de vínculo empregatício, ou for aposentado, o juiz deve fixar os alimentos em percentual dos seus ganhos.

Parágrafo único. O desconto dos alimentos será feito dos rendimentos do alimentante, independentemente de requerimento do credor, salvo acordo.

Art. 181. Na audiência de instrução e julgamento o juiz colherá o depoimento das partes.

$\S 1 .^{\circ}$ Apresentada a contestação, oral ou escrita, havendo prova testemunhal, o juiz ouvirá a testemunha, independentemente do rol.

$\S 2 .^{\circ}$ Ouvidas as partes e o Ministério Público, o juiz proferirá a sentença na audiência ou no prazo máximo de dez dias.

Art. 182. Da sentença que fixa, revisa ou exonera alimentos cabe recurso somente com efeito devolutivo.

Parágrafo único. Justificadamente, o juiz, ou o relator, pode agregar efeito suspensivo ao recurso.

Art. 183. Fixados alimentos definitivos em valor superior aos provisórios, cabe o pagamento da diferença desde a data da fixação. Caso os alimentos fixados em definitivo sejam em valor inferior aos provisórios, não há compensação, não dispondo a decisão de efeito retroativo.

Art. 184. Na ação de oferta de alimentos, o juiz não está adstrito ao valor oferecido pelo autor.

Art. 185. Cabe ação revisional quando os alimentos foram fixados sem atender ao critério da proporcionalidade ou quando houver alteração nas condições das partes. 
Art. 186. A ação de alimentos pode ser cumulada com qualquer demanda que envolva questões de ordem familiar entre as partes.

Art. 187. Havendo mais de um obrigado, é possível mover a ação contra todos, ainda que o dever alimentar de alguns dos réus seja de natureza subsidiária ou complementar.

Parágrafo único. A obrigação de cada um dos alimentantes deve ser individualizada.

Art. 188. O empregador, o órgão público ou privado responsável pelo pagamento do salário, benefício ou provento, no prazo de até quinze dias, tem o dever de:

I - proceder ao desconto dos alimentos;

II - encaminhar a juízo cópia dos seis últimos contracheques ou recibos de pagamento do salário;

III - informar imediatamente quando ocorrer a rescisão do contrato de trabalho ou a cessação do vínculo laboral.

Art. 189. Rescindido o contrato de trabalho do alimentante, serão colocadas à disposição do juízo 30\% de quaisquer verbas, rescisórias ou não, percebidas por ato voluntário do ex-empregador ou por decisão judicial.

$\S 1 .^{\circ}$ Desse crédito, mensalmente, será liberado, em favor dos alimentandos, o valor do pensionamento, até que os alimentos passem a ser pagos por outra fonte pagadora. $\S 2 .^{\circ}$ Eventual saldo será colocado à disposição do alimentante.

Art. 190. Fixada em percentual sobre os rendimentos do alimentante, a verba alimentar, salvo ajuste diverso, incide sobre:

I - a totalidade dos rendimentos percebidos a qualquer título, excluídos apenas os descontos obrigatórios, reembolso de despesas e diárias;

II - o $13^{\circ}$ salário, adicional de férias, gratificações, abonos, horas extras e vantagens recebidas a qualquer título.

Art. 191. A cessação do vínculo laboral não torna ilíquida a obrigação, correspondendo os alimentos, neste caso, ao último valor descontado.

Art. 192. Os alimentos podem ser descontados de aluguéis e de outras rendas ou rendimentos do alimentante, a serem pagos diretamente ao credor.

SEÇÃO II

DA COBRANÇA DOS ALIMENTOS

Art. 193. Fixados os alimentos judicialmente, a cobrança será levada a efeito como cumprimento de medida judicial. 
Art. 194. Podem ser cobrados pelo mesmo procedimento os alimentos fixados em escritura pública de separação e divórcio ou em acordo firmado pelas partes e referendado pelo Ministério Público, Defensoria Pública ou procurador dos transatores.

Art. 195. A cobrança dos alimentos provisórios, bem como a dos alimentos fixados em sentença sujeita a recurso, se processa em procedimento apartado.

Art. 196. Os alimentos definitivos, fixados em qualquer demanda, podem ser cobrados nos mesmos autos.

Art. 197. Cabe ao juiz tomar as providências cabíveis para localizar o devedor e seus bens, independentemente de requerimento do credor.

Art. 198. A multa incide sobre todas as parcelas vencidas há mais de quinze dias, inclusive as que se vencerem após a intimação do devedor.

Art. 199. Recaindo a penhora em dinheiro, o oferecimento de impugnação não obsta a que o credor levante mensalmente o valor da prestação.

Parágrafo único. Sem prejuízo do pagamento dos alimentos, o débito executado pode ser descontado dos rendimentos ou rendas do devedor, de forma parcelada, contanto que, somado à parcela devida, não ultrapasse 50\% de seus ganhos líquidos.

Art. 200. Para a cobrança de até seis parcelas de alimentos, fixadas judicial ou extrajudicialmente, o devedor será citado para proceder ao pagamento do valor indicado pelo credor, no prazo de três dias, provar que o fez ou justificar a impossibilidade de efetuá-lo.

Parágrafo único. Somente a comprovação de fato imprevisível que gere a impossibilidade absoluta de pagar servirá de justificativa para o inadimplemento.

Art. 201. O magistrado pode, a qualquer tempo, designar audiência conciliatória, para o fim de ajustar modalidades de pagamentos.

$\S 1 .^{\circ}$ Inadimplido o acordo, restará vencida a totalidade do débito, sem prejuízo do cumprimento da pena de prisão.

$\S 2$. $^{\circ}$ Se o devedor não pagar, ou o magistrado não aceitar a justificação apresentada, decretará a prisão pelo prazo de um a três meses.

Art. 202. A prisão será cumprida em regime semi-aberto;

em caso de novo aprisionamento, o regime será o fechado.

Art. 203. O devedor se exime da prisão comprovando o pagamento das parcelas executadas, das prestações vencidas até a data do adimplemento, dos juros e da correção monetária. 
Art. 204. Cumprida a prisão, e não levado a efeito o pagamento, a cobrança prossegue nos mesmos autos, pelo rito da execução por quantia certa.

Parágrafo único. Sobre a totalidade do débito e sobre as parcelas vencidas até a data do pagamento incide multa, a contar da data da citação.

Art. 205. As custas processuais e os honorários advocatícios podem ser cobrados nos mesmos autos.

Art. 206. Citado o réu, e deixando de proceder ao pagamento, o juiz determinará a inscrição do seu nome no Cadastro de Proteção ao Credor de Alimentos e demais instituições públicas ou privadas de proteção ao crédito.

$\S 1 .^{\circ} \mathrm{O}$ juiz deve comunicar o valor e o número das prestações vencidas e não pagas.

$\S 2 .^{\circ}$ A determinação não depende de requerimento do credor.

$\S 3 .^{\circ}$ Quitado o débito, a anotação é cancelada mediante ordem judicial.

Art. 207. Em qualquer hipótese, verificada a postura procrastinatória do devedor, o magistrado deverá dar ciência ao Ministério Público dos indícios da prática do delito de abandono material.

CAPÍTULO VI

DA AVERIGUAÇÃO DA FILIAÇÃO

Art. 208. Comparecendo o pai ou a mãe para proceder ao registro de nascimento do filho menor de idade somente em seu nome, o Oficial do Registro Civil deve comunicar ao Ministério Público, com as informações que lhe foram fornecidas para a localização do outro genitor.

Art. 209. O Ministério Público deve notificar o indicado como sendo genitor, para que, no prazo de dez dias, se manifeste sobre a paternidade ou maternidade que lhe é atribuída.

$\S 1 .^{\circ}$ Confirmada a paternidade ou a maternidade, lavrado o termo, o oficial deve proceder o registro.

$\S 2 .^{\circ}$ Negada a paternidade ou a maternidade, ou deixando de manifestar-se, cabe ao Ministério Público propor a ação investigatória.

Art. 210. A iniciativa conferida ao Ministério Público não impede a quem tenha legítimo interesse de intentar a ação de investigação.

CAPÍTULO VII

DA AÇÃO DE INVESTIGAÇÃO DE PATERNIDADE 
Art. 211. Proposta ação investigatória por menor de idade ou incapaz, havendo forte prova indiciária da paternidade, biológica ou socioafetiva, o juiz deve fixar alimentos provisórios, salvo se o autor declarar que deles não necessita.

Art. 212. Havendo registro civil é necessária a citação daqueles indicados no respectivo assento.

Art. 213. Postulando o autor sob o benefício da assistência judiciária, é de responsabilidade do réu os encargos necessários para a produção das provas, se ele não gozar do mesmo benefício.

Art. 214. Deixando o réu de submeter-se à perícia ou de injustificadamente proceder ao pagamento do exame, opera em favor do autor a presunção de veracidade dos fatos alegados na inicial.

Parágrafo único. A declaração da filiação deve ser apreciada em conjunto com outras provas.

Art. 215. A ausência de contestação enseja a aplicação dos efeitos da revelia.

Art. 216. A procedência do pedido desconstitui a filiação estabelecida anteriormente no registro.

Parágrafo único. A alteração do nome deve atender ao melhor interesse do investigante.

Art. 217. Transitada em julgado a sentença deve ser expedido mandado de averbação ao registro civil.

Art. 218. A sentença de procedência dispõe de efeito declaratório desde a data do nascimento do investigado.

Art. 219. A improcedência do pedido de filiação não impede a propositura de nova ação diante do surgimento de outros meios probatórios.

\section{CAPÍTULO VIII}

\section{DA AÇÃO DE INTERDIÇÃO}

Art. 220. A interdição pode ser promovida:

I - pelo cônjuge, companheiro ou parceiro;

II - pelos parentes consangüíneos ou afins;

III - pelo representante da entidade em que se encontra abrigado o interditando;

IV - pelo Ministério Público.

Art. 221. O Ministério Público só promoverá interdição:

I - em caso de doença mental grave; 
II - se não existir ou não promover a interdição alguma das pessoas designadas nos incisos I, II e III do artigo antecedente;

III - se, existindo, forem incapazes as pessoas mencionadas no inciso antecedente.

Art. 222. Cabe ao autor especificar os fatos que revelam a incapacidade do interditando para reger a sua pessoa e administrar os seus bens.

Parágrafo único. Justificada a urgência, o juiz pode nomear curador provisório ao interditando para a prática de determinados atos.

Art. 223. O interditando será intimado para comparecer à audiência de interrogatório.

$\S 1$. $^{\circ}$ O juiz deve ouvir o interditando pessoalmente acerca de sua vida, negócios, bens, consignando sua impressão pessoal sobre as condições do interrogando.

$\S 2 .^{\circ}$ O juiz, quando necessário, pode comparecer ao local onde se encontra o interditando para ouvi-lo.

Art. 224. No prazo de cinco dias contados da audiência, o interditando pode contestar o pedido, através de advogado.

Art. 225. Cabe ao juiz nomear perito para proceder ao exame do interditando.

Parágrafo único. O juiz pode dispensar a perícia, quando notória a incapacidade.

Art. 226. Apresentado o laudo pericial, após manifestação das partes, se necessário, o juiz designará audiência de instrução e julgamento.

Art. 227. A escolha do curador será feita pelo juiz e deverá recair na pessoa que melhor atenda aos interesses do curatelado.

Art. 228. Não poderá ser nomeado curador:

I - quem não tiver a livre administração de seus bens;

II - quem tiver obrigações para com o curatelado, ou direitos contra ele.

Art. 229. Decretada a interdição, o juiz fixará os limites da curatela segundo o estado ou o desenvolvimento mental do interdito.

Art. 230. Transitada em julgado, a sentença será inscrita no Registro de Pessoas Naturais.

Art. 231. O curador será intimado a prestar compromisso no prazo de cinco dias.

Art. 232. Prestado o compromisso, o curador assume a administração dos bens do interdito.

Art. 233. Havendo meio de recuperar o interdito, o curador deve buscar tratamento apropriado.

Art. 234. O interdito poderá ser recolhido em estabelecimento adequado, quando não se adaptar ao convívio doméstico. 
Art. 235. A autoridade do curador estende-se à pessoa e aos bens dos filhos menores do curatelado, que se encontram sob a guarda e responsabilidade deste ao tempo da interdição.

Art. 236. O curador deve prestar contas de sua gestão de dois em dois anos, ficando dispensado se renda for menor que três salários mínimos mensais.

Art. 237. O Ministério Público, ou quem tenha legítimo interesse, pode requerer a destituição do curador.

Art. 238. O curador pode contestar o pedido de destituição no prazo cinco dias.

Art. 239. Ao deixar o encargo, será indispensável a prestação de contas.

Art. 240. Em caso de extrema gravidade, o juiz pode suspender o exercício da curatela, nomeando interinamente substituto.

Art. 241. Extingue-se a interdição, cessando a causa que a determinou.

Parágrafo único. A extinção da curatela pode ser requerida pelo curador, pelo interditado ou pelo Ministério Público.

Art. 242. O juiz deverá nomear perito para avaliar as condições do interditado; após a apresentação do laudo, quando necessário, designará audiência de instrução e julgamento.

Art. 243. Extinta a interdição, a sentença será averbada no Registro de Pessoas Naturais.

\section{CAPÍTULO IX}

\section{DOS PROCEDIMENTOS DOS ATOS EXTRAJUDICIAIS}

Art. 244. Os atos extrajudiciais devem ser subscritos pelas partes e pelos advogados.

Parágrafo único. O advogado comum ou de cada uma das partes deve estar presente no ato da assinatura da respectiva escritura.

SEÇÃO I

DO DIVÓRCIO

Art. 245. Os cônjuges podem promover o divórcio por escritura pública.

Parágrafo único. Os cônjuges devem apresentar as certidões de casamento e de nascimento dos filhos, se houver.

Art. 246. Devem os cônjuges declarar:

I - a data da separação de fato;

II - o valor dos alimentos destinado a um dos cônjuges ou a dispensa de ambos do encargo alimentar;

III - a permanência ou não do uso do nome; 
IV - facultativamente, os bens do casal e sua partilha.

Parágrafo único. Não é necessária a partilha dos bens para o divórcio.

Art. 247. Havendo filhos menores ou incapazes, é necessário comprovar que se encontram solvidas judicialmente todas as questões a eles relativas.

Art. 248. Lavrada a escritura, deve o tabelião enviar certidão ao Cartório do Registro Civil em que ocorreu o casamento, para averbação.

$\S 1 .^{\circ}$ A certidão do divórcio deve ser averbada no registro de imóvel onde se situem os bens e nos registros relativos a outros bens.

$\S 2 .^{\circ} \mathrm{O}$ envio da certidão aos respectivos registros pode ser levado a efeito por meio eletrônico.

Art. 249. A eficácia do divórcio se sujeita à averbação no registro do casamento.

SEÇÃO II

DA SEPARAÇÃO

Art. 250. É facultada aos cônjuges a separação consensual extrajudicial.

Art. 251. A separação consensual extrajudicial de corpos cabe aos cônjuges, aos conviventes e aos parceiros.

Art. 252. A separação consensual pode ser levada a efeito por escritura pública, na hipótese de:

I - Não existir filhos menores ou incapazes do casal;

II - Estarem solvidas judicialmente todas as questões referentes aos filhos menores ou incapazes.

Art. 253. Na escritura deve ficar consignado o que ficou acordado sobre pensão alimentícia, e, se for o caso, sobre os bens comuns.

SEÇÃO III

DO RECONHECIMENTO E DA DISSOLUÇÃO DA UNIÃO ESTÁVEL E HOMOAFETIVA

Art. 254. Os conviventes e os parceiros podem, a qualquer tempo, buscar o reconhecimento da união por escritura pública, indicando:

I - a data do início da união;

II $-o$ regime de bens.

Art. 255. Encontrando-se os conviventes ou os parceiros separados, a dissolução da união pode ser realizada mediante escritura pública, devendo ser indicados:

I - o período da convivência;

II - o valor dos alimentos ou a dispensa do encargo; 
III - facultativamente, a descrição dos bens e a sua divisão.

Art. 256. Havendo filhos menores ou incapazes, as questões a eles relativas devem ser solvidas judicialmente.

Art. 257. Lavrada a escritura, cabe ao tabelião encaminhar certidão ao Cartório do Registro Civil da residência dos conviventes ou parceiros, a ser averbada em livro próprio.

Parágrafo único. A união será averbada no registro de nascimento dos conviventes e dos parceiros.

Art. 258. Havendo bens, deverá proceder-se ao registro na circunscrição dos imóveis e nos demais registros relativos a outros bens.

SEÇÃO IV

DA CONVERSÃO DA UNIÃO ESTÁVEL EM CASAMENTO

Art. 259. Os conviventes podem, de comum acordo e a qualquer tempo, converter a união estável em casamento.

Art. 260. O pedido será formulado ao Oficial do Registro Civil das Pessoas Naturais onde residam, devendo os conviventes:

I - comprovar que não estão impedidos de casar;

II - indicar o termo inicial da união;

III - arrolar os bens comuns;

IV - declinar o regime de bens;

$\mathrm{V}$ - apresentar as provas da existência da união estável.

Art. 261. Lavrada a escritura, deverá o tabelião enviar certidão ao Registro Civil em que ocorreu o casamento, para averbação.

$\S 1 .^{\circ}$ A certidão do divórcio deverá ser averbada no registro de imóvel onde se situam os bens e nos registros relativos a outros bens.

$\S 2 .^{\circ} \mathrm{O}$ envio da certidão aos respectivos registros poderá ser levado a efeito por meio eletrônico.

Art. 262. A conversão somente terá efeito perante terceiros após ser registrada no registro civil.

SEÇÃO V

DA ALTERAÇÃO DO REGIME DE BENS

Art. 263. A alteração consensual do regime dos bens pode ser formalizada por escritura pública, sem prejuízo do direito de terceiros. 
Art. 264. A alteração deve ser averbada na certidão de casamento e no registro de imóveis dos bens do casal.

Art. 265. Caso os cônjuges, ou apenas um deles, seja empresário, a alteração deve ser averbada na Junta Comercial e no registro público de empresas mercantis.

Art. 266. A alteração só produz efeito perante terceiros após a averbação no registro imobiliário e demais registros relativos a outros bens.

TÍTULO VII

\section{DAS DISPOSIÇÕES FINAIS E TRANSITÓRIAS}

Art. 267. É ineficaz qualquer ato, fato ou negócio jurídico que contrariar os princípios estabelecidos na Constituição Federal, em tratados ou convenções internacionais das quais seja o Brasil signatário e neste Estatuto.

Art. 268. Todos os tratados e convenções internacionais que assegurem direitos e garantias fundamentais de proteção aos integrantes da entidade familiar têm primazia na aplicação do presente Estatuto.

Art. 269. Todas as remissões feitas ao Código Civil, que expressa ou tacitamente foram revogadas por este Estatuto, consideram-se feitas às disposições deste Estatuto.

Art. 270. A existência e a validade dos atos, fatos e negócios jurídicos, constituídos antes da entrada em vigor deste Estatuto, obedecem ao disposto na Lei n. 10.406, de 10 de janeiro de 2002, e nas leis anteriores, mas os seus efeitos, produzidos após a vigência deste Estatuto, aos preceitos dele se subordinam.

Art. 271. Salvo disposição em contrário deste Estatuto, mantém-se a aplicação das leis especiais anteriores, naquilo que não conflitarem com regras ou princípios nele estabelecidos ou dele inferidos.

Art. 272. Até que por outra forma se disciplinem, continuam em vigor as disposições de natureza processual, administrativa ou penal, constantes de leis cujos preceitos ou princípios se coadunem com este Estatuto.

Art. 273. Este Estatuto entrará em vigor após um ano da data de sua publicação oficial.

Art. 274. Revogam-se o Livro IV - Do Direito de Família

(arts. 1.511 a 1.783) da Lei n. 10.406, de 10 de janeiro de 2002 (Código Civil), os arts. 732 a $745 ; 852$ a 854; 877 e $878 ; 888$, II e III; 1.120 a 1.124-A da Lei n. 5.869 de 11 de janeiro de 1973 (Código de Processo Civil), o Decreto-Lei n. 3.200, de 19 de abril de 1941, a Lei n. 5.478, de 25 de julho de 1968, os arts. 70 a 76 da Lei n. 
6.015, de 31 de dezembro de 1973, a Lei n. 6.515, de 26 de dezembro de 1977 e a Lei n. 8.560, de 29 de dezembro de 1992.

\section{JUSTIFICAÇÃO}

É com grande satisfação que oferecemos à sociedade este Estatuto das Famílias. Tal proposta é resultado da luta e esforço de todos os militantes da área de Direito de Família, consolidada pela Doutrina e Jurisprudência pátria e no entendimento de que a boa Lei é aquela que consagra uma prática já adotada pela sociedade. O Livro de Direito de Família do Código Civil de 2002 foi concebido pela Comissão coordenada por Miguel Reale no final dos anos 60 e início dos anos 70 do século passado, antes das grandes mudanças legislativas sobre a matéria, nos países ocidentais, e do advento da Constituição de 1988. O paradigma era o mesmo: família patriarcal, apenas constituída pelo casamento; desigualdade dos cônjuges e dos filhos; discriminação a partir da legitimidade da família e dos filhos; subsistência dos poderes marital e paternal. A partir da Constituição de 1988, operou-se verdadeira revolução copernicana, inaugurando-se paradigma familiar inteiramente remodelado, segundo as mudanças operadas na sociedade brasileira, fundada nos seguintes pilares: comunhão de vida consolidada na afetividade e não no poder marital ou paternal; igualdade de direitos e deveres entre os cônjuges; liberdade de constituição, desenvolvimento e extinção das entidades familiares; igualdade dos filhos de origem biológica ou socioafetiva; garantia de dignidade das pessoas humanas que a integram, inclusive a criança, o adolescente e o idoso. Nenhum ramo do Direito foi tão profundamente modificado quanto o Direito de Família ocidental, nas três últimas décadas do século XX. Durante a tramitação do projeto do Código Civil no Congresso Nacional, após a Constituição de 1988, o Senado Federal promoveu esforço hercúleo para adaptar o texto - antes dela elaborado - às suas diretrizes. Todavia, o esforço resultou frustrante, pois não se poderia adaptar institutos que apenas faziam sentido como expressão do paradigma familiar anterior à nova realidade, exigente de princípios, categorias e institutos jurídicos diferentes. A doutrina especializada demonstrou à saciedade a inadequação da aparente nova roupagem normativa, que tem gerado intensas controvérsias e dificuldades em sua aplicação. Ciente desse quadro, consultei o Instituto Brasileiro de Direito de Família - IBDFAM, entidade que congrega cerca de 4.000 especialistas, profissionais e estudiosos do Direito de Família, e que também tenho a honra de integrar, se uma 
revisão sistemática do Livro IV da Parte Especial do Código Civil teria o condão de superar os problemas que criou. Após vários meses de debates, a comissão científica do IBDFAM, ouvindo os membros associados, concluiu que, mais do que uma revisão, seria necessário um estatuto autônomo, desmembrado do Código Civil, até porque seria imprescindível associar as normas de Direito Material com as normas especiais de Direito Processual. Não é mais possível tratar questões visceralmente pessoais da vida familiar, perpassadas por sentimentos, valendo-se das mesmas normas que regulam as questões patrimoniais, como propriedades, contratos e demais obrigações. Essa dificuldade, inerente às peculiaridades das relações familiares, tem estimulado muitos países a editarem códigos ou leis autônomas dos direitos das famílias. Outra razão a recomendar a autonomia legal da matéria é o grande número de projetos de leis específicos, que tramitam nas duas Casas Legislativas, propondo alterações ao Livro de Direito de Família do Código Civil, alguns modificando radicalmente o sentido e o alcance das normais atuais. Uma lei que provoca a demanda por tantas mudanças, em tão pouco tempo de vigência, não pode ser considerada adequada. Eis porque, também convencido dessas razões, submeto à apreciação dos ilustres Pares o presente Projeto de Lei, como Estatuto das Famílias, traduzindo os valores que estão consagrados nos princípios emergentes dos artigos 226 a 230 da Constituição Federal. A denominação utilizada - "Estatuto das Famílias" - contempla melhor a opção constitucional de proteção das variadas entidades familiares. No passado, apenas a família constituída pelo casamento portanto única - era objeto do Direito de Família. Optou-se por uma linguagem mais acessível à pessoa comum do povo, destinatário maior dessas normas, evitando-se termos excessivamente técnicos ou em desuso. Assim, por exemplo, em vez de dizer "idade núbil" alude-se a casamento da pessoa relativamente incapaz. Entidades familiares - O Código Civil é iniciado com o casamento, tal qual o Código de 1916, indiferente ao comando constitucional de tutela das demais entidades. O Estatuto das Famílias, diferentemente, distribui as matérias, dedicando o Título I às normas e princípios gerais aplicáveis às famílias e às pessoas que as integram. Acompanhando os recentes Códigos e leis gerais de Direito de Família, o Estatuto das Famílias enuncia em seguida as regras gerais sobre as relações de parentesco. O título destinado às entidades familiares estabelece diretrizes comuns a todas elas, após o que passa a tratar de cada uma. Além do casamento, o Estatuto das Famílias sistematiza as regras especiais da união estável, da união homoafetiva e da família 
parental, na qual se inclui a família monoparental. A Constituição atribui a todas as entidades familiares a mesma dignidade e igual merecimento de tutela, sem hierarquia entre elas. Casamento, regime de bens e divórcio - O Capítulo do casamento é o mais extenso, dada a importância que a sociedade brasileira a ele destina, sistematizando todas as matérias anexas ou conexas, de modo seqüenciado: existência, validade, eficácia, regime de bens, divórcio e separação. A separação dessas matérias feita pelo Código Civil, em direitos pessoais e direitos patrimoniais, não foi bem recebida pela doutrina especializada, dada a interconexão entre ele e o papel instrumental dos segundos. Além do mais, considerando que cada cidadão brasileiro integra ao menos uma família, a lei deve ser compreensível pelo homem comum do povo e não contemplar discutível opção doutrinária. Foram suprimidas as causas suspensivas do casamento, previstas no Código Civil, porque não suspendem o casamento, representando, ao contrário, restrições à liberdade de escolha de regime de bens. Os impedimentos aos casamentos foram atualizados aos valores sociais atuais, com redação mais clara. Simplificaram-se as exigências para a celebração do casamento, civil ou religioso, e para o registro público, com maior atenção aos momentos de sua eficácia. Procurou-se valorizar a atuação do juiz de paz na celebração do casamento civil. Suprimiu-se o regime de bens de participação final nos aquestos, introduzido pelo Código Civil, em virtude de não encontrar nenhuma raiz na cultura brasileira e por transformar os cônjuges em sócios de ganhos futuros reais ou contábeis, potencializando litígios. Mantiveram-se, assim, os regimes de comunhão parcial, comunhão universal e separação total. Por seu caráter discriminatório e atentatório à dignidade dos cônjuges, também foi suprimido o regime de separação obrigatório, que a Súmula 377 do Supremo Tribuna Federal (STF) tinha praticamente convertido em regime de comunhão parcial. Definiu-se, com mais clareza, quais os bens ou valores que estão excluídos da comunhão parcial, tendo em vista as controvérsias jurisprudenciais e a prática de sonegação de bens que devem ingressar na comunhão. Privilegiou-se o divórcio, como meio mais adequado para assegurar a paz dos que não mais desejam continuar casados, definindo em regras simples e compreensíveis os requisitos para alcançá-lo. Evitou-se, tanto no divórcio quanto na separação, a interferência do Estado na intimidade do casal, ficando vedada a investigação das causas da separação, que não devem ser objeto de publicidade. O que importa é assegurar-se o modo de guarda dos filhos, no melhor interesse destes, a fixação ou dispensa dos alimentos entre os cônjuges, a obrigação 
alimentar do não guardião em relação aos filhos comuns, a manutenção ou mudança do nome de família e a partilha dos bens comuns. A separação, o divórcio e a mudança de regime de bens extrajudiciais, mediante escritura pública, receberam regulamentação mais detida, quanto à sua facilitação, seus efeitos e à preservação dos interesses dos cônjuges e de terceiros. União estável - O Estatuto das Famílias procurou eliminar todas as assimetrias que o Código Civil ostenta em relação à união estável, no que concerne aos direitos e deveres comuns dos conviventes, em relação aos idênticos direitos e deveres dos cônjuges. Quando a Constituição se dirige ao legislador para que facilite a conversão da união estável para o casamento, não institui aquela em estágio provisório do segundo. Ao contrário, a Constituição assegura a liberdade dos conviventes de permanecerem em união estável ou a converterem em casamento. Da mesma maneira, há a liberdade de os cônjuges se divorciarem e constituírem em seguida, ou tempos depois, união estável entre eles, se não desejarem casar novamente. Uniformizaram-se os deveres dos conviventes, entre si, em relação aos deveres conjugais. Optou-se por determinar que a união estável constitui estado civil de "convivente", retomando-se a denominação inaugurada com a Lei $n^{\circ}$ 9.263/96, que parece alcançar melhor a significação de casal que convive em união afetiva, em vez de companheiro, preferida pelo Código Civil. Por outro lado, o convivente nem é solteiro nem casado, devendo explicitar que seu estado civil é próprio, inclusive para proteção de interesses de terceiros com quem contrai dívidas, relativamente ao regime dos bens que por estas responderão. União homoafetiva - $\mathrm{O}$ estágio cultural que a sociedade brasileira vive, na atualidade, encaminha-se para o pleno reconhecimento da união homoafetiva. A norma do art. 226 da Constituição é de inclusão - diferentemente das normas de exclusão das Constituições pré-1988 -, abrigando generosamente todas as formas de convivência existentes na sociedade. A explicitação do casamento, da união estável e da família monoparental não exclui as demais que se constituem como comunhão de vida afetiva, de modo público e contínuo. Em momento algum, a Constituição veda o relacionamento de pessoas do mesmo sexo. A jurisprudência brasileira tem procurado preencher o vazio normativo infraconstitucional, atribuindo efeitos às relações entre essas pessoas. Ignorar essa realidade é negar direitos às minorias, incompatível com o Estado Democrático. Tratar essas relações como meras sociedades de fato, como se as pessoas fossem sócios de uma sociedade de fins lucrativos, é violência que se perpetra contra o princípio da dignidade das pessoas humanas, consagrado no art. $1^{\circ}$, inciso III da 
Constituição. Se esses cidadãos brasileiros trabalham, pagam impostos, contribuem para o progresso do País, é inconcebível interditar-lhes direitos assegurados a todos, em razão de suas orientações sexuais. Filiação - A filiação é tratada de modo igualitário, pouco importando a origem consangüínea ou socioafetiva (adoção, posse de estado de filho ou inseminação artificial heteróloga). Almeja-se descortinar os paradigmas parentais, materno-filiais e paterno-filiais que podem apreender, no plano jurídico, a família como realidade socioafetiva, coerente com o tempo e o espaço do Brasil atual, recebendo a incidência dos princípios norteadores da superação de dogmas preconceituosos. Procurou-se distinguir com clareza, para se evitar as contradições jurisprudenciais reinantes nesta matéria, o que é dever de registro do nascimento, reconhecimento voluntário do filho, investigação judicial de paternidade ou maternidade e impugnação da paternidade e da maternidade ou da filiação. Nenhuma impugnação deve prevalecer quando se constatar a existência de posse de estado da filiação, consolidada na convivência familiar duradoura. A presunção da paternidade e da maternidade, antes fundada na necessidade de se apurar a legitimidade do filho, passou a ser radicada na convivência dos pais durante a concepção, sejam eles casados ou não. Abandonou-se a concepção de poder dos pais sobre os filhos para a de autoridade parental que, mais do que mudança de nomenclatura, é a viragem para a afirmação do múnus, no melhor interesse dos filhos, além de contemplar a solidariedade que deve presidir as relações entre pais e filhos. O direito de visita, já abandonado pelas legislações recentes, é substituído pelo direito à convivência do pai não-guardião em relação ao filho e deste em relação àquele. Os pais se separam entre si, mas não dos filhos, que devem ter direito assegurado de contato e convivência com ambos. Também é estimulada, sempre que possível, a guarda compartilhada, no melhor interesse dos filhos. A tutela das crianças e adolescentes teve suas regras simplificadas no Estatuto das Famílias, procurando harmonizá-las com as constantes no Estatuto da Criança e do Adolescente (ECA), eliminando-se requisitos que se revelaram inúteis ou inibidores desse relevante múnus. Quanto à adoção, e para se evitar as colisões com o modelo sistematizado no Estatuto da Criança e do Adolescente ou o paralelismo legal hoje existente, ficaram enunciados neste projeto de Estatuto das Famílias as normas e princípios gerais, disciplinando-se a adoção de maiores e remetendo-se ao ECA a adoção de crianças e adolescentes. Alimentos - Os alimentos tiveram como matriz a máxima realização da solidariedade familiar, eliminando-se os resquícios de causas 
ou condições discriminatórias. Manteve-se a obrigação alimentar, infinitamente, entre os parentes em linha reta e entre irmãos. Limitou-se em 25 anos a presunção de necessidade alimentar do filho, quando em formação educacional. A partir daí exigese a comprovação da necessidade. Esclareceu-se que a obrigação alimentar dos parentes em grau maior, por exemplo, dos avós em relação aos netos, é complementar, se os pais não puderem atendê-la integralmente. Foi limitada a irrenunciabilidade dos alimentos à obrigação decorrente do parentesco, bem como se aboliu a vetusta idéia de valorar a culpa no rompimento das relações afetivas, eis que nada agrega ao Direito Familiar. Bem de família - O Estatuto das Famílias não mais cuida do chamado bem de família voluntário ou convencional, de escassa utilidade ou utilização na sociedade brasileira, principalmente por suas exigências formais e por gerar oportunidades de fraudes a terceiros. Concluiu-se que a experiência vitoriosa do bem de família legal, introduzido pela Lei $\mathrm{n}^{\circ}$ 8.009/90, consulta suficientemente o interesse da família em preservar da impenhorabilidade o imóvel onde reside, sem qualquer necessidade de ato público prévio, e com adequada preservação dos interesses dos credores. Curatela - A continuidade da curatela no âmbito do Direito de Família sempre foi objeto de controvérsias doutrinárias. Optouse por mantê-la assim, tendo em vistas que as interferências com as relações familiares são em maior grau. Processo, procedimentos e revogações - O Estatuto das Famílias está dividido em duas grandes partes, uma de Direito Material e outra de Direito Processual. Tal providência evita a confusão, ainda existente no Código Civil, entre o que é constituição, modificação e extinção de direitos e deveres, de um lado, e os modos de sua tutela, principalmente jurisdicional, de outro. Na parte destinada ao processo e aos procedimentos, sistematizaram-se os procedimentos dispersos no próprio Código Civil, no Código de Processo Civil e em leis especiais, que restarão ab-rogados ou derrogados. Por exemplo, a habilitação para o casamento, que o Código Civil trata em minúcias, é procedimento e não Direito Material. Este Estatuto considera o processo como procedimento em contraditório. Na ausência de contraditório, tem-se apenas procedimento, em substituição à antiga jurisdição graciosa ou voluntária. As regras de processo e de procedimentos, nas relações de família, não podem ser as mesmas do processo que envolvem disputas patrimoniais, porque os conflitos familiares exigem resposta diferenciada, mais rápida e menos formalizada, como ocorreu com o Estatuto da Criança e do Adolescente - ECA. Daí a necessidade de concretizar os princípios da oralidade, celeridade, simplicidade, 
informalidade e economia processual, além de preferência no julgamento dos tribunais. O Estatuto das Famílias privilegia a conciliação, a ampla utilização de equipes multidisciplinares e o estímulo à mediação extrajudicial. Por fim, são indicadas as leis e demais normas jurídicas que ficam revogadas expressamente conforme a Lei Complementar $\mathrm{n}^{\mathrm{o}}$ 95, de 26 de fevereiro de 1998 e Lei Complementar $\mathrm{n}^{\mathrm{o}} 107$, de 26 de abril de 2001. A falta de revogação expressa de antigas leis sobre relações de família tem levado a dúvidas, a exemplo da continuidade ou não da vigência do Decreto-Lei n ${ }^{\circ} 3.200 / 41$, apesar do Código Civil de 2002. Em face de todo o exposto, conto com o decisivo apoio dos ilustres Pares para a aprovação deste importante Projeto de Lei, que dispõe sobre o Estatuto das Famílias. Sala das Sessões, em 25 de outubro de 2007. Deputado Sérgio Barradas Carneiro. 


\section{Projeto Walter Brito Neto}

PROJETO DE LEI No 3323 , DE 2008

do Deputado Walter Brito Neto

Altera a Lei 8069, de 13 de julho de 1990, Estatuto da Criança e do Adolescente, para vedar a adoção por casal do mesmo sexo.

O Congresso Nacional decreta:

Art. 1. ${ }^{\circ}$ Esta Lei acrescenta parágrafo a Lei 8069, de 13 de julho de 1990 , Estatuto da Criança e do Adolescente, para vedar a adoção por casais do mesmo sexo.

Art. 2. ${ }^{\circ}$ Acrescente ao art. 39 da Lei 8069, de 13 de julho de 1990 , Estatuto da Criança e do Adolescente, o parágrafo seguinte:

"Art. 39

$\S 1^{\circ}$. É vedada a adoção por procuração.

$\S 2^{\circ}$. É vedada a adoção por casal do mesmo sexo." (AC)

Art. 3. ${ }^{\circ}$ Esta lei entra em vigor 60 (sessenta) dias após a data de sua publicação.

\section{JUSTIFICAÇÃO}

A luta homoafetiva pelo seu espaço na sociedade vem criando debates e sugerindo novos conceitos. A constante transformação do paradigma familiar ainda não conseguiu quebrar os tabus, preconceitos e principalmente entendimentos religiosos e jurídicos que pudessem absorver tal polêmica, no entanto, com objetivo de reforçar o que já está estabelecido no nosso ordenamento jurídico, é que apresento esta proposição. De acordo com a sociedade e a Constituição Brasileira o modelo de família é constituído por um homem e uma mulher, seja por união estável ou por casamento, a fim de formar uma família. No entanto, os "casais" do mesmo sexo afirmam que para eles o que realmente interessa é o amor de um para com o outro, ao passo de deixar de lado a sistemática da formação familiar. Neste sentido, dentro do sistema jurídico não existe nenhuma censura, em razão da opção sexual. Por outro lado, existem empecilhos para adoção por parte de casal do mesmo sexo, conforme dispositivos da Constituição Federal e do Código Civil Brasileiro, a saber: Art. 226 § $3^{\circ}$, da Constituição Federal: "Para efeito da proteção do Estado, é reconhecida a 
união estável entre o homem e a mulher como entidade familiar, devendo a lei facilitar sua conversão em casamento."; e Art.1.622 do Código Civil: "Ninguém pode ser adotado por duas pessoas, salvo se forem marido e mulher." Como se observa, a Constituição acrescenta como entidade familiar, além do casamento civil, a união estável entre homem e mulher. De forma objetiva, o Código Civil de 2002 manteve o texto no qual não permite a adoção por aqueles. Há de se observar também os dogmas religiosos. É sabido que o Estado é laico, no entanto, não se pode falar que ele é ateu. Hoje, mais de $90 \%$ da população brasileira é Cristã, ou seja, além de garantir o direito da minoria temos o dever de respeitar o direito da maioria. Por outro lado, não podemos esquecer a relação psicológica envolvida diretamente ao adotado, pois há uma grande discussão entre psicólogos e psiquiatras sobre o comportamento dessa criança ao ser inserida em uma família de casal do mesmo sexo. Seria possível responder a tais questionamentos: 1. A ausência de referência de ambos os gêneros tornaria confusa a identidade sexual da criança? 2. A criança poderia ser alvo de repúdio, chacotas, discriminação no meio que vier a freqüentar? 3. Diante do tabu da sociedade, muitos "casais" do mesmo sexo não se expõem, dificultando assim a visualização do contexto familiar. Em razão desta situação, a criança absorveria como algo natural chamar os pais do mesmo sexo diferenciando cada um por PAI E MÃE? Assim, tendo em vista a relevância deste Projeto de Lei para a proteção da família, esperamos contar com o apoio de nossos Pares nesta Casa para a célere aprovação desta proposta. Sala das Sessões, em 23 de abril de 2008. Deputado WALTER BRITO NETO. 


\section{Projeto Olavo Calheiros}

PROJETO DE LEI No 4508, DE 2008

do Deputado Federal Olavo Calheiros

Proíbe a adoção por homossexual.

\section{O Congresso Nacional decreta:}

Art. $1^{\mathrm{o}}$ Esta Lei tem por finalidade vedar a adoção por homossexuais.

Art. $2^{\circ}$. O parágrafo único do art. 1.618 da Lei n. ${ }^{\circ}$ 10.406, de 10 de janeiro de 2002, passa a vigorar com a seguinte redação:

'Art. 1.618

Parágrafo único. A adoção poderá ser formalizada, apenas por casal que tenha completado dezoito anos de idade, comprovado o casamento oficial e a estabilidade da família, sendo vedada a adoção por homossexual." (NR)

Art. $3^{\circ}$. Esta lei entra em vigor na data de sua publicação.

\section{JUSTIFICAÇÃO}

O objetivo desta lei é resguardar a criança adotada, que não poderá ser exposta a situação que possa interferir na sua formação. Toda criança deve ter direito a um lar constituído de forma regular, de acordo com os padrões da natureza. A adoção por casais homossexuais pode expor a criança a sérios constrangimentos. Uma criança, cujos pais adotivos mantenham um relacionamento homoafetivo, terá grandes dificuldades em explicar aos seus amigos e colegas de escola, por exemplo, porque tem dois pais, sem nenhuma mãe, ou duas mães, sem nenhum pai. Em épocas festivas, como dia das mães ou dia dos pais, essa criança sofrerá constrangimentos marcantes pela ausência de um pai ou de uma mãe. Até mesmo a compreensão por parte da criança quanto a essa realidade afigurar-se-á difícil e distorcida no que tange à composição do núcleo familiar. É dever do Estado por a salvo a criança e o adolescente de qualquer situação que possa causar-lhes embaraços, vexames e constrangimentos. A educação e a formação de crianças e adolescentes devem ser processadas em ambiente completamente adequado e favorável a um bom desenvolvimento intelectual, psicológico, moral e espiritual. Por essa razão, o ordenamento jurídico, adequando-se aos preceitos constitucionais deve resguardar os 
jovens de qualquer exposição que possa comprometer-lhes a formação e o desenvolvimento. Desse modo, apresento este Projeto vedando expressamente a adoção por casais que vivam em união homoafetiva, para o qual conto com o apoio dos ilustres Pares. Sala das Sessões, em de de 2008. Deputado Olavo Calheiros. 


\section{BIBLIOGRAFIA}

AMORIM, Sebastião Luiz; OLIVEIRA, Euclides de. Concubinato, companheiros: novos rumos, in Tereza Arruda Alvim (coord.), Repertório de jurisprudência e doutrina sobre Direito de Família - aspectos constitucionais, civis e processuais, vol. 2, São Paulo, RT, 1995, p. 71-100.

AUBRY e RAU, Cours de Droit Civil Français, t. IX, Paris, Marchal et Godde, 1917.

AZEVEDO, Álvaro Villaça. Do concubinato ao casamento de fato, Belém, CEJUP, 1986.

. Comentários ao Código Civil - artigos 1711 a 1783, vol. 19, São Paulo, Saraiva, 2003.

AZEVEDO, Antonio Junqueira de. O Direito Civil tende a desaparecer?, in Revista dos Tribunais, vol. 472, São Paulo, fev. 1975, p. 15-21.

. Retrocesso no Direito de Família, in Revista da Faculdade de Direito da Universidade de São Paulo, vol. 93, São Paulo, 1998, p. 111-114.

. L'ordre public dans les relations de famille, in Maria Helena Diniz (coord.), Atualidades jurídicas, São Paulo, Saraiva, 1999, p. 51-59.

. O Direito ontem e hoje. Crítica ao neopositivismo constitucional e à insuficiência dos direitos humanos, in Revista do Advogado, ano XXVIII, no 99, São Paulo, AASP, setembro de 2008, p. 07-14.

AZEVEDO, Tupinambá Pinto. Casamento: instituição em xeque. In: SOUZA, Ivone M. C. Coelho de. Casamento: uma escuta além do judiciário. Florianópolis: Voxlegem, 2006, p. 21-44.

BARBOSA, Rui. Oração aos moços; edição popular anotada por Adriano da Gama Kury, 5 a . ed., Rio de Janeiro, Fundação Casa de Rui Barbosa, 1997.

BARROS, Sérgio Resende de. A monetarização do afeto, in Revista do Instituto de Pesquisas e Estudos da Instituição Toledo de Ensino, Bauru, n. 33, dez. 2001 a mar. 2002, p. 465.

- Direitos humanos da família: dos fundamentais aos operacionais. In: GROENINGA, Giselle Câmara; PEREIRA, Rodrigo da Cunha (coords.). Direito de família e psicanálise. São Paulo: Imago, 2003, p. 143-154.

- Direitos Humanos e Direito de Família, disponível [on line] in http://www.srbarros.com.br/artigos.php? TextID=85 [26-01-2004]. 
BELLONI, Fabio. A referência que se tem de família, painel apresentado no $\mathrm{I}^{\circ}$ Congresso Latino-americano da Psicologia, São Paulo, 2005, in http:// www.ulapsi.org /cdrom lespanhol /autor4.php? uid=929\&tipo $=P E S Q \&$ codigo $=460$ [12/03/2009].

BEVILÁQUA, Clóvis, Código Civil dos Estados Unidos dos Brasil comentado, vol. 2, $12^{\text {a }}$ ed., Rio de Janeiro, F. Alves, 1960.

BITTAR, Carlos Alberto. Direito de família. Rio de Janeiro: Forense Universitária, 1991.

BOBBIO, Norberto. O Futuro da Democracia; uma defesa das regras do jogo. Rio de Janeiro: Paz e Terra, 1986.

- A teoria do ordenamento jurídico. Trad. Maria Celeste Cordeiro Leite dos Santos. 10. ed. Brasília: UnB, 1997.

BOEIRA, José Bernardo Ramos. Investigação de paternidade - Posse de estado de filho - Paternidade socioafetiva. Porto Alegre: Livraria do Advogado, 1999.

. Filiação e solução de conflitos de paternidade. In: FREITAS, Douglas Phillips (coord.). Curso de direito de família. Florianópolis: Vox Legem, 2004, p. 133-156.

BONAVIDES, Paulo. Curso de direito constitucional. 8. ed. São Paulo: Malheiros, 1999.

BORRILLO, Daniel. O indivíduo homossexual, o casal de mesmo sexo e as famílias homoparentais: análise da realidade jurídica francesa no contexto internacional, in Revista da Faculdade de Direito de Campos, Ano VI, n. 7, dezembro de 2005, p. 63112.

CALANDRA, Henrique Nelson. Repertório de jurisprudência e doutrina sobre direito de família. São Paulo: Revista dos Tribunais, 1995. v. 2.

CAMPOS, Wania Andréa;. FIGUEIREDO, Luciana C. Duarte de. O direito à busca da origem genética na relação familiar socioafetiva. In: PEREIRA, Rodrigo da Cunha; PEREIRA, Tânia da Silva (coords.). A ética da convivência familiar e a sua efetividade no cotidiano dos tribunais. Rio de Janeiro: Forense, 2006, p. 325-360.

CANEZIN, Claudete Carvalho. Da guarda compartilhada em oposição à guarda unilateral. In Revista Brasileira de Direito de Família, Porto Alegre: IBDFAM/Síntese, n. 28, p. 5-25, fev-mar. 2005.

- A noção de poder familiar e a desconsideração do novo modelo de família nuclear. In: BARROSO, Lucas Abreu (coord.). Introdução crítica ao Código Civil. 
Rio de Janeiro: Forense, 2006, p. 463-479.

CANOTILHO, José Joaquim Gomes. Direito Constitucional e Teoria da Constituição, $3^{\text {a }}$ Ed., Almedina, 1999.

CARBONERA, Silvana Maria, O papel jurídico do afeto nas relações de família, in Luiz Edson Fachin (coord.), Repensando fundamentos do Direito Civil brasileiro contemporâneo, Rio de Janeiro, Renovar, 2000, p. 273-313.

CARBONNIER, Jean. Droit et passion du droit, Paris, Flammarion, 2001.

. Flexible droit, 10ª ed., Paris, L.G.D.J., 2001.

. La famille, l'enfant, le couple - Droit Civil, t. 2, 21 a ed., Paris, PUF, 2002.

CHAVES, Antônio. Falsidade ideológica decorrente do registro de filhos alheios como próprios - Pode a sociedade punir um ato cuja nobreza exalça?, in Revista da Faculdade de Direito, vol. LXXII, 2º Fasc., 1977, p. 87-105.

CHINELATO, Silmara Juny. Comentários ao Código Civil - artigos 1591 a 1710, vol. 18, São Paulo, Saraiva, 2004.

COLOMBET, Claude, La famille - Collection Droit Fondamental - Droit Civil, $5^{\mathrm{a}}$ ed., Paris, PUF, 1997.

CORMAN, Louis. O teste do desenho de família, Mestre Jou, São Paulo, 1979.

CORTIANO JÚNIOR, Erouths, O Direito de Família no projeto do Código Civil, in Tereza Arruda Alvim Wambier e Eduardo de Oliveira Leite (coord.), Repertório de doutrina sobre Direito de Família - aspectos constitucionais, civis e processuais, vol. 4, São Paulo, RT, 1999, p. 222-243.

COSTA, Maria Isabel Pereira da. Família: do autoritarismo ao afeto. Revista Brasileira de Direito de Família, Porto Alegre: IBDFAM/Síntese, n. 32, p. 20-39, out.-nov. 2005.

DELENSKI, Julie Cristine. O novo direito da filiação. São Paulo: Dialética, 1997.

DIAS, Maria Berenice. Bem feito! Quem manda ser mulher?, disponível [on line] in http://www.mundolegal.com.br/?FuseAction=Artigo_Detalhar\&did=26674 [06/01/ 2009].

- Filiação homoafetiva, in Afeto, Ética, Família e o Novo Código Civil Brasileiro - Anais do IV Congresso Brasileiro de Direito de Família, Del Rey, Belo Horizonte, 2004, p. 393-397.

. Manual de Direito das Famílias. 4a ed. ver. e ampl., São Paulo, RT, 2007.

DINIZ, Maria Helena. Curso de direito civil brasileiro. 17. ed. São Paulo: Saraiva, 2002. $5 \mathrm{v}$. 
DIREITO, Carlos Alberto Menezes. Da união estável no novo Código Civil. In: BASTOS, Eliene Ferreira; SOUZA, Asiel Henrique de (coords.). Família e jurisdição. Belo Horizonte: Del Rey, 2005, p. 45-64.

ELIAS, Roberto João, Pátrio Poder - Guarda dos Filhos e Direito de Visita, São Paulo, Saraiva, 1999.

FACCHINI NETO, Eugênio. "E o juiz não é só de direito ... " (ou "A função jurisdicional e a subjetividade"). In: ZIMERMAN, David; COLTRO, Antônio Carlos Mathias (coords.). Aspectos psicológicos na prática jurídica. Campinas: Millennium, 2002, p. 303-317.

FACHIN, Luiz Edson. Elementos críticos do direito de família - Curso de Direito Civil. Rio de Janeiro: Renovar, 1999.

. O Código Civil e o desassossego da filiação, in Carta Forense, São Paulo, ed. n. 57, fev/2008, p. 48.

FERNANDES, Taísa Ribeiro. Uniões homossexuais e seus efeitos jurídicos. São Paulo: Método, 2004.

FERNANDES, Tycho Brahe. A reprodução assistida em face da bioética e do biodireito: aspectos do direito de família e do direito das sucessões. Florianópolis: Diploma Legal, 2000.

FERREIRA, Aurélio Buarque de Holanda. Dicionário Aurélio, versão eletrônica 5.0, São Paulo, Positivo, 2009.

FERRY, Luc. Famílias, amo vocês: política e vida privada na era da globalização, trad. Jorge Bastos, Rio de Janeiro, Objetiva, 2008.

. Aprendendo a viver: filosofia para os novos tempos, trad. Vera Lúcia dos Reis, Rio de Janeiro, Objetiva, 2007.

FIUZA, César Augusto de Castro. Diretrizes hermenêuticas do direito de família. In: PEREIRA, Rodrigo da Cunha (coord.). Anais do IV Congresso Brasileiro de Direito de Família. Família e dignidade humana. Belo Horizonte: IBDFAM, 2006, p. 223240.

FONSECA, Antonio Cezar Lima da. O Código Civil e o novo direito de família. Porto Alegre: Livraria do Advogado, 2004.

GARBIN, Rosana Broglio. Famílias monoparentais: da visão singular ao modelo plural. A teoria e a prática dos saberes do cotidiano. Porto Alegre: AJURIS, 2005.

GARCIA, Edinês Maria Sormani. Direito de família: princípio da dignidade da pessoa humana. Leme: Editora de Direito, 2003. 
GOMES, Orlando, Direito de Família, 14 a ed., atualizada por Humberto Theodoro Júnior, Rio de Janeiro, Forense, 2002.

GONÇALVES, Maria Dinair Acosta. Proteção integral: paradigma multidisciplinar do direito pós-moderno. Porto Alegre: Alcance, 2002.

GORDILHO, Heron José de Santana. Direito Animal: a legitimidade de ser parte. Jornal Carta Forense, São Paulo, ed. 70, mar. 2009, p. 32-33.

GRISARD FILHO, Waldyr. Guarda compartilhada: um novo modelo de responsabilidade parental, São Paulo: Revista dos Tribunais, 2000.

GROENINGA, Giselle Câmara. Entre subjetividade e objetividade, In: PEREIRA, Rodrigo da Cunha (coords.). Direito de família e psicanálise. São Paulo: Imago, 2003, p. 125-142.

GUIMARÃES, Giovane Serra Azul, Adoção, Tutela e Guarda, São Paulo, Juarez de Oliveira, 2000.

HESKETH, Avelina Imbiriba (org.). Cidadania da mulher: uma questão de justiça. Brasília: OAB Ed., 2003.

HESSE, Konrad. A força normativa da constituição. trad. Gilmar Ferreira Mendes. Porto Alegre: Fabris, 1991.

HIRONAKA, Giselda Maria Fernandes Novaes. Família e casamento em evolução. Revista Brasileira de Direito de Família, Porto Alegre: IBDFAM/Síntese, n. 1, p. 717, abr.-jun, 1999.

KANT, Immanuel. Fundamentação da metafísica dos costumes e outros escritos, trad. Leopoldo Holzbach, São Paulo, Martin Claret, 2003.

LAGRASTA NETO, Caetano. Direito de família. São Paulo: Malheiros, 2000.

LAURENT, F., Principes du Droit Civil français, vol. 4, 3ª ed., Bruxelas, BruylantChristophe \& Cie., 1893.

LÔBO, Paulo Luiz Netto. A repersonalização das relações de família, in Revista Brasileira de Direito de Família, Ano VI, n. 24, Porto Alegre, Síntese, jun-jul 2004, p. 136-156.

Famílias. São Paulo: Saraiva, 2008.

LOPES, José Reinaldo De Lima. O Direito na História - lições introdutórias, São Paulo, Max Limonad, 2000.

LORENZETTI, Ricardo Luis. Fundamentos do Direito Privado, São Paulo, RT, 1998.

MADALENO, Rolf Hanssen. Direito de família: aspectos polêmicos. $2^{\mathrm{a}}$. ed. Porto 
Alegre: Livraria do Advogado, 1999. . Novas perspectivas da família. Porto Alegre: Livraria do Advogado, 2000. MAGALHÃES, Rui Ribeiro de. Direito de família no novo Código Civil brasileiro. São Paulo: Juarez de Oliveira, 2002.

MALUF, Carlos Alberto Dabus, A transação no Direito Civil e no Processo Civil, $2^{\mathrm{a}}$ ed., São Paulo, Saraiva, 1999.

MARKY, Thomas, Curso elementar de Direito Romano, $2^{\mathrm{a}}$ ed., São Paulo, Resenha Tributária, 1974.

MATHIEU, Bertrand. Relatório na XV Mesa Redonda Internacional de Aix-enProvence, sobre o tema "Constitution et sécurité-juridique”, set/1999, in Annuaire Internacional de Justice Constitutionnelle, XV, 1999, Paris, Economica, 2000, p. 155-156.

MATOS, Ana Carla Harmatiuk. As famílias não fundadas no casamento e a condição feminina. Rio de Janeiro: Renovar, 2000.

. União entre pessoas do mesmo sexo; aspectos jurídicos e sociais. Belo Horizonte: Del Rey, 2004.

NALINI, José Renato. A questão da ética. Estamos atravessando uma crise? In: ZIMERMAN, David; COLTRO, Antônio Carlos Mathias (coords.). Aspectos psicológicos na prática jurídica. Campinas: Millennium, 2002, p. 25-33.

NAZO, Georgette Nacarato. Igualdade de direitos das relações familiares: lei e a prática no Brasil, in Cadernos Liberais - Em homenagem a Washington de Barros Monteiro, n. 95, Brasília, Instituto Tancredo Neves, 1990, p. 35-55.

. Adoção internacional: valor e importância das convenções internacionais vigentes no Brasil, in Revista da Faculdade de Direito da Universidade de São Paulo, vol. 92, São Paulo, 1997, p. 301-320.

NUNES, José Carlos Amorim de Vilhena. Guarda compartilhada - evolução do conceito dentro do novo sistema jurídico brasileiro, dissertação de mestrado FADUSP, São Paulo, 2005.

OLIVEIRA, Euclides Benedito de. União estável - Do concubinato ao casamento Antes e depois do novo Código Civil. 6. ed., São Paulo, Método, 2003.

OLIVEIRA, José Lamartine C. de; MUNIZ, Francisco José F. Direito de família. Porto Alegre: Fabris, 1990.

PEREIRA, Caio Mario da Silva. Reconhecimento de paternidade e seus efeitos, Rio de Janeiro, Forense, 1997. 
. Instituições de Direito Civil - Introdução ao Direito Civil. Teoria Geral do

Direito Civil, vol. I, atualizado por Maria Celina Bodin de Moraes, 20ª ed., Rio de Janeiro, Forense, 2004.

. Instituições de Direito Civil - Direito de família, vol. V, atualizado por

Tânia da Silva Pereira, 14ª ed., Rio de Janeiro, Forense, 2004.

PEREIRA, Lafayette Rodrigues, Direitos de Família, Rio de Janeiro, Fonseca Filho, 1910.

PEREIRA, Rodrigo da Cunha. Direito, amor e sexualidade. In: Anais do II Congresso Brasileiro de Direito de Família. A família na travessia do milênio. Belo Horizonte: IBDFAM/OAB-MG/Del. Rey, 2000, p. 53-60.

- Princípios fundamentais e norteadores para a organização jurídica da família. Belo Horizonte: Del Rey, 2006.

PEREIRA, Sérgio Gischkow. Direito de família: aspectos do casamento, sua eficácia, separação, divórcio, parentesco, filiação, união estável, tutela e curatela. Porto Alegre: Livraria do Advogado, 2007.

PERROT, Michelle. O nó e o ninho. Revista Veja 25 anos: reflexões para o futuro, São Paulo, Abril, 1993, p. 75-81.

PIOVESAN, Flávia. Direitos humanos e o direito constitucional internacional. 2. ed. São Paulo: Max Limonad, 1997. . Temas de direitos humanos. São Paulo: Max Limonad, 1998.

POLICARPO, José da Cruz. Globalização, último desafio de harmonia, in Revista Vida Católica, $\mathrm{n}^{\mathrm{o}} 21,3^{\mathrm{a}}$ série, ano VII, Lisboa, Setembro/Dezembro de 2005, tópico III, item 17.2, disponível [on line $]$ in http://www.patriarcadolisboa.pt/vidacatolica/vcnum21/3_17_Artigo_Revista_ECONOMIA.doc [10-02-09]. PONTES DE MIRANDA, Francisco Cavalcanti. Tratado das ações. São Paulo: Revista dos Tribunais, 1970. t. I.

. Tratado de direito privado, vol. 9, $3^{\mathrm{a}}$ ed., Rio de Janeiro, Max Limonad, 1947.

REALE, Miguel. O projeto do Código Civil. 2. ed. São Paulo: Saraiva, 1999.

REGAN, Tom. Jaulas vazias - encarando o desafio dos Direitos Animais, Lugano, São Paulo, 2006.

RIOS, Roger Raupp. Direitos fundamentais e orientação sexual: o direito brasileiro e a homossexualidade. In Revista CEJ do Centro de Estudos judiciários do Conselho da Justiça Federal, Brasília, n. 6, dez. 1998. 
. A homossexualidade no direito. Porto Alegre: Livraria do Advogado/Esmafé, 2001

RIZZARDO, Arnaldo. Direito de família. Rio de Janeiro: Forense, 2004.

ROCHA, José Virgílio Castelo Branco, O pátrio poder, $2^{\mathrm{a}}$ ed., São Paulo, LEUD, 1978.

RODRIGUES, Silvio. A posição da mulher no direito vigente e no projetado Estudos de Direito Civil, São Paulo, RT, 1979.

. Direito Civil, vol. 6, 27ª ed., São Paulo, Saraiva, 2002.

ROQUE, Sebastião José, Direito de Família, São Paulo, Ícone, 1994.

ROTHENBURG, Walter Claudius. Princípios constitucionais. Porto Alegre: Fabris, 1999.

ROUDINESCO, Elisabeth. A família em desordem. Trad. André Telles. Rio de janeiro: Zahar, 2003.

SANTOS NETO, José Antônio de Paula. Do pátrio poder, São Paulo, RT, 1994.

SILVA, José Afonso da. Curso de direito constitucional positivo. 18. ed. São Paulo: Malheiros, 2000.

SIMÃO, José Fernando. Parentalidade: o duelo DNA $x$ afeto - parte I, in Carta Forense, São Paulo, ed. n. 66, nov/2008, p. 48.

. Parentalidade: o duelo DNA x afeto - parte II, in Carta Forense, São Paulo, ed. n. 67 , dez/2008, p. 16-17.

SINGER, Peter. Practical Ethics, 2nd edition, Cambridge: Cambridge University Press, 1993.

SUANNES, Adauto. As uniões homossexuais e a Lei 9.278/96. COAD, edição especial, out.-nov. 1999.

TEPEDINO, Gustavo. A disciplina jurídica da filiação na perspectiva civilconstitucional. In: PEREIRA, Rodrigo da Cunha (org.). Direito de família contemporâneo. Belo Horizonte: Del Rey, 1997.

. Temas de direito civil. Rio de janeiro: Renovar, 1999:

. O Código Civil, os chamados microssistemas e a Constituição: premissas para uma reforma legislativa. In: Problemas de direito civil-constitucional. Rio de janeiro: Renovar, 2000, p. 547-577.

. Temas de direito civil-constitucional. 2. ed. Rio de Janeiro: Renovar, 2001.

THEODORO JR., Humberto. A onda reformista do Direito Positivo e suas implicações com o princípio da segurança jurídica, in Revista de Doutrina da $4^{a}$ 
Região, n. 14, Porto Alegre, EMAGIS, set. 2006, disponível [on line] in http://www.revistadoutrina.trf4.jus.br/ artigos/ edicao014/_Humberto_Junior.htm [16/02/2009].

VELOSO, Zeno. Direito brasileiro da filiação e da paternidade. São Paulo: Malheiros, 1997., . União estável. Pará: Cejup, 1997. . Homossexualidade e direito. Jornal O Liberal, Belém do Pará, 22 maio 1999, p. 3 .

VENOSA, Sílvio de Salvo. Direito civil: direito de família. 4. ed. São Paulo: Atlas, 2004

VERCELlONE, Paolo. As novas famílias, in Direitos de Família e do Menor inovações e tendências, Del Rey Belo Horizonte, 1992, p. 25-39.

VIANA, Rui Geraldo Camargo. A família, in Rui Geraldo Camargo Viana e Rosa Maria de Andrade Nery (org.), Temas Atuais de Direito Civil na Constituição Federal, São Paulo, RT, 2000.

VILLELA, João Baptista. Liberdade e família, in Revista da Faculdade de Direito da Universidade Federal de Minas Gerais, Belo Horizonte, 1980, v. III, n. 2, p. 0945 .

- Repensando o Direito de Família, in Anais do I Congresso Brasileiro de Direito de Família, IBDFAM, Belo Horizonte, 1999, p. 15-30.

WALD, Arnoldo. Direito de família. 6. ed. São Paulo: Revista dos Tribunais, 1988.

WAMBIER, Teresa Arruda Alvim. Direitos de família e do menor. 3. ed. Belo Horizonte: Del Rey, 1993.

. Investigação de paternidade socioafetiva. In Revista Brasileira de Direito de Família, Porto Alegre: IBDFAM/Síntese, n. 6, p. 50-53, jul. -set. 2000. . Igualdade entre a filiação biológica e socioafetiva. In Revista Brasileira de Direito de Família, Porto Alegre: IBDFAM/Síntese, n. 14, p. 128-163, jul.-set. 2002. 


\section{LEGISLAÇÃO}

Código Civil alemão, disponível [on line] in http://217.160.60.235/BGBL/bgbllf/ bgbl102002s0042.pdf [09-02-2009];

Código Civil argentino, disponível [on line] in http://www.lineajuridica.com/ar/ biblioteca/codigos/defondo/civil/default.html [05-02-2007];

Código Civil chileno, disponível [on line] in http://colegioabogados.org/normas/ codice/codigocivil.html [05-02-2007];

Código Civil espanhol, in Código - Leyes Civiles Generales, Madrid, La Ley, set. 2002, anexo em CD-ROM;

Código Civil francês, disponível [on line] in http://www.legifrance.gouv.fr [09-022009];

Código Civil italiano, disponível [on line] in http://www.jus.unitn.it /Cardozo /Obiter_dictum/codciv/home.html [09-02-2009];

Código Civil porto-riquenho, disponível [on line] in http:// www.lexjuris.com /lexcodigo.htm\#obligaciones [09-02-2009];

Código Civil português, Coimbra, Almedina, 1999;

Código Civil suíço, disponível [on line] in http://www.admin.ch/ch/i/rs/21.html [05-02-2007];

Código Civil uruguaio, disponível [on line] in http:// www.parlamento.gub.uy /htmlstat/pl/codigos/CodigoCivil/2002/cod_civil-indice.htm [09-02-2009];

Código Civil venezuelano, disponível [on line] in http:// www.cajpe.org.pe /rij /bases /legisla/venezuel/consven.htm\#30 [09-02-2009];

Código de Família boliviano, disponível [on line] in http:// www.cajpe.org.pe /rij /bases legisla/bolivia/codfamilia.html [09-02-2009];

Código de Família russo, disponível [on line] in http://zakon.kuban.ru/sayt/index.htm [09-02-2009];

Código da Geórgia, disponível [on line] in http:// www.legis.state.ga.us /legis /2003_04 /gacode/49-5-281.html [09-02-2009];

Convenção sobre as relações pessoais concernentes à criança e ao adolescente, Conselho da Europa, Strasbourg, de 15 de maio de 2003, disponível [on line] in http://conventions.coe.int/Treaty/en/Treaties/Html/192.htm [07-02-2007] ;

Constituição da República Federativa do Brasil, de 05 de outubro de 1988, Diário Oficial da União, Brasília, n. 191-A, 05 out. 1988; 
Decreto 181, de 24 de janeiro de 1890, Cria o casamento civil como uma conseqüência necessária da separação dos poderes, Diário Oficial da União, Brasília, 24 jan. 1890;

Decreto 591, de 06 de julho de 1992, Promulga os Pactos internacionais sobre Direitos Civis e Políticos e sobre Direitos Econômicos, Sociais e Culturais de 1966, Diário Oficial da União, Brasília, 07 jul. 1992;

Decreto 2.172, de 05 de março de 1997, Aprova o Regulamento dos Benefícios da Previdência Social, Diário Oficial da União, Brasília, 06 mar. 1997;

Decreto 17.943-A, de 12 de outubro de 1927, Código de menores, Diário Oficial da União, Brasília, 12 out. 1927;

Decreto 99.710, de 21 de novembro de 1990, Promulga a Convenção sobre os direitos da Criança, Diário Oficial da União-I, Brasília, 22 nov. 1990, p. 22.256 e seguintes;

Decreto legislativo 28, de 14 de setembro de 1990, Aprova a Convenção sobre os direitos da Criança, Diário Ofícial da União, Brasília, 14 set. 1990;

Decreto-lei 3.200, de 19 de abril de 1941, Dispõe sobre a organização e proteção da família, Diário Oficial da União, Brasília, 19 abr. 1941;

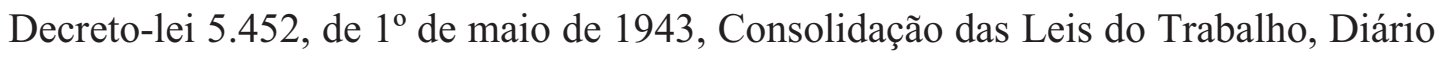
Oficial da União, Brasília, 09 de maio de 1943;

Decreto-lei 9.701, de 3 de setembro de 1946, Dispõe sobre guarda de filhos no desquite judicial, Diário Oficial da União, Brasília, 03 set. 1946;

Lei 3.071, de $1^{\circ}$ de janeiro de 1916, Código Civil brasileiro, Diário Oficial da União, Brasília, $1^{\circ}$ jan. 1916;

Lei 4.121, de 27 de agosto de 1962, Estatuto da Mulher Casada, Diário Oficial da União, Brasília, 03 set. 1962;

Lei 5.582, de 16 de junho de 1970, Altera o artigo 16 do Decreto-lei 3.200/41, Diário Oficial da União, Brasília, 16 jun. 1970;

Lei 5.869, de 11 de janeiro de 1973, Código de Processo Civil, Diário Oficial da União, Brasília, 11 jan. 1973;

Lei 6.515, de 26 de dezembro de 1977, Lei do Divórcio, Diário Oficial da União, 27 dez. 1977;

Lei 6.697, de 19 de outubro de 1979, Código de Menores, Diário Oficial da União, Brasília, 19 out. 1979; 
Lei 8.069, de 13 de julho de 1990, Estatuto da Criança e do Adolescente, Diário Oficial da União, Brasília, 13 jul. 1990;

Lei 9.278, de 10 de maio de 1996, Regula o parágrafo $3^{\circ}$ do artigo 226 da Constituição Federal, Diário Oficial da União, Brasília, 10 de maio de 1996;

Lei 10.406, de 10 de janeiro de 2002, Código Civil Brasileiro, Diário Oficial da União, Brasília, 10 jan. 2002;

Lei 11.340, de 07 de agosto de 2006, Diário Oficial da União, 08 de agosto de 2006;

ONU, Declaração de Genebra sobre os Direitos da Criança, 1924; , Carta da ONU, 26 jun. 1945; , Declaração Universal dos Direitos Humanos, 10 dez. 1948; , Declaração Universal dos Direitos da Criança, 20 nov. 1959; , Pacto internacional sobre Direitos Civis e Políticos, 1966; , Pacto internacional sobre Direitos Econômicos, Sociais e Culturais, 1966; , Convenção Internacional sobre os Direitos da Criança, 20 nov. 1989;

UNESCO, Declaração Universal dos Direitos dos Animais, 27 jan. 1978; 


\section{RESUMO}

\section{NOVOS VÍNCULOS JURÍDICOS NAS RELAÇÕES DE FAMÍLIA}

A família atual tem sofrido grandes transformações resultantes da mutação social, com graves reflexos nos direitos e deveres dos seus membros, porque a forma de sua constituição, outrora baseada no casamento indissolúvel e na prole então chamada "legítima", cedeu espaço a inúmeras outras, decorrentes de toda uma sorte de convivências alheias ao casamento e da progressiva equalização de direitos entre homem e mulher e entre todos os filhos.

O objetivo deste trabalho é o estudo dos novos vínculos jurídicos considerados como legítimos formadores da família contemporânea, dentro da ótica do afeto como elo essencial para a sobrevivência de tal núcleo.

Nesse caminho, passaremos pelo estudo da família, enfocando sua formação e extinção, e da filiação, bem como dos princípios de direito intimamente ligados ao tema, como o da dignidade da pessoa humana, da solidariedade, da afetividade, da igualdade, da liberdade, da convivência familiar e do melhor interesse da criança, como meio para o alcance das conclusões sobre esse tema, em contribuição original à ciência jurídica brasileira. 


\section{ABSTRACT \\ NEW LEGAL LINKS IN FAMILY RELATIONSHIPS}

The current family has suffered big chances as results of the social mutation, with serious consequences on the rights and duties of its members. That has occurred because, in the past, its constitution, which was based in an insoluble marriage and in the children who were then considered "legitimate", opened space to countless other families, which were constituted due to an assortment of relationship out of the marriage and out of the progressive equalization of the rights between the couple and among all the children.

The aim of this work is to study the new legal links considered as legitimate builder of the contemporary family, under the affection viewpoint as an essential link for its survival.

In this way, we are going to study the family, focusing its formation and extinction, and its children as well as the principles of the rights deeply connected to the theme, as the dignity of the human being, the solidarity, the affectivity, the equality, the liberty, the family relationship, and the best interest of the child, as a means to achieve the conclusions of this theme, contributing with the Brazilian legal science. 


\section{RÉSUMÉ}

DES NOUVEAUX LIENS JURIDIQUES DANS LES RELATIONS DE FAMILLE

La famille actuelle a subi des grosses transformations a cause des changements sociaux, avec des très graves consequences sur les droits et les devoirs des ses membres car sa formation qui était ailleurs fondée sur le mariage indissolube et des enfants nés y dedans a donné sa place a des autres types de vie en comum hors de mariage et l'égalité progressive des droits des hommes, des femmes et des tous les enfants y inclus les naturels.

Le but de ce travail est l'étude des nouveaux liens juridiques considerés comme des vrais formations de la famille actuelle sous un point de vue de la tendresse qui se montre comme une liaison essentielle pour la survivence de ce noyau.

Ainsi, nous étudierons la famille en soulignant sa formation et extintion, la filiation et les príncipes du droit les plus proches de ce sujet tels quels la dignité de la personne, la solidarieté, l'affectivité, l'égalité, la liberté, le maintien à domicile de ses membres dans le plus haut interêt des enfants pour arriver aux conclusions sur ce sujet et de cette façon présenter une contribution originale à la science juridique brésilienne. 